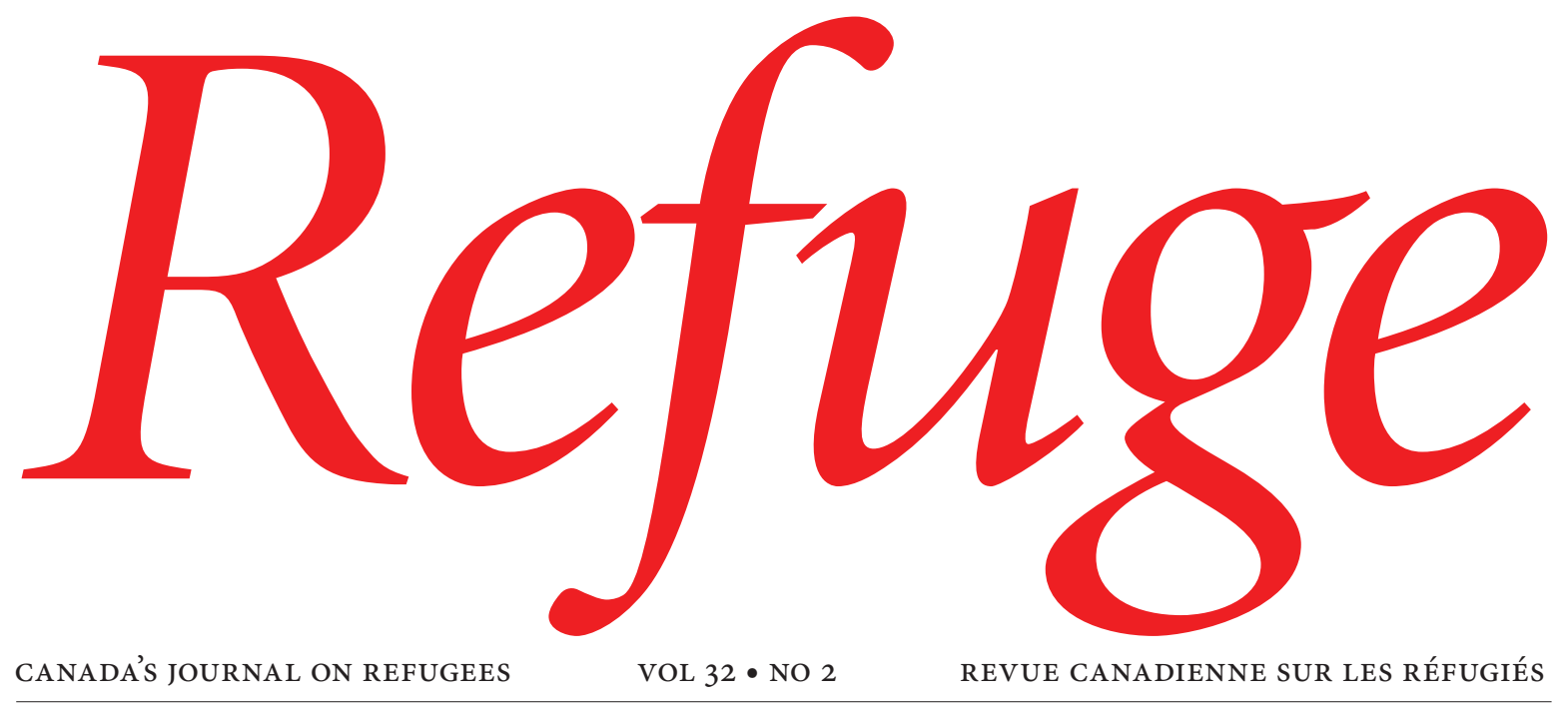

\title{
The Indochinese Refugee Movement and the Launch of Canada's Private Sponsorship Program
}

Introduction

MICHAEL J. MOLLOY AND JAMES C. SIMEON

The Stories They Carried:

Reflections of Vietnamese-Canadians 40 Years after That War

PRISCILLA KOH

A Case Study of the Vietnamese in Toronto: Contesting Representations of the Vietnamese in Canadian Social Work Literature

ANH NGO

The Vietnamese Refugee Crisis of the 1970 s and 1980s: A Retrospective View from NGO Resettlement Workers ANNA N. VU AND VIC SATZEWICH
The Indochinese Refugee Movement and the Subsequent Evolution of UNHCR and Canadian Resettlement Selection Policies and Practices MICHAEL CASASOLA

Inside/Outside the Circle:

From the Indochinese Designated Class to Contemporary Group Processing ROBERT C. BATARSEH

Private Sponsorship: Complementary or Conflicting Interests? SHAUNA LABMAN

The Indochinese Refugee Movement: An Exploratory Case Study of the Windsor Experience GIOVANNA ROMA 


\title{
Refuge
}

\section{Canada's Journal on Refugees \\ Revue canadienne sur les réfugiés}

Vol. 32, No. 2

Centre for Refugee Studies, Room 844, Kaneff Tower, York University

4700 Keele Street, Toronto, Ontario, Canada M3J 1P3

E-mail: refuge@yorku.ca

Website: http://www.yorku.ca/refuge

\author{
Editor-in-Chief \\ Christina Clark-Kazak
}

Guest Editors

Michael J. Molloy and James C. Simeon

Managing Editor Johanna Reynolds

Book Review Editor Dianna Shandy

Editorial Advisory Board

Sharryn Aiken, Queen's University

Laura Bisaillon, University of Toronto Scarborough

Megan Bradley, McGill University

François Crépeau, McGill University

Jeff Crisp, Refugees International

Judith Kumin, University of New Hampshire, Manchester

Susan McGrath, York University

Volker Türk, UNHCR

Madine Vanderplaat, Saint Mary's University

Founded in 1981, Refuge is an interdisciplinary journal published by the Centre for Refugee Studies, York University. The journal aims to provide a forum for discussion and critical reflection on refugee and forced migration issues.

Refuge invites contributions from researchers, practitioners, and policy makers with national, international, or comparative perspectives. Special, thematic issues address the broad scope of the journal's mandate, featuring articles and reports, shorter commentaries, and book reviews. All submissions to Refuge are subject to double-blinded peer review. Articles are accepted in either English or French.

Refuge is a non-profit, independent periodical funded by the Social Sciences and Humanities Research Council of Canada and supported by the membership of the Canadian Association for Refugee Studies (CARFMs). The views expressed in Refuge do not necessarily reflect those of its funders or editors.

Refuge is indexed and abstracted in the Index to Canadian Legal Literature, Pais International, Sociological Abstracts, the International Bibliography of the Social Sciences, and Canadian Business and Current Affairs. In accordance with the journal's open access policy, the full text of articles published in Refuge is also available online through our website, www.yorku.ca/refuge.

ISSN (online): 1920-7336 


\section{Contents}

\section{INTRODUCTION}

The Indochinese Refugee Movement and the Launch of Canada's Private Sponsorship Program MICHAEL J. MOLLOY AND JAMES C. SIMEON . . . . . . . . 3

\section{ARTICLES}

The Stories They Carried: Reflections of Vietnamese-

Canadians 40 Years after That War PRISCILLA КОН $\ldots \ldots \ldots \ldots \ldots \ldots \ldots \ldots \ldots \ldots$

A Case Study of the Vietnamese in Toronto:

Contesting Representations of the Vietnamese in

Canadian Social Work Literature ANH NGO . 20

The Vietnamese Refugee Crisis of the 1970s and 1980s: A Retrospective View from NGo Resettlement Workers ANNA N. VU AND VIC SATZEWICH $\ldots \ldots \ldots \ldots \ldots \ldots \ldots$

The Indochinese Refugee Movement and the Subsequent Evolution of UNHCR and Canadian Resettlement

Selection Policies and Practices

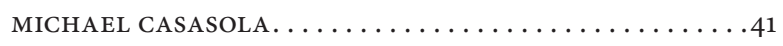

Inside/Outside the Circle: From the Indochinese Designated Class to Contemporary Group Processing RoBERT C. BATARSEH..................... 54

Private Sponsorship: Complementary or Conflicting Interests?

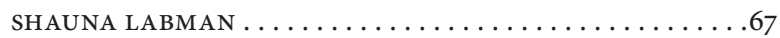

The Indochinese Refugee Movement:

An Exploratory Case Study of the Windsor Experience GIOVANNA ROMA $\ldots \ldots \ldots \ldots \ldots \ldots \ldots \ldots \ldots \ldots \ldots$

\section{BOOK REVIEWS}

From the Land of Shadows: War, Revolution and the Making of the Cambodian Diaspora

by Khatharya Um Southeast Asian Migration: People on the Move in Search of Work, Refuge and Belonging edited by Khatharya Um and Sofia Gaspar

VINCENT K. HER . . . . . . . . . . . . . . . . . . 90

Migration by Boat: Discourses of Trauma, Exclusion and Survival

edited by Lynda Mannik

DIANA M. DEAN. . . . . . . . . . . . . . 92

Unsettled: Cambodian Refugees in the New York City Hyperghetto

by Eric Tang

JUDY LEDGERWOOD

Across the Seas: Australia's Response to Refugees-

A History

by Klaus Neumann

ANTJE MISSBACH .95

Real Queer? Sexual Orientation and Gender Identity

Refugees in the Canadian Refugee Apparatus

by David A. B. Murray

AMAR WAHAB ...

Navigating a River by Its Bends: A Comparison of

Cambodian Remigration

by Gea Wijers

ALEXANDRA KENT 98 


\title{
Introduction
}

\section{The Indochinese Refugee Movement and the Launch of Canada's Private Sponsorship Program}

\author{
MICHAEL J. MOLLOY AND JAMES C. SIMEON
}

$\mathrm{T}$ This special issue of Refuge comes as Canada is receiving a second tranche of Syrian refugees processed in Beirut in May 2016. They are admitted as governmentassisted refugees (GARS), privately sponsored refugees (PSRS), and Blended Visa Officer-Referred (BVOR), a category where the UNHCR selects the refugees for resettlement and the Canadian government and private sponsors share the costs and commitment for settlement of the refugees in Canada. ${ }^{1}$ The historical precedent for Canada's Syrian program took place forty years ago when 60,000 refugees from Vietnam, Cambodia, and Laos were admitted. These included 25,978 GARs, and 32,281 under the newly launched private sponsorship program. An additional 1,790 were sponsored by relatives in Canada. ${ }^{2}$

It is not entirely serendipitous that, as shocking images from the Mediterranean motivated Canadians to press their government to react to the needs of the Syrians in 2015 and 2016, Canada's response to the Indochinese refugees in 1979 and 1980 was cited as a model to emulate. ${ }^{3}$ In the past three years, a series of academic and public events have focused on the movement of refugees from former Indochina, including events across the country in 2015 that commemorated the 4oth anniversary of the fall of Saigon and the start of the movement of Indochinese refugees to Canada. In addition, Vietnamese, Laotian, and Cambodian groups organized an event in Ottawa recognizing the anniversary of the awarding of the Nansen Medal to the people of Canada. The release of two acclaimed novels, Vincent Lam's The Headmasters Wager and Kim Thuy's $R u$ brought the Indochinese refugee movement into sharp focus for the first time in decades. ${ }^{4}$

The guest editors of this special issue met for the first time in 2012. Mike Molloy was giving a series of lectures at Ontario universities on the occasion of the 4oth anniversary of the Ugandan Asian refugee movement of 1972. His host at York University's Centre for Refugee Studies was the acting director, James C. Simeon. When Simeon learned that Molloy and a group of colleagues from the Canadian Immigration Historical Society (CIHS) ${ }^{5}$ were working on a book-Running on Empty: Canada and the Indochinese Refugee Movement 1975-1980 (McGill-Queen's University Press, Spring 2017) - he suggested that CRS and CIHs host a conference on the refugees from former Indochina. The conference took place in November 2013 at York University and heard the testimonies of Vietnamese, Sino-Vietnamese, Cambodian, and Laotian refugees. Individually and collectively, these speakers reflected on the processes of becoming refugees, their arrivals in Canada, their first encounters with sponsors, and their long-term adaptation to life in Canada. The conference also included panels of former visa officers, media representatives, political leaders, community activists, and coordinators as well as academics.

Preparation for the 2013 conference revealed a surprising lack of academic attention to Canada's Indochinese refugee movement, given its magnitude, its impact, ${ }^{6}$ and 
the enormous barriers that confronted refugees in adapting to and integrating into Canada. W. Courtland Robinson's Terms of Refuge ${ }^{7}$ provides a thorough examination of the refugee crisis and the international response but touches on the Canadian effort only briefly. Howard Adelman's Canada and the Indochinese Refugees ${ }^{8}$ remains a relevant examination of the policy choices of the government and how Canadian civil society responded but contains little on the overseas operation. Having been published in 1982, the book came too early to describe the challenges that newcomers faced in adapting to a country so vastly different from their own. Lawrence Lam's Vietnamese-Chinese Refugees in Montreal: Long-Term Settlement (1985)9 makes a useful contribution in this regard, as does his From Being Uprooted to Surviving: Resettlement of Vietnamese-Chinese "Boat People" in Montreal, 19801990 (1996). ${ }^{10}$ And Doreen Indra's "Southeast Asian Refugee Resettlement: A Research Bibliography," (1984) ${ }^{11}$ makes a useful contribution in listing the most helpful sources available.

A decade after the refugees arrived there was a spate of studies on how the refugees had fared in different parts of Canada. Anh Ngo, one of the authors in this special issue, identified 85 scholarly works in a search of social sciences websites. ${ }^{12}$ Among these, Morton Beiser's Strangers at the Gate: The "Boat People's" First Ten Years in Canada ${ }^{13}$ is perhaps the strongest, but it focuses exclusively on British Columbia. Ten Years Later: Indochinese Communities in Canada ${ }^{14}$ and Uprooting, Loss and Adaptation: The Resettlement of Indochinese Refugees in Canada ${ }^{15}$ provide insights into Vietnamese, Sino-Vietnamese, Cambodian and Laotian communities in different parts of the country. There is no overarching study that covers the experience of these refugees Canada-wide, and little academic work seems to have been done since the 1990 .

The 4oth anniversary of the fall of Saigon in April 2015 was marked by events across the country to recall the loss and suffering of the refugee experiences, acknowledge the welcome they received in Canada, and celebrate the rebuilding of lives here. The anniversary provided an occasion for the proclamation by Parliament on 30 April 2015 of a bill championed by Senator Thanh Hai Ngo designating 30 April as Journey to Freedom Day, despite opposition of the Vietnamese government and parts of the Canadian Vietnamese community. ${ }^{16}$

In June 2016, the Vietnamese Canadian Federation, Cambodian Association of the Ottawa Valley, and the Laotian Association of the Ottawa Valley came together to organize an event in Ottawa to celebrate the 3oth anniversary of the awarding of the Nansen Medal to the people of Canada for their efforts on behalf of refugees. Individuals from these three organizations are collaborating with Carleton
University, the Canadian Museum of History, the Canadian Museum Association, Pier 21, and CiHs, among others, on an ambitious project called "Hearts of Freedom" to collect artifacts and 200 oral histories and produce a documentary and public history book. Involvement of the Canadian Museum of History has positioned community leaders to argue successfully that, when the Canadian History Gallery is opened next year, the arrival of the "boat people" and other Indochinese refugees will be part of the exhibit. Complementary initiatives are underway or contemplated in Montreal and Toronto.

This special issue of Refuge covers three broad areas dealing with the Indochinese refugee movement in Canada: the human experiences and memories of the refugees that led to their flight from their homelands and their ongoing settlement within Canada; Canadian refugee policies that shaped the Indochinese refugee movement in specific ways and how they have subsequently evolved; and how the mayor of one Canadian city mobilized his fellow citizens to receive Indochinese refugees almost two years before the rest of Canada.

Priscilla Koh's article examines the recollections of six Vietnamese Canadians from different regions of Vietnam. Their accounts reveal a rich diversity of experiences covering efforts to accommodate to the new Communist regime; the conditions that triggered decisions to escape and the consequent splitting of families; the boat experiences-smooth sailing and terrifying; life in the refugee camps where robbery, rape and murder were not uncommon but where kindness and mutual assistance were part of the experience as well; the decision to come to Canada and the post-arrival struggles. In some cases those interviewed managed to find employment, obtain university degrees, and pursue professional careers. Others were not so fortunate and struggled for years. The value of studies like Koh's is that they remind us of the human experiences of fleeing oppression and seeking asylum and that within each population displacement there are myriad individual experiences.

Anh Ngo's article delves deeper into the human experience with an examination of the barriers, divisions, and tensions within the Vietnamese community in Toronto. Sources of discord include intergroup differences stemming from war and displacement, mediated identities of region, class, and the different waves of arrivals. She examines discourses about the Vietnamese as "legitimate," "productive," and "inassimilable" refugees before discussing the results of a study involving focus groups and in-depth interviews delving into the frictions that exist within the community. Ngo highlights the problems faced by refugees from former North Vietnam and a tendency within the community to disparage later arrivals as "economic" refugees as opposed to the "genuine refugees" of the earlier arrivals. Her study
(C) Author(s), 2016. This open-access work is licensed under a Creative Commons Attribution-NonCommercial 4.0 International license.
Cette oeuvre en libre accès fait l'object d'une licence Creative Commons Attribution-NonCommercial 4.0 International. 
demonstrates the heterogeneity-and at times divisionswithin populations that are too often outwardly perceived in group terms.

In the next paper Anna N. Vu and Vic Satzewich provide insights into the roles and perceptions of NGO settlement workers in refugee camps in Southeast Asia in the late 1970 s and early $1980 \mathrm{os}$. On the basis of interviews and information gathered from 14 former settlement workers, Satzewich and $\mathrm{Vu}$ examined the role of these "meso-level" workers in assisting refugees to navigate the selection systems of Western countries of resettlement. According to settlement workers interviewed for the study, refugees presented their situations to national resettlement officials in ways intended to maximize their chances of acceptance, based in part on rumours about which refugees were successful and why, as well as advice, not always reliable, from friends and families already in resettlement countries. The authors conclude that the experience of working with refugees had reciprocal benefits for workers and refugees alike and that the workers were profoundly changed by the experience.

The three next articles take the Indochinese refugee program as a point of departure and then follow three distinct but complementary vectors to the present. Michael Casasola examines how Canadian and UNHCR resettlement policies were affected by the Indochinese refugee experience and how they have alternatively diverged and converged over the succeeding decades. Robert C. Batarseh looks at the Indochinese Designated Class Regulation the government implemented on the eve of the 197980 resettlement program, how it was later modified to bring it into compliance with the Comprehensive Plan of Action, and how it foreshadowed current UNHCR and Canadian group processing practices. Shauna Labman discusses how the foundational "additionality" principle, which held that privately sponsored refugees would be admitted over and above the government's refugee resettlement commitments, has been eroded over the years.

Michael Casasola's article characterizes the resettlement of Indochinese refugees as a defining movement for refugee resettlement internationally and for Canada. Almost two million Indochinese were resettled between 1975 and 1997 from countries of first asylum and through orderly departure programs. Two innovations shaped the Canadian response: the Indochinese Designated Class that simplified the selection process, and the private refugee sponsorship program, which engaged tens of thousands of Canadians in helping new arrivals to adjust and greatly increased the number of refugees Canada was willing to resettle. Casasola describes the evolution of UNHCR's post-Indochinese resettlement policy and the institutions (e.g., the Working Group on Resettlement and Annual Tripartite Consultations on
Resettlement, the Global Consultations, etc.) and the policies and practices that emerged to reinforce UNHCR leadership. He identifies the Canadian role helping to shape UNHCR policies and initiatives and traces parallel developments in Canada, including the fundamental changes implemented through the Immigration and Refugee Protection Act (IRPA).

Robert C. Batarseh's contribution covers the same period, but with a focus on definitions and the evolution of contemporary group-processing practices employed in partnership by UNHCR, Canada, and other resettlement countries. He describes Canadian experimentation with alternatives to the UN Convention Refugee definition going back to the Oppressed Minority Policy of the early 1970s, the three designated classes that emerged from the 1976 Immigration Act and successor categories rooted in the IRPA. Batarseh describes Canada's role in revitalizing resettlement within UNHCR in the early 20oos. Perhaps the most interesting part of the this article is his description of how concerns about pull factors, fraud, and security along with resource constraints has led UNHCR and the resettlement countries to a resettlement model that seeks out homogenous and self-contained groups of refugees that can be efficiently group processed, skipping time-consuming individual refugees' status determination.

While Batarseh follows the impact of the definitional innovations that Canada pioneered in the Indochinese program, Shauna Labman examines how the Canadian private sponsorship program, launched just as the Indochinese exodus reached crisis proportion, has fared over the past 40 years. The viability of the sponsorship program is not merely a parochial concern: Canadian sponsors have provided quality, durable solutions for an estimated 225,000 refugees since the program was launched in 1978. Conceived as a complementary partnership, sponsorship, according to Labman, plays out as a "tug-of-war between the conflicting interests of government and sponsors over selection control and numbers." When the program was first marketed to the churches and the voluntary sector, the notion of "additionality" was central: privately sponsored refugees would be admitted over and above government refugee targets and, therefore, would increase the overall Canadian contribution. In addition, sponsors would be free to choose their refugees by name or group. Labman documents a series of experiments where the government and sponsors payed varying proportions of the first-year settlement costs. She then explores the erosion of the bedrock additionality principle, particularly under the Harper government, including blurring the distinction between the two streams and the imposition of more complicated rules and procedures. Particularly troubling for sponsors was a pattern of ministers announcing international commitments with heavy
(C) Author(s), 2016. This open-access work is licensed under a

Creative Commons Attribution-NonCommercial 4.0 International license.
Cette oeuvre en libre accès fait l'object d'une licence Creative Commons Attribution-NonCommercial 4.0 International. 
implications for the sponsors without prior consultation. How much of this was driven by ideology and how much by severe budget constraints and soaring settlement costs is unclear, but given the recent change in government, this article is most timely.

In the final article, Giovanna Roma describes how a few pieces of scattered documentation enabled her to reconstruct a forgotten piece of important Canadian refugee history. The evidence reveals that in the summer of 1977, two full years before the establishment of Operation Lifeline and Project 4000, the mayor of Windsor, Ontario, established a committee of civic leaders and activist clergy to sponsor Vietnamese "boat people." Before there was even a formal private sponsorship program, the mayor's committee had reached out to the visa office in Singapore and was receiving refugees, including from the famous Hai Hong. This local initiative had a surprisingly far-flung impact.

This special issue of Refuge was conceived as a vehicle for stimulating scholarship about the Indochinese refugee movement and its consequences. It is important to recall that when Saigon fell in 1975, Canada's refugee resettlement programs had been open to non-Europeans for only five years and the intake of refugees from non-traditional sources 228 Tibetans, 100 Chinese from Hong Kong, approximately 7,000 Asians expelled from Uganda ${ }^{17}$ (virtually all of the last were fluent English speakers) - was rather modest. The decision to admit 50,000 refugees fleeing by sea, and overland refugees from camps in Thailand, few of whom had ties in Canada, was and is remarkable. The rough and ready assessment of these refugees' capacities in English and French done by the visa officers in Southeast Asia, based simply on whether an interpreter had to be used during interview, gives a hint of the challenge these newcomers would face: English speakers 4.3 per cent; French speakers 2.5 per cent; English and French 1.4 per cent; neither 91.8 per cent. ${ }^{18}$

Following the Indochinese, refugees from non-European sources would become the rule rather than the exception, so we would argue that the experiences of this large and highly varied movement has lessons to teach us far beyond the impressions gathered at the end of the first decade or so, both about the adaptation experiences of the refugees and the efficatcy of Canada's dual-track resettlement system.

One frequently hears that the private sponsorship program is superior to the government program. ${ }^{19}$ By the end of 1980 , the task force set up to manage the admission of the 50 , then 60,000 refugees was receiving anecdotal indications to the contrary-the monthly allowance the governmentassisted refugees received from the government and the independence (and privacy) it brought was highly valued and envied by the sponsored refugees. This was noted a decade later in studies by Yuen-Fong Woon and Beiser. More work could be done on this issue. ${ }^{20}$

In addition, there has been little attention to the fact that a very high proportion of refugees were Sino-Vietnamese (30 per cent of the 60,00o identified with a Chinese mother tongue $^{21}$ ) and it would be fascinating to know, four decades later, the extent to which they maintain a distinct identity or have perhaps assimilated in the larger Canadian Chinese community.

The locations of the private sponsors and deliberate destining decisions by the Immigration Department between 1979 and 1980 ensured that the refugees who came were spread across the country as never before, including small towns and rural communities. As early as 1980 officials were reporting a significant degree of secondary migration from smaller towns and rural areas in the direction of Canada's largest cities. This would continue. ${ }^{22}$ However not all moved on, and in an era when smaller Canadian towns and communities are desperate to attract and retain population, it would be fascinating to understand the reasons and factors that caused some to remain in the smaller communities.

It would be interesting to document how each of the Indochinese refugee communities has organized itself within Canada. As we note above, and some of the contributors have done in their articles, these communities have been very active in the celebrations that have marked the 4oth anniversary of the fall of Saigon and mobilizing to get official recognition of 30 April as the annual day in Canada to mark the Journey to Freedom Day for all those who have sought asylum in Canada.

It is remarkable to note that there has been as little scholarship on the Indochinese refugee movement, the single largest and perhaps the most successful resettlement program in Canadian history. This special issue of Refuge, we hope, will serve as a primer for further research on this most fascinating humanitarian effort on the part of both the people of Canada and all levels of government in welcoming some 60,000 Indochinese refugees in such a short period to their country. A public policy initiative of this magnitude required bold political leadership, a dedicated public service that was willing to brave harsh and even hostile conditions at times, and a galvanized Canadian public that wanted to assist. It was a remarkable period that reminds us of what we are capable of in the humanitarian field when we are committed to assist those in need of refuge from persecution.

The Indochinese refugee movement has come to serve as a model for how to respond to our present-day refugee crisis that is unfolding in the Mediterranean Sea and in other parts of the world at unprecedented levels. Now, the new "boat people," predominantly Syria refugees, are seeking
(C) Author(s), 2016. This open-access work is licensed under a Creative Commons Attribution-NonCommercial 4.0 International license.
Cette oeuvre en libre accès fait l'object d'une licence Creative Commons Attribution-NonCommercial 4.0 International. 
refuge from protracted armed conflict that has resulted in some 470,00o killed and over 4.2 million displaced. ${ }^{23}$

Our hope is that this collection will demonstrate how the Indochinese refugee movement has left its indelible stamp on Canadian society. But, equally, it has afforded Canada the opportunity to build on what has come before in resettlement programs. We hope that this special issue of Refuge will shine further light and provide additional understanding for the key elements and aspects of the Indochinese refugee movement that will prove helpful for forging future humanitarian refugee resettlement programs in Canada and abroad.

\section{Notes}

1 Jacquie Miller, "By the Numbers: Privately-Sponsored versus Government-Sponsored Refugees," Ottawa Citizen, 26 February 2016, http://ottawacitizen.com/news/local-news/ by-the-numbers-privately-sponsored-and-governmentsponsored-refugees. See the Government of Canada website at Blended Visa Officer-Referred Program: Sponsoring Refugees, http://www.cic.gc.ca/english/refugees/sponsor/ vor.asp. See also Michaela Hynie and Jennifer Hyndman, "From Newcomer to Canadian: Making Refugee Integration Work; Human Settlement Must Involve Creating the Right Conditions for Refugees to Be Integrated into Their New Communities," Policy Options Politique, 17 May 2016, http://policyoptions.irpp.org/magazines/may-2016/fromnewcomer-to-canadian-making-refugee-integrationwork/.

2 Employment and Immigration Canada, Indochinese Refugees: The Canadian Response, 1979 and 1980 (Ottawa: Minister of Supply and Services Canada, 1982), 20.

3 Peter Goodspeed, Atkinson Series, "Can Canada Duplicate Its Boat People Rescue with the Syrian Refugees?" thestar.com, 26 September 2014, https:/www.thestar.com/ news/atkinsonseries/2014/o9/26/can_canada_duplicate_ its_boat_people_rescue_with_syrian_refugees.html. Judy Trinh, "Vietnamese Boat People of More Than Three Decades Ago Now Thriving, Proud Canadians; Drowned Syrian Boy 'Could Have Been You,' Sino-Vietnamese Mom Tells CBC Ottawa Reporter Judy Trinh,” свCNews, Ottawa, 11 September 2015, http://www.cbc.ca/news/ canada/ottawa/vietnamese-boat-people-of-more-than3-decades-ago-now-thriving-proud-canadians-1.3223505; New America Media: Immigration, "Déjà Vu: Syrian and Indochinese Refugee Movements," accessed 14 June 2016, http://newamericamedia.org/2016/o2/deja-vu-syrian-andindochinese-refugee-movements.php. See the Canadian Immigration Historical Society, CIHs Bulletin 73-A, April 2015, "The Indochinese Movement: Fortieth Anniversary," http://cihs-shic.ca/wp-content/uploads/2015/05/bulletin73-a-2.pdf. It is also worth noting that this occurred in the midst of the 2015 federal election campaign and had a dramatic impact on the outcome of the election. For instance, see John Iverson, "Migrant Crisis Is Suddenly the Biggest Issue in the Election Campaign-and Harper Is on the High Wire," National Post, 3 September 2015, http://news.nationalpost.com/news/canada/john-ivisonmigrant-crisis-suddenly-the-biggest-issue-in-the-election-campaign-and-harpers-on-the-high-wire. "Election Primer: Four Things to Know before You Vote," Globe and Mail, 16 October 2015, http://www.theglobeandmail. $\mathrm{com} /$ news/politics/canada-and-the-refugee-crisis-fourthings-to-know-before-youvote/article26363975/. For the federal election results, see Elections Canada, 19 October 2015, Election Results, http://enr.elections.ca/National. aspx?lang=e.

4 See, for instance, the Canadian Immigration Historical Society, "Fortieth Anniversary of the Indochinese Refugee Movement in Canada," http://cihs-shic.ca/indochina/.

5 www.cihs.shic.ca.

6 Canada's Vietnamese community today numbers some 300,000 .

7 W. Courtland Robinson, Terms of Refuge: The Indochinese Exodus and the International Response (London: Zed Books, 1998).

8 Howard Adelman, Canada and the Indochinese Refugees (Regina: L. A. Weigl Educational Associates, 1982).

9 Lawrence Lam, Vietnamese Chinese Refugees in Montreal: Long-Term Settlement (Downsview, on: University of Toronto-York University Joint Centre on Modern East Asia Canada and the Pacific Programme, 1985).

10 Lawrence Lam, From Being Uprooted to Surviving: Resettlement of Vietnamese-Chinese "Boat People" in Montreal, 1980-1990 (Toronto: York Lanes, 1996).

11 Doreen Indra, "Southeast Asian Resettlement in Canada: A Research Bibliography” (Ottawa: Canadian Asian Studies Association, Carleton University, 1984), Forced Migration Online Digital Library, repository.forcedmigration. org/pdf/?pid=fmo:2166.

12 Ngo consulted Social Services Abstracts, Sociological Abstracts, Pyschinfo, and Applied Social Sciences Index and Abstracts. Articles in these sources cover the period 1970 to 2016.

13 Morton Bieser, Strangers at the Gate: The "Boat People's" First Ten Years in Canada (Toronto: University of Toronto Press, Scholarly Publishing Division, 1999).

14 Kwok B. Chan, Louis-Jacques Dorais, and Doreen Marie Indra, eds., Ten Years Later: Indochinese Communities in Canada (Montreal: Canadian Asian Studies Association, 1988).

15 Kwok B. Chan and Doreen Marie Indra, eds., Uprooting, Loss and Adaptation: The Resettlement of Indochinese Refugees in Canada (Ottawa: Canadian Public Health Association, 1987).

16 Journey to Freedom Day Act, S.C. 2015, c. 14, Assented to 2015-04-23, http://laws-lois.justice.gc.ca/eng/acts/J-0.9/ page-1.html. See also Office of the Honourable Senator
(C) Author(s), 2016. This open-access work is licensed under a Creative Commons Attribution-NonCommercial 4.0 International license.
Cette oeuvre en libre accès fait l'object d'une licence Creative Commons Attribution-NonCommercial 4.0 International. 
Thanh Hai Ngo, "Journey to Freedom Day Act," http:// senatorngo.ca/wp-content/uploads/2015/o6/Full-Binder_ Journey-to-Freedom-Day-Act.pdf.

17 Employment and Immigration Canada, Indochinese Refugees, 32.

18 Ibid., 24.

19 "Why So Many Canadians Privately Sponsor Syrian Refugees," Economist, 3 March 2016, http://www.economist.com/blogs/economist-explains/2016/o3/economistexplains-2. "Research indicates that privately-sponsored refugees become more successful than their governmentsponsored counterparts or asylum seekers who arrive under their own steam, perhaps because they have a support group from the moment they arrive."

20 Yuen-Fong Woon in Chan and Indra, Ten Years Later, 141; and Bieser, Strangers at the Gate, 121.

21 Employment and Immigration Canada, Indochinese Refugees, 23.

22 J. D. Love, deputy minister/chairman, Employment and Immigration Canada, "Indochinese Refugee Program: 1980-81," 4 September 1980, file 8700-1 pt. 3, vol. 1836, RG 76, Library and Archives Canada. See also Louis-Jacques Dorais, The Cambodians, Laotians and Vietnamese in
Canada, Canada's Ethnic Group Series booklet no. 28 (Ottawa: Canadian Historical Association, 200o), 11.

23 UNHCr Syria, Reporting Team Damascus, Syria, Protecting and Supporting the Displaced in Syria: UNHCR Syria End of Year Report 2015, www.unhcr.org/56cad5a99.pdf. See also Anne Barnard, "Death Toll from the War in Syria Now 470,000, Group Finds," New York Times, 11 February 2016, http://www.nytimes.com/2016/o2/12/world/middleeast/ death-toll-from-war-in-syria-now-4700oo-group-finds .html.

Michael J. Molloy is president of the Canadian Immigration Historical Society and an honorary senior fellow at the University of Ottawa's Graduate School of Public and International Affairs. He can be contacted at joandmikeca@yahoo .com.

James C. Simeon is associate professor in the School of Public Policy and Administration, Faculty of Liberal Arts and Professional Studies at York University. He can be contacted at jcsimeon@yorku.ca.
(C) Author(s), 2016. This open-access work is licensed under a Creative Commons Attribution-NonCommercial 4.0 International license.
Cette oeuvre en libre accès fait l'object d'une licence Creative Commons Attribution-NonCommercial 4.0 International. 


\title{
The Stories They Carried: Reflections of Vietnamese-Canadians 40 Years after That War
}

\author{
PRISCILLA KOH
}

\section{Abstract}

This article explores the narratives of former refugees from Vietnam who resettled in Canada. Each of these stories highlights the profound dilemmas, motivations, and experiences of Vietnamese refugees. Collectively, they demonstrate the remarkable resilience of this community, and their determination to survive and remake themselves in Canada. The discussion illuminates the diversity and complexity of my respondents' senses of belonging, homes, and homelands, and how such notions and ties are continually evolving. The research aims to contribute to the postwarl refugee discourse, and to move the field beyond the parameter of the war and exodus from Vietnam, in order to study Vietnamese in all their complexities-in a new locale.

\section{Résumé}

Cet article explore les discours des anciens réfugiés du Vietnam qui se sont réinstallés au Canada. Chacune de ces histoires souligne les dilemmes profonds, les motivations et les expériences des réfugiés vietnamiens. Collectivement, elles démontrent la capacité remarquable d'adaptation de cette communauté, et leur détermination de survivre et de se réinventer au Canada. La discussion met en lumière la diversité ainsi que la complexité des sentiments d'appartenance, de domicile, de patries, chez mes répondants, et comment ces notions et ces liens sont en processus continuel d'évolution. Cette recherche a pour but de contribuer sur le discours de l'après-guerre et des réfugiés, et de faire évoluer le domaine au-delà des paramètres de la guerre et de l'exode du Vietnam, afin de pouvoir étudier les Vietnamiens dans toute leur complexité, dans le contexte d'un nouvel environnement.

Ah, the stories we tell and the stories told to us.

-Caroline $\mathrm{Vu}^{1}$

$\mathrm{M}$ emories of the boat journey still trigger strong emotions within the diasporic community decades after their departure from Vietnam. Forty years after that war, stories about the boat journey continue to be told and retold through memoirs, academic research, films, television, and radio programs. ${ }^{2}$ The narratives of six Vietnamese-Canadians highlighted in this article show not just the diversity of the "boat people's" experiences, but also its complexity and deeply personal aspects. The first section provides a brief historical overview of Vietnam's refugee crisis. The following sections explore different facets of my respondents' "boat journeys": their reasons for leaving Vietnam, their departures from Vietnam and experiences at refugee camps in Southeast Asia, and the challenges of adapting to their new lives in Canada. Finally, the discussion will examine their current perspectives of and ties with Vietnam.

\section{Respondents and Methodology}

In-depth life-story interviews were conducted in Ottawa between October 2014 and April 2015. Through the snowballing method, I was able to meet and become acquainted with my respondents. To capture the diversity of "boat 
experiences," I sought and selected individuals who had different motivations for leaving the country and espoused varying cultural outlooks and perspectives about Vietnam. My respondents originated from different regions in Vietnam; all live in Ottawa except for one, who is based in Toronto. They range in age from the mid-40s to 6os; all are universityeducated and white-collar professionals. Three have made several return trips to Vietnam over the past two decades, whilst the rest have not been back since they fled the country.

The interviews were conducted primarily in Vietnamese, since it is the language my respondents felt most comfortable with. The interviews ranged from an hour to three hours long each time, typically taking place in cafes and restaurants in the Chinatown area of Ottawa, and in the case of one respondent in a home. ${ }^{3}$ These venues were not only the most convenient and easily accessible for my respondents, but were also spaces they were familiar with and felt comfortable in. The interview questions were semistructured and open-ended. They sought to cover the major life domains associated with their refugee experience: experiences growing up in Vietnam, motivations for leaving the country and sense of "home" since their resettlement in Canada. 4

The narratives presented here are not intended to encapsulate the full spectrum of the sentiments and experiences of Vietnamese Canadians, or for that matter, the Vietnamese refugee diaspora. That is beyond the scope and resources available for this project. The purpose of this research is to describe these emergent themes and what they suggest about the notions of home and belonging for first-generation Vietnamese refugees. As a case study, researching Canada's Vietnamese refugee narratives is useful in understanding other diasporic groups in the country who have followed similar trajectories. Their myriad departure and resettlement experiences can teach lessons about cultural change, the construction of communities, and the evolving meanings of identity, home, and culture. These narratives also shed light on the various forms that national membership and belonging can take shape.

\section{Vietnam's “Boat People”: A Brief Historical Overview}

The second Indochina conflict (1954-1975) resulted in the largest mass exodus of Vietnamese overseas. In the years following the end of the conflict and national reunification, more than one million former soldiers, civil servants, and teachers were subjected to học tập cải tạo (re-education), equivalent to a form of imprisonment whereby detainees were subject to years of intense political indoctrination and gruelling labour in secluded camps. Another million were forcibly de-urbanised and relocated to the khu kinh tê mới
(New Economic Zones) located in inhabited mountainous areas. 5 As a result of the deprivations of the postwar period, it has been estimated that between 1.4 and 1.5 million Vietnamese fled the country between 1975 and $1990 .{ }^{6}$

Between the mid-1970s and the 1990s, Vietnamese left the country in three distinct waves. The first wave in 1975 included 140,000 southern Vietnamese, mostly political leaders, army officers, and skilled professionals escaping the communist takeover. In the second wave (1978-81), close to 400,000 refugees fled Vietnam. Due to the fact that many of these refugees typically fled the country onboard overcrowded and dangerously constructed boats, the popular misnomer "boat people" became the new term of reference for all Vietnamese refugees. Ethnic Chinese made up 70 per cent of the boat people. The third wave left Vietnam as part of the Orderly Departure Program (ODP).7 By the mid1990s, over 200,000 Vietnamese had entered the United States through the ODP. ${ }^{8}$ Each wave faced complex contexts of exits and resettlement that affected family dynamics and adaptation. 9 By the end of the 1990s, the vast majority of Vietnamese refugees were eventually resettled in the United States. Others found home in far-flung countries, including Australia, Canada, China, France, Great Britain, and Germany. ${ }^{10}$

\section{Life after the Fall of Saigon}

My respondents reflected how both their family and personal lives were affected by the change of political regime. Life for them had not changed drastically in the immediate period following communist victory over South Vietnam in 1975. By the late 1970s, however, they would witness drastic changes in their daily lives as the regime embarked on aggressive socialization campaigns throughout central and southern Vietnam.

Dung was born in Hanoi in 1952. Her family fled to Saigon after 1954 for political and religious reasons; ${ }^{11}$ they were Buddhists who detested and feared communist rule. Dung's family lived in Saigon's Phu Nhuan district. She recalled how, after reunification, the communist soldiers moved into her family home and stayed there for a year. Dung found their mannerisms and lifestyle strange and shocking at the time: "I remember how dishevelled and malnourished these young men looked when they first arrived at our doorstep. They were out of touch with modernity and urban living, having fought and lived in the jungles for so many years. They didn't know how to use a stove and almost burnt our house down a couple of times. They were also unfamiliar with modern sanitation; the flush toilet was a shocking discovery for them. They used the toilet bowl to wash their clothes. We were completely flabbergasted when they took our family dog to cook and eat!"12
(C) Author(s), 2016. This open-access work is licensed under a Creative Commons Attribution-NonCommercial 4.0 International license.
Cette oeuvre en libre accès fait l'object d'une licence Creative Commons Attribution-NonCommercial 4.0 International. 
Like Dung, Phuong's family had to share their home in Danang, central Vietnam, with the victorious soldiers, who eventually took possession of the house. Then, he recalled feeling sympathetic towards the soldiers, whom he described as a "raggedy and starved band of men who had sacrificed their youth, and were willing to risk their lives for the sake of unifying the country."13 During the first round of the regime's socialization campaign, the family business in the sale of imported bike parts was targeted, and the shop was confiscated. Unlike the rest of his family, who were resentful and wary of communist rule, Phuong said he actually felt glad when the communists took over the South. He had always yearned for a single, unified country that was free from war since his childhood. This was a viewpoint that raised the ire of the rest of his family, who were vehemently opposed to communist rule.

By contrast, the experiences of the Le family in Quy Nhon, central Vietnam, were much more dramatic and distressing. Sisters Mai and Chi recounted how their father was arrested shortly after the communist takeover. He had been a manager of the us embassy compound in Quy Nhon. After 18 months in jail, their mother managed to secure a conditional release of their father by bribing the officials in charge of his case; Mr. Le was to serve the rest of his sentence under house arrest. However, this reprieve was short-lived. In 1978, armed police stormed the family house. Chi recalled, "The police tore apart every room in the house, searching for evidence to incriminate my father. They went through each page of our school books, emptied the cupboards, spilled bags of rice onto the floor. They rearrested him, even though they didn't find anything, this time sentencing him to 18 years behind bars in the notorious Xuan Phuoc re-education camp."14

During those years, their mother supported her seven children with earnings from her shop in the market. Phuong Mai recalled how their mother was adamant that the children's every need be met and that they should always be well-clothed and fed. "My mother wanted life to carry on as it was before our father went to prison, before the communists took over. Whenever we visited Dad, she would make sure we were dressed to the nines. It was as if it was Tet [the Vietnamese lunar new year] all over again! We also learnt never to say the word thèm [crave] to her, because she would go out and buy large quantities of whatever we craved! More than to assure my father, I think she really wanted to convince herself that we were all doing fine."15

Likewise, Nhung and her family were determined to ride out the uncertain times during the early years after the war. She recalled how she had both the opportunity and means to leave in 1975 , but did not:
There were many reasons that made it difficult for me to leave... the main one was the belief that a third, middle ground forcethat was neither communist or southern republic-would emerge and eventually take over the country. But mặt trận dân tộc giải phóng miên nam Việt Nam [National Liberation Front of South Vietnam], which we had believed was the third force, turned out to be a Việt Cộng organization after all.

I also didn't want to leave my parents in Vietnam. Even though I wanted to study overseas and had the opportunity to leave then, I decided to stay on to be with my parents. When it came time for me to resume my studies, I moved to Saigon to attend university there. I was reluctant to leave Danang at first, but my mother was adamant that I move to Saigon for my studies, since it had better educational prospects. ${ }^{16}$

The narratives reveal that my respondents chose to remain in Vietnam for various reasons. Mostly, they were reluctant to leave their families and loved ones behind. Then, there was also the hope and belief that things would not get worse. They would be proven wrong in this regard.

\section{The Epiphany: The Impetus to Leave}

In the early period following national reunification, Nhung recalled the initial optimism she about the new leadership. Like many youth then, she had "positive hope" that communist ideology and leadership would bring about peace, unity, social order, and equality in the country after decades of war. But this optimism vanished after she moved to Tay Son, a mountainous region in central Vietnam, to work as a teacher.

I taught English as a second language at a local school. Malaria was widespread in this area and many students and staff got sick. I learned that the communist dictum "One for All and All for One" was a scam. The new system was one in which only a minority of the high-ranking officials benefitted [cán bộ có ưu tiên]. The majority of the population were impoverished. People had neither enough food nor access to medical care and education. I saw how morally corrupt and inept the new regime was. The black market was rife. People took advantage of helpless or desperate people to profit from the ration coupon system. The new system brought out the worst in people.

Worst of all, we had no right to complain . . I I could hardly feed myself with my salary and had to keep my mouth shut when I saw anything wrong with the regime. My mother worried that someday I would burst out and be arrested for my "reactionary" thoughts and actions. ${ }^{17}$

Nhung knew she could not stay in Vietnam. Neither could her brother. He had been drafted to serve in the army a year earlier and her mother had bribed a high-ranking
(C) Author(s), 2016. This open-access work is licensed under a Creative Commons Attribution-NonCommercial 4.0 International license.
Cette oeuvre en libre accès fait l'object d'une licence Creative Commons Attribution-NonCommercial 4.0 International. 
communist official to get him out. However, he was still not safe, as he could be drafted at any time to fight in Cambodia. That was when her parents started to make plans for Nhung and her brother to leave the country.

Like Nhung, Dung's realization that she had little or no future in postwar Vietnam was made increasingly apparent in the postwar years. Politically and socially, she was considered "undesirable" and "problematic" under both regimes, because of her English skills and religious background. Under the old regime, she had been thrown in prison twice (in 1970 and 1972) for taking part in anti-war protests. Her actions led the Southern regime to label her a communist. Dung was also not trusted by the new regime because of her English language skills and considerable social network with Westerners in Saigon; they were suspicious of her, thinking that she might be a spy for the CIA. Under communist rule, religious groups were hit hard. During 1978-9, Buddhist monks had to disrobe, become civilians, and avow atheism in order to survive. Dung recalled how daily life got worse for Vietnamese people from 1976 to 1979: "No one was able to find work, because there was no work available. There was little or no health care available for civilians; hospitals were usually reserved for party officials. And there were no more foreign books, which I loved to read. Like Doctor Zhivago, which was one of my favourite novels in my youth."18

Mai and Chi's family were also determined to ride out the difficult times of the postwar period, believing things could not get worse than they already were. The turning point for them was when their parents learnt that their children would not be able to pursue higher education in Vietnam, being offspring of those who had worked with the "enemy." Of immediate concern was the likely prospect that their eldest son and daughter would be drafted into military service or sent to work in remote state farms respectively. It became increasingly apparent to them that their family had no future in Vietnam, and that if they were to survive, they had to escape. Their eldest son and his uncle were the first to leave in 1978 . They were eventually sponsored to Canada in 1980. Chi and Mai, then 15 and 12 years of age respectively, were next in line. Chi emphasized how difficult it was for her mother: "People underestimate how difficult it was for parents to send their children off on the boat, to split up the family like that. No, they were not cold, calculating parents who took this decision lightly. It broke my mother's heart to have to do this. But that was the only way for us, for the family to survive. And she had to make very tough decisions. I was so mad with my mum in the period before I left, I thought she didn't want me around to help her anymore. But now that I am a mother myself, I can understand the pain she must have gone through."19
A close family friend later told her how her mother cried after sending her two daughters off in the boat. People in the market recognized that it was such a sacrifice for her mother to send her eldest daughter, likening the decision to that of cutting or losing your right arm. Chi was her mum's right arm-helping with the business and the home.

\section{Leaving Vietnam: The Boat Journey}

For Nhung, her family's first attempt to escape in 1979 failed; they had been cheated by fake organizers and boat masters. They lost so much money after several failed attempts that her father, in despair, once considered committing suicide. Finally, her parents decided that with the gold they had left, they would send only Nhung and her brother. If the siblings were arrested, they would bribe them out of prison and make another attempt. In July 1980, Nhung left Danang with her brother, on a small boat with 41 people and a dog. She recalled that the boat master was young, inexperienced, and clueless about boats. ${ }^{20}$ After five days at sea, they encountered two typhoons. During the second typhoon, Nhung thought they would die. ${ }^{21}$

The Le sisters encountered horrific storms on their boat journey out of Vietnam as well. With their eldest brother and uncle in Canada, it was time for Chi, as the eldest daughter, to leave also. By then, however, security was much tighter and it became much harder to escape. Chi estimates that she had made twenty attempts to escape: four times she had gotten lost; the other times the assigned boat did not turn up. During the second-last attempt, the vessel she was travelling on was discovered by local authorities; Chi was thrown in jail for two months. In 1981, in her final attempt, Chi left on a boat purchased by her mother, together with her younger brother Minh, Mai, and y young cousin. She recalled,

The boat sailed to a fishing village off the coast of Quy Nhon, and then it ran out of fuel. The two young men manning the boat tried to steal fuel from fishing boats in the area. They were desperate and had no weapons whatsoever, so the two men covered a wooden stick with a cloth, and tried to pass it off as a rifle, instructing passengers to light a fire cracker each time they "fired." It was a pathetic and laughable ruse, because we could see the wooden stick protruding from under the cloth at times! However, the two men, who were native to this region, were immediately recognized by those they were trying to rob. The villagers asked them why they were doing this, when they would have gladly helped the men had they been asked in the first place. The villagers not only gave us fuel, but also food, and told us the best places to hide in the vicinity to avoid detection. ${ }^{22}$

The crew sailed on to Macau. Along the way, the craft was hit by three storms. In one particularly horrendous
(C) Author(s), 2016. This open-access work is licensed under a Creative Commons Attribution-NonCommercial 4.0 International license.
Cette oeuvre en libre accès fait l'object d'une licence Creative Commons Attribution-NonCommercial 4.0 International. 
one, the waves sent the boat flying up, suspended in mid-air, and then crashing down each time. Chi and Mai recalled being terrified. The boat eventually drifted onto the coast of Macau. They recalled the locals as kind and friendly folk who pointed them in the direction of Hong Kong. When they reached Hong Kong, they had to dock for one week for quarantine.

By comparison, the boat journeys for the others were relatively uneventful. The ease in leaving the country during the late 1970s was aided by the regime's ostensible policy to "facilitate" the departure of its Chinese residents. There was brazen official endorsement, encouragement, and collusion to expedite the outflow of Chinese-Vietnamese. Profiteering and racketeering were rampant among officials. ${ }^{23}$ Many ethnic Vietnamese seeking to escape bought Chinese papers to facilitate their departure. Khue's mother bought Chinese identification papers and tickets for Khue and his brothers on a big ship, which was intended for ethnic Chinese-Vietnamese leaving the country. The normal fare was between six and seven taels of gold, but because theirs was an emergency sale, the cost doubled. Their mother took them to the ship in the coastal city of Vung Tau in the middle of the night, instructing them not to speak Vietnamese under any circumstance, and only to say their fake "Chinese name" when asked about their identities.

\footnotetext{
The ship was huge. It was empty at first. I even had a room to myself. I felt excited. It was like I was going on a vacation! After two days, the ship filled up with 1,500 people. As the ship went up along the coast, I could still see Vietnam. Even though I was no longer there, Vietnam was never far from me. At one point of the journey, I could even hear bombing and shouting along the border with China. It was strangely comforting and yet sad, to be so close and yet so far from my homeland, and to hear the conflict still going on while I was escaping. I could hear shooting and shouting along the coast. ${ }^{24}$
}

The ship ended up on a small island off Hainan, China's southernmost province. There the Chinese coast guard let them in. The villagers sold food to the refugees and fixed their damaged ship for a fee. They would spend about a month on the island before departing for Hong Kong. However, they learnt that another bigger ship attempting to enter Hong Kong had been stopped and turned around by the coast guard. The vessel then proceeded to an island close to Macau, whose authorities eventually sent them to Hong Kong. There, they would spend about three months at the Whitehead detention centre.

Like Khue, Phuong's family bought Chinese papers for him and his brother, paying about 10 taels of gold per passenger. Phuong said he was sad to leave Vietnam and did not want to leave the country, because he had a high school sweetheart in Saigon. However, his parents were adamant that the whole family had to leave and quickly made arrangements to do so. In December 1979, the brothers left from Soc Trang, southern Vietnam. Phuong recalled being escorted by the local police boat out of the country that night; they followed their vessel all the way out and even bid them farewell before turning back. Phuong's parents and the rest of the family were the last to leave. They all ended up in different camps and would lose contact with each other for the next few years. Most of his family were resettled in Belgium. Phuong recalls, "The boat was really a fishing boat, packed with about 228 people. It sailed for three days. It seemed like we were heading to the middle of nowhere. Then, there was a big storm. I really thought that we were all going to drown then. When we reached the Malaysian coast, our boat masters deliberately sank the boat so that the coast guard would have no choice but to rescue them and let them on the island. They must have heard about the experiences of others who had unsuccessfully tried to land in Malaysia."25

In early 1981, Dung departed from Ca Mau, a city in southern Vietnam, in the wee hours of the morning. To avoid raising suspicion, the passengers were instructed not to bring anything for the journey. If they got caught, they were to say that they were not escaping but "catching fish." She recounted how some relatives had been caught earlier, and the police found lots of personal effects on them that indicated they were leaving the country. They were thrown in prison for months.

Along the way, the boat they were travelling on was attacked by Thai pirates. Dung recalled the pirates as young and somewhat inexperienced. There was not much they could steal from the passengers, since they did not have much to begin with. The pirates ended up taking diesel and some other small items from the boat. They seemed to relent when they saw a picture of Buddha on the boat, and returned the items to the passengers. Dung guessed that their assailants might have been Buddhists themselves, and felt guilty about robbing them. The one aspect of the boat journey that remained vivid and entrenched in her memory after all these years was the "strong and unbearable" smell of diesel (mùi xăng) in her hair. When the pirates ransacked the boat, they knocked over the barrel of diesel, which leaked onto the passengers hiding below the deck. For the rest of the journey, Dung had diesel all over her hair. She longed to wash it but could not. During those days, she thought that she was truly going crazy and was afraid that she was not going to make it to the next destination alive.

The boat eventually reached the coast of Pulau Bidong, off Terengganu in Malaysia. It circled the island for about four
(C) Author(s), 2016. This open-access work is licensed under a Creative Commons Attribution-NonCommercial 4.0 International license.
Cette oeuvre en libre accès fait l'object d'une licence Creative Commons Attribution-NonCommercial 4.0 International. 
nights and five days. The crew and passengers had lost sense of time and geography, and some actually believed that they were still close to Nha Trang, in central Vietnam. Fortunately for them, by the 1980 s, UNHCR had made an agreement with the Malaysian authorities, allowing refugees to enter the camps. The locals along the coast shouted and waved at them, pointing them in the direction of Terengganu. Dung recalled the Malay folk along the shore throwing cigarettes towards their craft, asking them to smoke and gesturing to them that they were safe now. ${ }^{26}$

\section{Life in the Camp}

For refugees, the conditions and quality of life in the camps varied according to their location; different camps had different policies, resources, and arrangements with the UNHCR and local authorities. Hong Kong had the largest and most organized camp structures. Camp conditions in Pulau Bidong, in Malaysia, on the other hand, were rudimentary.

Upon reaching the shores of Hong Kong, Nhung and the other passengers were escorted by the Hong Kong Royal Marine Police to a big dock, where they were quarantined for a week. After they were allowed to land, they were placed in a prison for another week while the Hong Kong immigration officers and UNHCR processed their paperwork. They were then released to an open camp where they could work outside of the camp while awaiting resettlement. There, Nhung worked as an interpreter for the Red Cross clinic. "There, I saw many things that I had never before seen: victims of spousal and child abuse, robbery, orphans whose mother was murdered the night before, abortion, the birth of twins, death, so many types of diseases." 27 Nhung stayed in Hong Kong for six months before being sponsored for resettlement in Canada.

Chi and Mai's stay in Hong Kong was also brief. After the initial quarantine, they were moved to Jubilee camp (the first in a three-tiered camp structure). After a month, they were able to move to Kai Tak camp, where refugees had significantly more freedom of movement. There, refugees were able to leave the camp on day passes for work. Coming from a sheltered upbringing in Vietnam, camp life shocked Chi and Mai: robberies, rapes, and murders were not uncommon. For Mai, however, the hardest thing for her was seeing people live out most of their lives at the camp: getting married and raising a family there, playing what seemed like an eternal waiting game to be accepted for resettlement.

At Kai Tak camp, the sisters said they were fortunate to have met a middle-aged Vietnamese couple, who took care of and watched out from them, treating the teenagers as their own children. Chi and Mai say they are grateful for the kindness shown to them and will never forget these two people, although they did not keep in touch after leaving the camp.
After a few months, they were transferred to Argyle, the final-stage camp before being allowed to leave the country. They stayed in Hong Kong for four months before leaving for Toronto in January 1982. The Le sisters were sponsored by their uncle and elder brother who were already there. ${ }^{28}$

Camp conditions in Malaysia were generally rudimentary and unsanitary. At Shillington camp on Pulau Bidong, Phuong recalled that living conditions were terrible: "There was no sanitation at the camp. Food was sponsored by the Red Cross. There were no trees at the camp, which faced the ocean. It was like a real concentration camp, surrounded by barbed wire." 29 He said he was thankful that he was able to put some of the knowledge and skills he had picked up as a Boy Scout in his youth to use during his stay at the camp, such as cooking, and pitching tents. Dung's recollection of camp life were similar; she recalled how there were rats and cockroaches everywhere, and food-borne and infectious diseases were rife. During her time at Bidong, she suffered from dysentery for weeks. She also had head lice and had to put diesel on her hair to kill the lice. To pass time at the camp, Dung worked as a translator, helping with the medical and dental checkups for the refugees. ${ }^{30}$

\section{Coming to Canada}

Between 1979 and 1981, Canada accepted 60,00o Vietnamese refugees. Those who arrived during this period described a relatively easy and quick resettlement. By 1985, 110,00o Vietnamese refugees had settled in Canada. ${ }^{31}$ Nhung received approval to come to Canada in December 1979. She arrived in early January $1980.3^{32}$ Although the United States was a viable option for Nhung's family, because her father was a former employee of the South Vietnam administration, and they were eligible to move there under the oDP program, Nhung chose Canada for pragmatic and personal reasons. It was easy for her to come to Canada and eventually sponsor her family. Furthermore, her experiences growing up near the us military base in Danang left her with a distaste for American culture and negative associations with the war:

Most of my fellow boat people went to the United States, but I preferred to come to Canada. I was still haunted by the war and did not want to be reminded of it. Also, the behaviour of the American soldiers did not leave me with a good impression of American culture; they were boisterous, noisy, and did not seem very intelligent! Canada struck me as a peaceful country. I was impressed by the simplicity and elegance of the Canadian flag: there was no star, no sun, no moon, and no stripes. There was just a leaf. How modest and how nice. 33

Arriving in Ottawa with her brother in early 1981, Nhung saw snow for the first time and experienced how cold it
(C) Author(s), 2016. This open-access work is licensed under a Creative Commons Attribution-NonCommercial 4.0 International license.
Cette oeuvre en libre accès fait l'object d'une licence Creative Commons Attribution-NonCommercial 4.0 International. 
could get in Canada. She described the first few years of life in Canada as tough. She could not sleep well for the first two years and had continual nightmares of her boat journey: the typhoons, being thrown around on the seas, and waking up afraid. In the early days of her resettlement, Nhung not only felt like a fish out of water, but was also ridden by a profound sense of guilt:

Back then, the Vietnamese community was very small. There were no Vietnamese restaurants in Ottawa and only one Vietnamese grocery store. I did not know many people. For the first few years after I arrived in Canada, I was homesick and plagued by guilt. The letters from Vietnam were deeply distressing. Our family had been labelled "traitors" and the Vietnamese government did not allow the "traitors" relatives to leave the country under the "traitors"' sponsorship. My mother frequently wrote about her fear of never seeing us again. Relatives and friends would write about how their families were starving or gravely ill, asking us to send money home to them. I lived in guilt and could not eat well. I thought that I had no right to enjoy good food in Canada if my people in Vietnam were starving. So I ate just to live. ${ }^{34}$

During the first year, she worked at the assembly lines of Digipix System, a digital satellite imaging company. Soon after, she enrolled at the University of Ottawa, studying sociology, while working part-time at the National Library. Upon graduating, Nhung went to law school for an additional four years. She became a lawyer in March 1990, opening a law practice the same year. In July 1991, she went on a fact-finding trip to Southeast Asia refugee camps, including Hong Kong for a month. Then, Nhung felt proud to be able to return as a lawyer helping others, not as a refugee.

Like Nhung, Khue had a fairly quick and easy process coming into Canada. He and his brothers arrived in Montreal in August 1979, moving to Toronto shortly after. Adjusting to life in Canada, however, proved to be an insurmountable challenge for Khue. After graduating from high school, Khue moved to Ottawa, where he studied engineering at Carleton University. He quit his studies at the age of 25, after struggling with classes and projects. Khue traced the start of his depression to this period. It was also then that he sponsored his parents to come to Canada. He felt a deep sense of shame at his lack of academic success and found it hard to face his family. Khue moved to Montreal shortly after his parents came to Canada. There, he washed dishes to get by and went on welfare for the next three years. Khue described himself as a "lost guy" during this period.

Eventually, Khue moved back to Ottawa and enrolled in an accounting course at Algonquin College. After he got his degree, he felt like a "normal" person and regained his pride. For the next two decades, Khue worked in a series of jobs-accounting, administration, and real estate-but could not find meaning and satisfaction. Then his health broke down. Eight years ago, Khue developed kidney failure. He now lives in Toronto, close to his family, and has been on dialysis for six years. He is at the top of the wait list for a kidney transplant.

Khue reflects that his illness was a turning point in his life and gave him a much-needed new perspective: that his past failures did not matter, they were not as important as his health and life itself. It also gave him the opportunity to discover his real passion, writing. He has been writing for more than two years now. It is through writing that he was able to get the self-respect, meaning, and fulfilment he had longed for. At present, Khue feels that he is ready for anything, and is no longer afraid of criticism, failure, or death. Khue hopes to publish a collection of short stories and a novel in the near future. ${ }^{35}$

Dung's arrival in Canada in early 1981 also marked new beginnings in her life, albeit in a rather literal way. Upon arrival at the airport, Dung and other refugees were instructed to throw away their old clothes. They were then sprayed with disinfectant, told to wash their hair and to shower, and were given new clothes. The refugees were resettled according to their boat arrival period or number. The majority of those on Dung's boat were resettled in Calgary, which was then a booming city in need of workers. For Dung, the first few years in Calgary were tough. She found the weather punishing and the social landscape isolating. She experienced first-hand what it was like to be a member of a minority in terms of ethnic background and social class:

I used to work 10- to 12-hour days when I lived in Calgary. After work, I would catch the night bus home. I never really felt scared or alone on those trips, because there were also many workers on the bus, who were mostly from immigrant backgrounds like myself. Once, there were a few white people on the bus who stared rudely at me. One of them then spat at me. I was shocked and didn't do anything. Then, a few passengers, who looked Inuit to me, told me not to worry and not to think too much about the incident, that this happened to them on a regular basis. It was then that I realized that those white passengers had mistaken me for an Inuit or aboriginal. That was my first encounter with racial discrimination..$^{36}$

After moving to Ottawa, Dung worked as a social worker for a few years, focusing on improving the mental health of refugees and other victims of trauma. She then worked for immigrant services at the City of Ottawa. Her job was to help create a new advocacy program for refugee women. During this period, she also studied part-time for a master's degree in social work. Dung then worked as a case
(C) Author(s), 2016. This open-access work is licensed under a Creative Commons Attribution-NonCommercial 4.0 International license.
Cette oeuvre en libre accès fait l'object d'une licence Creative Commons Attribution-NonCommercial 4.0 International. 
coordinator for social services at the City of Ottawa until her retirement a few years ago.

Chi and Mai arrived in Toronto in January 1982, joining their elder brother and uncle in Toronto. The following year, the Le siblings moved to Ottawa, so that their brother could study computer engineering at the University of Ottawa. The sisters recalled the small and crammed space they had to share for the next few years. In the one-bedroom apartment, the four siblings shared the same sleeping space and a cardboard box served as both a dining and study table. It was Mai who adapted the most easily and most quickly, because she was the youngest. Her elder brother and Chi became surrogate parents-often clashing with Mai. Power struggles dominated their relationship. They frequently wrote letters to their mother in Vietnam, taking care to highlight that they were doing well and studying hard, because they did not want her to worry. Likewise, their mother never mentioned anything that was not positive in her correspondence. Both sides were struggling in their own way but never let the other know. The Le siblings studied hard and took ESL, all of them graduating with computerrelated degrees.

The siblings managed to pool together their earnings to sponsor their remaining family in Vietnam, and their mother eventually joined them in 1992, along with three younger siblings and grandmother. They also saved enough money to buy a house for the family. Their father would join them in January 1995. He had aged much since they last saw him twenty years previously. Mai recalled how their family members walked on egg shells for the next few years. After their father went to re-education camp, their mother became the new head of the family and made all the decisions. Their father found it hard to adapt to and accept the changed family dynamics. ${ }^{37}$

\section{The Ties That Never End: Vietnam}

There are those who have gone back and those who have not. While some reject any form of engagement with Vietnam, many are optimistic that continued socio-economic growth will lead to positive political changes. Some returned to Vietnam to renew kinship and social ties. Nhung returned to Vietnam twice, in 1997 and 2006. During her first trip, she visited her former hometown in Danang and the mountain where she used to teach, describing the reunion with relatives, childhood friends, former colleagues, and students as heart-warming and moving. It was also during those trips that she was able to make peace with her past and to gain clarity about where her home and belonging were now: "I saw how much Vietnam had changed. I had changed much too. Danang was too crowded for my likingVietnam's population has doubled since I left. Going back to
Vietnam made me realize, more than ever, that my home is in Canada." 38

Nhung feels that although Vietnam has changed and is now more developed than it was in the 1970s, she still feels that the country could have done much better. She recalled how during the 1960 s, South Korean officials had come to Saigon on study missions to learn how to build a modern and developed city. South Korea grew by leaps and bounds in the 1990 s and early 20oos. The problem with Vietnam, in her opinion, was the lack of good leadership and management. However, many of the country's "best and the brightest" fled the country in the 1970s. Even now, many bright and promising Vietnamese are still leaving the countryand it is this very demographic the country needs to further modernize its economy.

Like Nhung, Phuong has also made peace with his past. He related how he used to take part in anti-communist protests when he first arrived in Canada and was actively involved with the Vietnamese community in Ottawa. Then in 1995 there were two milestones in his life. After the breakdown of his marriage, he went to live in Paris for two years and became a monk there. Through meditation, Phuong said he was able to attain a spiritual awakening and inner peace; he no longer blamed the communists for what happened in Vietnam and in his personal life. During his time in Paris, he came across documents that gave him new perspectives about the war, and he was able to have a more holistic view of Vietnamese political history:

By the early 1970s, the us had already decided to pull out of Vietnam, and made arrangements with the Soviet Union. Vietnam was, in a sense, caught in the middle, after the us left Vietnam to Russia. When I came to this understanding, my grudges against Vietnam melted away ... that was how the communists came to control the whole country. Communism as a political ideology was originally intended as a tool to get rid of colonialism. It was a violent tool to achieve a specific goal ... but it did the job.

I don't want the Vietnamese people to be divided anymore. The communists succeeded in unifying the country, unlike the other political forces or earlier nationalist groups, and I give them credit for that. Vietnam has done much better, progressed significantly from what it was during the 1960s and 1970s. Even though it is far from perfect, and many things could improve, it is still moving ahead. That is much better than chaos or total anarchy. It is easy to stay on the outside and criticize, but all this hatred is not effective in changing the country. The critics have been extremely vocal about the regime and the current state of affairs but have not offered any viable solution. ${ }^{39}$

Phuong's new views about Vietnam brought him inner peace and acceptance of his past, but have also estranged
(C) Author(s), 2016. This open-access work is licensed under a Creative Commons Attribution-NonCommercial 4.0 International license.
Cette oeuvre en libre accès fait l'object d'une licence Creative Commons Attribution-NonCommercial 4.0 International. 
him from the Vietnamese community in Ottawa. He was asked to leave the Vietnamese Canadian Federation when he started to express views that were not sufficiently anticommunist. His opinions, along with his pro-engagement stance, made him a "communist sympathizer" in the eyes of the Vietnamese community in Ottawa.

Phuong has returned to visit Vietnam twice, in 2001 and 2010. Each time he has been back, he feels that the country changed much; he could not recognize his old hometown in Danang, which had become a booming city: "Each time I have been back, I realize that Vietnamese people are still the same. We are essentially emotional and sentimental people, and that has not changed over time. I felt at home the first time I went back-I spoke the same language, and was able to connect with the people, instinctively. Even though I have changed much since I've lived in Canada, these changes were on the 'outer layer of consciousness' (e.g., education, work). The inner layer was still essentially Vietnamese. That is my cultural identity, and spiritual self." 40

During his returns, Phuong managed to produce a traditional music CD that is sold in major bookshops in Vietnam. He also has plans to help develop solar panels for houses in the countryside. Like Phuong, Dung has returned to Vietnam several times. A few years ago, she helped set up a school for autistic children in Ho Chi Minh City. In late 2014, she raised enough funds to enable teachers from Vietnam to attend an educators conference on autism in Montreal. ${ }^{41}$

Those who choose not to go back do so out of fear and uncertainty, and in the case of Khue, as a matter of principle. He has not been back since he left the country and said that he will do so only when the country is "free" (from communist rule) and in the hands of the people. Although he does not condemn those who choose to return, he resents those who go back to Vietnam to show off their wealth and act as if they are better than the locals. These people, he felt, were betraying the soul of the country. Khue felt that there was still much poverty and hardship in the country, and he could not bear to witness the conspicuous gap between the rich and poor. It would break his heart to see that. "Vietnam will always have a special place in my heart. There is an inherent passion to live and die where your parents were born, where you were born ... that's where my life journey began. When I pass on, I would like to have my ashes scattered in my former hometown." 42

Khue felt that Vietnamese have an inherent connection to their ancestral homeland, although such sentiments are complex and multi-faceted. Differences in political viewpoints can be divisive and sometimes contentious within overseas Vietnamese communities. Khue related a recent encounter at a community event in Toronto, where he was approached by volunteers to sign a petition in support of Bill
S-219, also known as the Journey to Freedom Act. ${ }^{43}$ Khue declined to give his support. His logic was that there were over a million overseas Vietnamese who returned yearly to Vietnam to tour and visit family, for business or philanthropy. These people were also returning in search their own "freedoms." He did not see the point of this bill, viewing it as moot and somewhat hypocritical. Khue's refusal to support the bill was greeted with shock and resentment by the community. Some accused him of being a communist sympathizer, a charge that Khue vehemently resented. To his detractors, he emphasized that he was "10o per cent boat person" who was against the communist regime and would not return until his country was "free."44 Khue's and Phuong's narratives highlight the diversity and complexity of relations between Vietnamese and their former homeland.

\section{Conclusion}

These narratives illuminate the different paths that brought Vietnamese refugees to Canada. Each story highlights the profound dilemmas, motivations, and experiences of Vietnamese refugees. Collectively, these stories demonstrate the remarkable resilience of this community, and their determination to survive and remake themselves in their adopted country, Canada. The narratives also highlight the differing politics-of community engagement, attitudes of return and non-return-among my respondents. These differences reflect the diversity and disparity in attitudes and behaviour within the wider Vietnamese community in Canada.

Through the lenses provided by the experiences of the six respondents, the discussion has shown not only how this segment of the diaspora has dynamic and complex relations with the ancestral homeland, but also how such relations are continually evolving. The narratives demonstrate how my respondents continue to connect with "cultural" Vietnam, despite their distaste for and disengagement from "political" Vietnam. They also reveal the diverse and multi-faceted ways in which this segment of Vietnamese Canadians conceptualize home and belonging.

There is a growing acknowledgment about the fluid and dynamic relations diasporic peoples have with home and homeland. 45 Home is the space where they currently reside, the place where their immediate family lives, the country of parental origins, and/or where other family members live. Being-at-home therefore involves the coexistence of these three registers of home, although each has very different-and fluctuating-meanings. ${ }^{46}$ It is therefore possible for trans-migrants and displaced peoples to have more than one home and to feel at home in more than one place or space. Seen in this manner, my respondents' current ties to and engagement with Vietnam can be construed as a microcosm of contemporary trans-migrants' multiple allegiances,
(C) Author(s), 2016. This open-access work is licensed under a Creative Commons Attribution-NonCommercial 4.0 International license.
Cette oeuvre en libre accès fait l'object d'une licence Creative Commons Attribution-NonCommercial 4.0 International. 
senses of belonging, homes, homelands, identities, and belongings-which are marked by diversity and complexity and are continually evolving and never complete. In so doing, the research aims to provoke further work in the burgeoning and vital field of oral history, which will provide deeper and more concrete understanding of questions concerning ethnic affiliation, notions of belonging, and diasporic ties with the homeland.

Forty years after that war, Vietnamese in Canada are refugees no more, but an intrinsic part of Canadian society and the country's immigration history. These narratives reveal that for these former refugees, home is where they are now and where they see their futures. At the same time, Vietnam continues to hold a special place their hearts and minds. In this deeply personal and sentimental space lies a collection of things past, present, and still to come.

\section{Notes}

1 Caroline Vu, Palawan Story (Aylmer, QC: Deux Voiliers Publishing, 2014), 155.

2 See, for instance, Andrew Pham, Catfish and Mandala: A Two-Wheeled Voyage through the Landscape and Memory of Vietnam (New York: Farrar, Straus and Giroux, 1999); Thuy Diem Thi Le, The Gangster We Are All Looking For (New York: Alfred A. Knopf, 2003); Andrew Lam, Perfume Dreams: Reflections of the Vietnamese Diaspora (Berkeley, CA: Heyday Books, 2005); Journey from the Fall, dir. Tran Ham (Santa Monica: ImaginAsian Home Entertainment, 2006); Nam Le, The Boat (New York: Alfred A. Knopf, 2008); Kim Thuy, Ru (Montreal: Vintage Canada, 2009).

3 Interviews with the sixth respondent, who is based in Toronto, were conducted via phone.

4 It is imperative to remember what life history and narrative analysis remind us of about how people make sense of their life stories. When a person tells his or her life story, the information has been edited and events selected to create a story that is compatible with the present. Therefore, my respondents were not simply recalling facts, but also interpreting the past in the light of the present. See John Clausen, "Life Reviews and Life Stories," in Methods of Life Course Research: Qualitative and Quantitative Approaches, ed. Janet Z. Giele and Glen H. Elder Jr., 189-212 (Thousand Oaks, CA: Sage, 1998); Ruthellen Josselson and Aima Lieblich Aima, eds., Interpreting Experience: The Narrative Study of Lives (Thousand Oaks, CA: Sage, 1995).

5 During this period, the regime nationalized businesses and industries, collectivized agriculture, imposed currency reform, and confiscated private property wholesale. Chinese businesses and schools were closed in 1976, and Chinese-Vietnamese had to register their citizenship. Family members of former military personnel and administrative staff of the former South Vietnamese government were discriminated against in education and employment, as were the Chinese and Amerasians. See W. Courtland Robinson, Terms of Refuge: The Indochinese Exodus and the International Response (London: Zed Books, 1998); Robert S. McKelvey, Dust of Life: America's Children Abandoned in Vietnam (Seattle: University of Washington Press, 1998).

6 See Judith Banister, "The Population of Vietnam," International Population Reports, series P-95, no. 77 (Washington, DC: Us Bureau of the Census, 1985); Judith Banister, "Vietnam: Population Dynamics and Prospects," Indochina Research Monograph, no. 6 (Berkeley: Institute of East Asian Studies, University of California-Berkeley, 1993).

7 Initiated in 1979, the oDp that was intended to facilitate the departure of those who were associated with the former South Vietnamese government and military, and who had been subjected to years of imprisonment and systematic discrimination.

8 The 1988 Amerasian Homecoming Act and the 1989 Humanitarian Operation Program further led to the exit and resettlement of children fathered by American military personnel and the remaining former South Vietnamese prisoners respectively. See Paul Rutledge, The Vietnamese Experience in America (Bloomington: Indiana University Press, 1992); James Freeman, Changing Identities: Vietnamese Americans, 1975-1995 (Boston: Allyn and Bacon, 1995); Sucheng Chan, The Vietnamese American 1.5 Generation: Stories of War, Revolution, Flight and New Beginnings (Philadelphia: Temple University Press,2006).

9 Yen Le Espiritu and Tran Thơm, "Việt Nam, Nước Tôi: Vietnamese Americans and Transnationalism," in The Changing Face of Home: The Transnational Lives of the Second Generation, ed. Peggy Levitt and Mary C. Waters, 395 (New York: Russell Sage Foundation, 2002).

10 Robinson, Terms of Refuge, 127.

11 Following the French defeat at Dien Bien Phu, the country was partitioned into North and South Vietnam, in accordance with the Geneva Accords of 1954. The North would be governed by the communist forces, and the US backed non-communists in the South.

12 Dung, personal interview, Ottawa, 28 October 2014.

13 Phuong, personal interview, Ottawa, 25 October 2014.

14 Chi, personal Interview. Ottawa, 13 January 2015.

15 Mai, personal interview, Ottawa, 3 March 2015.

16 Nhung, personal interview, Ottawa, 17 October 2014.

17 Nhung, personal interview, Ottawa, 25 November 2014.

18 Dung, personal interview.

19 Chi, personal interview.

20 The young boatman would take wood from the boat structure, and chop it up to cook food on the island. He also did not know which direction to steer the boat, so her brother and two of his friends took over the helm, relying on the compass they had brought with them.

21 Nhung, personal interview, Ottawa, 25 November 2014. 22 Chi, personal interview.
(C) Author(s), 2016. This open-access work is licensed under a Creative Commons Attribution-NonCommercial 4.0 International license.
Cette oeuvre en libre accès fait l'object d'une licence Creative Commons Attribution-NonCommercial 4.0 International. 
23 Robinson, Terms of Refuge, 31.

24 Khue, phone interview, 2 April 2015. Between 1979 and 1980, Vietnam and China were embroiled in an intense military conflict along the Sino-Vietnamese border.

25 Phuong, personal interview.

26 Dung, personal interview.

27 Nhung, personal interview, Ottawa, 10 January 2015.

28 Mai and Chi, personal interview, 2 February 2015.

29 Phuong, personal interview.

30 Dung, personal interview, Ottawa, 5 November 2014.

31 "'Boat-People': A Refugee Crisis-Vietnamese-Canadian History," Radio Canada International, http:// www.rcinet.ca/patrimoine-asiatique-en/le-mois-dupatrimoine-asiatique-au-canada/les-refugies-de-la-merla-communaute-vietnamienne/.

32 In 1979, Marion Dewar, mayor of Ottawa, created Project 4,00o to resettle 4,00o refugees from Vietnam, Cambodia, and Laos in Ottawa through private sponsorship. Nhung was a beneficiary of this project.

33 Nhung, personal interview, 10 January 2015.

34 Ibid.

35 Khue, phone interview.

36 Dung, personal interview, Ottawa, 5 November 2014.

37 Mai, personal interview, Ottawa, 3 March 2015.
38 Nhung, ersonal interview, 10 January 2015.

39 Phuong, personal interview.

40 Ibid.

41 Dung, personal interview, 5 November 2014.

42 Khue, phone interview.

43 The bills seeks recognition of 30 April as a national day to commemorate the exodus of Vietnamese refugees and their acceptance in Canada after the fall of Saigon to North Vietnamese communist forces.

44 Khue, phone interview.

45 See Dorinne Kondo, "The Narrative Production of 'Home,' Community and Identity in Asian American Theatre," in Dislocation, Diaspora and Geographies of Identity, ed. Smadar Lavie and Ted Swedenburg, 97-118 (Durham, NC: Duke University Press, 1996); Alison Blunt and Robyn Dowling, Home: Key Ideas in Geography (London: Routledge, 2006).

46 Sara Ahmad, "Home and Away: Narratives of Migration and Estrangement," International Journal of Cultural Studies 2, no. 3 (1999): 329-47.

Priscilla Koh is an independent scholar based in Singapore. She may be reached at priskoh76@yahoo.com. 


\title{
A Case Study of the Vietnamese in Toronto: Contesting Representations of the Vietnamese in Canadian Social Work Literature
}

\author{
ANH NGO
}

\begin{abstract}
This article argues that the lived experiences and challenges of the Vietnamese community in Toronto are not reflected in the social work literature that continues to represent them as exceptional refugees. Over forty years after the fall of Saigon, a qualitative research study, "Discrimination in the Vietnamese Community, Toronto," reveals that the Vietnamese community continues to experience intergroup conflicts stemming from war-and displacement-mediated identities of region, class, and temporal periods of migration. A critical review of the social work literature, using the theoretical lens of critical multiculturalism, traces the construction of the Vietnamese Canadians as successful "boat people" as part of the larger narrative of multiculturalism. This discourse of exceptionalism allows the needs of those who fall outside the constructed identity to remain unseen and underserved. Participant responses from this small pilot study will inform future investigation into the impact of intergroup conflicts hidden under the veneer of successful integration and adaptation of refugee and migrant groups.
\end{abstract}

\section{Résumé}

Cet article propose que les expériences vécues et les défis affrontés par la communauté vietnamienne à Toronto ne sont pas reflétés dans la documentation sur le travail social qui continue de les représenter en tant que réfugiés exceptionnels. Plus de quarante ans après la chute de Saigon, une étude de recherche qualitative intitulée
"Discrimination in the Vietnamese Community, Toronto" (la discrimination dans la communauté vietnamienne à Toronto) permet de constater que la communauté vietnamienne continue d'éprouver des conflits intergroupes, façonnés par la guerre et le déplacement, qui découlent des identités régionales, de classe sociale et des différentes périodes de migration. Un examen critique de la documentation sur le travail social, à l'aide de l'optique théorique du multiculturalisme critique, retrace l'élaboration $d u$ discours sur les Canadiens d'origine vietnamienne en tant que "boat people» ou réfugiés de la mer qui ont réussi, comme faisant partie du discours général sur le multiculturalisme. Ce discours fondé sur l'exceptionnalisme empêche de rendre visible et de considérer les besoins de ceux qui se situent hors de cette identité préalablement construite. Les réponses des participants à cette étude pilote de taille limitée alimenteront des recherches postérieures sur l'impact des conflits intergroupes dissimulés sous l'apparence de l'intégration et de l'adaptation réussie des groupements de migrants et réfugiés.

\section{Introduction}

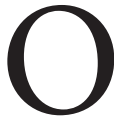

ver forty years after the official end of the war in Vietnam as marked by the 30 April 1975 fall of Saigon, the case of the Indochinese refugee movement in Canada is still widely regarded as an example of not only the resiliency and endurance of the human spirit, as witnessed in the refugees themselves, but also the compassionate and altruistic gestures of the Canadian population. In this article, I ask how this growing and diverse group of 
people continue to be essentialized under a singular identity of "refugeehood" and how this essentialization continues to affect them. ${ }^{1}$ I argue that the social work literature on Vietnamese Canadians, informed by the narrative of multiculturalism, continues to construct them as exceptionally legitimate and successful refugees, thus allowing lived experiences that fall outside of this identity to remain hidden. The participant data from a local study in intergroup discrimination refute this singular identity by highlighting regional, class, and temporal migration conflicts as they relate to lingering tensions from the Vietnam War. The implication of this narrow construction of a particular group is that it prevents educators and researchers from seeing the diverse struggles and needs of the Vietnamese Canadian community. First, I will review the demographics of the Vietnamese in Canada. Next, I will examine the findings of the literature review for examples of complicity in upholding the exceptional refugee narrative of the Vietnamese. I will then provide an in-depth review of the community-based study of the Vietnamese population in Toronto to contest the literature. A discussion on the experienced exclusion from community-belonging due to war- and displacement-mediated differences will highlight the diversity and continued conflicts within this population. I will conclude by asserting the implications of social work knowledge production in marginalizing the very communities that we aim to support.

\section{The Vietnamese in Canada}

In the 2011 census, the population of Vietnamese Canadians is estimated at over 220,000 on the basis of self-reporting of ethnic origin. ${ }^{2}$ This community's largest concentration of growth was during the refugee period. After the 1990s, many more arrived to Canada at a steady pace. A small cohort came as Convention refugees immediately after the end of the war in 1975/6, but most of the refugees arrived in 1979 and 1980. This group, commonly referred to as the Indochinese refugees or "boat people," came as part of the initial 60,000 people admitted under the special immigration partnerships between government and public, culminating in 125,000 by the end of this program in the early 1990s. 3 Since the end of the Indochinese refugee period of the 1980 os to the 1990 , from the 1990 s to 2014 , about 74,00o continued to arrive from Vietnam under the different immigration classes of family reunification, skilled workers, and economic migrants. ${ }^{4}$ In 2011, there were 70,725 persons of Vietnamese ethnic origin in the Greater Toronto area, according to the National Household Survey. 5 The City of Toronto alone counts 45,270 persons of Vietnamese ethnic origin, with 23,575 reporting Vietnamese as a mother tongue. ${ }^{6}$ In Toronto, Vietnamese ranked fifteenth in languages at home.7 Across Canada, Vietnamese ranked in the top 12 most languages spoken at home in five of the six largest census metropolitan areas of Montreal, Vancouver, Calgary, Edmonton, and Ottawa-Gatineau. ${ }^{8}$ Vietnamese refugees, and later migrants, arrived in Canada from different regions of Vietnam, class statuses, gender identities, and political allegiances. In the following section, I will review the literature that I argue upholds the discourse of Vietnamese as exceptional "boat people" refugees. This narrative reinforces the assumption that all Vietnamese Canadians are former refugees, despite the statistics that report close to 40 per cent of Vietnamese migrants to Canada arrived after the refugee period under different circumstances of migration.

\section{Constructing Vietnamese Canadians}

Scholars such as Sakamoto and Valverde critique the social work literature on its construction of communities as problem-centred groups in need of support. ${ }^{9}$ In Tsang's critique of North American social work literature, he traced the hegemonic construction of Chinese persons into a "dossier" to be known and to be practised on. ${ }^{10}$ While there is no definitive body of literature that is commonly known as "social work literature," this article draws upon academic work, including peer-reviewed journal articles, that social work practice and research relies heavily upon. The academic works may include the disciplines of education, health, migration studies, and refugee studies. The databases chosen for critical review are Social Services Abstracts, Sociological Abstracts, Pyschinfo, and Applied Social Sciences Index and Abstracts. An examination of keywords related to Vietnamese immigrants and/or refugees to Canada in these four databases was conducted among articles published from 1970 to 2015 . This search yielded 85 articles. A critical reading of the literature that informs social work research and practice reveals the dominant construction of the Vietnamese exceptionalism as legitimate and productive refugees several decades after the end of the Vietnam War.

\section{Vietnamese as Legitimate Refugees}

The social work literature on Vietnamese Canadians produced them as legitimate refugees. This construction, set within the broader context and discussion of "bogus" refugees or refugee smugglers, contributes to the discourse of the Vietnamese exceptionalism. This legitimacy is narrated in their rightful flight and suffering in their countries of origin. In describing the Vietnamese refugees' departure from their country of origin, the theme of a rightful flight, which constitutes legitimate "refugeeness," was used repeatedly. ${ }^{11}$ Beiser, a respected expert on the Vietnamese Canadians, contributes to this conversation in his work to draw attention and support for the refugees, and states that the
(C) Author(s), 2016. This open-access work is licensed under a Creative Commons Attribution-NonCommercial 4.0 International license.
Cette oeuvre en libre accès fait l'object d'une licence Creative Commons Attribution-NonCommercial 4.0 International. 
Vietnamese "refugees are survivors of oppression, plunged into poverty, purified by their sufferings, and boundlessly grateful for safe haven." ${ }^{12}$ Chan and Indra describe the unprecedented acceptance of these refugees: "Never before had the Canadian public become so actively involved, both through the private sponsorship of refugees and through massive volunteer involvement in settlement activities."13 The discussion of legitimate refugees contrasts with, and sets them apart from, other arrivals in the official context of "bogus" refugees, smugglers, and "economic" migrants. ${ }^{14}$

Few critical works contest the Vietnamese legitimacy, with the exception of Allen and Hiller who, in 1985, provided an early critique of the legitimate refugee discourse of the Vietnamese by tracing the individuals' process of becoming a refugee. ${ }^{15}$ The researchers interviewed 70 refugees who had arrived in Canada and described them as active subjects in the decision-making process, in contrast with the literature's common portrayal of a spontaneous flight. Strategic organization then occurs, such as the grouping of family and friends into escape ventures, solicitation of means of transport, and the payment and bribing of officials. These activities have since been cited as evidence of refugee smuggling operations in the 1999 case of Fujian Chinese refugees and the 2009 case of the Tamil refugees, yet Vietnamese refugees are rarely, if ever, remembered as such. ${ }^{16} \mathrm{I}$ argue this deliberate forgetting is part of the larger nation-building project.

Vietnamese exceptionalism was constructed in the 1980 s to serve Canada's nation-building project on the international stage as a leader in humanitarian rescue and refuge. During the time of destructive American action against another sovereign nation, Canada's role as an ally and chief arms supplier in the Vietnam War was quietly ignored, as the focus was kept on its humanitarian rescue and resettlement of war-created refugees. ${ }^{17}$ Critical theorists of Canadian multiculturalism vigorously interrogate the technologies of Canada's nation-building, one of which is the construction and maintenance of the "desirable" versus the "undesirable Other" to the nation. ${ }^{18}$ Racialized persons, immigrants, and newcomers have variously been constructed as outside the nation. Canadian multiculturalism then is deconstructed as a governing tool in which those outside the nation are managed to serve, paradoxically, the nation but to never fully belong within it. A well-known example is Canada's founding myth that has reinforced and continues to reinforce the narrative of Canada as a vast, empty nation founded by French and British colonial settlers. ${ }^{19}$ For instance, Haque's meticulous examination of government materials (transcripts of hearings, memos, reports, and policy documents) produced during the 1970s Commission on Bilingualism and Biculturalism reveals the deployment of this language policy to reinforce and, in effect, legislate the myth of two founding fathers under official bilingualism, with the rest of the nation as "multicultural Others." ${ }^{20}$ Indigenous claims to sovereignty and the land are erased, as well as the history of Black indentured persons, Chinese labourers, and racialized settlers. These groups have contributed tremendously to this nation in material, cultural, and social ways, yet their histories are discursively minimized as their descendants continue to struggle with racism and xenophobia as outsiders to the nation. The discourse on the Vietnamese as exceptional is an integral part of this over-arching governing tool of multiculturalism, which constructs and upholds them as legitimate refugees to be positioned innately against other racialized groups who are constructed as "bogus" refugees. From the literature, social work educators and researchers may know this group only as "legitimate" refugees, thus Vietnamese Canadians who have differing migration experiences may hesitate to seek social service help for fear of being misconstrued. Within social work literature, not only are Vietnamese Canadians portrayed as legitimate refugees, but they are productive as well.

\section{Vietnamese as Productive Refugees}

The literature problematically constructs Vietnamese Canadians as productive refugees who contribute to the capitalist nation. The literature on the Vietnamese describes them as a model minority in education, refugee adaptation, and participation in capitalism. ${ }^{21}$ Productive refugees are able to overcome their traumas and hardship to gain financial independence after a period of resettlement, no longer a burden on the state for charity. The frequent description of the refugees' dire situations under communism compared to their successes in capitalist Canada implies movement, positive difference, and progress. The Vietnamese refugees are described as "pathetic wretches struggling to escape from a nation which sought to enslave its own population" where the evil is communism that created the conditions forcing the flight of the nation's people. ${ }^{22}$ Beiser, Johnson, and Turner describe the Vietnamese refugees as "survivors of terror, upheaval, and forced incarceration." ${ }^{23}$ In infantilizing the refugees, Montgomery's methodology compares the relationship of theories of education to successful economic adaptation, comparing the data on refugees with those from previous studies on youth. This evokes images of Vietnamese refugees as underdeveloped, uneducated, and in stages of education and career readiness similar to those of the youths of Canada. ${ }^{24}$ Thirty years after the Vietnam War, Beiser recounts the model refugees' transition into model immigrants: "Within ten years, employment rates for the former Southeast Asian refugees were higher than the Canadian average, and there was no apparent difference 
in the rate of Southeast Asians versus native-born Canadian use of public services." 25 In appealing to the public on the successes of refugee rescue and resettlement, these scholars instead contribute to the discussion of this group as "exceptional," thus hiding the material struggles many of them continue to have as the result of structural and systemic barriers in Canada.

Model minority theorists demonstrate how the construction of Asian Canadians as the desirable immigrant subject dismisses and delegitimizes the political claims of Indigenous peoples and nonconforming racialized others. Under the model minority discourse, Asian Canadians' successes are attributed to their "culture" of hard work, self-reliance, and high value given to schooling for their children. ${ }^{26}$ Asian Canadians' successes are linked to "cultural" factors, thus leaving implicit the understanding that others groups' problems are also linked to cultural factors rather than structural racism, sexism, homophobia, and classism. In emphasizing this Pon states, “The Asian 'model minority' discourse also serves to reinforce the liberal belief that Canada and its institutions such as schools are accommodating, fair, and accessible to all those who work hard enough."27 Within the Vietnamese community, the model minority narrative does not allow for the space to voice the concerns that disrupt the images of them as a successful case of Canadian immigration and settlement. Accordingly, the Vietnamese communities are unable to discuss the lingering internal conflicts from the Vietnam War as a systemic issue in the context of multicultural Canada. Furthermore, the model minority discourse constructs the Vietnamese community who are transformed from the backwardness of communism into civilized citizens. Vietnamese "boat people" are therefore viewed as both legitimate and productive refugees who "pay back" the rescuing state and nation for their freedom. ${ }^{28}$ The social work literature on the Vietnamese communities is unable to recognize the needs of those who fall outside the celebrated and productive Vietnamese refugee group.

\section{Previous Studies on Intra-Community Diversity}

Few studies have queried the differences and conflicts within the Vietnamese Canadian community. Beiser, Noh, Hou, Kaspar, and Rummens's 2001 quantitative study based on local data queries the experience of discrimination by Vietnamese Canadians. They report 26 per cent of Southeast Asian refugees have had at least one experience of racial discrimination. ${ }^{29}$ Qualitatively, Phan interviewed school-aged youths in British Columbia and reported their stories of structural racism experienced from Caucasian teachers and peers in the school setting. ${ }^{30}$ Lay and Nguyen came closer to exploring intercommunity discrimination in an early quantitative study of Ontario university students who report intergroup discrimination as "hassles" as related to measures of depression..$^{31}$ These hassles, as it relates to Vietnamese culture, include language barriers within the community and exclusion based on not understanding idioms, jokes, slang, and an overall feeling of being left out. In a related study, Nolin analyzes the inter-group diversity due to country-of-origin conflicts as "ruptures" among Guatemalan migrants in Ontario. ${ }^{32}$ She argues that the experiences of having lived under political violence and repression, and the current state of political violence in Guatemala, continue to have effects on the lives of those in Canada in the form of community silences and mistrust. In related Vietnamese American studies, Espiritu explores intergroup diversity using the concept of "ethnicization" as a process of ethnic identity formation that includes differentiations in "the internal differences, social background, and class position of individuals within a minority group both before and after they arrive" in her study of the settlement successes of Chinese-Vietnamese Americans and Vietnamese Americans. ${ }^{33}$ Similarly, Vietnamese Canadians who have lived through the Vietnam War prior to migrating to Canada can be expected to have intergroup conflicts and division, an experience that has not been well represented within the literature. Little work has been done in Canada to analyze the heterogeneity of this community as it contributes to divisions on these grounds.

By supporting the conversation of Vietnamese refugees' exceptionalism, the academic literature contributes to a hegemonic narrative for this group of people. The following will be a detailed overview of a local study with the Toronto Vietnamese and a discussion of participants' experiences of intergroup differences and exclusion. These differences are mediated by the events of the Vietnam War that directly challenge the single narrative in the literature of this group as "legitimate" refugees and successful "boat people." Participants reported experiences of discrimination and exclusion within the community stemming from differences in regional origin, class status pre-migration, and temporal periods of migration. This will engage with the above literature reviewed that portrays the Vietnamese within one static refugee identity.

\section{Method}

In 2013, a local agency received a one-year grant to build the community's capacity by identifying and addressing exclusion and discrimination within the Vietnamese community to work towards collectivizing on shared challenges. This agency had identified intra-community conflict stemming from war- and migration-mediated identities as an impediment to the achievement of well-being for its Vietnamese clients and stakeholders. The case was made to the City of
(C) Author(s), 2016. This open-access work is licensed under a Creative Commons Attribution-NonCommercial 4.0 International license.
Cette oeuvre en libre accès fait l'object d'une licence Creative Commons Attribution-NonCommercial 4.0 International. 
Toronto's Community Funding Program, who had also heard of difficulties in coalition-building within the Vietnamese community. An exploration of exclusion and discrimination within the Vietnamese community was needed to assess the impact of these issues and start a dialogue with community members. The project consisted of a series of focus group meetings, interviews, and submitted responses on individuals' experiences of community, conflict, division, and discrimination. The agency's Community Advisory Committee of five members oversaw the project. In the interest of participant confidentiality in a community of this size, identifying data have been removed, which include the real names of participants, the name of the agency, and the name of the specific grant under which this project was funded.

The project consisted of focus groups and in-depth interviews using a semi-structured interview guide. In total, 28 participants attended the four focus groups, and 10 participants consented to an in-depth interview. Of the participants, over 60 per cent were women, the mean age was 49.4 , and the mean length of time in Canada was 14.5 years. Of the in-depth interview participants, 50 per cent were women, the mean age was 44.7 , and the mean length of time in Canada was 22.7 years. There was a diversity of participants from the different parts of Vietnam as they selfidentified as originating from one of the three main regions: North, Central or South. The focus groups were audiotaped and followed a loose discussion guide. The focus group interviews averaged two hours in length. Eight individual interviews were audiotaped, one was documented with interviewer memos, and one was documented with interviewer memos and participant-written follow-up in the form of an email. A standardized interview guide was used with five key focus points that allow for a participant-led discussion alongside the guide. The individual interviews averaged 1.5 hours in length. An incentive of twenty dollars was provided to all participants to acknowledge the value of their contribution. All focus groups and interviews were conducted in Vietnamese. The audiotaped data were transcribed first in Vietnamese and then translated into English. Participants shared their experiences of discrimination based on differences of regional origin in Vietnam, class, and period of migration. They also shared the impact of such discrimination from experiences of social exclusion to threats of violence.

\section{Discussion}

\section{Regional Identity Related to War}

Participants of the community study in Toronto reported experiences of exclusion based on their regional identity in Vietnam as relating to the events of the Vietnam War. Colonial domination and division of the country by several empires officially segregated the country into three regions: North (Bắc), Central (Huế or Trung), and South (Nam). During the major conflict that drove the Indochinese refugees to Canada, the country was divided into two, just south of the 17 th parallel, slightly north of the ancient imperial city of Hue in the Central region. The Geneva Accord of 1954 dictated this division, which continued until the end of the war in Vietnam in 1975.34 Participants reported that it was important to determine which region one originated from, as there is a common public perception that those from the Central and South Vietnam are legitimate refugees from the Vietnam War, while those from North Vietnam are naturally assumed to be communist and do not truly belong to the Vietnamese Canadian community.

Participants of the local study reported the common assumption within the diaspora that persons from North Vietnam are typically considered to be the minority in the Vietnamese community, as those from Central and South Vietnam were the initial groups that fled Vietnam following the end of the war. Regional dialects reveal region of origin. Participants reported the equating of a Northern dialect to a former if not current communist allegiance.

Xuân, a North Vietnamese woman, described a negative experience with a Vietnamese Canadian public employee who interrogated her political background in Vietnam when she called the public agency to seek services: "For me, I understand him. I am not mad at him. The truth is that many people assumed that the Northern people are people in the Communist party. Even just today, I was curious and didn't know what so-call the day Quốc Hận [National Grief] April zoth in City Hall is about. I was curious and in previous years' newspapers, I found out that people are getting together and they come to the Vietnamese embassy with their slogan against Communists." 35

Here, Xuân had described the annual commemoration and protest that some of the diaspora host each year to mark the fall of Saigon and to call on the Canadian government to boycott or to sanction Vietnam. Diasporic activities, which aim to influence the politics in the country of origin, in this instance, also harm some members of the diaspora itself.

Some participants described the surveillance and unwanted attention drawn to persons with a North Vietnamese dialect. Phủ, a South Vietnamese woman, stated, "Sometimes, when I hear they were speaking Northern voice, or laughing out loud or even swearing in the street, I don't care either. I just thought that they'd better not to do so." ${ }^{36}$ In this she suggests that a North Vietnamese person needs to conform, to conduct oneself "properly," to not draw attention to oneself within the Vietnamese community. She did not specify the consequences, but suggests that in order to fit in, North Vietnamese persons must "behave" at all
(C) Author(s), 2016. This open-access work is licensed under a Creative Commons Attribution-NonCommercial 4.0 International license.
Cette oeuvre en libre accès fait l'object d'une licence Creative Commons Attribution-NonCommercial 4.0 International. 
times in public. On the other side of the regional difference, those who use the North Vietnamese dialect reported being teased, with the result that the individual feels discriminated against. An, a woman in her late twenties, reported, "When I got a job in the community, some colleagues told me that I am a Northern girl (cô gái bắc ky). I knew that they were teasing me with that term, they were joking, but just half-joking. After all, I knew that they were discriminating against me. Anyway, I ignored it. I kept working on my own." 37 The consequence of this surveillance and unwanted attention to regional origin due to differences in dialect and used is self-exclusion from social participation.

Regional differences in the Vietnamese language ultimately distinguish how individuals belong to postwar Vietnam and to Canada. Taken together with the division of the country during the Vietnam War, with North Vietnam as the communist enemy and South Vietnam as the democratic ally to the United States, North Vietnamese persons today report feeling unwanted scrutiny and exclusion based simply on how they speak. Critically, both Northern Vietnamese participants discussed above, Xuân and An, are female and reported being directly interrogated and harassed for their dialects, while the male North Vietnamese respondents shared a general perception without offering direct experiences of harassment. The regional differences exacerbated by events of the Vietnam War contest the literature on Vietnamese Canadians as homogenous refugees fleeing communism. The experiences of local Vietnamese Canadians of alienation, exclusion, and discrimination when they do not fit into the legitimate refugee narrative remain hidden. The next facets of diversity reported among participants-class and migration period-are also experienced as divisive and discriminatory.

\section{Class and Migration Differences}

Class differences in Vietnam became complicated in the aftermath of the war in Vietnam first as the result of the refugee condition and later of massive changes in the global economy. Class positions were upended when the political and military elite of South Vietnam found themselves on the losing side of the war and arrived in Canada as refugees, often leaving all their possessions behind. Suddenly, the South Vietnamese elite found themselves in a socioeconomic status similar to that of as the lower classes of farmers and labourers. Yet class discrimination was still experienced within the refugee cohort. Hùng, a male senior participant who arrived as a "boat person," recollected, "When I just came to Canada, Vietnamese people who had come before 1975 by airplane looked at us with different eyes. They said, 'The slow buffalo has to drink muddy water.' They said those who came late did not get the benefits like those who came earlier nor ... were [they] as rich and well-educated as people who came first." ${ }^{38}$ The use of this common Vietnamese proverb to compare people to oxen is offensive and derogatory.

To further complicate the experience and effect of class in this community, the recent global context of a rising Vietnamese economy meant that those who were the elite of South Vietnam and who had fled in the 1980s are now faced with the reality that some of those who stayed on have prospered greatly. The Vietnam that the Indochinese refugees left behind is rapidly moving away from an impoverished war-torn Third World country towards becoming a regional and global economic player. ${ }^{39}$ Now middle-class Vietnamese are making their way to Canada via the economic migration routes. Participants reported they had commonly heard the stereotype that today's wealthy Vietnamese have profited under the current regime in Vietnam and therefore they must be communists. As Minh sums up the discussion, "Is it because they hate communism, they hate as well people who have lived in that country who they thought [were] already living with the communist regime and more or less accepted that regime? An indisputable fact is that most of the recent newcomers, especially the skilled workers or investors, and even overseas students [were] ... considered ... to have money [they were considered as part of the] higher class [of] the country."40 Minh arrived in Canada through the skilled-worker program in the $2000 \mathrm{~s}$ and reported that he faced suspicion and animosity from the Vietnamese Canadians he encountered at the time, as they did not believe he simply applied for and obtained immigration status into Canada without special help from officials in Vietnam.

The period of migration to Canada is directly related to class differences. The experience of exclusion based on this class difference is mediated by the legacy of the Vietnam War. Like regional differences, the way the Vietnamese language is used implies the historical and political period during which individuals migrated to Canada. Following the end of the war, during the period in Vietnam called the Reunification, language changed in subtle ways across the country. Phủ, a man from South Vietnam, reported how he stood out from the present Vietnamese in Toronto simply by his vocabulary: "When I just came here, I was considered by old settlers as 'New Vietnamese.' When I used new terms in my daily talk, they labelled me as Việt Cộng. Now I do the same to new Vietnamese newcomers." ${ }^{11}$ The Việt Cộng was the political and military force that fought against the South Vietnamese government in South Vietnam. Hai, another South Vietnamese who, like Phủ, arrived after the refugee period, shared his experience of exclusion when he tried to join in the community action on the issue of the contested Paracel and Spratly Islands. He stated he was told
(C) Author(s), 2016. This open-access work is licensed under a Creative Commons Attribution-NonCommercial 4.0 International license.
Cette oeuvre en libre accès fait l'object d'une licence Creative Commons Attribution-NonCommercial 4.0 International. 
at the local event, "Protests against China invasion of Hoàng $\mathrm{Sa}$ [Paracel], Truoơng Sa [Spratly] is our concern. You guys, newcomers, don't need to join us, because you guys sold lands and islands to China. Why do you need to be here to protest?"42 Hai's and Phü's experiences share the theme of perceived betrayal of the true Vietnam. Within the diaspora, the historical Việt Cộng are commonly insulted as the people who sold their country (người bán nước) during the war, yet today, while Việt Cộng no longer exist, at least not in the official sense, members of this community continue to insult one another as such.

Class differences within the Vietnamese Canadian community have not been represented in the social work literature. Participants reported that complexities of class diversity contributed to their experiences of discrimination. The difference in class status transferred from the country of origin is ignored in the literature's continued construction of Vietnamese Canadians as impoverished refugees who have now succeeded in the Canadian capitalist economy. The temporal effect of migration for this community is important, as those who arrived as Indochinese refugees in the 1980s have been assigned the mantel of the "legitimate" refugees, while those who arrived later are looked down upon as "economic" migrants. Within the Vietnamese Canadian community, these "economic" migrants are thought to have benefitted in socialist Vietnam following the end of the war and have now come to Canada to enjoy an established Vietnamese community built by the "legitimate" refugees. The lingering intra-community tensions from the Vietnam War exacerbate class discrimination as the refugee cohort- "boat people" who experienced horrific losses and hardship - are now faced with a growing mass of arrivals who stayed in Vietnam after the war and might have even prospered. Yet these later arrivals may have experienced other kinds of losses and hardships in postwar Vietnam, but their experiences are excluded. The singular construction of Vietnamese refugees as "wretches to riches" in the literature contributes to the division of the Vietnamese Canadian community. Those who can narrate a past of suffering under communism are taken to be the rightful Vietnamese Canadians, and those who cannot, remain unknown.

\section{Impact of Conflicts}

Participants reported that the results of intra-group differences are self-exclusion, discrimination, and the threat of violence. Self-exclusion occurred across identities. Participants from North Vietnam and recent migrants shared instances of exclusion in their daily work experiences or while seeking services. Often the other person simply refused contact. Participants reported measures of self-imposed exclusion to guard against potential negative interactions. Thu, an elderly South Vietnamese woman shared how she felt about her North Vietnamese peers: "When I saw a friend of mine posting a red flag [of present-day Vietnam] or Ho Chi Minh pictures on Facebook, I was initially very angry ... But then I thought over and I thought that I was luckily from the South ... They are living there, they had another education. So they are not like me. Forget it, those damn people. That's the respect of the differences." 43 Different experiences and perspectives in this case are not shared or discussed to seek common ground but rather are simply avoided.

An extreme impact of community division that participants reported is the threat of violence. Participants heard the threat or incidences of violence but also internalized it in "jokes" made in the focus groups. At a social gathering among those mostly from North Vietnam, Tam recounted that when the current official flag of Vietnam was displayed, "I heard that somebody had come and explained to them that our community was of the refugees and here is the refugee community. If you do things that irritate people's eyes (nguia măt), you might get in trouble. So you should not show red flags here. After the talk, then the red flags were removed." 44 Mai shared a similar story: "When I went to school in New Brunswick, we decided to choose which flag for a diversity day ... Most of the people studying in LINC [Language Instruction for Newcomers to Canada] are new, but they are afraid of using the red flag because it can cause conflict. However, we finally decide that we will use the flag, which is accepted by international bodies. But I remember one of my friends was saying, 'If you're in Quebec or the United States, you'd be dead for using this flag." 45

The threat of violence was experienced by participants but also internalized as fear. The most common and most visible transgressions are the display of the flag of presentday Vietnam, the display of pictures of the leaders of socialist Vietnam such as Ho Chi Minh, and the public singing or playing of "liberation" music created in Vietnam after 1975. There has been no documented incidence of such transgressions in Canada, but events in the United States demonstrate the strong and violent reaction that can ensue within the diaspora. In 1999 the owner of an electronics store in Westminister, California, displayed the current flag of Vietnam and a picture of Ho Chi Minh in his storefront. There were massive demonstrations, verging on riots, until the police arrested the storeowner on charges of media piracy. ${ }^{46}$ While this has yet to happen in Canada, the threat of violence alone warrants caution and avoidance of Vietnamese community engagement at organized events and activities.

The 28 participants in this small study reported either having been socially excluded, deliberately avoiding interaction with other Vietnamese Canadians, or hearing implied threats of violence against those who might transgress
(C) Author(s), 2016. This open-access work is licensed under a Creative Commons Attribution-NonCommercial 4.0 International license.
Cette oeuvre en libre accès fait l'object d'une licence Creative Commons Attribution-NonCommercial 4.0 International. 
community norms (for example, which flag to display, which national hero to honour, and even what type of music to play in public). This is a small but troubling snapshot of the range of experiences Vietnamese Canadians have had within their community. Those who struggle within this racialized migrant community, vulnerable to systemic barriers, might resist seeking informal supports within a community they do not trust. Yet all of this has been hidden within the social work literature that celebrates the narrative of Vietnamese as exceptional in their refugee plight and successful resettlement.

\section{Implications}

A critical reading of the social work literature on Vietnamese Canadians reveals a flat representation of this group as exceptional refugees who came to Canada through legitimate means and thrived under capitalism. Yet a local community-based study of Vietnamese Canadians in Toronto contests this narrow identity. Participants reported core differences within the Vietnamese community in Toronto as lingering effects of the Vietnam War based on markers of regional origin, class, and period of migration. These differences interact with and complicate one another to push back against the identity of "boat people." These differences and consequences are related to the events of the war in Vietnam that lead to participants' arrival to Canada either as refugees or migrants.

This discussion is intended to prompt further inquiry into the presumed homogeneity of the Vietnamese refugee group and their apparently successful settlement and adaptation. The social work literature, a powerful operation of knowledge production, is implicated in the marginalization of this group in upholding Vietnamese Canadians as exceptional refugees. Further studies are needed to examine the lived experiences of refugee and migrant groups who arrive to Canada with the baggage of civil war and local conflicts who are now expected to settle and adapt with one another under multiculturalism. The Vietnamese community in Canada is one of many groups who work to reconcile a history of conflict and division by civil war. This reconciliation is hindered, if not outright challenged, by dominant producers of knowledge such as the social work literature. This literature informs the very educators and researchers who hope to support this group, yet it continues to see Vietnamese Canadians as refugee "boat people" of the 1980s, thus missing experiences that are outside of this identity.

\section{Notes}

1 James C. Hathaway, "Refugee Solutions, or Solutions to Refugeehood?," Refuge: Canada's Journal on Refugees 24, no. 2 (2007): 3-10.
2 Statistics Canada, "National Household Survey: Immigration and Ethnocultural Diversity," 2013, issue 2011028, catalogue no. 99-010-X2011028," http://www5.statcan. gc.ca/olc-cel/olc.action?objId=99-010-X2011028\&objType $=46 \&$ lang $=$ en $\&$ limit $=0$.

3 Employment and Immigration Canada, "Indochinese Refugees: The Canadian Response, 1979 and 1980," Canadian Immigration Historical Society, http://cihs-shic.ca/ wp-content/uploads/2015/o3/Indochinese-Refugees-CdnResponse-report-ENG.pdf.

4 Employment and Immigration Canada, "Immigration Statistics 1966-1996," Library and Archives Canada, http:// epe.lac-bac.gc.ca/100/202/301/immigration_statistics-ef/ index.html; Statistics Canada, "Table 051-0oo6: Immigrants to Canada, by Country of Last Permanent Residence, Quarterly (Persons)," CANsim (database), http:// www5.statcan.gc.ca/cansim/a26?lang=eng\&retrLang=en g\&id=0510006\&pattern=vietnam\&csid=; Citizen Immigration Canada, "Facts and Figures 2014-Immigration Overview: Permanent Residents," http://www.cic.gc.ca/ english/resources/statistics/facts2014/permanent/10.asp.

5 Statistics Canada, "NHs Profile, Toronto, CMA, Ontario, 2011," http://www12.statcan.gc.ca/nhs-enm/2011/dp-pd/ prof/details/page.cfm?Lang=E\&Geo1=CMA\&Code1 $=535 \&$ Data $=$ Count $\&$ SearchText $=$ Toronto $\&$ SearchType $=$ Begins $\&$ Search $P R=01 \& A 1=A 11 \& B 1=A l l \&$ Custom $=\& \mathrm{TABID}=1$.

6 City of Toronto, "Backgrounder 2011 Census: Language," City of Toronto, 25 October 2012.

7 Ibid.

8 Statistics Canada, "2011 Census of Population: Linguistic Characteristics of Canadians," catalogue no. 98-314X20110001," Minister of Industry, October 2012.

9 Izumi Sakamoto, "Changing Images and Similar Dynamics: Historical Patterning of Foreignness in the Social Work Profession," in The Concept of Foreign: An Interdisciplinary Dialogue, ed. Rebecca Saunders, 237-79 (Oxford: Lexington Books, 2003); Mariana Valverde, The Age of Light, Soap, and Water: Moral Reform in English Canada, 1885-1925 (Toronto: University of Toronto Press, 2008).

10 A. Ka Tat Tsang, "Representation of Ethnic Identity in North American Social Work Literature: A Dossier of the Chinese People," Social Work 46, no. 3 (2001): 229-43.

11 LoanT.Phan,EdilTorresRivera, and JaniceRoberts-Wilbur, “Understanding Vietnamese Refugee Women's Identity Development from a Sociopolitical and Historical Perspective," Journal of Counseling and Development 83, no. 3 (2005): 305.

12 Morton Beiser, Strangers at the Gate: The "Boat People"'s First Ten Years in Canada (Toronto: University of Toronto Press, 1999), 170.

13 Kwok B. Chan and Doreen Marie Indra, Uprooting, Loss and Adaptation: The Resettlement of Indochinese Refugees in Canada (Ottawa: Canadian Public Health Association, 1987), 1.
(C) Author(s), 2016. This open-access work is licensed under a Creative Commons Attribution-NonCommercial 4.0 International license.
Cette oeuvre en libre accès fait l'object d'une licence Creative Commons Attribution-NonCommercial 4.0 International. 
14 Sean P. Hier and Joshua L. Greenberg, "Constructing a Discursive Crisis: Risk, Problematization and Illegal Chinese in Canada," Ethnic and Racial Studies 25, no. 3 (2002): 490-513; Maggie Ibrahim, "The Securitization of Migration: A Racial Discourse," International Migration 43, no. 5 (2005): 163-87.

15 Rebecca Allen and Harry H. Hiller, "The Social Organization of Migration: An Analysis of the Uprooting and Flight of Vietnamese Refugees," International Migration 23, no. 4 (1985): 439-52.

16 See Ashley Bradimore and Harald Bauder, "Mystery Ships and Risky Boat People: Tamil Refugee Migration in the Newsprint Media," Canadian Journal of Communication 36 , no. 4 (2011): 637-61, for an overview of the media's representation of the 1999 Fujian and the 2009 Tamil refugees as bogus refugees; and Alison Mountz, "Embodying the Nation-State: Canada's Response to Human Smuggling," Political Geography 23, no. 3 (2004): 323-45, for a critical analysis of Canada's immigration policy's responses in detaining these refugees.

17 Vinh Nguyen, "Refugee Gratitude: Narrating Success and Intersubjectivity in Kim Thúy's Ru," Canadian Literature 219 (2013): 17.

18 Himani Bannerji, The Dark Side of the Nation: Essays on Multiculturalism, Nationalism and Gender (Toronto: Canadian Scholars', 200o); Eva Mackey, The House of Difference: Cultural Politics and National Identity in Canada (Toronto: University of Toronto Press, 2002); Sunera Thobani, Exalted Subjects: Studies in the Making of Race and Nation in Canada (Toronto: University of Toronto Press, 2007).

19 Renisa Mawani, "Genealogies of the Land: Aboriginality, Law, and Territory in Vancouver's Stanley Park," Social \& Legal Studies 14, no. 3 (2005): 315-39; Daiva Stasiulis and Radha Jhappan, "The Fractious Politics of a Settler Society: Canada," in Unsettling Settler Societies: Articulations of Gender, Race, Ethnicity and Class, ed. Daiva Stasiulus and Nira Yuval-Davis, 95-131 (London: Sage Publications, 1995); Jean Burnet, "Myths and Multiculturalism," Canadian Journal of Education / Revue canadienne de l'éducation 4, no. 4 (1979): 43-58.

20 Eve Haque, Multiculturalism within a Bilingual Framework: Language, Race, and Belonging in Canada. (Toronto: University of Toronto Press, 2012).

21 Tan Phan, "Life in School: Narratives of Resiliency among Vietnamese-Canadian Youths," Adolescence 38, no. 151 (2003): 555; Louis-Jacques Dorais, "Refugee Adaptation and Community Structure: The Indochinese in Quebec City, Canada," International Migration Review 25, no. 3 (1991): 551-73; Phyllis J. Johnson, "Credit Card Practices of Vietnamese and Laotian Newcomers to Canada: A 10-Year Longitudinal Perspective," Journal of Family and Economic Issues 28, no. 2 (2007): 227-46.
22 Randal Montgomery, "Predicting Vietnamese Refugee Adjustment to Western Canada," International Migration 29, no. 1 (1991): 89-117.

23 Morton Beiser, Phyllis J. Johnson, and R. Jay Turner, "Unemployment, Underemployment and Depressive Affect among Southeast Asian Refugees," Psychological Medicine 23, no. 3 (1993): 731-43.

24 Montgomery, "Predicting Vietnamese Refugee Adjustment," 94.

25 Morton Beiser, "Refugees in Canada," Canadian Issues 1 (2004): 54-6.

26 Hijin Park, "Being Canada's National Citizen: Difference and the Economics of Multicultural Nationalism," Social Identities 17, no. 5 (2011): 643-63; Jane Ku, "Postcolonial Incorporation of the Different Other," Crossings: Journal of Migration \& Culture 3, no. 1 (2012): 33-51.

27 Gordon Pon, "Importing the Asian Model Minority Discourse into Canada: Implications for Social Work and Education," Canadian Social Work Review / Revue canadienne de service social 17, no. 2 (2000): 286.

28 Mimi Thi Nguyen, The Gift of Freedom: War, Debt, and Other Refugee Passages (Durham, NC: Duke University Press, 2012).

29 Morton Beiser, Samuel Noh, Feng Hou, Violet Kaspar, and Joanna Rummens, “Southeast Asian Refugees' Perceptions of Racial Discrimination in Canada," Canadian Ethnic Studies 33, no. 1 (2001): 46-69.

30 Phan, "Life in School," 558.

31 Clarry Lay and Thao Nguyen, "The Role of AcculturationRelated and Acculturation Non-Specific Daily Hassles: Vietnamese-Canadian Students and Psychological Distress," Canadian Journal of Behavioural Science 30, no. 3 (1998): 171-81.

32 Catherine L. Nolin, “Transnational Ruptures and Sutures: Questions of Identity and Social Relations among Guatemalans in Canada," GeoJournal 56, no. 1 (2002): 59-67.

33 Yen Le Espiritu, "Beyond the 'Boat People': Ethnicization of American Life," Amerasia Journal 15, no. 2 (1989): 49-67.

34 Yen Le Espiritu, Body Counts: The Vietnam War and Militarized Refugees (Berkeley, CA: University of California Press, 2014).

35 Xuân, focus group \#3, 28 April 2013.

36 Phủ, individual interview \#3, 23 May 2013.

37 An, individual interview \#8, 10 July 2013.

38 Hùng, focus group \#2, 23 March 2013.

39 Kimberly Kay Hoang, Dealing in Desire: Asian Ascendancy, Western Decline, and the Hidden Currencies of Global Sex Work (Berkeley, CA: University of California Press, 2015).

40 Minh, individual interview \#2, 15 May 2013.

41 Phủ, focus group \#4, 4 June 2013.

42 Hai, focus group \#2, 23 March 2013.

43 Thu, individual interview \#6, 10 June 2013.

44 Tam, individual interview \#4, 23 May 2013. 
45 Mai, focus group \#3, 28 April 2013.

46 Further analysis of this incident can be found over several articles in Linda Trinh Vô, ed., "Vietnamese Americans: Diaspora \& Dimensions," Amerasian Journal 29, no. 1 (2003).
Anh Ngo is a PhD candidate in the School of Social Work at York University. She may be contacted at anhngo@yorku.ca. 


\title{
The Vietnamese Refugee Crisis of the 1970 s and 1980s: A Retrospective View from NGO Resettlement Workers
}

\author{
ANNA N. VU AND VIC SATZEWICH
}

\begin{abstract}
This article examines the role of $N G O$ resettlement workers in refugee camps in Southeast Asia during the late 1970 s and 1980s. The workers offered psychological support to refugees whose lives were in turmoil, but they also helped them present themselves in ways that would be most attractive to Western host countries. This process involves both commission and omission. NGO resettlement workers sometimes actively guided refugees by giving them specific advice and training. At other times, they facilitated this endeavour by observing how refugees fit themselves into the selection categories of various states, but chose to remain silent in order to avoid jeopardizing the refugees' chances for resettlement.
\end{abstract}

\section{Résumé}

Cet article examine le rôle des travailleurs du secteur de réinstallation oeuvrant pour les ONG dans les camps de réfugiés en Asie du Sud-Est pendant la fin des années 70 et les années 8o. Les travailleurs ont non seulement fourni des soutiens psychologiques aux réfugiés dont la vie avait été bouleversée, mais ils les ont également aidé à se présenter aux pays d'accueil occidentaux sous des aspects qui seraient les plus favorables à attirer leur intérêt. C'était un processus qui impliquait des parts égales de commission et d'omission. Parfois les travailleurs du secteur de réinstallation oeuvrant pour les ONG ont activement guidé les réfugiés en leur fournissant des conseils et des formations spécifiques, tandis que d'autres fois ils ont choisi de les aider à atteindre leurs objectifs en observant passivement la façon dont les réfugiés tentaient de se faire conformer aux catégories de sélection de différents pays, afin d'éviter de mettre en péril leurs chances de réinstallation.

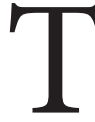
The Vietnamese refugee crisis that began with the Fall of Saigon in 1975 and the harsh reality of communist rule, ${ }^{1}$ which culminated in the mass exodus of "boat people" beginning in 1978, was a defining moment for the international community and for countries of resettlement. The UNHCR helped to negotiate a unique "orderly departure program"2 with the Vietnamese government and organized a number of international conferences in order to manage the crisis, ${ }^{3}$ and countries like the United States, Australia, and Canada developed new resettlement schemes in response to what was unfolding in the South China Sea. While some refugees returned to Vietnam in the 1990s as part of the Comprehensive Plan of Action negotiated with the Vietnamese government, ${ }^{4}$ before that many others were selected for resettlement by various governments after spending time in refugee camps in Thailand, Malaysia, the Philippines, Hong Kong, Singapore, and Indonesia. Over 1.6 million refugees were resettled between 1975 and 1997, mainly in Western countries. 5

The broad contours of the resettlement of Vietnamese refugees are now well known. ${ }^{6}$ Less well known, however, are the activities of "middle people" in the resettlement processnamely, the many Western volunteers and members of NGOS who staffed the refugee camps that were created for the Vietnamese and who provided comfort and aid to refugees and helped them to relocate to a safe third country. Occupying 
positions at what Steven Castles and Mark Miller call the "meso level" of the migration process, ${ }^{7}$ these workers navigated the space between receiving state selection and admission policies and the refugees who were seeking resettlement.

This article focuses on the men and women who worked with Vietnamese refugees in transit camps in Southeast Asia beginning in the late 1970 s and their perceptions of how refugees fit themselves into the selection categories of Western states. Data were collected on the basis of oral history interviews with these workers. This article examines how NGO resettlement workers sometimes merely observed the complex ways in which Vietnamese refugees negotiated the process of being accepted for resettlement, and how at other times they acted as direct facilitators in this process. It must be emphasized, however, that even choosing to "observe" rather than act had repercussions. To observe, but to remain silent about some or all of what one sees, is itself a choice. NGO resettlement workers were forced to make these decisions daily, and they realized that action (or inaction) would have profound implications for the future of these refugees.

\section{Theoretical and Conceptual Context}

International migration is arguably best understood from a systems perspective. ${ }^{8}$ This perspective emphasizes the interconnections between the macro-level social, political, and economic forces that lead people to leave their countries of origin and state policies that define who should be admitted as an immigrant or refugee, and the micro-level individual and household-level calculus involved with decisions to leave and where to move. It also points to the importance of the "meso-level" third-party intermediaries who facilitate the migration. The latter, described by Castles and Miller as the "migration industry," includes immigration lawyers and consultants, travel agents, labour recruiters, and people smugglers, as well as the representatives of voluntary agencies and NGOs that help migrants and refugees. ${ }^{9}$

At the macro level, state immigration policies normally contain clear-cut categories defining those it deems admissible and inadmissible. Most countries' immigration laws also specify particular sets of policies governing the selection and admittance of visitors, students, workers (with or without the right of permanent residence), family members, refugees, and the like. ${ }^{10}$ These categories tend to be precisely defined and mutually exclusive. As Bakewell argues, ${ }^{11}$ policy categories "are used to define those groups of people who are assumed to share particular qualities that make it reasonable to subject them to the same outcomes of policy. The policy will lay out how the organization concerned will interact with people who fall into a particular category; for example granting them legal rights or providing them with resources and services."12
These policies are further codified and made progressively more specific in immigration regulations and field processing manuals and guidelines issued to border control agents who are expected to implement policy. Visa issuance and other border control decisions essentially involve fitting individual cases into the boxes of the "admissible" categories within immigration policy. ${ }^{13}$ In this light, individuals are not, in some ontological sense, inherently "refugees," "migrant workers," or "permanent residents," but rather become so because they are defined as such by states. ${ }^{14}$

At the micro level, the real world of immigrants and refugees is not as tidy as policy categories imply. ${ }^{15}$ As the literature on transnationalism and diasporas has demonstrated, ${ }^{16}$ it is actually quite rare for individuals to completely cut their ties and relationships with their home countries, and they often move back and forth between their countries of origin and settlement. This calls into question the seemingly hard and fast distinction between "sending" and "receiving" countries. Moreover, individuals and households often have mixed motives for migration, and it can be difficult to ascertain whether individuals and households move for "economic" or "political" reasons. Though some countries like Canada now recognize "dual intent," insofar as they recognize that an individual may seek temporary admission but also have the longer-term goal of settling permanently, individual visa applicants are assessed on the basis of the rules governing the application category under which they are applying.

As Turton argues in his discussion of how "forced migration" is conceptualized, the distinction between "forced" and "unforced" migration is inherently problematic: ${ }^{17}$ "By trying to separate out the categories of migrants along a continuum of choice-free at one end and entirely closed at the other-... [various conceptualization] schemes are in danger of ignoring the most important quality of all migrants and indeed of all human beings: their agency."18

Turton is careful, however, to not completely dismiss the utility of the category of "forced migrant." Instead, he pleads for a better understanding of the point of view of refugees, or "forced migrants," their inherent humanity as "purposive actors," and "their active decision making: how they reach the decision to leave, what information is available to them when they make the decision; the way in which their journey is financed, the degree to which it is planned with a specific destination in mind; the extent to which they had prior contact with that country, etc. etc."19

Thus, if state border-control decisions involve fitting individual cases into immigration categories, individual migrants and refugees, through their agency, also try to fit themselves into the categories they believe the state is looking for by virtue of its immigration categories. As such, all
(C) Author(s), 2016. This open-access work is licensed under a Creative Commons Attribution-NonCommercial 4.0 International license.
Cette oeuvre en libre accès fait l'object d'une licence Creative Commons Attribution-NonCommercial 4.0 International. 
migrants - whether they apply as students, temporary workers, family members, permanent residents, or refugees-are "purpose actors" 20 who craft their biographies in ways that they believe will maximize their chances of being selected by the country in which they wish to settle. In so doing, they may selectively emphasize, de-emphasize, embellish, and modify aspects of their biographies, identities, and situations that they believe would favourably impress the country of their choice. Of course, the process of biography formation, or what Goffman called the "presentation of self in everyday life," ${ }^{21}$ can cross into misrepresentation and fraud where claimed identities, experiences, relationships, and attributes have little or no basis in reality.

In this context, third parties at the meso level also play a key role in this collaborative process of biography formation and categorization. Immigration lawyers and consultants sell advice to clients about how to best craft their biographies to meet their immigration-related objectives. People smugglers take advantage of individuals who are desperate to leave their countries of origin but who face difficulties in meeting a receiving country's rules for legal entry. In both cases, the expectation of financial gain helps to explain the activities and interests of these third parties. However, while NGO resettlement workers and volunteers who work with migrants and refugees are not necessarily motivated by the prospect of financial gain, they are often part of the informal processes that contribute to the system of biography categorization at both the state and individual level.

Individuals who work for the UNHCR are often called upon to initially screen refugee claimants and confirm aspects of their biography that make them eligible for their formal categorization as a refugee under the Convention definition of a refugee or protected person. ${ }^{22}$ Those who work for other NGOs may provide informal advice to individuals about what states are looking for, or what aspects of their biography they ought to emphasize. Some may simply observe how refugees craft their biographies, yet others may participate in subtle yet important ways such as by staying silent when they observe refugees crafting biographies to meet state-defined selection criteria.

\section{Data Collection}

Our data were collected through one-on-one interviews and questionnaires administered to 14 individuals who worked in different refugee camps in Southeast Asia in the 1970 s and 1980s. We located these former resettlement workers through social media sites (e.g., "Galang Camp" and "Galang Refugee Camp" Facebook groups) and through chain referral. Our participants included ten male and four female workers in several international and nonprofit organizations, including the International Catholic
Migration Commission (ICMC), Catholic Relief Services (CRS), Save the Children Fund (SCF), the United Nations High Commission for Refugees (UNHCR), and World Relief (WR). Their work in refugee camps involved advising refugees, administering health-care services, conducting basic screening, and providing educational training and cultural orientation to local volunteers. These local teachers in turn taught classes to refugees. Aside from these more obvious tasks, resettlement workers provided much-needed emotional support and encouragement, which was especially important for those who suffered from the disappointment of being rejected for resettlement.

Our interviewees now live in Indonesia, Uganda, the United Kingdom, and the United States. Many participants are now in their 6os, with a few in their 50 s and 7os. A number of them continue to be involved in some capacity with refugees and underprivileged or marginalized populations in their own country or internationally. ${ }^{23}$ Our respondents included both Westerners and non-Westerners. The interviewees are not of Vietnamese origin, but several of them speak the language fluently and thus were better able to understand the "lived experience" of the refugees they assisted.

Some of the interviews were conducted over the Internet and lasted between one and one-half to two hours. Several participants opted to give their answers in writing, and the completed responses were then sent back to us through email. We asked about the nature of their role as facilitators, their perception of the refugee situation, and the bureaucratic process of selection and resettlement of different Western countries. Their accounts of their experiences as resettlement workers were invaluable to us insofar as they gave us a window into how Vietnamese refugees negotiated the transition from camp life to resettlement abroad. It is important to note that our intention in this article is not to have resettlement workers "speak for" Vietnamese refugees. Rather, we are interested in understanding the experiences of resettlement workers and their interactions with Vietnamese refugees. As has been indicated, these interactions ranged from more active roles in helping refugees craft their biographies and personae, to more subtle interventions, sometimes involved simply remaining silent.

These workers are uniquely qualified to offer insights into this period in history, because they can speak about it with relative freedom. However, even 40 years after their resettlement, some refugees may be reluctant to talk about how they fit themselves into state-defined refugee selection categories lest they be accused of having deliberately misrepresented themselves and their situations to gain entry. In this way, the workers we have interviewed give their voices to those who cannot speak. 
These oral histories should, however, be treated with caution. As Abrams and Hamilton and Shopes argue, ${ }^{24}$ there is a distinction within oral history research between the collection of "facts" about the past and the collection of "memories" about the past. Oral history tells us as much about what happened in the past as it does about how individuals remember the past, or as Abrams puts it, the ways in which "people articulate subjective experiences about the past through the prism of the present." 25 For many of our interviewees, the time spent in transit camps remains one of their most important and meaningful life experiences. As George noted when asked about how this work has affected him, "It's a defining experience in my life and I'm very grateful for it. It's made me a better person-giving me a greater appreciation for a life experience that I probably would never have had. It's made my life much richer, much more interesting, so I'm very grateful for that experience."

George's remarks emphasize his evolution as a person, which he feels would not have been possible in any other context. Once again, it is important for researchers to be aware that personal narratives cannot always yield results that meet the highest standards of reliability and verifiability, especially when such accounts are retrospective. This is even more likely to be the case when respondents' selfconcepts are closely connected to their roles as resettlement workers. Therefore, they may be inclined to focus on situations that allow them to offer aid and comfort to refugees, and even help them to subvert the rules, rather than on situations in which they acted as informal gatekeepers for Western countries. This of course is a much less sympathetic role. All of these limitations must be taken into account, but nevertheless these narratives are immensely valuable in their own terms.

\section{Resettlement Workers and the Crafting of Biography}

The academic literature on life in refugee transit camps often focuses on the psychological stresses and strains of living in camps and waiting for resettlement. One view tends to paint a picture of refugees in transit camps as lacking human agency, ${ }^{26}$ and as largely passive in the face of processes over which they have no control. Descriptions of camp life for Vietnamese refugees emphasize boredom, uncertainty, and feelings of helplessness among refugees in transit camps. ${ }^{27}$ Referring specifically to the Vietnamese in refugee camps in the 1970s, Kelly argued, "The Vietnamese role was passive: things were done to them; they did very little. And, like much of camp life that followed, they stood in interminable lines waiting for something to happen."28

In another study of camp life for Vietnamese refugees in the Philippines, Hong Kong, and Japan, Knudsen describes life as "meaningless, uncertain, waste of time, boring and passivizing." 29 This picture of camp life for Vietnamese refugees is further reinforced by Chan and Loveridge's research on Kai Tak camp near Hong Kong in the late 1970s.30 Though they point out that there are significant differences in various camps based on context, they argue that in Kai Tak camp, the Vietnamese experienced intense culture shock, because the camp was located so close to the developed, teeming metropolis of Hong Kong. In addition to culture shock, they assert that feelings of helplessness and passivity were the defining features that characterized camp life at that time. As they explain, the refugee is

thus reduced to impotence, either by having no control over what is done to him in the name of institutional efficiency, or for him under the banner of charity. In either case, the refugee is involved more as a spectator than an autonomous individual, a precise parallel in psychological terms of the powerlessness so many experienced being washed around at sea on the journey from Vietnam. The only real difference is that being "at sea" is now metaphorical rather than literal. While there clearly exist many understandable reasons for the all-pervading depression, there would seem a case for Seligman's (1975) notion of learned helplessness where there is no relationship between the efforts of the person to receive reinforcement and the outcomes of those efforts. ${ }^{31}$

This view of refugee camp life at the time, which may have been tainted by older colonial-inspired stereotypes of the Vietnamese as passive, stoic, and "incapable ... of sustained thought or action," 32 stands in rather stark contrast to the view of camp life painted by those who analyze the experiences of European displaced persons during and after the Second World War. ${ }^{33}$ It requires revision insofar as the NGO resettlement workers with whom we spoke emphasized the ways in which the refugees they observed, and with whom they interacted, consciously crafted their biographies to meet the selection criteria used by national immigration officials, made creative use of informal social networks and transnational ties to develop migration strategies that reflected their own and their family members' long-term resettlement goals.

Upon their arrival in the country of first asylum in the region, many refugees lacked proper documentation to help establish their background and personal identity. This was not uncommon as a result of the chaotic and dangerous circumstances involved in their exit from Vietnam. However, this presented a major challenge for both the authorities and the refugees themselves when a complex system of paperwork was put in place to select refugees for resettlement to one of the safe third countries. Refugees thus faced the daunting task of having to reconstruct their personal histories in ways that sounded credible and convincing to
(C) Author(s), 2016. This open-access work is licensed under a Creative Commons Attribution-NonCommercial 4.0 International license.
Cette oeuvre en libre accès fait l'object d'une licence Creative Commons Attribution-NonCommercial 4.0 International. 
authorities (i.e., immigration officials) who were, in effect, in charge of their fate. Conversely, immigration authorities had to sort through issues of credibility in order to assess whether the person admitted fit into their predefined selection criteria. Mike remembered the broad contours of the process as "like a lottery of arbitrary justice within a massive labyrinth of deception."

Our interviews with resettlement workers revealed that refugees were adept at exercising at least some control over their destiny. Workers perceived that refugees used a number of strategies to make themselves appear more attractive to the country they hoped would accept them. This, of course, depended to a great extent on how a given country categorized different types of refugees. Generally, the most important criterion for acceptance by different countries, particularly the United States (which was also the first choice for many of the refugees), ${ }^{34}$ was immediate family reunification. This meant that in order for refugees to be accepted for resettlement quickly, they needed to show that they had other family members who were already living in the United States. Unaccompanied minors represented the second category. This included children under 18 who were in the camps alone. The third category included former South Vietnamese military personnel as well as those who worked for the us government during the war. Those with distant relatives in the United States were considered next. Lastly, refugees without any connection to the United States, but who had been rejected by at least two other countries, were also considered for resettlement. ${ }^{35}$

Canada's policies were similar to those of the United States-that is, Canada also considered family reunification as a priority, although our respondents indicated that Canadian authorities placed more emphasis on age, English language acquisition, health, and the ability of the refugees to be integrated into the workplace. ${ }^{36}$ In other words, in order to be accepted by Canada, it was particularly important that refugees could demonstrate their employability. As Mike put it, "The Canadians took the best English speakers ... it was generally perceived that Canada accepted the 'cream of the crop' of the refugees who did not have family connection abroad."

Canada developed its own innovative private sponsorship program to help with the refugee crisis. ${ }^{37}$ The program was formally introduced in 1979 and involved the application of a "matching formula"-that is "the government would sponsor one refugee for each one sponsored privately." 38 In other words, church groups or groups of five or more adult Canadians would be allowed to sponsor a refugee or a refugee family directly. This sponsorship involved providing resettlement assistance and support to refugees for their first year in Canada. 39
Australia, while also focused on nuclear family relations, accepted young families as well as well as (often) unaccompanied women. $4^{\circ}$ Despite these clearly articulated selection criteria, one of our interviewees' main memories of the Australian selection system was that it was informally shaped by gendered understandings of resettlement. Some reported that being a single young female was considered an asset. "The Australians had a reputation for accepting young single women," recalled Doug. "I heard it expressed that the women would either find a mate or a job rather easily in Australia, so they would not put a strain on local resources." Mike's recollection was that "Australia accepted the most attractive women." As previously noted, oral history data can be problematic because it is difficult to verify whether respondents are drawing conclusions based on fact or their perceptions and memories of the situation.

However, the work of James Coughlan and Adrian Carton lends support to the assertions of the above-mentioned respondents. ${ }^{41}$ As Coughlan notes, "For a short period during 1978-1979 some Australian immigration officers working in Malaysia deliberately split families in order to select young single females for entry to Australia."42 Carton observes that because females immigrants are considered to be non-threatening, they help to defuse the moral panic that is often associated with refugee crises. ${ }^{43}$

Other smaller, European countries, especially those that make up the Scandinavian Peninsula, 44 and New Zealand 45 accepted smaller numbers of refugees. Some, like Denmark, did not have a clear system of selection criteria. Instead, their policies were more often based on the "need to fill quota" basis. ${ }^{46}$ Although these countries accepted very few refugees, they often took the more difficult cases, such as individuals with serious illnesses or disabilities, victims of sexual assaults, unaccompanied minors with no family connection, as well as the elderly with no family. 47

The brief discussion above of immigration policies in various countries and the constraints that these policies impose on refugees highlights the need for refugees to craft their biography and identity in ways that help them meet these criteria. The framing and reframing of one's past life often might involve the creation of strategic family connections where no such connections actually exist. This of course requires great ingenuity and creativity, but as we will see, it can also lead to unintended and unanticipated consequences.

George, one of our respondents, was an American worker in a refugee camp in Thailand who later married a Cambodian woman. He shared a story that spoke to the need for family connections to meet American selection criteria. He explained that his wife's family had a male friend in California. This man had lost his wife in the genocide, and coincidentally, his wife's mother had also lost her husband:
(C) Author(s), 2016. This open-access work is licensed under a Creative Commons Attribution-NonCommercial 4.0 International license.
Cette oeuvre en libre accès fait l'object d'une licence Creative Commons Attribution-NonCommercial 4.0 International. 
What they tried to do was to show that this man was the husband of my wife's mother. So they basically made up the story. They somehow convinced the officer that this was a true story, even though it wasn't. My wife's mother and sister were accepted by the us agency to reunify with the man who'd already been accepted for resettlement. So there were a lot of these stories, dealing with establishing family reunification-that someone they knew who had already been resettled was a family member. The interviewers gave priority to those families rather than somebody who had nobody in the us.

The attempt to construct family connections also involved changing names. As Daniel said, "Some [refugees] intentionally falsified names and documents in the hope of getting accepted by a certain country because 'the new names' had relatives in that country." NGO resettlement workers also saw that changing one's age was another common practice for the refugees, because, according to Emmy, "the older the refugees were, the more problems they faced in being accepted by different countries." Another example of reframing biographies was offered by Michael, who spoke of what he remembered as the "strange" case of a "brother and sister."

There was a young man and woman. They had already been accepted to leave for the Us. So I was interviewing them, not for their admission interview, but the resettlement interview. There were two interviews: one to see if they qualify, then after they were accepted, we do a second interview for resettlement placement. So we know they were already going to go to the us, but we had to prepare their bio (language, education, etc.) to place them somewhere. And so there's this brother and sister, and she was pregnant, and they appeared to be unusually close, like she was almost leaning on him.

It soon became evident that they were not brother and sister, but in fact, girlfriend and boyfriend. However, this couple was afraid to admit that they had misrepresented themselves, for fear of invalidating their application for resettlement. And as Michael was aware, there is a huge difference between what one knows (or suspects) and what can be proven:

We were trying to figure out where's the father of the child-it always became a little fuzzy. At one point, they said she was raped by pirates-so tragic. It turned out they're boyfriend and girlfriend: they weren't married, and he got her pregnant, and he lied to say that he's her brother, because he was afraid they'd be separated-she may go to one country and he may go to another. And we said, why didn't you just tell the truth, and they said they were afraid. At that point it didn't matter-they were already accepted and we just tried to place them, but they were so afraid that we would separate them.

Establishing family connections is especially important in successful relocation. However, this effort is complicated by important differences in Eastern and Western cultures, ${ }^{48}$ which may have legal ramifications. Michael told of a situation of "a man and two women with ten children" he remembered dealing with where they steadfastly adhered to a story, in spite of its obvious inconsistencies, because they were aware of potential legal problems in the West:

The children all looked alike and were very similar in age. In fact, some of the kids looked like they were the same age as each other. They claimed that a man and one woman had all of these children, and the other woman was a sister of the wife with no husband, and living with them. And no matter what, they wouldn't change their story. I had no way to prove it, but I believe that he had children by both women. It was a polygamous affair, which was not uncommon in Vietnam, especially for older people. But they knew that if they admitted to polygamy, they'd be rejected by the us, because that's against the law. And so no matter what, they wouldn't change their story.

Thus, as we can see, part of the legacy of the war is the hiding of identity. One's second wife is transformed into one's sister-in-law, and one's lover is reconfigured as a brother. The transformation of one's biography and family relationships is imperative if one is to meet the most important aspect of the selection criteria-family reunification. Michael, the resettlement worker who described the situation outlined above, was aware that the account offered was probably untrue, but decided not to make an issue of it since to do so would jeopardize the family's chances of being accepted. As has been noted, to choose to do nothing or say nothing is also a form of facilitation. In this case, Michael chose not to act because of his knowledge of structural requirements in Western countries might place their resettlement in jeopardy.

\section{Informal Social Networks}

Another strategy designed to enhance one's chances of survival involves the exchange of information through informal networks -in particular with those who have already been screened by officials. Gaylord talked about the resourcefulness of the refugees: "There were daily rumours (in Galang) about the moods of the interviewers, which interviewer to avoid on a certain day, even which clothing colour seemed to be getting the most acceptances. They also knew ways of getting rejected by countries they did not wish to go to (like Canada, because it was considered too cold)."
(C) Author(s), 2016. This open-access work is licensed under a Creative Commons Attribution-NonCommercial 4.0 International license.
Cette oeuvre en libre accès fait l'object d'une licence Creative Commons Attribution-NonCommercial 4.0 International. 
Gaylord's story shows how refugees were not passive in the interview process. In fact, they would sometimes exercise agency by rejecting an offer to resettle in a particular country rather than the reverse. Through the sharing of information, they knew that if they could not settle (for whatever reason) in two countries to which they had applied, they would then become eligible for admission to the us. For some refugees then, the question became "How can I make sure that I will not be able to resettle in country A or country B?" Sometimes a vehement "No!" would suffice when, at the end of the interview, the refugee would be asked, "Would you like to go to Canada?"

Thus, being "aware" was very important, and one's level of awareness increased the longer one stayed in refugee camps. Michael, whose job was to "pre-screen" refugees for their interviews with us immigration observed, "A lot of the strategies that people used to make themselves more acceptable was awareness, which, over time, when you spent more time in the camp and you tried and you failed, you become more aware of which country had which criteria and you tried to meet them."

As can be expected, information shared among refugees in the camps was primarily about the selection process of different Western delegations. Doug shared with us his recollection of refugees in both Malaysia and Indonesia-two of the refugee camps in the region in which he worked throughout the 1980s:

Rumours fuelled the camp. If someone was accepted or refused by a delegation, everyone wanted to know what questions were asked and how they were answered. I think all the refugees denied ever cooperating with or having anything to do with the communist government. There were lists of questions and answers that they passed among themselves, very often memorized in order. The delegations were aware of this and would occasionally ask questions out of order to trip up refugees. We really just focused on teaching them English and preparing them for when they would go on to whichever country accepted them.

As Doug's account shows, the officials of various NGOS who helped to select refugees for resettlement were not unaware of the refugees' efforts to make themselves appear to "fit" into the categories that made them eligible for resettlement. Though they no doubt recognized that virtually all of those who were living in the camp were genuine refugees, they nonetheless had to balance their own emotions over the trauma individuals experienced with the need to maintain the integrity of their respective selection system. As a result, they had to continue to revise their selection strategies in order to stay ahead of the refugees' efforts to exercise agency.
As previously mentioned, having military connections to the former South Vietnamese Army increased one's chances of successful relocation in the us. But how could this be established when often people had no documents? We have seen, quite understandably, that refugees were perceived by resettlement workers as having few qualms about the creation of a fictitious world. Michael describes how this was done:

Some had documents, but a lot didn't. We had to interview them to build their profiles. The story was plausible that they might have been in the army. A lot could tell you where they were, what their unit was. You could tell they were military people by the way they talked, the way they held themselves-their stories were very authentic. But then there were the grey areas. Of course people began to tell each other. How did the interview go? What did they ask?

Michael further explains that the exchange of information began to take on a structured and systematic form: "We found that at one point, they were having classes in the barracks, how to pass the test. They learned what kind of questions. So, how many bullets in an MC 16, or what's the name of the basic training camps, or who is the commander of the 25th Division. And so we began to find out when you interviewed people, they were all giving the same story ... people are going to do what they feel they have to do."

Organization and control of information is by definition one of the strongest forms of exercising one's agency. The dissemination of such information to those in one's cohort, even in these difficult circumstances, demonstrates a refusal to be defeated by events. We have already seen that even rejection may involve a careful consideration of available knowledge.

\section{Transnational Exchanges}

To achieve their resettlement objective, NGO resettlement workers also observed that refugees also relied on transnational exchanges. Transnational connections are often understood as part of a process in which individuals form multiple social, economic, and cultural relations between their country of origin and country of resettlement (as well as other countries). ${ }^{49}$ However, for the Vietnamese refugees, these connections began much earlier. As soon as the refugees arrived in the camp, they would be sure to communicate (by letter) with family members. They would ask their advice about the various government immigration policies and programs, the resettlement process in general, and family members' prior experiences with camp life. These letters would also serve to demonstrate that the refugee had family connections in a safe third country, which would presumably aid in family reunification. Thus, the advice
(C) Author(s), 2016. This open-access work is licensed under a Creative Commons Attribution-NonCommercial 4.0 International license.
Cette oeuvre en libre accès fait l'object d'une licence Creative Commons Attribution-NonCommercial 4.0 International. 
that refugees received from overseas also played a role in their overall strategies of getting accepted by a country in which they were most interested in resettling.

Vera, who worked as an English teacher in Galang Refugee Camp in Indonesia from 1986 to 1996, noted that refugees put effort into "making a good record in the camp by working, volunteering, studying, not getting involved in vices, etc." Daniel, a former English teacher, explained that keeping themselves active "was regarded by delegations as persons who wanted self-improvement in their lives," which of course enhanced their chances of being accepted for resettlement.

Michael describes how the country-to-country exchange of information could even change the dynamics of relocation. As has been mentioned, many of the refugees chose the United States as their top country of resettlement. They were thus willing to spend the time waiting to be accepted. Refugee workers, on the other hand, found this frustrating because, in their view, the goal should be for refugees to get out of the camp as quickly as possible.

We tried to tell the refugees, "Look, you don't meet the criteriago apply to Canada." A Canadian just told me they're frustrated because they can't fill their quota. The Australians were frustrated because they were trying to be generous and the refugees go "I don't want to go to your country. Please reject me, because I know that the Americans were willing to consider me if I were rejected twice."

But then I would have this complication with the refugees and I'd say, "Look, don't do that. You're just going to delay your departure. Go! Your objective should be to get out of here. Everybody is going somewhere-just go! Canada is a nice country. Australia is a nice country."

"Oh, no, no, no, Canada is too cold, and I don't know anybody in Australia." Or they would say, "I don't want to go to Germany because they don't speak English."

"Oh, oK, well, you don't speak English either."

"Yes, but I want to go to America."

However, once refugees began to hear stories from family abroad, they began to change their mind. Family connections began to emerge in countries other than the United States. Michael continues,

Another thing is once people began to hear stories from relatives and friends in Western countries (other than the us), the whole equation changed. People started to sign up for Canada. They had a friend there. They had a brother there. They heard it's not so bad. They had socialized medicine, but in America, no. So once the word got back at least it's not so bad in Canada, then people didn't mind going there.
There were people in Norway who got picked up by the freighters and the word got back that things were pretty good in Norway, because they're a welfare state.

Following such advice, however, does not always result in the desired outcome. Michael recalled the situation of a young man he met in the United States many years after resettlement. This individual tried for many years to sponsor his parents, but he was unable to do so because he had created a new identity during his time in the refugee camp. He had given himself a new identity in order to appear to be a member of another family. As a result of this reconfigured identity, he and his biological family had to suffer the consequences-they could never be reunited.

This course of action may have seemed rational at the time, but as Mike put it, it is not always a good idea to follow the advice of others: "I would advise them to follow the guidelines set by UNHCR and the resettlement countries and ignore the bad advice some refugees received from their relatives overseas. Just answer some questions accurately and truthfully."

This is not to say that all refugees embraced advice uncritically. For example, one young man who had received a copy of the us immigration guideline (now outdated) noticed that communists and homosexuals were barred from entering the United States. Of course the part about communists would be clear to him, but he did not understand the meaning of the word homosexual. He asked a resettlement worker about it and was told it didn't apply to him and not to worry.

The response from our interviewee above indicates how NGO resettlement workers choose to exercise their own judgment in certain cases. Our data demonstrate that this is true in a variety of situations, especially those that might jeopardize the refugees' chances of resettlement. On several occasions, resettlement workers had to deal with the issue of "unaccompanied minors," who may have been disguising their real ages in order to avoid conscription. ${ }^{\circ}$ One respondent explained, "We had a lot of young men fleeing for that reason. So why wouldn't they lie and say I'm 17 instead of I'm 20. I saw a lot of that-so do we blame them? At the same time, we had our own criteria. We don't have criteria for young men fleeing conscription-that's not in the book. We had criteria for unaccompanied minors to make sure that children get out of refugee camps."

As this respondent has indicated, resettlement workers did not always go by the book, and "the book" does not necessarily include instructions on dealing with real-life situations. They must constantly deal with ambiguity, and this forces them to exercise their own judgment.

Cheryl, who had been a nurse in the Galang refugee camp in Indonesia, explained how she often had to balance
(C) Author(s), 2016. This open-access work is licensed under a Creative Commons Attribution-NonCommercial 4.0 International license.
Cette oeuvre en libre accès fait l'object d'une licence Creative Commons Attribution-NonCommercial 4.0 International. 
humanitarian concerns with the need to at least appear to be following prescribed rules:

For refugees with mental illnesses, I organized evaluations by a psychiatrist who was based in Bangkok and came periodically to Galang. He would bring medication that was not allowed by the camp authorities and leave it with me so I could administer it to the refugees. Once they were stabilized, I would organize a repeat evaluation by the psychiatrist so that the refugees could apply for migration to various countries. On a couple of occasions, we-the psychiatrist and I-asserted that refugees who had serious mental illness were suffering from post-traumatic stress disorder or postpartum depression, both of which did not preclude migration to many countries-in order to allow them the chance to apply for migration.

Thus, these NGo resettlement workers became adept at navigating difficult situations, and facilitated refugee efforts to meet state-defined selection criteria. Their role as mesolevel facilitators, as the data indicate, involved much more than applying rules and offering specific information. It involved evaluation, interpretation, and decision-making on a subtle and nuanced level.

\section{Conclusion}

From the state's point of view, immigrant and refugee selection involves "marrying" general immigration rules and criteria to individual cases. Immigration officials, including those charged with initially screening and then selecting refugees for resettlement, must apply those rules and "fit" them to real-world cases. From the perspective of refugees, the policy categories and preferences of different countries become the targets they must hit in order to resettle. Refugees must in turn craft their biographies and present the situation of themselves and their family members in particular ways in order to meet the selection criteria of a particular state.

NGO resettlement workers play intermediary roles between the macro and micro levels of the migration process insofar as they variously observe, help, or hinder how refugees negotiate the bureaucratic selection process within refugee camps. In our case, some formally and informally helped refugees try to "fit" their biographies to the selection criteria of the country in which they were seeking resettlement. Others observed what was going on and stayed silent, even when they thought or suspected that the refugees they were in contact with were deliberately presenting themselves in ways that did not reflect the reality of their family or other circumstances. The fact that they stayed silent when they could have whispered their observations to local immigration authorities, or even write formal reports on what they were observing, arguably reflects their broader understanding of the challenges refugees faced in meeting policy criteria. Of course, it is also possible that some NGO resettlement workers did in fact inform immigration officials in specific countries of what they were observing in the camps and how refugees were crafting stories to make them acceptable. Some of our respondents may in fact have done this, but it is easy to see how, in retrospect, they might not want to emphasize their role in obstructing the resettlement of refugees decades earlier.

Today, much of the public and political discussion focuses on "bogus" refugees: economic migrants who deliberately manipulate internationally recognized refugee protection norms to bypass immigrant selection systems..$^{51}$ Though the NGO resettlement workers we interviewed recounted stories of embellishment, telling untruths, and the crafting of biographies or relationships, this does not alter the fact that the people with whom they were working were genuine refugees. Crafting biographies and using social networks and transnational ties to gather information about what different countries were "looking for" are normal parts of the migration process. ${ }^{52}$ They also reflect the agency that refugees possess, even in highly stressful and constraining circumstances, when meeting a bureaucratic category can mean the difference between a bright or bleak future. Data in this article should not, therefore, be interpreted as evidence that Vietnamese were not genuine refugees or in need of resettlement, or that there was something inherently manipulative about their strategies to find a suitable country for resettlement.

While the "rational" decision-making of refugees may seem irrational to others, we suggest that, when examining the situation of refugees, aspects of culture and personal history should be taken into consideration. The ordeal that Vietnamese refugees went through-from wartime experiences to planning their escape to making it in transit camps-illustrates that telling the truth may very well result in tragedy. Ultimately then, the aim is to survive and to prosper, for oneself and for one's family.

Though refugee camps are sites of profound despair and suffering - and places where those who await resettlement are buffeted by processes beyond their control-this does not mean that refugees are completely powerless in these circumstances. The picture of Vietnamese refugee camp life that has been painted in some of the literature needs to be modified through better understanding of refugees' limited forms of agency. Though they do not control the selection criteria of various counties, and are subject to policies and decisions within camps that are beyond their control, they do have some ability to try to achieve settlement outcomes that are most desirable from their point of view.
(C) Author(s), 2016. This open-access work is licensed under a Creative Commons Attribution-NonCommercial 4.0 International license.
Cette oeuvre en libre accès fait l'object d'une licence Creative Commons Attribution-NonCommercial 4.0 International. 


\section{Notes}

1 The communist takeover of Vietnam meant that anyone with connections to the ancien régime or to the Americans faced oppression and persecution. This political backlash necessitated a mass exodus of the "boat people" who risked their lives at sea in search of freedom and a better life for themselves and their family in the West.

2 This program was created to allow for the immigration of Vietnamese to the United States and other countries. The aim was to help put an end to the human tragedy by providing a safe and legal alternative for the Vietnamese to leave their homeland.

3 UnHCR, The State of the World's Refugees, 200o: Fifty Years of Humanitarian Action (New York: Oxford University Press, 200o).

4 More information on this can be found in W. Courtland Robinson, "The Comprehensive Plan of Action for Indochinese Refugees, 1989-1997: Sharing the Burden and Passing the Buck," Journal of Refugee Studies 17, no. 1 (2004), http://www.jhsph.edu/research/centers-and-institutes/center-for-refugee-and-disaster-response/publications_tools/publications/additional_pdfs/Robinson2004Indochinese_refugees.pdf.

5 UNHCR, State of the World's Refugees, 2000.

6 W. Courtland Robinson, Terms of Refugee: The Indochinese Exodus and the International Response (London: Zed Books, 1998).

7 Stephen Castles and Mark Miller, The Age of Migration: International Population Movements in the Western World, 3rd ed. (London: Guilford, 2003).

8 Alan Simmons, Immigration and Canada: Global and Transnational Perspectives (Toronto: Canadian Scholar's, 2010); Castles and Miller, Age of Migration.

9 Castles and Miller, Age of Migration.

10 Augie Fleras, Immigration Canada: Evolving Realities and Emerging Challenges in a Postnational World (Vancouver: UBC Press, 2015); Simmons, Immigration and Canada.

11 Oliver Bakewell, "Research beyond the Categories: The Importance of Policy Irrelevant Research into Forced Migration," Journal of Refugee Studies 21, no. 4 (2008): 432-53.

12 Ibid., 436.

13 Vic Satzewich, Points of Entry: How Canada's Immigration Officers Decide Who Get In (Vancouver: UBC Press, 2015).

14 Nandita Sharma, “The 'Difference' That Borders Make: 'Temporary Foreign Workers' and the Social Organization of Unfreedom in Canada," in Legislated Inequality in Canada: Temporary Labour Migration in Canada, ed. Patti Tamara Lenard and Christine Straehle, 26-47 (Montreal and Kingston: McGill-Queen's University Press, 2012).

15 Peter Nyers, Rethinking Refugees: Beyond States of Emergency (New York: Routledge, 2006).

16 Robin Cohen, Global Diaspora (London: Routledge, 2008); William Safran, "Diaspora in Modern Societies: Myths of Homeland and Return," Diaspora: A Journal of Transnational Studies 1, no. 1 (1991): 83-99; Luin Goldring and Sailaja Krishnamurti, Organizing the Transnational: Labour, Politics, and Social Change (Vancouver: UBC Press, 2007).

17 David Turton, “Conceptualising Forced Migration" (presentation, Refugee Studies Center's International Summer School in Forced Migration, University of Oxford, July 2003).

18 Ibid., 9-10.

19 Ibid., 12.

20 Ibid.

21 Erving Goffman, The Presentation of Self in Everyday Life (Garden City, NY: Doubleday, 1959).

22 For more on this, please consult UNHCR, Convention and Protocol Relating to the Status of Refugees, http://www .unhcr.org/protect/PROTECTION/3b66c2aa1o.pdf.

23 We were saddened to learn of the death of one of the respondents. This individual has been integral to the success of our project, because without his help, we would not have been able to contact our other respondents. His eagerness to share his experiences with us has greatly enriched our research, and we will always be grateful.

24 Lynn Abrams, Oral History Theory (London: Routledge, 2010); Paula Hamilton and Linda Shopes, "Introduction: Building Partnerships between Oral History and Memory Studies," in Oral History and Public Memories, ed. Paula Hamilton and Linda Shopes, vii-xvii (Philadelphia: Temple University Press, 2008).

25 Abrams, Oral History Theory, 7.

26 Mustafa Emirbayer and Ann Mische, "What Is Agency," American Journal of Sociology 103, no. 4 (1998): 962-1023.

27 Kwok B. Chan and David Loveridge, "Refugees 'in Transit': Vietnamese in a Refugee Camp in Hong Kong," International Migration Review 21, no. 4 (1987): 745-59.

28 Gail Paradise Kelly, From Vietnam to America: A Chronicle of the Vietnamese Immigration to the United States (Boulder, co: Westview, 1977), 81.

29 John Christian Knudsen, "Boat People in Transit: Vietnamese in Refugee Camps in the Philippines, Hong Kong, and Japan," Bergen Occasional Papers in Social Anthropology 31 (1983): 170.

30 Chan and Loveridge, "Refugees 'in Transit."

31 Ibid., 754.

32 Karl Ashoka Britto, Disorientation: France, Vietnam, and the Ambivalence of Interculturality (Hong Kong: Hong Kong University Press, 2004), 94.

33 Wsevolod Isajiw, Yuri Boshyk, and Roman Senkus, The Refugee Experience: Ukrainian Displaced Persons after World War II (Edmonton, AB: Canadian Institute of Ukrainian Studies, 1992).

34 The preference for going to America has its origin in the Vietnamese language. As a result of the outcome of the mass evacuation at the end of the war and the subsequent resettlement of those evacuees in America, the term $\bar{u} i$ $M \tilde{y}$ (going to America) evolved to signify ūi vượt biên (to escape). Thus, escaping generally means going to America.
(C) Author(s), 2016. This open-access work is licensed under a Creative Commons Attribution-NonCommercial 4.0 International license.
Cette oeuvre en libre accès fait l'object d'une licence Creative Commons Attribution-NonCommercial 4.0 International. 
35 Irene Bloemraad, Becoming a Citizen: Incorporating Immigrants and Refugees in the United States and Canada (Los Angeles: University of California Press, 2006), 215.

36 Ibid.

37 Freda Hawkins, Critical Years in Immigration: Canada and Australia Compared (Montreal and Kingston: McGillQueen's University Press, 1989).

38 Michael Enright, “The Vietnam War: Canada's Role, Part Two: The Boat People," свс Radio, 30 April 2015, http:// www.cbc.ca/radio/rewind/the-vietnam-war-canada-srole-part-two-the-boat-people-1.3048026.

39 Citizenship and Immigration Canada, Summative Evaluation of the Private Sponsorship of Refugees Program, April 2007, http://www.cic.gc.ca/english/resources/evaluation/ psrp/psrp-summary.asp\#s1.o.

40 Hawkins, Critical Years in Immigration; James E. Coughlan, "International Factors Influencing Australian Government's Responses to the Indochinese Refugee Problem," Vietnam Generation 3, no. 2 (1991): article 8; Adrian Carton, "Symbolic Crossing: Vietnamese Women Enter the Australian Consciousness, 1976-1986," in Working Papers in Australian Studies, ed. Kate Darian-Smith, 57-84 (London: Sir Robert Menzies Centre for Australian Studies, 1994).

41 Coughlan, "International Factors."

42 Ibid., 15.

43 Carton, "Symbolic Crossing," 64-5.

44 Howard Adelman, "The Indochinese Refugees in Sweden," Refuge 2, no. 4 (1983): 10-11; Vad Jfnsson and Heidi Petersen, "Denmark: A National Welfare State Meets the World," in Immigration Policy and the Scandinavian Welfare State,
1945-2010, ed. Grete Brochman and Anniken Hagelund, 97-148 (London: Palgrave MacMillan, 2012); Carol Dalgish, Refugees from Vietnam (London: Palgrave Macmillan, 1989).

45 Trung Tran, "Vietnamese: Culture, Language and Work," Te Ara: The Encyclopedia of New Zealand, updated 13 October 2014, http://www.TeAra.govt.nz/en/vietnamese/ sources.

46 See Jfnsson and Petersen, "Denmark," 112.

47 Adelman, "Indochinese Refugees in Sweden," 10.

48 James Freeman, Hearts of Sorrow: Vietnamese-American Lives (Stanford: Stanford University Press, 1989).

49 Vic Satzewich and Nikos Liodakis, "Race" and Ethnicity in Canada: A Critical Introduction, 3rd ed. (Don Mills, on: Oxford University Press, 2013).

50 During the late 1970s, Vietnam and China were engaged in a border war, young men (18 years of age and older) faced the possibility of being drafted, and understandably, most were inclined to do anything that would allow them to avoid this.

51 Frances Henry and Carol Tator, The Colour of Democracy: Racism in Canadian Society, 4th ed. (Toronto: Thomson Nelson, 2010).

52 Turton, "Conceptualising Forced Migration."

Anna N. Vu recently completed a PhD at McMaster University. The author may be contacted atvun3@mcmaster.ca.

Vic Satzewich is professor of sociology at McMaster University. The author may be contacted at satzewic@mcmaster.ca. 


\title{
The Indochinese Refugee Movement and the Subsequent Evolution of UNHCR and Canadian Resettlement Selection Policies and Practices
}

\author{
MICHAEL CASASOLA ${ }^{*}$
}

\begin{abstract}
The Indochinese refugee movement cast a long shadow over subsequent resettlement operations. UNHCR has since asserted greater leadership, with resettlement becoming more individually focused and globally diverse, but also more complex. Canadian policy has also evolved to become increasingly focused on protection and supportive of UNHCR's durable solution activities.

This article seeks to compare UNHCR and Canadian resettlement selection policy and practice in place during the time of the Indochinese movement up to mid-2015. It highlights key elements in the evolution of UNHCR and Canadian resettlement policy and the factors behind them. It also identifies aspects of the Indochinese movement that are relevant to contemporary refugee policy.
\end{abstract}

\section{Résumé}

Le mouvement indochinois des réfugiés a exercé une influence profonde sur les initiatives subséquentes de réinstallation. Le HCR s'est affirmé davantage à la suite en tant que chef de file dans ce domaine, avec une approche à la réinstallation de plus en plus individuelle ainsi que diversifiée à l'échelle mondiale, mais aussi plus complexe. Les politiques canadiennes ont également évolué vers la protection comme principe fondamental, ainsi que le soutien des solutions durables promulguées par le HCR.
Cet article a pour objectif de comparer les politiques et pratiques de sélectionnement en matière de réinstallation de la part du HCR et du Canada à partir de l'époque du mouvement indochinois jusqu'à la première moitié de l'année 2015. Il souligne les éléments clés dans l'évolution des politiques et pratiques de réinstallation de la part du HCR et du Canada, ainsi que les facteurs qui les ont influencés. Il identifie également les aspects du mouvement indochinois qui sont pertinents aux politiques contemporaines en matière de réfugiés.

\section{Importance of the Indochinese Movement for Resettlement Internationally and for Canada}

$\mathrm{R}$ esettlement is an important part of Canada's response to the global refugee population. Canada has always been an immigration country, but the Immigration Act of 1976 for the first time explicitly included the goal of "upholding Canada's humanitarian tradition by welcoming refugees." The structure of Canada's refuge programs was set out in the Act, which also ensured the engagement of Canadian civil society in resettlement through the establishment of a private sponsorship of refugees (PSR) program. However, Canadian resettlement has undergone a series of revisions and updates from the time it came into force in 1978 until mid-2015. The changes were sometimes linked to larger reform measures, but at other times made in isolation.

* The views expressed in this article are those of the author and do not necessarily reflect the views of UNHCR. 
The refugee protection environment has undergone continuous change over this same period, with new challenges in forced displacement, a litany of new conflicts, entrenchment of conflicts that began decades ago, and the increased inability to find solutions. Resettlement has been presented as one means to address some of these challenges. It has also been presented in some schemes as a legal pathway to respond to mixed migration flows.

Resettlement functions as a tool of protection, providing a durable solution and international responsibility-sharing and is one piece within a broader protection regime. ${ }^{2}$ Under the auspices of the Office of the United Nations High Commissioner for Refugees (UNHCR), it has undergone refinement and reinvigoration since the time of the Indochinese movement. This article follows the evolution in both UNHCR and Canadian resettlement selection policy from the time of the Indochinese movement to mid-2015. It highlights key developments and notes how some elements from the Indochinese era are once again relevant.

The resettlement of Indochinese refugees was a defining movement for refugee resettlement, both internationally and for Canada. Almost two million Indochinese were resettled between 1975 and 1997 from countries of first asylum and through orderly departure programs (legal emigration from the source country). ${ }^{3}$ Canada alone resettled over 200,000 Indochinese during this period. ${ }^{4}$ The offers of large-scale resettlement ultimately brought an end to the pushback of Vietnamese boats and ensured those fleeing Vietnam access to asylum. ${ }^{5}$ While the vast majority went to the United States, Canada, Australia, or France, a large number of countries were involved in resettling Indochinese refugees. ${ }^{6}$ Their collective efforts demonstrated the ability of states to work together to resolve a large-scale refugee crisis through resettlement. With the establishment of the Comprehensive Plan of Action (CPA), 7 resettlement became part of a protection framework that included refugee status determination, resettlement of recognized refugees, returns of refused asylum seekers, and an orderly departure program.

The movement also highlighted some of the critiques of resettlement. The availability of resettlement was viewed by 1988 as a "pull factor" involving both refugees and economic migrants. ${ }^{8}$ Although there were other refugees around the world with needs for serious protection and durable solution that could have been resolved through resettlement, this durable solution was virtually reserved for the Indochinese, as it was not until 1993 that Vietnamese made up less than half of all those resettled globally. 9 The reality that those being resettled were fleeing communist states was consistent with the critique that resettlement was effectively a Cold War instrument. ${ }^{10}$ The perceived automatic resettlement of Indochinese asylum-seekers arriving over many years led to a malaise about resettlement inside UNHCR. Many staff began feeling that although this movement enabled access to asylum, UNHCR's work in resettling Indochinese refugees was more akin to that of a travel agency than a protection agency. ${ }^{11}$

For Canada, the Indochinese movement was well timed. A decade earlier Canada had removed race as a factor in immigration selection and had signed the 1951 Refugee Convention and the 1967 Protocol. The implementation of the 1976 Immigration Act introduced a more transparent resettlement framework. It also enabled the creation of designated classes, ${ }^{12}$ giving Canadian officials the ability to apply a lower threshold in selecting members of a designated group for resettlement. In Canada, individuals and groups were so moved by the plight of the Indochinese that they not only advocated for government action, but also organized a public response encouraging Canadians "to rescue" the Indochinese through the private sponsorship program. This movement was facilitated by an interested media and a government who welcomed the opportunity to tap into the public concern of Canadians. ${ }^{13}$ The spirit of volunteerism and the large numbers eventually resettled to Canada were recognized in 1986 when the "People of Canada" were awarded the Nansen Medal, the only time the medal has been awarded to the people of a country.

\section{The Evolution of Resettlement and UNHCR's Increased Leadership Role}

In the decades prior to the Indochinese movement, the international community already had experience working together to offer resettlement as part of the response to a select number of refugee crises, mainly in Europe. As noted, while the Indochinese refugees dominated resettlement internationally for some time, the view of resettlement evolved while this movement was effectively winding down. This was noted in the 1994 evaluation UNHCR undertook to review the implementation of its resettlement policy and practice:

The scale of resettlement activities has changed dramatically over the last decade and a half. In 1979, at the peak of the refugee outflows in South East Asia, resettlement was viewed by most, if not all parties concerned, as the only viable durable solution for approximately 1 in 20 of the world's 5-6 million refugees. In 1993, this ratio had fallen dramatically to just 1 in 40o. Despite a quadrupling of the world's refugee population in the interim, this represents a significant drop in the absolute number of UNHCR cases being resettled, from over 200,000 a year in the late 1970 s to $50-60,000$ a year in the mid-1990s. At the same time, major resettlement countries have focussed their efforts on other refugee and refugee-like caseloads, and not those cases identified by UNHCR. ${ }^{14}$
(C) Author(s), 2016. This open-access work is licensed under a Creative Commons Attribution-NonCommercial 4.0 International license.
Cette oeuvre en libre accès fait l'object d'une licence Creative Commons Attribution-NonCommercial 4.0 International. 
The evaluation underscored the fact that a large part of resettlement taking place globally did not involve UNHCR, and that state selection was not always on the basis of the refugee definition. Where UNHCR was involved, questions were raised about the quality of submissions. ${ }^{15}$

The ideas in the evaluation set the course for resettlement for the next few years. While critical of UNHCR in some aspects, it also affirmed that governments were increasingly looking to UNHCR for direction on resettlement. Among the resulting initiatives was a reaffirmation of UNHCR's leadership on resettlement with the support of resettlement states, including the formal endorsement of the resettlement criteria outlined in the 1996 Resettlement Handbook. The Working Group on Resettlement and the Annual Tripartite Consultations on Resettlement were established as the forums to engage multilaterally on resettlement. Fur thermore, as part of UNHCR's leadership, its headquarters redirected their efforts into policy oversight, training, and tools development.

In 1999 evidence arose concerning widespread malfeasance relating to the refugee status determination and resettlement process in UNHCR's office in Nairobi. ${ }^{16}$ The December 2001 report on the investigation conducted by the UN Office of Internal Oversight Services concluded that there was a largescale criminal network involving UNHCR and non-UNHCR staff who demanded and received money to enable refugees and others to emigrate from Kenya to Australia, Canada, the United Kingdom, and the United States. ${ }^{17}$ The report, which made a number of technical recommendations in order minimize opportunities for malfeasance in the future, helped place a new impetus on resettlement program integrity and combatting malfeasance, including improved management controls and accountability. ${ }^{18}$ This trend continued with the establishment baseline standard operating procedures ${ }^{19}$ and measures to address fraud. ${ }^{20}$

These tightened controls coincided with increased state focus on security screening following the 11 September terrorist attacks, resulting in new barriers and challenges for some refugees to access resettlement. It is difficult to truly quantify the full impact of security restrictions on access to refugee resettlement, since resettlement is a voluntary activity of states, and UNHCR offices may temper their resettlement referrals, on the basis of which states are willing to consider and logistically able to resettle. Overall, it is clear that, following 11 September, security concerns have presented a significant barrier to the resettlement of some refugees. This was most evident in the United States, whose 2001 Patriot Act included provisions barring persons who were defined as providing "material support" to terrorism, resulting in "thousands of refugees in need of urgent protection ... being put on hold for the us Refugee Program due to the expanded definition and over-broad application of the material support bar."21

In Canada, the 2002 Immigration and Refugee Protection Act (IRPA) also included a number of security-related inadmissibility provisions. Section 34-which bars individuals who are "a member of an organization that there are reasonable grounds to believe engages, has engaged or will engage in acts"22 "of subversion against a democratic government, institution or process as they are understood in Canada"23 - was a concern for advocates, since the related screening had resulted in, at the very least, slow processing for some refugees being considered for resettlement. ${ }^{24}$

Security concerns have also meant restrictions on travel for the safety of government officials affected their ability to conduct face-to-face selection of refugees for resettlement, the result being that some refugees cannot benefit from resettlement simply because of where they are located. ${ }^{25}$

The next steps in the evolution of resettlement can be linked to UNHCR's Global Consultations on International Protection, launched in July 2000 to revitalize the international protection regime and commemorate the 5oth Anniversary of the 1951 Refugee Convention. The consultations engaged refugees, governments, IGOs, NGOs, and legal experts on the greatest challenges facing refugee protection at the time. The result was the Agenda for Protection, which was endorsed by the Executive Committee of UNHCR in October 2002. While not legally binding, the Agenda for Protection proposed six goals to guide concrete action. ${ }^{26}$ "Goal 5: Redoubling the search for durable solutions" sought to invigorate all three durable solutions: voluntary repatriation, local integration, and resettlement. One objective was "expansion of resettlement opportunities":

- Make resettlement more available globally in terms of diversifying the composition of the refugees selected for resettlement

- Expand the number of refugees resettled overall

- Increase the number of resettlement countries

- Use resettlement strategically ${ }^{27}$

Strategic use of resettlement was proposed to help unlock solutions for a greater number of refugees beyond those resettled. It was defined as "the planned use of resettlement in a manner that maximizes the benefits, directly or indirectly, other than those received by the refugee being resettled. Those benefits may accrue to other refugees, the hosting State, other States or the international protection regime in general." 28

A key impetus behind this initiative was increased concern about the number of refugees living in protracted refugee situations or what was described as "warehousing refugees."29 The hope was that resettlement might be used in combination with other solutions to provide comprehensive
(C) Author(s), 2016. This open-access work is licensed under a Creative Commons Attribution-NonCommercial 4.0 International license.
Cette oeuvre en libre accès fait l'object d'une licence Creative Commons Attribution-NonCommercial 4.0 International. 
solutions to refugee situations. Canada was an important proponent and facilitated the Convention Plus Core Group on the Strategic Use of Resettlement. In June 2004 the Core Group released the Multilateral Framework of Understandings on Resettlement as a tool to guide parties on situationspecific multilateral agreements to design comprehensive arrangements in resettlement operations.

These developments added to the pressure on UNHCR to expand resettlement activities by increasing the number of resettlement case submissions from a greater number of locations, while also dedicating additional resources to strengthen program integrity. This pressure was particularly pronounced from larger resettlement countries, who require thousands of individual resettlement submissions to meet their resettlement arrivals targets-which the United States increasingly linked to UNHCR submissions. ${ }^{30}$ UNHCR therefore also faced the practical challenge of making enough resettlement submissions for states to meet their resettlement targets. The reality was that UNHCR resettlement submissions were well below the number of spaces made available for resettlement.

In order to address the realities of protracted refugee situations, and to expand the number of resettlement submissions, UNHCR developed a group referral methodology. This approach is meant for situations where there are a sizeable number of refugees with a common refugee claim and a common durable solution need. Rather than completing individual Resettlement Registration Forms (RRF), ${ }^{31}$ UNHCR instead simply submits registration information for the members of the group and a "Group Profile and Proposal," which outlines composition of the group, a durable solution and resettlement needs analysis, challenges and obstacles to group processing, and logistical and resource constraints. Through this simplified methodology thousands of refugees in need of a durable solution can be submitted at a time. The group methodology has been key not only to enable resettlement countries to meet their targets, but also to resettle some protracted refugee populations such as groups of Somalis in Kenya, Myanmar refugees in Thailand, and refugees from Bhutan in Nepal. Through group processing and by seeking out additional funding and staffing, UNHCR was able to increase submissions above the number of places made available by resettlement states.

While increasing its submissions, UNHCR simultaneously changed its approach to more accurately identify resettlement needs. Each UNHCR operation was required to undertake an annual comprehensive assessment of resettlement needs uninfluenced by the availability of resettlement spaces. Following this approach, overall identified resettlement needs increased from 77,824 for $2004^{32}$ to 958,429 for 2015.33
Table 1. UNHCR annual resettlement submission to all countries

\begin{tabular}{lr}
\hline Year & Submissions \\
\hline 2003 & 35,202 \\
2004 & 39,506 \\
2005 & 46,260 \\
2006 & 54,182 \\
2007 & 98,999 \\
2008 & 121,177 \\
2009 & 128,558 \\
2010 & 108,042 \\
2011 & 91,843 \\
2012 & 74,835 \\
2013 & 93,226 \\
2014 & 103,890 \\
\hline
\end{tabular}

Sources: Figures for 2003 and 2004 generated from UNHCR Resettlement Statistical Database Portal, http://www.unhcrwashington.org/rststat. Figures for 2005 to 2014 from UNHCR, UNHCR Refugee Resettlement Trends 2015 (Geneva: UNHCR, 2015), 24.

This revised approach made it clear that global resettlement needs were far more than the number of resettlement places available. Despite an increase in the number of countries participating in resettlement, the number of resettlement spaces made available for UNHCR submissions increased from 50,000 to only 80,000 between 2004 and 2011. ${ }^{34}$ Given the obvious gap between needs and spaces, UNHCR continues to advocate for the availability of more places and for simplification of selection processing, and has kept its submissions linked closer to the number of resettlement spaces, as opposed to resettlement needs.

UNHCR stopped increasing the number of overall submissions in 2010 because resettlement countries were not keeping pace. In fact UNHCR began consciously reducing its resettlement submissions, recognizing that the backlogs created when resettlement departures do not keep pace with submissions would lead to problems of managing expectations and serious frustrations among the refugee population identified for resettlement.

\section{Evolution of Canadian Resettlement since the Indochinese Movement}

While Canadian resettlement already had a long history of involving faith communities and ethno-cultural groups, the 1976 Immigration Act created the private sponsorship program as a new mechanism for individuals to become involved in resettling refugees that was separate from the government-assisted (GAR) program. This mechanism
(C) Author(s), 2016. This open-access work is licensed under a Creative Commons Attribution-NonCommercial 4.0 International license.
Cette oeuvre en libre accès fait l'object d'une licence Creative Commons Attribution-NonCommercial 4.0 International. 
enabled Canadians and permanent residents to come together to sponsor refugees, initially as individual "groups of five." A few months later, to facilitate and promote increased private sponsorship, the government developed and began signing Master Agreements (later renamed Sponsorship Agreements) with incorporated organizations. 35 These organizations, initially mainly faith groups, serve as financial guarantors, enabling the organization and its constituent groups to apply to sponsor a refugee(s) without having to demonstrate the financial capability for each individual application as required of a Group of Five.

When the global Indochinese appeal was launched, the government collaborated with advocates in civil society concerned about the plight of the Indochinese refugees. Together they used the private sponsorship program as the catalyst for Canada's large-scale response to the crisis. Canada effectively used a matching gift model that the government often uses to respond to humanitarian emergencies through which the government commits to match the dollars donated by the public. For the Indochinese, the government offered a one-to-one match of resettlement spaces, committing a national GAR spot for every Indochinese refugee sponsored by a private sponsoring group (regardless of whether by a Group of Five or through a Master Agreement). ${ }^{36}$ The resulting private sponsorship response far exceeded initial government expectations, but the commitments were met, resulting in the largest resettlement of any single group to Canada. While this model established that privately sponsored refugees should be "additional" to government commitments, which became core to the motivation for the private sponsorship program, it also used the private sponsorship program as a key part of Canada's national response to the Indochinese refugee crisis.

The Immigration Act introduced eligibility and admissibility (security, medical, and criminal screening) requirements for resettlement. The creation of the Indochinese Designated Class in the regulations helped make it easier for Canadian officials to find Indochinese refugees eligible for resettlement to Canada. The definition of the Indochinese Designated Class was

a class of persons the members of which (a) are citizens or habitual residents of a country listed in the schedule, (b) have left their country of citizenship or former habitual residence subsequent to April 30, 1975, (c) have not become permanently resettled, (d) are unwilling or unable to return to their country of citizenship or former habitual residence, (e) cannot avail themselves of the protection of any other country, and (f) are outside Canada and seeking resettlement in Canada. ${ }^{37}$
This test of having simply left their country and being unwilling or unable to return to Vietnam and having no other solution was much less stringent than determining whether the individual met the Convention Refugee definition. This made the eligibility assessment of Indochinese refugees much easier for Canadian officials and greatly increased the likelihood of acceptance. As the Canadian criteria effectively matched the prima facie status given to Vietnamese refugees up until the time of the CPA, submissions to Canada were simplified, and the risk of large numbers being refused resettlement admission was minimized. Statistics from the time show heavy reliance on the designated class for selection of Indochinese refugees. From 1978 until 1994, 136,951 Indochinese were resettled, of which 129,105 were selected under the Indochinese Designated Class and only 7,846 as Convention Refugees. ${ }^{38}$ In fact it was not until 1992 when the CPA (which required as a precondition for resettlement that the person be found to be a Convention Refugee) was well in place, that the number of Vietnamese selected as Convention Refugees exceeded the number selected under the Indochinese Designated Class. ${ }^{39}$ Reliance on the designated classes to meet Canadian resettlement targets was part of a larger trend. The majority of persons resettled to Canada came under the designated classes for every year between 1979 and 1992.40 The end of this trend may also reflect the fact that by the end of this period, the Cold War was over ${ }^{41}$ and the CPA was well established.

The political changes occurring with the end of the Cold War necessitated a review of Canada's designated classes, and by 1994 proposals were developed as a result of national immigration consultations. As the Immigration Act of 1976 brought transparency and introduced independent criteria for the selection of who was to be resettled as a Convention Refugee, the changes to the designated classes established transparent independent criteria for selecting persons who may not meet the refugee definition but were in "refugeelike" situations, ${ }^{42}$ in place of requiring the political approval to create or dissolve each individual designated class. The required regulatory changes came in 1997, replacing the previous designated classes with the Country of Asylum Class and the Source Country Class under the Humanitarian Designated Classes Regulations. Selection under the Country of Asylum Class required, among other things, that an applicant "has been and continues to be serious and personally affected by civil or armed conflict or a massive violation of human rights in the immigrant's country of citizenship or of habitual residence." 43 The definition was also limited to persons who were privately sponsored or had the financial ability to be self-supporting upon arrival in Canada.
(C) Author(s), 2016. This open-access work is licensed under a Creative Commons Attribution-NonCommercial 4.0 International license.
Cette oeuvre en libre accès fait l'object d'une licence Creative Commons Attribution-NonCommercial 4.0 International. 
Although regulatory changes were implemented in 1997, pressures to further revamp Canadian resettlement continued until 2002, when the IRPA came into effect. The most prominent was the Immigration and Legislative Review, whose report recommended revamping the protection framework in Canada. Among its recommendations was that resettlement should prioritize those "most vulnerable and those most in need." Furthermore it stated, "There should be no requirement that applicants be likely to establish themselves successfully in Canada." 44 While the government did not adopt the bolder recommendations from the report, including that Canada should establish a single protection system with a single protection agency covering overseas and in Canada, the government did commit to "a more responsive resettlement program"45 by

- Shifting the balance toward protection rather than the ability to settle successfully in selecting refugees;

- Establishing procedures that will allow members of an extended refugee family to be processed together overseas and, where this is not possible, providing a mechanism for the speedy reunion of families;

- Working more closely with non-governmental organizations in identifying, pre-screening and resettling refugees; and

- Ensuring the immediate entry into Canada of urgent protection cases. ${ }^{46}$

During this period leading up to the new Act, a number of forums/consultations on resettlement influenced the development of IRPA and the resulting regulations, and were part of a slow series of incremental shifts to Canadian resettlement. 47

One example was the International Symposium on the Resettlement of Women at Risk hosted by Citizenship and Immigration Canada (CIC) and UNHCR in Toronto in 1998. Among the recommendations was that "resettlement countries should expedite processing of emergency cases in order to reduce protection risks." 48 This initiative, along with the existing impetus from the legislative review, was the foundation for the Urgent Protection Program Pilot launched in 2000.

The Immigration and Refugee Protection Regulations introduced significant changes into Canada's resettlement framework, changes that reflected the shift towards protection. The three categories remained-Convention Refugees Abroad Class, Country of Asylum Class, and Source Country Class-with the last two classes renamed the Humanitarian-Protected Persons Abroad classes. To facilitate family reunification, a "one year window" program was created, enabling dependent family members of resettled refugees in Canada to be resettled under the same program if they submitted an application at a Canadian mission within one year of their family member's arrival in Canada.
A key change was the removal of direct access to a Canadian mission to request resettlement, placing increased importance on UNHCR's resettlement submissions. The regulations introduced a requirement that a person being resettled be "referred" to Canada. 49 Thus, in order to be resettled a person had to be referred by:

- UNHCR

- Another (designated) "Referral Organization"

- A private sponsor (i.e., already has a private sponsorship)

- A foreign state with which Canada has an agreement.50

While the ability to successfully establish remained in Canada's regulations as a requirement for resettlement, the regulations introduced two exemptions to respond to refugees whose protection needs effectively trumped this concern. The exemptions are for refugees determined by a foreign service officer to be in "urgent need of protection" or "vulnerable."

"Urgent need of protection" means, in respect of a member of the Convention refugee abroad, the country of asylum or the source country class, that their life, liberty or physical safety is under immediate threat and, if not protected, the person is likely to be

(a) killed

(b) subjected to violence, torture, sexual assault or arbitrary imprisonment, or

(c) returned to their country of nationality or of their former habitual residence. ${ }^{51}$

"Vulnerable" means, in respect of a Convention refugee or a person in similar circumstances, that the person has a greater need of protection than other applicants for protection abroad because of the person's particular circumstances that give rise to a heightened risk to their physical safety. ${ }^{52}$

These definitions gave Canadian officers the means to surmount the ability to establish requirement ${ }^{53}$ for refugees with desperate protection needs. It also reflected a trend to be more lenient when applying the ability to establish requirement. This view can be seen in the operational manuals of the time, which urged visa officers to apply ability to successfully establish with a three- to five-year timeframe in mind, ${ }^{54}$ so there was already a focus on leniency in applying this requirement. Officers were therefore given tools to better respond to UNHCR referrals, reducing the prospect of refusals of applicants on non-protection related grounds. Since UNHCR's resettlement criteria are guided by protection and/or durable solution need, there is no consideration of the applicant's ability to establish in a resettlement country as a condition for a resettlement referral.55 If Canada applied the ability to establish criterion stringently, it could undermine the protection function of the program by moving
(C) Author(s), 2016. This open-access work is licensed under a Creative Commons Attribution-NonCommercial 4.0 International license.
Cette oeuvre en libre accès fait l'object d'une licence Creative Commons Attribution-NonCommercial 4.0 International. 
the focus away from those who need resettlement most. In addition, at an operational level, high numbers of refusals means a waste of resources for both UNHCR and Canada. A similar important development in selecting refugees on the basis of their protection needs was removal of the excessive medical demand as a barrier for the selection of refugees for resettlement.

The regulatory change also facilitated creation of the Urgent Protection Program (UPP). While not in the regulations, Canada's overseas processing manual explains that Canadian missions or visa posts should ensure that UPP cases receive immediate attention. ${ }^{56}$ Canada has set out processing benchmarks for missions, advising that upon receiving an emergency submission from UNHCR, the receiving Canadian mission should inform UNHCR within 24 hours whether or not it can process the application under the UPP. If it confirms that it can do so, it should try to complete the applicant's processing (including departure) within five days. Although Canadian missions have seldom met these timelines, the UPP established a structure for Canada to process UNHCR emergency submissions, including expedited security reviews in Ottawa, in order to facilitate the processing. From 2010 to 2013, 87 emergency cases arrived in Canada. 57

One development established outside the regulations was a means for Canada to undertake group processing of refugees for resettlement. This model was developed specifically to respond to "the very practical operational difficulties facing Canada in terms of securing sufficient referrals from UNHCR and matching limited resources and resettlement spaces to those refugees most in need of Canada's protection through resettlement." 58

Given its concern about ensuring sufficient referrals, Canada began testing group processing as a selection model. In 2003 UNHCR provided detailed profiles of two populations in the Dadaab refugee camps-a group of Sudanese Christians and Somalis from the Madhiban clan in Kenyafor a group processing pilot. For CIC to facilitate processing of the group, they established two key components: "first, that the members of the identified group were prima facie Convention refugees; and second, that the prima facie refugees were deemed 'vulnerable' and therefore, according to our Regulations did not need to meet the ability to establish criteria." 59

While this group referral project was organized in cooperation with Australia, the subsequent group-processing referrals were organized with a much larger group of resettlement states. The identification of the group for the pilot in Kenya involved UNHCR consulting locally with the Canadian High Commission in Nairobi before making the referral. While Canada was undertaking this pilot, UNHCR developed its procedure and forms for making a group referral under the group methodology referred to earlier. This format became the basis for a number of group referrals to Canada made over several years, including Myanmar refugees from the Thai border camps of Mae La Oon and Mae Ra Ma Luang and, subsequently, refugees from Bhutan in Nepal.

The efficiency of group processing for Canada was apparent. Once Canadian officials effectively accepted the UNHCR referral at headquarters, the missions reviewing the related registration documents undertook preparatory work, enabling teams of Canadian officials to visit the camps and select hundreds of refugees for resettlement within a few days. Working from the premise that the refugees referred were eligible for resettlement, interviews focused only on verification of the refugees' identity and membership in the group and admissibility to Canada. In 2011 group processing of Bhutanese refugees made up 20 per cent of those resettled to Canada under the GAR. ${ }^{60}$

Canada also used simplified processing for select refugee populations. A few years after IRPA's passage, Canada resettled a large number of Afghan refugees from a number of countries in Central Asia through a simplified submission process that effectively involved UNHCR forgoing preparing an individual RRF but instead sharing registration information and completing a Canadian permanent resident application for each Afghan refugee.

UNHCR's guidelines on the protection needs of select refugee populations also helped Canada formulate guidance for Canadian missions on the eligibility of select refugee populations, which became the basis for high acceptance rates. For example, Canada's resettlement of large numbers of Iraqis in the years following UNHCR's Iraqi resettlement appeal on 14 February 2007 was emboldened by UNHCR's December 2006 guidelines on Iraqi protection needs, which included recommendations that "Iraqi asylum-seekers from Southern and Central Iraq should be favourably considered as refugees under the 1951 Convention relating to the Status of Refugees." 11 International protection guidance has since allowed Canadian officers to "concentrate on the review of GAR on the basis of admissibility (i.e. does the GAR pose a security or health risk) rather than on the basis of eligibility (is the GAR an eligible refugee under Convention definitions),"62 also resulting in higher acceptance rates.

Canada's efforts to adjust its resettlement program through policy and operational measures made it more coherent with UNHCR identified resettlement needs. The positive result is that Canada's acceptance rate of UNHCR referrals is generally around 90 per cent. ${ }^{63}$ However, UNHCR emergency referrals do not fare as well, ranging from 55.8 to 70 per cent from 2010 to 2012,64 although this percentage is consistent with a lower
(C) Author(s), 2016. This open-access work is licensed under a Creative Commons Attribution-NonCommercial 4.0 International license.
Cette oeuvre en libre accès fait l'object d'une licence Creative Commons Attribution-NonCommercial 4.0 International. 
global acceptance rate for emergency cases among overall submissions to all resettlement countries. ${ }^{65}$

The government introduced a new round of resettlement changes in 2010, while overhauling its immigration programs. In March 2010, Canada pledged to expand resettlement by 20 per cent by creating an additional 2,000 private sponsorship spaces and 500 GAR spaces (along with a 20 per cent increase in Resettlement Assistance Program funding) upon passage of the government's reforms to the asylum system. ${ }^{66}$ There were subsequent regulatory and policy changes. One was the elimination of the Source Country Class, which CIC argued was "inefficient, [and] unresponsive to evolving protection needs" and that its removal would allow for more referral spaces for UNHCR's resettlement needs at a time when UNHCR was appealing for more spaces. ${ }^{67}$ Nevertheless, despite the 2010 pledge to expand resettlement, the 2012 budget overtook this commitment, and instead led to the creation of the Blended Visa Officer Referred (BVOR) program, a hybrid program matching UNHCR identified cases to private sponsoring groups, and dividing responsibility for the financial support between the government and the sponsors. This enabled the government to reduce the GAR program without reducing the potential number of UNHCR referral spots at a time when UNHCR was appealing for additional resettlement spaces to respond to the global resettlement need.

At the same time the government began responding to concerns from service providers that the changes resulting from IRPA (elimination of the excessive medical demand and the focus away from ability to establish) was resulting in increased demands on settlement services. ${ }^{68}$ CIC proposed to refocus Canada's GAR resettlement program upon a few populations through multi-year commitments, which would ideally assist service providers in their integration program planning while also trying to limit the number of "high medical needs" 69 cases referred by UNHCR. The goal was to move Canadian resettlement selection from a global resettlement program with a few multi-year commitments that were focused primarily on protection needs built around two programs (GAR and PSR). In its place the government proposed three program streams (GAR, PSR, and BVOR) with "targeted, multi-year commitments" and a "focus on protection need and settlement capacity."70

2015 multi-year resettlement commitments include:

- 4,00o Iraqis out of the Middle East by 2015 , towards an overall commitment of 20,00o Iraqis, along with an additional commitment of 3,000 Iraqis in 2015;

- 1,000 Bhutanese out of Nepal in 2015, towards an overall commitment of 6,500 Bhutanese;

- 5,000 refugees out of Turkey between 2013 and 2018 (Iraqis and Iranians in the short term);
- 10,00o Syrians from the region in 2015-17;

- 900 Colombians out of Ecuador between 2014 and 2017;

- 4,00o Eritreans out of Eastern Sudan and Ethiopia between 2014 and 2019; and

- 2,500 Congolese out of Tanzania and Burundi between 2015 and $2018 .^{71}$

Another important aspect of the multi-year commitments was the engagement of the political level in determining where Canada would commit. ${ }^{72}$ While all of Canada's commitments made are linked to UNHCR identified needs, Canada has not responded to every resettlement need identified by UNHCR.

While the makeup and number of resettled refugees has been redistributed among programs, the one area of growth in resettlement has been outside the refugee stream through the development of "public policy" spaces. While the numbers selected through this mechanism are not entirely clear, ${ }^{73}$ the target for 2015 was $900-1,200$ persons. Public policy spaces are created under the power of the minister to grant "permanent resident status or an exemption from any applicable criteria or obligations of this Act if the foreign national complies with any conditions imposed by the Minister and the Minister is of the opinion that it is justified by public policy considerations." 74 This tool has been used for persons from a variety of populations including Afghan interpreters who worked with Canadian forces, Tibetans residing in Arunachal Pradesh, and a group of Haitian victims of violence referred by UNHCR from inside Haiti. Also included under public policy have been "stateless" Vietnamese from Southeast Asia, some of whom apparently date back to the time of the CPA, and/or including persons who have married nationals in other countries in Southeast Asia.

\section{The Private Sponsorship Program Evolution}

As noted at the outset, the private sponsorship program helped facilitate Canada's tremendous response to the Indochinese movement. The Private Sponsorship Program, like resettlement policy overall, has undergone its own evolution since the Indochinese movement. While the timing of the program's creation was fortuitous, also key to the overwhelming response was the political will and the determination of advocates to engage not only the government but ordinary Canadians in order to organize and form sponsorship groups. While the movement was effectively implementing government policy, it also established "additionality" as a component of the private sponsorship program. Every Indochinese refugee sponsored by a private group ultimately resulted in an additional refugee resettled to Canada by the government as a result of the matching formula the government put in place.
(C) Author(s), 2016. This open-access work is licensed under a Creative Commons Attribution-NonCommercial 4.0 International license.
Cette oeuvre en libre accès fait l'object d'une licence Creative Commons Attribution-NonCommercial 4.0 International. 
Following the high of approximately 35,000 refugees privately sponsored in $1979-80,75$ the program hovered around $3,800-5,800$ privately sponsored refugees admitted each year until $1987,7^{76}$ and experienced another surge in the late 1980s. This surge reflected the resettlement of large numbers under the East European Self-Exiled Designated Class, particularly individuals from Poland who were sponsored by Polish ethnic groups and faith communities in Canada. This was part of a general trend of fewer private sponsorship cases being identified by visa officers, with sponsors instead responding directly to requests for resettlement from persons overseas who were either identified by family or friends in Canada or from partner organization overseas. By the end of the 1980s both the government and NGOS recognized strains on the private sponsorship program. "The dramatic increase in numbers (from 7,621 in 1987 to 21,212 in 1989) challenged the government's planning and management systems. The program that began as an imaginative and flexible partnership between the private sector and the government was, by 1990, beginning to experience mistrust on both sides." 77

In 1990 the government undertook a comprehensive review of the PSR program..$^{8}$ While there were a subsequent number of reports, recommendations, and new forums for consultation during the 1990s, this period also demonstrated the program's flexibility to respond to time-limited special initiatives. These include Project Focus Afghanistan implemented with the Ismaili community between 1994 and 1998, the Special 3/9 Sponsorship Pilot Program in response to a UNHCR appeal for resettlement of refugees from the former Yugoslavia, and the Sierra Leone Blended Sponsorship Pilot-with the government providing the sponsored refugees four months' financial assistance and the sponsors providing the remaining eight months'. However, the most significant initiative was the sponsorship of 5,000 evacuated refugees from Kosovo in 1999. The media attention and outpouring of willingness to assist Kosovar refugees was the largest public involvement in resettlement since the time of the Indochinese. All of these special initiatives in the 1990s involved slight adjustments to the private sponsorship program, which spoke to its agility and the willingness of the volunteers involved to respond to new needs and realities.

The following decade saw technical changes in the processing of sponsorship submissions, but the same issues that had plagued the private sponsorship program, including slow processing and backlogs, continued to concern sponsors.

CIC began proposing in 2006 that sponsors voluntarily control the number of applications submitted at missions, so that missions could clear out their backlogs, since the number of sponsorship applications in the system far exceeded mission targets. 79 However, in 2011 the government imposed caps on private sponsorships at the Canadian High Commission in Nairobi, where the mission backlogs were most acute, and in 2012 the government enforced limitations by placing caps on overall submissions by Sponsorship Agreement Holders. The government also implemented regulatory changes in 2012 restricting groups of five to sponsoring only recognized refugees, ${ }^{80}$ thus effectively limiting their submission levels. Despite efforts to control backlogs and processing delays, this problem continued, part of which was associated with the initial establishment of a central processing office for private sponsorship applications.

The private sponsorship program received increased political attention after the 2006 election. While the government worked to control the number of new applications, the refugee reform package led to increased annual targets for the private sponsorship program. At the same time, the private sponsorship program was increasingly included as part of the government's overall response to refugee needs. While private sponsors on their own initiative were involved in sponsoring Palestinians ex-Iraq ${ }^{81}$ in response to UNHCR's appeal, private sponsorships were Canada's response to UNHCR's resettlement appeal for the refugee population displaced by the "Arab Spring" in Libya who fled to Tunisia. Canada's multi-year resettlement commitments incorporate private sponsorship admissions. For example, Canada's pledge to resettle 1,300 Syrian refugees in 2013-14 committed private sponsors to resettle 1,100 of this total, with the national GAR program allocating spaces for only 200 Syrians ${ }^{82}$ Private sponsorships were also a part of Canada's January 2015 pledge to resettle 10,000 Syrian refugees between 2015 and 2017. In addition, the BVOR program was founded on the expectation that private sponsors take on part of the cost of resettling refugees referred by UNHCR.

\section{Legacy of the Indochinese Movement and Today's Challenges}

Since the time of the Indochinese movement, resettlement has become much more complex and resource-intensive, and has also gained international legitimacy as it has become more responsive to global protection needs. The number of countries committed to regularly resettling refugees referred by UNHCR continues to grow. Despite the fact that only a small percentage of refugees are resettled each year, resettlement has been given greater importance as a legal migration pathway in response to some of the greatest challenges facing the international protection regime. The most recent example, at the time of writing, is UNHCR's goal of resettling 10 per cent of the Syrian refugee population. ${ }^{83}$

Canada has remained a key resettlement player over successive governments. The changes introduced with the
(C) Author(s), 2016. This open-access work is licensed under a Creative Commons Attribution-NonCommercial 4.0 International license.
Cette oeuvre en libre accès fait l'object d'une licence Creative Commons Attribution-NonCommercial 4.0 International. 
adoption of IRPA in 2002 recognized the humanitarian nature of refugee resettlement, diminishing the need for refugees to demonstrate that they could "establish" themselves, and no longer excluding refugees on the basis of "excessive medical demands.” In effect, Canada's post-IRPA selection strategies mirrored UNHCR initiatives to respond more effectively to identified resettlement needs. However, while selection barriers diminished, this period saw the beginning of increased attention to security admissibility requirements.

Yet the removal of barriers that represented a more "open door" policy for high-needs cases following IRPA led to internal concerns about managing the number of resettlement cases with high medical or other settlement needs.

One key to the Indochinese movement's operational success was the simplicity of eligibility assessments and processing. In recognition of the global value of this durable solution, there is a current push to regain some of this simplicity. UNHCR continues to engage with states to simplify resettlement submissions, given the amount of work that can go into documenting a single submission. ${ }^{84}$ Greater simplicity is required if this solution is to be expanded significantly.

Although the surge of public interest in assisting refugees in the latter half of 2015 raised the profile of private sponsorship once again, the private sponsorship program has continued to engage Canadians in the resettlement of refugees since the Indochinese movement. Through it, hundreds of thousands of refugees have been resettled to Canada. The Conservative government made changes to bring the program into greater coherence with the government's overall direction on resettlement. It more directly linked the program to Canada's choice of priority populations and responses to current resettlement needs, similar to the Indochinese era. However, these adjustments, along with efforts to manage the backlogs that have crippled the private sponsorship program, also partially compromised the additionality value that the program brought to Canada's collective resettlement effort.

Even prior to the 2015 federal election campaign, resettlement had become more visible in political debates, and the political level of government appears more engaged in resettlement's direction and management. It is recognized that involvement of the political leadership during the Indochinese movement enabled the creation of the Indochinese Designated Class and, more importantly, sped approval to increase Indochinese arrivals. Canada's move away from relying on designated classes to select refugees for resettlement in the 1990s was nevertheless welcome, since this approach, along with the changes surrounding IRPA, made Canada's resettlement programs more responsive to needy refugees around the world instead of focused on select populations.
However, starting in the years of the Conservative government, Canada's focus on multi-year commitments to select populations allows the political level to play an increased role in the decisions on who should be resettled, as it decides which UNHCR identified needs to prioritize. The former government also created a public policy component to Canada's overall humanitarian program, a new area in resettlement through which the political level is able to offer resettlement to a population that does not meet the refugee definition.

Lessons from the Indochinese experience remain relevant to this day. It is a foundation for contemporary resettlement and offered a dramatic demonstration that the public can be a driving force for refugees. This article has sought to provide an overview of the evolution of UNHCR's and Canada's resettlement policies between 1978 and mid-2015 so as to recognize the key changes and interplay between the two. This is not to suggest that there are no other influences in broader debates about refugee protection, migration, and Canada's response recognizing the changing global environment.

Resettlement, by its voluntary nature, reflects elements of diplomacy, strategy, coordination, and cooperation. This extends beyond UNHCR and includes all resettlement countries. Much of this interrelationship remains unknown outside of this circle. Also unknown for those outside government is how much security considerations affect resettlement operations in eligible and operational locations.

This article effectively ends at the beginning of a new chapter in Canadian resettlement. Interestingly the Indochinese movement of the late 1970s appears to be the closest parallel to the resettlement of Syrians taking place in 2015 and 2016. It is not yet clear what the "new normal" will be for Canada's resettlement program, recognizing that Canada's 2016 resettlement admission target of 44,800 persons ${ }^{85}$ is the largest since the Immigration Act of 1976, and the government has not indicated its resettlement admission plans at the time of writing for 2017 and beyond. While much has changed, there are key parallels and contrasts between the Indochinese and Syrian resettlement movements in a variety of areas, including scale, political leadership, public opinion, public engagement, and overseas and domestic operational practices, which will no doubt be the subjects of future examination. The reality that the private sponsorship program, as a model, is the subject of increased interest ${ }^{86}$ shows that the lessons of the Canadian resettlement experience are not simply important for Canada but for other countries as well.

\section{Notes}

1 Ninette Kelley and Michael Trebilcock, The Making of the Mosaic: A History of Canadian Immigration Policy (Toronto: University of Toronto Press, 2000), 390.
(C) Author(s), 2016. This open-access work is licensed under a Creative Commons Attribution-NonCommercial 4.0 International license.
Cette oeuvre en libre accès fait l'object d'une licence Creative Commons Attribution-NonCommercial 4.0 International. 
2 United Nations High Commissioner for Refugees (hereafter UNHCR), UNHCR Resettlement Handbook, rev. ed. (Geneva: UNHCR, 2011), 3.

3 Courtland Robinson, Terms of Refuge: The Indochinese Exodus and the International Response (New York: Zed Books, 1999), app. 2, 295.

4 Ibid.

5 Courtland Robinson, "The Comprehensive Plan of Action for Indochinese Refugees, 1989-1997: Sharing the Burden and Passing the Buck," Journal of Refugee Studies 17, no. 3 (2004): 320 .

6 Robinson, Terms of Refuge, 127.

7 For an analysis of the CPA, see ibid., 187-226.

8 Gil Loescher and James Milner, "Protracted Refugee Situations: Domestic and International Security Implications," Adelphi Paper no. 375 (Basingstoke, uk: Routledge for the International Institute for Strategic Studies, 2005), 72.

9 John Fredriksson and Christine Mougne, "Resettlement in the 1990's: A Review of Policy and Practice" (Geneva: UNHCR, 1994), 6, http://www.unhcr.org/3ae6bcfd4.html.

10 Thais Bessa, "From Political Instrument to Protection Tool: Resettlement of Refugees and North-South Relations," Refuge 26, no. 1 (2009): 94.

11 Fredriksson and Mougne, "Resettlement in the 1990's," 7.

12 Raphael Girard, "Designated Classes: A Regulatory Device to Target Humanitarian Resettlement Programs," Canadian Immigration Historical Society, 1 January 2005, http://cihs-shic.ca/2005/o1/designated-classes/.

13 Howard Adelman and Naomi Alboim, "Draft: A Proposed Revised Refugee Resettlement Policy for a New Age" (2014), 3-5.

14 Fredriksson and Mougne, "Resettlement in the 199o's," 5.

15 Ibid., 8.

16 UNHCR, Office of Internal Oversight Services (OIOs), Investigation into Allegations of Refugee Smuggling at the Nairobi Branch Office of the Office of the United Nations High Commissioner for Refugees (Geneva: oIOs, 2001).

17 Ibid., 1.

18 UNHCR, Global Consultations on International Protection, "Strengthening and Expanding Resettlement Today: Dilemmas, Challenges and Opportunities" (Geneva: UNHCR, 2002), 5 .

19 UNHCR, Annual Tripartite Consultations on Resettlement, "Agenda Item $3 \mathrm{f}$ Information Note: Baseline Standard Operating Procedures on Resettlement" (Geneva: UNHCR, 2007), http://www.refworld.org/docid/46822cffd.html.

20 UNHCR, UNHCR Resettlement Anti-Fraud Plan of Action (Geneva: UNHCR, 2004).

21 Refugee Council usA, The Impact of the Material Support Bar: us Refugee Admissions Program for Fiscal Year 2006 and 2007; Recommendations of Refugee Council USA (Washington: Refugee Council USA, 2006), 7, http://www. rcusa.org/uploads/pdfs/RCUSA20o6finpostbl-w.pdf.
22 Immigration and Refugee Protection Regulations, SOR/2002-227, 34(1)(f), http://laws-lois.justice.gc.ca/eng/ regulations/sor-2002-227/page-1.html.

23 Ibid., 34(1)(a).

24 Canadian Council for Refugees, Eritrean Canadian Community Centre of Metropolitan Toronto, HidmonaEritrean Human Rights Group in Manitoba, Holy Trinity Eritrean Orthodox Church in Toronto, Meftih Eritrea Community Newspaper, Qalna Eritrean Human Rights Group-Toronto, From Liberation to Limbo: A Report on the Impact of Immigration Security Inadmissibility Provision on the Eritrean Community in Canada, and Recommendations for Reform, Submitted to the Ministers of Citizenship and Immigration and Public Safety (Montreal: Canadian Council for Refugees, April 2010), 11.

25 David Kenner, "If You're a Refugee Dreaming of Coming to America, Don't Come to Lebanon," FP Dispatch, 8 December 2015, http://foreignpolicy.com/2015/12/o8/ if-youre-a-refugee-dreaming-of-america-dont-come-tolebanon/.

26 The six Agenda for Protection goals are to (1) strengthen implementation of the 1951 Convention and 1967 Protocol; (2) protect refugees within broader migration movements; (3) share burdens and responsibility more equitably and build capacities to receive and protect refugees; (4) address security-related concerns more effectively; (5) redouble the search for durable solutions; and (6) meet the protection needs of refugee women and refugee children.

27 UNHCR, "Agenda for Protection," A/AC.96/965/Add.1 (Geneva: UNHCR, 2002), http://www.unhcr.org/3d3e61b84.html.

28 UNHCR, "The Strategic Use of Resettlement: A Discussion Paper Prepared by the Working Group on Resettlement," EC/53/sc/CRP.10/Add.1 (Geneva: UNHCR, 2003).

29 For an examination of "warehousing" refugees, see Merrill Smith, "Warehousing Refugees: A Denial of Rights, a Waste of Humanity," World Refugee Survey 2004 (Arlington, va: us Committee for Refugees, 2004), http://refugees. org/wp-content/uploads/2015/12/Warehousing-RefugeesCampaign-Materials.pdf.

30 us Department of State, us Department of Justice, us Department of Health and Human Services, Report to the Congress on Proposed Refugee Admissions for Fiscal Year 1995 (Washington: Government of the United States, 1994), 19. This increase can be seen in UNHCR resettlement submission statistics. In 2003, 20,378 persons were referred, while in 2015 54,218 were referred. (The highest number of referrals in that period was in 2009 with 102, 586). Statistics generated from UNHCR Resettlement Statistical Database Portal, http://www.unhcrwashington.org/rststat.

31 The Resettlement Registration Form is the format by which UNHCR submits individual resettlement cases.

32 UNHCR, UNHCR Projected Global Resettlement Needs (Geneva: UNHCR, 2014), 2.
(C) Author(s), 2016. This open-access work is licensed under a Creative Commons Attribution-NonCommercial 4.0 International license.
Cette oeuvre en libre accès fait l'object d'une licence Creative Commons Attribution-NonCommercial 4.0 International. 
33 UNHCR, UNHCR Projected Global Resettlement Needs, 2015 (Geneva: UNHCR, 2014), 9.

34 UNHCR, 2012 Annual Tripartite Consultations on Resettlement, "UNHCR Discussion Note: The Effective Use of Resettlement Places: Trends and Concerns Related to the Capacity of the Global Resettlement Program" (Geneva: UNHCR, 2012), 1.

35 Barbara Treviranus and Michael Casasola, "Canada's Private Sponsorship of Refugees Program: A Practitioner's Perspective of Its Past and Future," Journal of International Migration and Integration 4, no. 2 (2003): 184.

36 Ibid.

37 Office Consolidation, "Indochinese Designated Class Regulations," http://cihs-shic.ca/wp-content/uploads/ 2015/03/Indochinese-Designated-Class-Regulations-2.pdf.

38 Canada selected an additional 7,708 Indochinese refugees between 1975 and 1978, who arrived under the previous Act when there was no Convention Refugee or Designated Class designation. CIC, International Refugee and Migration Policy Branch, March 1995.

39 Ibid.

40 Canadian Council for Refugees, "Resettlement 1979-1996: Statistical Information" (November 1996), http://ccrweb. $\mathrm{ca} /$ sites/ccrweb.ca/files/static-files/statia.htm.

41 Canada also had a Self-Exiled Designated Class focusing on Eastern Europeans, and a Latin American Political Prisoners and Oppressed Persons Designated Class that was renamed the Political Prisoners and Oppressed Persons Class in 1982.

42 CIC, "Operations Memorandum Refugee and Humanitarian Resettlement Program: In Canada" (Ottawa: Government of Canada), 7.

43 "Humanitarian Designated Classes Regulations," Canada Gazette 131, no. 9 (30 April 1997).

44 See recommendation 88 of CIC, Not Just Numbers: A Canadian Framework for Future Immigration, Immigration Legislative Review (Ottawa: CIC, 1997), 87.

45 CIC, Building on a Strong Foundation for the 21st Century: New Directions for Immigration and Refugee Policy and Legislation (Ottawa: CIC, 1998), 43.

46 Ibid.

47 Michael Casasola, "Current Trends and New Challenges for Canada's Resettlement Program," Refuge 19, no. 4 (2001): 76.

48 CIC and UNHCR Workshop Meeting New Challenges: Evolving Approaches to the Protection of Women at Risk, Summary of Discussions and Recommendations (Ottawa: CIC and UNHCR, 1998), 4.

49 Immigration and Refugee Protection Regulations, SOR/2002-227, s. 140.3 (1).

50 Ibid.

51 Ibid., s. 138.

52 Ibid.

53 Ibid., s. 138(1)(g).
54 CIC, OP 5 Overseas Selection and Processing of Convention Refugees Abroad Class and Members of the HumanitarianProtected Persons Abroad Classes (cic: Ottawa, 2009), 66.

55 UNHCR, Resettlement Handbook, rev., 245.

56 Ibid., 29.

57 UNHCR, "UNHCR Emergency Submissions to Canada 20102014," PowerPoint presentation, Gatineau, CCR Fall Consultation 2014, http://ccrweb.ca/en/system/files/unhcremergency-submissions-to-canada-2010-2014.pdf.

58 cIC, Resettlement Division, Refugees Branch, Group Processing Project Evaluation Final Report (Ottawa: CIC, 2005), 3 .

59 Ibid., 4.

60 CIC, Evaluation Division, Evaluation of Government Assisted Refugees (GAR) and Resettlement Assistance Program (RAP) (Ottawa: CIC, 2011), xii.

61 UNHCR, "UNHCR Return Advisory and Position on International Protection Needs of Iraqis outside of Iraq" (Geneva: UNHCR, 2006), 3, http://www.refworld.org/pdfid/46371aa72 .pdf.

62 CIC, Evaluation Division, Evaluation of GAR and RAP, 13.

63 UNHCR Canada, "Emergency Submissions to Canada 2010-2012: Observations and Trends Analysis," 2013 Annual Tripartite Consultations on Resettlement (Ottawa: UNHCR, 2013), 6 .

64 Ibid.

65 In 2012 UNHCR normal submissions averaged an acceptance rate of 88.8 per cent and emergency submissions averaged a 74.4 per cent. UNHCR, UNHCR Global Resettlement Statistical Report 2012 (Geneva: UNHCR, 2012), 12.

66 CIC, Backgrounder: More Support for Resettled Refugees (Ottawa: CIC, 2012).

67 CIC, Repeal of the Source Country Class of Humanitarian-Protected Persons Abroad, Operational Bulletin 346 (Ottawa: CIC, 7 October 2011).

68 CIC, Evaluation Division, Evaluation of GAR and RAP, 28.

69 CIC presentation, "Refugee Resettlement: Future Directions," Fall 2012, slide 6.

70 Ibid., slide 5.

71 This is compiled from the Refugee Sponsorship Training Program, "Multiyear Refugee Resettlement Commitments," http://www.rstp.ca/en/refugee-sponsorship/ latest-policy-program-update/multiyear-refugee-resettlement-commitments/; and Global Affairs Canada, "Helping to Protect the World's Most Vulnerable," news release, 7 January 2015, http://news.gc.ca/web/article-en do?nid=918349\&_ga=1.28590335.250123850.1460758429.

Canada had a previous commitment of 1,100 Syrian refugees (200 GAR and 1,100 PSR) in 2013 and 2014.

72 CIC, memorandum to the minister, "Follow-up to Portfolio Briefing on Improving Government Assisted Refugee Outcomes," 12 October 2012; CIC, memorandum to the minister, "Resettled Refugee Populations: Multi-Year Commitments for 2013 and Beyond," 30 October 2012; CIC, memorandum to the minister, "Options for Managing 
Resettled Refugees with High Needs," 11 December 2012; and CIC, "Annex C: Resettled Refugee Populations: MultiYear Commitments for 2013 and Beyond."

73 2013-15 Public Policy spaces are noted in Immigration Levels Plans. For 2012 they are combined with Humanitarian and Compassionate Grounds targets. See CIC, "Notice: Supplementary Information for the 2013 Immigration Levels Plan" (Ottawa: CIC, 5 November 2012), http:// www.cic.gc.ca/english/department/media/notices/noticelevels2013.asp

74 Immigration and Refugee Protection Act, S.C. 2001, c. 27, S. 25.2 .

75 Not exclusively Indochinese refugees.

76 Government of Canada, "Canada-Permanent Residents by Category, 1980-2014," http://open.canada.ca/data/en/ dataset/8cocbfcb-4ea4-44ed-a58a-3fbc9edd8381.

77 Treviranus and Casasola, "Canada's Private Sponsorship of Refugees Program," 186.

78 Ibid., 187.

79 Debra Pressé, director, Resettlement Cic, letter to Sponsorship Agreement Holders, 3 March 2006, 3.

80 Either by UNHCR or a foreign state "under the rules applicable to the United Nations High Commissioner for Refugees or the applicable laws of the foreign state,"
Immigration and Refugee Protection Regulations, SOR/2002-227, s. 153 (1)(b).

81 "Palestinians ex-Iraq" are Palestinian refugees who had been living in Iraq but were forced to flee Iraq to another state.

82 CIC, "Canada to Resettle 1,300 Syrian Refugees by End of 2014," news release, 3 July 2013.

83 UNHCR, "Background Note: High-Level Meeting on Global Responsibility Sharing through Pathways for Admission of Syrian Refugees" (Geneva: UNHCR, 2016), 1.

84 UNHCR, Working Group on Resettlement, "Simplification of Resettlement Procedures” (Geneva: UNHCR, 2015), 1.

85 Immigration, Refugees and Citizenship Canada, 2015 Annual Report to Parliament on Immigration (Ottawa: IRCC, 2016).

86 Judith Kumin, Welcoming Engagement: How Private Sponsorship Can Strengthen Refugee Resettlement in the European Union, EU Asylum towards 2020 Project Migration Policy Institute Europe (Brussels: Migration Policy Institute, 2015).

Michael Casasola is a resettlement officer at UNHCR Canada. The author may be contacted at casasola@unhcr.org. 


\title{
Inside/Outside the Circle:
}

\section{From the Indochinese Designated Class to Contemporary Group Processing}

\author{
ROBERT C. BATARSEH
}

\begin{abstract}
This article compares the conditions surrounding the creation of Canada's former Indochinese Designated Class and the contemporary group processing program. Under this program the UNHCR identifies and refers entire groupings of refugees for resettlement in Canada. The article also briefly touches on the selection of Tibetan refugees by Canadian officials in the late 1960 s and early 1970s. The Designated Class framework streamlined eligibility for resettlement and allowed government officials to respond to persons not covered by the narrower definition of refugee under the Convention. In a similar fashion, contemporary group processing aims to make resettlement processing efficient by skipping refugee status determinations and using group profiles. The aftermath of the Indochinese resettlement programs and the tightening of eligibility under the Indochinese Designated Class have shaped the creation of group processing. Concerns over "pull factors," economic migration, and fraud, along with the securitization of migration, have led to a preference for homogenous and self-contained groupings of refugees. The article traces the Canadian government's preoccupation with visualizing and drawing boundaries around groupings of refugees. While both group processing and the former Indochinese Designated Class aim to make resettlement processing efficient, this objective plays a more prominent role under the former, intersecting with security practices in unique ways and informing the selection of groupings of refugees.
\end{abstract}

\section{Résumé}

Cet article entreprend une comparaison des conditions influant sur la création de l'ancienne Catégorie désignée d'Indochinois du gouvernement canadien avec celles qui ont contribué au programme contemporain de traitement groupé de cas des réfugiés. Sous les auspices de ce programme, le HCR identifie et désigne des groupements entiers de réfugiés pour la réinstallation au Canada. L’article évoque également de façon brève le sélectionnement des réfugiés tibétains par des fonctionnaires canadiens durant la fin des années 60 et le début des années 7o. Le cadre des Catégories désignées avait simplifié le processus d'admissibilité pour la réinstallation et permis aux fonctionnaires du gouvernement de s'adresser aux personnes qui n'étaient pas couvertes par la définition plus étroite du statut de réfugié sous la Convention. De manière semblable, le traitement groupé contemporain de cas de réfugiés a pour objectif de rendre efficace le traitement des demandes de réinstallation en sautant l'étape de détermination de statut de réfugié et en se servant des profils groupés. L'article propose que les conséquences des programmes de réinstallation visant les Indochinois, ainsi que le renforcement des critères d'admissibilité dans le contexte de la Catégorie désignée d'Indochinois, ont influencé la création du traitement groupé de cas de réfugiés. Les préoccupations vis-à-vis des "facteurs d'attraction" pour les migrants, la migration économique, et la fraude, ainsi que la sécurisation de la migration, ont contribué à une préférence pour des groupements homogènes et bien délimités de réfugiés. 
L'article décrit la préoccupation du gouvernement canadien en matière de visualisation et de délimitation de groupements de réfugiés. Bien que le traitement groupé ainsi que l'ancienne Catégorie désignée d'Indochinois partagent le même objectif de rendre le traitement de la réinstallation plus efficace, cet objectif joue un rôle plus important dans le cas du premier, se croisant avec des pratiques de sécurisation d'une façon inédite et influant sur la sélection de groupements de réfugiés.

\section{Introduction}

T 7 istorically, states have grouped overseas refugees for resettlement, whether along the lines of nation1 ality, ethnicity, race, labour skills, vulnerability, or political ideology. ${ }^{1}$ Depending on the context, sometimes this grouping is made explicit, whereas in others it is implicit in how the state responds to refugee movements, carving out groupings of refugees. This article focuses on those moments when the Canadian government has either explicitly developed frameworks for grouping refugees for resettlement or has reflected on this process. It charts changes in this process, from an emphasis on settlement potential with the Tibetans, to a desire to streamline eligibility under the Indochinese Designated Class, and finally to contemporary obsessions over fraud, security, and the boundaries of groupings of refugees under group processing. The initially open-ended designation of eligibility for the Indochinese is contrasted to the Canadian government's current preference for much tighter definitions of group membership under group processing. Concerns over "pull factors" and economic migration towards the end of the Indochinese resettlement program as well as UNHCR reforms in the late 1990 s and early 2000 s played an important role in shaping the development of group processing in 2003. In addition, the terrorist attacks of 11 September 2001 have increased the security concerns of resettlement states. In response, the UNHCR has strengthened registration and identification practices aimed at dealing with fraud. While both the former Indochinese Designated Class and group processing aim to make resettlement processing efficient, under the latter this objective plays a central role as the state prefers self-contained and homogenous groupings of refugees that are perceived as easy to process and not a threat to the Canadian population. I argue that contemporary preoccupations with boundaries, visibility, homogeneity, and efficiency under group processing provide the Canadian state with new variables of consideration in determining which grouping of refugees is the right fit for Canada.

The article draws on a mixture of archival research and interviews with key individuals familiar with Canada's group processing. While archival research provides useful insights into the development of the Indochinese Designated Class, the Tibetan resettlement program, and official group resettlement procedures, it reveals less about how group processing decisions are made. For this reason, 11 interviews were conducted with officials from Citizenship and Immigration Canada (CIC), ${ }^{2}$ the Canadian Department of Foreign Affairs (DFAIT), ${ }^{3}$ Canadian Border Services Agency (CBSA), the United Nations High Commission for Refugees (UNHCR), and the Canadian Council for Refugees (CCR). While the empirical focus of the article is on the historical and contemporary Canadian resettlement program, it also draws on the UNHCR's group resettlement methodology. Canada played a critical role in shaping the development of this method as well as the revitalization of resettlement within the UNHCR in the early 2ooos. Additionally, the interviewing of UNHCR officials shed light on Canada's group processing program and the multilateral character of both the Bhutanese and Karen Burmese resettlement initiatives.

The article begins by briefly examining Canada's selection of Tibetan refugees in the late 1960s and early 1970s. It considers the UNHCR's and Dalai Lama's initial request to settle the Tibetans as a self-contained grouping, and the Canadian government's reluctance to do so. Despite this reluctance, concerns over the ability of the Tibetans to successfully settle in Canada shaped the government's assessment of them. Implicitly, it treated them as a grouping. The article then turns its attention to the initially positive response by Western countries to the plight of the Indochinese and the subsequent use of a loose definition of eligibility under Canada's Designated Classes to resettle them. I highlight how this regulatory framework aimed to work outside the Refugee Convention and streamline the determination of eligibility. The increasing skepticism towards the Indochinese resettlement programs in the buildup to the signing of the Comprehensive Plan of Action (CPA) in 1989 cast doubt on the openended definition of eligibility under the Designated Class. The perception of economic migrants and "pull factors" led to individual screening mechanisms to determine refugee status. The signing of the CPA coincided with the end of the Cold War, removing an important geopolitical motivation behind largescale resettlement to Western countries. During the 1990s there was an emphasis on return, as resettlement became the least-preferred durable solution. Despite this move away from resettlement, the UNHCR in the latter part of the decade began to reform its resettlement operations. By the early 200os, resettlement states such as Canada began pushing the UNHCR to increase referrals. The creation of the group processing program in 2003 took place in a context where resettlement is officially based on protection
(C) Author(s), 2016. This open-access work is licensed under a Creative Commons Attribution-NonCommercial 4.0 International license.
Cette oeuvre en libre accès fait l'object d'une licence Creative Commons Attribution-NonCommercial 4.0 International. 
needs and is targeted towards protracted refugee situations. This focus, however, is matched by state preoccupations with fraud and security risks. Under group processing, there is an emphasis in clearly visualizing and identifying homogenous and self-contained groupings of refugees. To demonstrate this, I draw on the program's pilot project in 2003 that selected groupings of Somali Madiban and Sudanese from the Dadaab refugee camp in Kenya. The article also considers the selection of the Bhutanese and the exclusion of Burundians, Rwandans, and Chechens from the program. I conclude by reflecting on the similarities and differences between group processing and the former Indochinese Designated Class. While earlier versions of the Indochinese Designated Class and contemporary group processing both aim to make resettlement processing efficient and place less emphasis on ensuring refugee status under the Convention, bureaucratic objectives are more pronounced under the latter, intersecting with security concerns in unique ways and informing the selection of groupings of refugees for resettlement.

\section{Tibetan Resettlement}

Following the annexation of Tibet by China in the 1950s, many Tibetans fled to India. ${ }^{4}$ Shortly afterward the Dalai Lama asked both Canada and Switzerland to accept Tibetan refugees. While Switzerland agreed, Canada declined. The former high commissioner to India, James George, noted that Immigration officials had concerns over the purportedly nomadic nature of the Tibetans, arguing that there was no immigration category for them..$^{5}$ George would become a key figure in Canada's eventual acceptance of the Tibetans, convincing former prime minister Pierre Elliot Trudeau to influence immigration officials to be more open to their resettlement. ${ }^{6}$ In 1966 the UNHCR attempted to persuade Canadian officials to settle the Tibetans as a "group," the hope being that this would help meet their spiritual and cultural needs. ${ }^{7}$ A year later an interdepartmental committee was formed to consider the plight of Tibetan refugees. While the committee ruled out the idea of group settlement as contrary to immigration policy, the government agreed to accept the Tibetans on an individual or family basis. ${ }^{8}$

The initial apprehension of officials over nomads and the concept of group settlement reflected concerns at the time with the settlement potential of refugees. The decision against group settlement was based on the perception that it "would hinder the permanent integration of the Tibetans into the life of the country."9 A report in 1975 by the Department of Manpower and Immigration that reviewed the Canadian resettlement program for the Tibetans highlights how immigration officials preferred refugees from towns (or settled regions of Tibetans) with some form of secondary education. Officials also felt that younger married couples with small families and single workers would be easier to integrate. In contrast, there was a belief that older refugees and those from unsettled rural areas would have trouble finding employment, be difficult to train or retrain, and slow to learn one of Canada's official languages. ${ }^{10}$ After a review of the Swiss experience with Tibetans, the interdepartmental committee in the late 1960s concluded, "Amongst the nomads the process of adaptation has been much more difficult. The nomads cling to the communal households that were set up to receive them. They are more dependent on official help and experience greater insecurity. Moreover they have a tendency to isolate themselves from Tibetans from other walks of life."11 Not surprisingly, Canadian officials selected only two nomads from Tibet. ${ }^{12}$

While the government refused to formally recognize the concept of group settlement with the Tibetans, it implicitly treated them as a grouping, assessing their education, skills levels, and ability to adapt to Canadian life. Under much different circumstances, group processing calls for the selection of self-contained groupings of refugees. In part, there is now a belief that this facilitates the integration of refugees. ${ }^{13}$ More important, the desire for self-contained and finite groupings reflects important changes in the rationale of how states approach resettlement. Understanding these changes requires consideration of the lasting influence of the Indochinese refugee movement and the eventual reform of the Designated Classes.

\section{Big Circles: The Indochinese Refugee Movement and the Evolution of the Designated Classes}

The daily media images of the plight of the Indochinese refugees in the 1970s captured the general public's attention in Western states. And while Cold War ideological and geopolitical considerations guided Canada's positive response to the Indochinese, ${ }^{14}$ so did humanitarian considerations. The international community's selection of over 350,000 Vietnamese and Laotian refugees, as well as half a million Cambodians, formalized a system of first asylum in the region for permanent resettlement elsewhere, also known as "an open shore for an open door."15 The Canadian government resettled the Indochinese under the newly created Designated Classes system, following the passing of the 1976 Immigration Act. This simplified the question of eligibility for resettlement by skipping refugee status determinations based on the Convention and focusing instead on admissibility. ${ }^{16}$ Commenting on the Indochinese Designated Class, Raphael Girard explains, "Given that none of the boat people in South East Asia were going to return to Vietnam and they could not stay any length of time in the countries of first asylum, the issue of the Convention status of the
(C) Author(s), 2016. This open-access work is licensed under a Creative Commons Attribution-NonCommercial 4.0 International license.
Cette oeuvre en libre accès fait l'object d'une licence Creative Commons Attribution-NonCommercial 4.0 International. 
individuals was not crucial to their need for resettlement. This greatly enhanced the efficiency of our selection activities in the field."17

An important objective of the Designated Class framework was to allow the Canadian government to respond to individuals in need of protection beyond the rather narrow definition of a refugee in the Convention. ${ }^{18}$ Under the Convention, and the text of the 1967 Protocol Relating to the Status of Refugees, a refugee is "a person who is outside his or her country of nationality or habitual residence; has a well-founded fear of being persecuted because of his or her race, religion, nationality, membership of a particular social group or political opinion; and is unable or unwilling to avail him- or herself of the protection of that country, or to return there, for fear of persecution."19

Tanya Basok and Alan Simmons explain that the Designated Classes framework "gave authority to the Governor-in-Council to designate a group of people who do not qualify for Convention refugee status but who are, nevertheless, threatened by political, social or religious upheavals." ${ }^{20}$ Commenting on the framework, Michael C. Lanphier points to how determinations of eligibility for resettlement could be moulded to "fit the characteristics of the particular group of displaced or persecuted persons." ${ }^{21} \mathrm{He}$ goes on to say that "the existence of the definition of three different 'Designated Classes': Indochinese, Latin American, and SelfExile (East European), each with differing specifications, indicates a distinctly innovative and flexible governmental approach in determining eligibility for selection under relaxed refugee admissibility criteria." ${ }^{22}$

It is important to note that this was not the first time that the Canadian government developed refugee policies outside the framework of the Refugee Convention. Gerald Dirks explains that one reason the Canadian government was initially hesitant to become a signatory to the Convention in 1951 was the fear that it would lose the ability to deport or exclude refugees on national security grounds. In particular, authorities were concerned about Soviet espionage and subversion. ${ }^{23}$ Cold War politics guided Canada's selection of refugees during this period, an important example being its positive response to the plight of the Hungarians in $1956-7 .{ }^{24}$ In 1969 Canada ratified the Refugee Convention and Protocol. That same year it set up a special program for Ugandan Asians. Girard notes the selection of Ugandan Asians was not affected by Canada's signing to the Convention, since, "while no one had any doubt that these victims of racial hatred were refugees, in fact most could not meet the Convention definition because they were still in their country of citizenship or usual residence."25 Girard goes on to say that whether or not the Ugandan Asians were refugees was academic, "since Idi Amin himself had defined the eligible group based on their ethnicity." ${ }^{26}$ The statements highlight how the grouping of refugees can simultaneously be inclusive and exclusive. On the one hand, the Ugandan Asians were excluded for their imputed membership in an ethnic grouping. On the other hand, this made it easier for the Canadian state to determine eligibility for resettlement.

During this same period, the Canadian government attempted to redirect the refugee program away from its focus on European refugees towards the selection of nonEuropeans. As part of this move the federal Cabinet proposed the creation of an "oppressed minority policy," which would allow the government to respond to groupings of refugees that were of interest to authorities but did not fall under the Refugee Convention definition, specifically the requirement to be outside one's country of citizenship or habitual residence. ${ }^{27}$ For different reasons then, throughout the post-Second World War period, the Canadian government has worked outside the formal framework of the Refugee Convention in its response to refugee movements. The "Designated Classes" were a continuation of this practice.

The sheer size of the Indochinese crisis and the visible urgency of the situation played a role in adopting a relatively open-ended definition of eligibility under the Designated Class framework. Canada considered Vietnamese along with Laotians, Cambodians, and Hmong who fled their countries of origin after 30 April 1975 to be ipso facto refugees. ${ }^{28}$ This amounts to a prima facie status that has historically been used in situations of large-scale displacement. ${ }^{29}$ Under this designation, each member is regarded prima facie as a refugee in the absence of evidence to the contrary. In fact, in 1984 some within the Immigration Department felt that the Indochinese Designated Class definition of eligibility was too narrow and was preventing the inclusion of individuals who had received permission to temporarily remain in countries signatory to the Refugee Convention but intended to resettle to Canada. ${ }^{30}$ Officials aimed to loosen eligibility so as to include more Indochinese.

\section{The Circle Is Getting Too Big}

As the crisis in Southeast Asia wore on, resettlement states increasingly viewed the movement of Indochinese refugees as motivated more by economic considerations than a genuine concern with safety. ${ }^{31}$ A position paper from the Indochinese Consultative Group Meeting in Ottawa in April 1988 in the lead up to signing of the Comprehensive Plan of Action (CPA) suggests that resettlement was "initially the most immediate and simplest response to relieving the burden of first asylum countries. Now it is part of the problem identified with the continued outflow as many persons are seeking resettlement for economic or family reasons rather than in response to individual persecution. To maintain
(C) Author(s), 2016. This open-access work is licensed under a Creative Commons Attribution-NonCommercial 4.0 International license.
Cette oeuvre en libre accès fait l'object d'une licence Creative Commons Attribution-NonCommercial 4.0 International. 
first asylum commitment throughout the region, resettlement must remain part of the international response but not to the exclusion of encouraging other activities designed to deter the outflow." 32

Those "other activities" were the introduction of regional refugee status determination mechanisms and the encouragement of what was at first voluntary but later on involuntary repatriation under the CPA signed in 1989. This ended the use of "blanket resettlement" ignation. ${ }^{34}$ As Sten Bronee explains, "The establishment of a procedure for determining refugee status brought an end to automatic resettlement." ${ }^{35}$

The CPA worked by using specific cut-off dates. Late arrivals to countries of first asylum in Southeast Asia would be subjected to refugee status screening mechanisms while the "long-stayers" who had been present in these countries up to these cut-off dates would continue to be automatically eligible for resettlement. An important issue for Canadian officials was to bring the Indochinese Designated Classes in line with the CPA. There was recognition that the definition of eligibility under this system was inconsistent with the introduction of screening mechanisms under the CPA. At a preparatory meeting of the International Conference on Indochinese Refugees in Kuala Lumpur in March 1989, the Canadian High Commission noted that Canada has the weakest legislative basis for dealing with the issue of non-eligible individuals. ${ }^{36}$ At that same meeting, Vietnam proposed using the Organization of African Union (OAU) definition of a refugee for screening purposes; however, the Canadian High Commission noted that this definition "is as broad as our Designated Class Regulations and Canada should not support inclusion [of it]."37 A month later, a letter to the minister of employment and immigration from the associate deputy minister/vice-chairman explains to the minister that, in light of the CPA's focus on Convention refugees, the "designated class regulations will eventually have to be reviewed, since their continued use would be both next to impossible in practical terms, and contradictory to the spirit of the common approach developed through the ICIR process." 38

The Indochinese Designated Class regulations were eventually reformed so that eligibility was restricted to Vietnamese and Laotian "long-stayers" and "screened-in" recent Vietnamese and Laotian arrivals found to be Convention refugees. 39 However, all Cambodians (both long-stayers and recent arrivals) would continue to be eligible under the regulations. ${ }^{40}$ Part of the government's communication strategy was to emphasize that "these changes will help us concentrate our efforts on the 'long stayer' population in refugee camps through Southeast Asia."41 There was a belief by some officials that the plight of the "long-stayers" would likely receive "considerable attention from the media and from interested groups in Canada." 42

Tightening eligibility under the Designated Class included closing a possible loophole for Indochinese guestworkers working in Eastern Europe. An internal government memo explains that under the revised Designated Classes the wording may allow Vietnamese, Laotian, and Cambodian guest workers in Eastern Europe to apply for benefits. The document explains that "the guestworkers left their countries of origin legally in order to work abroad. There should be no impediment to their return to Vietnam, Laos and Cambodia. In order to prevent large numbers of guestworkers from qualifying under these Regulations it is imperative the changes be made as soon as possible." 43

The closing of this loophole contrasts with the decision in 1984 that sought to expand eligibility to individuals seeking temporary protection in countries that were signatories to the Convention prior to resettling in Canada. Such was the nature of the Designated Classes, which could be reformed to meet changing circumstances and political preferences.

While the CPA certainly did not end large-scale resettlement, its introduction of screening mechanisms, measures to deter clandestine departures from countries of origin, and consideration of involuntary repatriation (the most contentious aspect of the agreement) ${ }^{44}$ reflected officials' belief that many of the remaining Indochinese were no longer genuine refugees in need of resettlement. Moreover, resettlement was increasingly viewed as a "pull factor" linked to overly broad (or loose) definitions of eligibility under systems such as Canada's Designated Classes. This can be seen in the UNHCR's reflection on the response to the Indochinese refugee crisis in its 2011 resettlement handbook: "After the CPA, the use of large-scale resettlement as a solution waned. In retrospect, the decision in 1979 to adopt blanket resettlement was seen as a major 'pull-factor' causing very large numbers of people to leave Vietnam primarily for economic and social reasons, rather than to seek protection. Meanwhile, elsewhere in the world, refugees in desperate need of resettlement suffered from lack of available places." 45

At the same time, there was a feeling by some officials that since Canada was increasingly becoming a country of first asylum it would have to scale back its resettlement numbers. At the Indochinese Consultative Group Meeting in Ottawa in April 1988 this concern was linked to the associated backlog of refugee claimants in Canada and calls to end open-ended resettlement commitments. ${ }^{46}$

The CPA also coincided with the end of the Cold War. For most of this period states relied on what Alexander Aleinikoff calls the exilic approach in dealing with the issue of forced displacement. This approach emphasized thirdcountry resettlement over the return of refugees to their
(C) Author(s), 2016. This open-access work is licensed under a Creative Commons Attribution-NonCommercial 4.0 International license.
Cette oeuvre en libre accès fait l'object d'une licence Creative Commons Attribution-NonCommercial 4.0 International. 
country of origin. Both Aleinikoff and B. S. Chimni chart its decline as beginning in the mid-1970s and taking hold in the 1980 s. $^{47}$ For Chimni, the move away from resettlement towards an emphasis on first voluntary and then later forced repatriation reflected the interests of dominant states. From their perspective, the absence of labour shortages no longer warranted large-scale resettlement. ${ }^{4}$ In addition, the end of the Cold War removed the political value in resettling large numbers of refugees fleeing communist regimes. ${ }^{49}$ In explaining the emphasis on the right of return in the 1990s, Aleinikoff notes, "From a liberal, human rights approach, the fundamental wrong done to refugees was a denial of their right to live freely in their home countries. Furthermore, forced exile violated the internationally recognized right of citizens to return to their countries of origin. From this perspective, resettlement can never be the primary remedy because it does not restore the right; rather, the 'basic solution' must solve the problem of the denial of freedoms attending exile, either by preventing the conditions that compel flight or remedying those conditions after flight."50

Aleinikoff argues that, given the entrenched practices of non-intervention into the affairs of a sovereign state, it is unlikely that developed states would attempt to rectify the human rights situations in countries of origin. For this reason, he suggests that the exilic bias is being exchanged for "policies of containment-detention of asylum seekers, visa requirements, closing opportunities for resettlement, pushbacks, and return. These policies are grounded less in a desire to breach the walls of state sovereignty than an attempt to keep Third World refugee problems from inconveniencing the developed states." 51

In a similar vein, Jennifer Hyndman points to "efforts to assist refugees closer to their homes in 'regions of origin.' This occurred first in the early 1990s through a policy of 'preventative protection' and then in the 2ooos through the externalization of asylum." 52

These external pressures influenced the UNHCR as resettlement became the least-preferred durable solution in the $1990 .{ }^{53}$ The organization came to view it as a protection tool targeted towards individuals and families who had become vulnerable in their country of asylum and therefore needed resettlement. ${ }^{54}$ Within the UNHCR there was a perception by some that resettlement was motivated by geopolitical considerations, as opposed to a genuine concern for refugee protection. 55

Despite the pressures against resettlement during this period there was some movement within the UNHCR in the latter half of the 1990s to once again raise its profile as a viable durable solution. Kristin Bergtora Sandvik points to the development of a comprehensive resettlement handbook, beginning in 1997, that set clear standards for referring refugees for resettlement. ${ }^{56}$ The organization aimed to emphasize rationality and transparency in its resettlement process in a bid to strengthen its credibility and broaden the confidence of resettlement states, refugees, and other partners. ${ }^{57}$ Sandvik explains that the idea behind the 2004 version of the handbook "was that by constructing a rigorous procedure of individual selection, within the confines of asylum and host country quotas, only 'deserving refugees' truly in need of protection would be found eligible for resettlement." 58 The reforms stemmed from a perception within the UNHCR that its previous approach to resettlement was unorganized, ad hoc, prone to fraud, and disconnected from a broader analysis of protection situations involving refugees. ${ }^{59}$ A serious corruption scandal in Nairobi in 1999-2000 that involved UNHCR staff members in the selling of resettlement spaces also contributed to the reforms in which "integrity is now a major theme of UNHCR's resettlement program." 60

By the early 2000 s there emerged a renewed belief in the usefulness of resettlement as a potential durable solution.61 It is reflected in the passing of the UNHCR Agenda for Protection (2003) and Convention Plus initiatives (2004), ${ }^{62}$ which called for the expanded use of resettlement as a durable solution, particularly for groupings of refugees. ${ }^{63}$ These broad initiatives led to the signing of the UNHCR Multilateral Framework of Understanding on Resettlement, ${ }^{64}$ which emphasized multilateral resettlement efforts focused on "protracted refugee situations" and the "strategic use of resettlement." ${ }^{65}$ Officially, the strategic use of resettlement attempts to create benefits that extend beyond the refugees being resettled, including strengthening the protection environment in the country of asylum, decongesting camps, and opening up other durable solutions such as local integration. ${ }^{66}$ The idea is to utilize resettlement in tandem with other durable solutions as part of a comprehensive approach to dealing with protracted refugee situations.

The Canadian government played an important role in these efforts during this period. Shauna Labman explains that "as co-chair of the resettlement strand of Convention Plus, Canada led the authorship of the MFU [Multilateral Framework of Understanding on Resettlement]." ${ }^{67}$ In June 2003, at a forum that discussed resettlement, the Canadian delegation tabled a discussion paper titled "Resettlement and Convention Plus Initiatives." According to Joanne Van Selm, this paper had been developed in the Working Group on Resettlement under Canadian chairmanship. This is a forum for the UNHCR and resettlement states to discuss priorities and needs in the area of resettlement. A UNHCR official noted that during this period the Canadian government was a very active chair of the Working Group on Resettlement. ${ }^{68}$ Based largely on the Canadian resettlement program, the
(C) Author(s), 2016. This open-access work is licensed under a Creative Commons Attribution-NonCommercial 4.0 International license.
Cette oeuvre en libre accès fait l'object d'une licence Creative Commons Attribution-NonCommercial 4.0 International. 
discussion paper suggested that resettlement "can be a timely and cost effective durable solution." ${ }^{69}$ Van Selm explains that the paper called for "protection-based criteria that go beyond the 1951 Convention [that] would help to make resettlement a more flexible tool."70 As noted earlier, there is a long history in Canada of developing policies that determine eligibility outside the Refugee Convention framework. The emphasis on protection-based criteria is reflected in the passing of the 2002 Immigration and Refugee Protection Act (IRPA) in Canada, which signalled a move towards a more liberal and non-discriminatory refugee system.

Part of the revitalization of resettlement during this period also stemmed from the fact that states approached the UNHCR about increasing the referrals of refugees for resettlement. The organization responded by revamping and strengthening its referral methodologies in a bid to proactively identify all refugees in need of resettlement globally as opposed to field officers being selective about referrals. ${ }^{71}$

As the discussion above demonstrates, the Canadian government played a central role in the early zooos in renewing resettlement. However, the emphasis on vulnerability, flexibility surrounding the Convention definition of a refugee, and responding to protracted situations is only part of the story. Equally important are heightened concerns by states over security and fraud. A UNHCR official recalls that, in the aftermath of the 9/11 terrorist attacks, the organization was forced to respond to these concerns by reinforcing identity and registration practices. ${ }^{72}$ At the same time, while the passing of IRPA in 2002 emphasized refugee protection, as Anna Pratt notes, it also ushered in a whole range of inadmissible classes based on forward-looking risk-management techniques. ${ }^{73}$ In a similar vein, anticipating the effects of the passing of IRPA, Casasola argued that while "ability to establish" is a decreasing problem with Canada's resettlement program, medical and security restrictions are likely to be the new obsessions. ${ }^{74}$

The character of contemporary resettlement differs from earlier largescale programs such as the Indochinese. Despite efforts to revitalize it, lasting concerns over "pull factors," combined with obsessions over fraud and security, have led to a much more limited and targeted role of resettlement. In the context of the strategic use of resettlement, these changes resonate with Mariana Valverde and Michael S. Mopas's concept of "targeted governance" and its associated reliance on risk-management techniques informed by a neoliberal rationality. ${ }^{75}$ This rationality is reflected in the drive in group processing to make resettlement processing efficient. In part, this is achieved by using shortened UNHCR resettlement registration forms (RRFs), skipping refugee status determinations (the acceptance of prima facie basis), and implementing group profiles. In this respect, group processing is similar to early versions of the Indochinese Designated Class, as both work outside the Convention and simplify the question of eligibility for resettlement. However, it differs from later versions of the Indochinese Designated Class in that it is less concerned with ensuring refugee status under the Convention than with developing clear criteria for membership in chosen groupings. Moreover, bureaucratic objectives intersect with security concerns and inform the selection of specific types of groupings of refugees viewed as ideal for efficient forms of overseas processing.

The desire for finite and homogenous groupings of refugees can be seen in the initial discussions among the IOM, UNHCR, and Canadian Immigration authorities during the group processing pilot project in 2003. The UNHCR had approached the Canadian government about resettling two groupings of refugees out of the Dadaab refugee complex in Kenya. The first was what was understood as a "distinct" group of Somali Madiban and the second was a group of Sudanese refugees. The UNHCR had determined that members of each grouping had similar refugee claims. As a result, Canada was willing to use the prima facie designation for them..$^{6}$ However, authorities insisted that the UNHCR have safeguards in the process in order to ensure there were no "imposters as part of the groups."77 A CBSA official emphasized the importance of being able to establish identity and to confirm that individuals are genuinely members of the groupings. State officials worked with UNHCR and IOM staff to verify membership in the chosen groupings. The CBSA set up guidelines of the screening process, defined the chosen groupings (i.e. who's included), and contracted the IOM to do the initial pre-screening. The same CBSA official describes the discussions that occurred between CIC and the IOM: "What we said to the IOM is, 'We want you to work with the UNHCR, and what we want you to do is to define and encapsulate this group. And once you have done that, nobody can be added afterwards and nobody can leave the group, as long as they are content to be a part of that group."'78

Demonstrating the unease that Canadian officials sometimes have with group resettlement, the same official exclaimed, "It's not just identifying the individuals. It's identifying the individual within the context of the group. Refugees are no different than anyone else. If they can inject themselves into a group, they will do that, just because they are desperate enough to get out." ${ }^{\text {79 }}$

While the IOM and UNHCR conduct numerous identification and verification exercises under group processing, from the perspective of Canada's security agencies, the organization lacks the intelligence to back these assessments. The same CBSA official quoted above refers to the UNHCR's screening practices as being based on "face value." In contrast, the CBSA purportedly has significant intelligence on
(C) Author(s), 2016. This open-access work is licensed under a Creative Commons Attribution-NonCommercial 4.0 International license.
Cette oeuvre en libre accès fait l'object d'une licence Creative Commons Attribution-NonCommercial 4.0 International. 
terrorist organizations and groups. ${ }^{80}$ For this reason, Canadian officials reverified the identities of the chosen Somali Madiban and Sudanese groupings and then compared them with the initial UNHCR list of members of both groups. This became the standard practice for Canada's group-processing program and was applied to both the Karen and Bhutanese refugee groups.

While the Bhutanese was a much larger grouping of refugees compared to the Somali Madiban and Sudanese, discussions in both the Core Group on the Bhutanese (CGB) and the more routine Working Group on Resettlement (WGR) led to the belief that this refugee population was sufficiently encapsulated, given the particular location of the camps that house them in Nepal. This in turn minimized the potential for "pull factors" and the infiltration of what were perceived as unwanted elements into the camps. The same CBSA official remarked that because Nepal was not contiguous with Bhutan, "it was a pretty encapsulated population, it was a big population, but it was essentially defined." ${ }^{81}$ In addition, CBSA and CSIS assessments had determined that the Bhutanese were not a security risk to Canada. In fact, one official referred to them as a "clean population." 82

In contrast to these chosen groupings of refugees, some are deemed problematic and are therefore excluded from the program. From the perspective of some within the Canadian security establishment, the current situation in the Dadaab refugee camp in Kenya is no longer ideal for group processing, for several reasons. First, there is a concern that this refugee population contains "threatening" elements, specifically members of the listed terrorist organization Al Shabaab. An immigration official explained, "Bottom line, we cannot claim that the entire Somali population is problem-free." 83 Second, according to this same official, the mixed nature of the refugee population in Dadaab (some are fleeing famine as opposed to persecution under the Convention) makes the current Somali refugee population in Dadaab an unlikely candidate for Canada's group processing. ${ }^{84}$ Similar concerns were found with Burundians and Rwandans, what one official referred to as the "genocide populations." The same official explains, "If we had a really problematic population (and we have had problematic populations in Africa), it's particularly people that were involved in genocide in Rwanda and Burundi. We can't touch those populations. Those are very difficult, and as a group they are more problematic than they are worth our time to try and go in and screen out the good from the bad, because there was so many of them involved at various times with respect to genocide." ${ }^{85}$

Under group processing, heterogeneous groupings of refugees with "risky" elements are excluded, as the Canadian government wishes to avoid separating "risky" from “at-risk" individuals. Such practices are viewed as running counter to the bureaucratic objectives of the program to streamline the overseas processing of groupings of refugees. Several officials used the expression "generate efficiencies" in describing this objective of group processing. ${ }^{86}$

The drive for efficiency has led to attempts by officials to anticipate whether or not group processing candidates would require lengthy security assessments. A Canadian Immigration official's remarks on CIC's reliance on the CBSA for security screening under group processing demonstrate this concern:

We only go to CBSA once we have figured that this is a population that we might be interested in, that we actually could have the capacity, the resources that we could get to them. We ask them, "Is there a real reason why we shouldn't [chose them]? Do they have flags?" If they tell us that 30 per cent of that population you are going to have to send for an in-depth clearance process, much more scrutiny, where there is a csis interview, then obviously we are not going to get any savings there, no efficiencies to be generated. People would be sitting in limbo waiting for clearance. ${ }^{87}$

An example of this occurred when Canadian officials rejected Chechens for group processing. According to the same official, "As a general rule, we've told the UNHCR, 'Don't bother referring us groups of Chechens.' The number that have been engaged in other activities, it's like every one of them would have to go through a thorough screening, the odd individual woman maybe. 'But don't come to us and say, "Would you take 500 Chechens?," because we know that all 500 we would have to really scrutinize." 88

Rather than expend the resources necessary to sort the "risky" from the "at-risk," the state avoids groupings of refugees deemed potentially "risky." Part of this process involves the examination of what the CBSA calls the "inadmissibility patterns" of refugee populations. A CBSA official explained that, on the basis of these examinations, the security agency would determine if refugee groups were good candidates for resettlement. ${ }^{89}$ This suggests that with group processing, security screening involves not only the comparison and contrasting of different groupings of refugees, but also the same grouping across different time periods. Risk-management techniques take on spatial and temporal dimensions. The "inadmissibility patterns" of earlier asylum claimants and resettlement applications from a refugee population play a role in determining the viability of offering resettlement to current refugees from the same population. The relation between the drive for efficiency and security practices under group processing has led to novel variables of consideration in determining the ideal grouping of refugees for resettlement.
(C) Author(s), 2016. This open-access work is licensed under a Creative Commons Attribution-NonCommercial 4.0 International license.
Cette oeuvre en libre accès fait l'object d'une licence Creative Commons Attribution-NonCommercial 4.0 International. 
A key document used in group resettlement schemes such as group processing is the UNHCR's Group Profile and Proposal Document (GPPD). As noted earlier, GPPDs, or group profiles, permit the use of either shortened Resettlement Registration Forms (RRFs) for chosen members of a grouping or, in the case of the United States Priority $2^{90}$ referral, the direct transmission of basic bio data without RRFs.91 Among the things included in this profile are gender breakdown of the refugee population, ethnic, religious, occupational and social background, exclusion concerns, durable solutions analysis, quality of registration, need for resettlement, and possibilities for "pull factors." The GPPD also considers how homogenous groupings of refugees are in common causes of flight, or narratives of persecution and the grouping's distinctiveness relative to the wider refugee population in refugee camps. ${ }^{92}$ Commenting on the makeup of the GPPD, Martin explains, "The objective is to identify 'finite groups' that can become the focus of resettlement efforts. Such clarity about the group's dimensions is important, both to guard against fraud and to minimize any magnet effect generated by the resettlement activity. This theme was repeated to me many times during my interviews." ${ }^{93}$

Martin points to how the group methodology reflects how to overcome opposition to resettlement by some within the UNHCR ranks, on the basis of concerns over new "pull factors." ${ }^{94}$

These concerns are reflected in the statements of a UNHCR official who explained that resettlement countries like to draw a circle around the grouping in order to know who's in it and who's not. ${ }^{95}$ The same official said, "It's like if you had perfect vision at the moment, you would know all the people that are in that group ... To give you an example, one of the group definitions would be like Eritreans of Kunama ethnicity who are in the Shemelba camp who are registered between this date and that date, so in theory, even if you don't have all those names right in front of you right then, it's a finite group." 96

The notions of "perfect vision" and "drawing circles" capture the active role that states play in crafting homogenous and self-contained groupings of refugees. This is to be achieved through multiple verification and re-verification exercises and the proactive production and analysis of group profiles. The need for such clarity of group membership differs from the earlier definitions of eligibility under the Indochinese Designated Class in which individual Vietnamese, Cambodians, and Laotians were eligible for resettlement to Canada if they could demonstrate that they left their respective countries of origin after 30 April 1975.

As noted earlier, group processing was created in a context in which states and the UNHCR sought to revitalize resettlement. In part, this move was in response to increased concerns over protracted refugee situations, or what was known in the early 2000 s as refugee warehousing. Under the strategic use of resettlement, the selection of large groupings of refugees with similar protection needs is viewed as one solution in resolving these situations. ${ }^{97}$ At the same time, the desire for "perfect vision" and "drawing circles" attempts to capitalize on the immobility of refugees caught in prolonged displacement. The perceived distinction between the heterogeneous nature of refugees in urban centres, compared to the homogeneity and immobility of camp refugees, is captured by one UNHCR official:

In a camp situation you have a group of people who are very homogenous, because they belong to the same ethnic group, they came out of the same protection situation ... so you have ... a population which is very homogenous, in terms of not only their profile, they are all the same country, same nationality, the same ethnic group, the same language, the same everything ... unlike in an urban context where you have a mixed bag of cases [in] which you have a refugee from Iran, who escaped because of religious persecution, a refugee from another country who escaped because of political activities..$^{98}$

When there are limited resettlement spaces, the decision to focus group resettlement efforts only on refugee camps has serious consequences for the millions of refugees living in urban centres. Moreover, even within the space of refugee camps, the desire for "perfect vision" and "drawing circles" is confronted with fluid situations. Hyndman's analysis of "ordering disorder" in Kenyan refugee camps points to the standardization efforts of the UNHCR that fail to account "for local historical contexts" and to refugees who resist technologies of knowing, such as headcounts. 99

The preference of resettlement states for groupings of refugees with common narratives of flight and persecution has created tensions with the UNHCR's system for determining resettlement need. States prefer to group refugees according to similar ethnicity, location, experiences of violence, or flight, while the UNHCR bases decisions on the need for resettlement in countries of first asylum. ${ }^{100}$ Given state concerns over security and fraud, as well as the UNHCR's reliance on donors, it is difficult to envision the organization challenging states on this matter. As the UNHCR has attempted to reassert the legitimacy of its resettlement operations, it has developed mechanisms to mitigate fraud and deal with potential "pull factors" in programs such as its group methodology.

\section{Conclusion}

Throughout the post-Second World War period the Canadian government has developed different frameworks for
(C) Author(s), 2016. This open-access work is licensed under a Creative Commons Attribution-NonCommercial 4.0 International license.
Cette oeuvre en libre accès fait l'object d'une licence Creative Commons Attribution-NonCommercial 4.0 International. 
grouping refugees. In many cases these worked outside the formal definition of a refugee under the Convention. While the government refused group settlement with the Tibetans, it treated them as a grouping in other ways, separating those perceived as easy to integrate and those deemed difficult. A different set of priorities was behind the creation of the Designated Classes. With the Indochinese, the concern was to make resettlement more efficient by streamlining eligibility and having the flexibility to work outside the narrow framework of the Refugee Convention. At the beginning of the Indochinese crisis, a mix of Cold War politics and humanitarian concerns supported a broad definition of eligibility for resettlement. As the crisis wore on, however, and circumstances changed, the government sought to tighten this eligibility.

The conditions surrounding the creation of group processing differ and yet were influenced by the aftermath of the Indochinese resettlement programs. Similar to earlier versions of the Indochinese Designated Class, there is less concern with ensuring refugee status based on the Convention; the state accepts the prima facie designation. This gives the Canadian government the flexibility to select groupings of refugees it desires, regardless of whether or not members of these groupings fit the narrow definition of a refugee under the Convention. However, concerns over fraud, security risks, and "pull factors" have led officials to obsess over clear criteria for membership in groupings of refugees selected for resettlement. The state is preoccupied with visualizing and drawing boundaries around groupings of refugees. Moreover, the emphasis on creating efficiencies is much more pronounced, compared to the former Indochinese Designated Class. While the Canadian government reformed definitions of eligibility under later versions of Indochinese Designated Class in response to concerns over "pull factors" and economic migrants, under group processing it avoids risky, fluid, and heterogeneous groupings of refugees. The relations between the neoliberal drive for efficiency, security practices, and the desire for homogeneity under group processing point to new variables of consideration in the Canadian state's assessment of the ideal grouping of refugees for resettlement.

\section{Notes}

1 Before proceeding, a note on terminology is in order. In what follows, the use of the term group is not taken for granted, but rather is based on considerable reflection over how to articulate the group processing process in a manner that does not presuppose the existence of "groups" of refugees. Consider, for example, the formal definitions of the terms grouping and group. According to the Merriam-Webster Dictionary, a group is defined as "a number of individuals assembled together or having some unifying relationship," whereas grouping is "the act or process of combining people or things into groups." The former assumes individuals with pre-existing commonalities (i.e. "groups"), whereas the latter emphasizes the active process through which "groups" are formed in the first place. The very label group resettlement program presupposes the groupness of those whom authorities aim to resettle. In contrast, this article examines the ways in which resettlement selection practices play a role in producing and reproducing "groups." I will refrain from using the term group because I do not want to reinforce the sense that "groups" are there for resettlement schemes to discover. I want to get at how governments do not just choose between pre-existing "groups," but the processes that they use to choose also construct them at the same time.

2 Changed to Immigration, Refugees, and Citizenship Canada under the Liberal government.

3 Changed to Global Affairs Canada under the Liberal government.

4 Valerie Knowles, Strangers at Our Gates: Canadian Immigration and Immigration Policy, 1540-2007 (Toronto: Dundurn Group, 2007), 212; Gerald E. Dirks, Canada's Refugee Policy: Indifference or Opportunism? (Montreal and Kingston: McGill-Queen's University Press, 1977), 235.

5 James George, former high commissioner to India, interviewed in Sandro Contenta, "For Tibetan Refugees, Canada Was Literally the New World," Toronto Star, 23 October 2010, http://www.thestar.com/news/world/2010/10/23/ for_tibetan_refugees_canada_was_literally_the_new_ world.html.

6 Ibid.

7 Jan Raska. "Tibetan Immigration to Canada," Canadian Museum of Immigration at Pier 21, https://www.pier21.ca/ blog/jan-raska/tibetan-immigration-to-canada.

8 W. Smith, Tibetan Refugees: A Second Life in a New Land (Ottawa: Research Projects Group, Strategic Planning and Research, Department of Manpower and Immigration, 1975). See also memorandum to Cabinet, "The Settlement of a Limited Number of Tibetan Refugee Families in Small Family Groups in Canada," 30 April 1970, Cabinet no. 611/70, Library and Archives Canada. Under the section entitled Factors, it states, "In December 1968, the Prime Minister advised the Dalai Lama that every possible avenue for the movement and settlement of Tibetan refugees as a group had been explored and the conclusion had been reached that settlement as a self-contained group would not be practicable. The Prime Minister said, however, that the migration of Tibetans on an individual or family basis would be acceptable and viewed sympathetically. The Dalai Lama was asked to indicate whether individuals or families would be interested in coming forward on this basis. If so, he was informed that we would
(C) Author(s), 2016. This open-access work is licensed under a Creative Commons Attribution-NonCommercial 4.0 International license.
Cette oeuvre en libre accès fait l'object d'une licence Creative Commons Attribution-NonCommercial 4.0 International. 
be prepared to explore further the possibility of an initial experiment. The approach suggested was accepted by the Dalai Lama in a letter dated January 8, 1969."

9 Smith, Tibetan Refugees.

10 Ibid.

11 Ibid.

12 Ibid.

13 CIC, Media Lines/Qs and As, Karen Refugee Group Processing Exercise, 26 May 2006, 3.

14 See Reg Whitaker, Double Standards: The Secret History of Canadian Immigration (Toronto: Lester and Orpen Denys, 1987).

15 Courtland W. Robinson, "The Comprehensive Plan of Action for Indochinese Refugees, 1989-1997: Sharing the Burden and Passing the Buck," Journal of Refugee Studies 17, no. 3 (2004): 320.

16 Raphael Girard, "Designated Classes: A Regulatory Device to Target Humanitarian Resettlement Programs," Canadian Immigration Historical Society, Bulletin 45, January 2005, http://cihs-shic.ca/2005/01/designated-classes/

17 Ibid.

18 Tanya Basok and Alan Simmons, "A Review of the Politics of Canadian Refugee Selection," in The International Refugee Crisis: British and Canadian Responses, ed. Vaughan Robinson (Oxford: Houndmills, Basingstoke, Hampshire: Macmillan / Refugee Studies Programme, University of Oxford, 1993), 133, 148; Michael C. Lanphier, "Canada's Response to Refugees," International Migration Review 15, nos. 1-2 (1981): 116-17; see also Girard, "Designated Classes."

19 UNHCR, "The 1951 Convention Relating to the Status of Refugees and Its 1967 Protocol" (Geneva: United Nations High Commission for Refugees, 2011), 3, http://www. unhcr.org/4ec262dfg.html.

20 Basok and Simmons, "Review of the Politics of Canadian Refugee Selection," 148.

21 Lanphier, "Canada's Response to Refugees," 117.

22 Ibid., 129.

23 Gerald E. Dirks, Canada's Refugee Policy: Indifference or Opportunism? (Montreal and Kingston: McGill-Queen's University Press, 1977), 180.

24 Ibid.; see Whitaker, Double Standards.

25 Girard, "Designated Classes."

26 Ibid.

27 "Selection of Refugees for Resettlement in Canada," memorandum to Cabinet, 27 July 1970, Cabinet document 11032770, file 1032-70, vol. 6373, RG2, Library and Archives Canada (LAC).

28 Lanphier, "Canada's Response to Refugees," 117; Basok and Simmons, "Review of the Politics of Canadian Refugee Selection," 133.

29 Bonaventure Rutinwa, "Prima Facie Status and Refugee Protection," New Issues in Refugee Research, UNHCR Working Paper 69 (2002), 1-3.
30 Proposal by executive director, Immigration, to the Canada Employment and Immigration Commission, "Extension and other minor adjustment of the Indochinese Designated Class Regulations, 2 October 1984, file 8005-21, LAC. Approved by the Commission 12 October 1984.

31 Memorandum by J. H. Taylor and L. H. Legault, legal advisor and assistant deputy minister for legal, consular, and immigration affairs, to secretary of state for external affairs, 30 May 1986, file 85-29-4-Indochina, part 1, LAC.

32 Indochinese Consultative Group Meeting, Ottawa, 7-8 April 1988, file 85-29-4-Indochina, part one, LAC.

33 Kristin Bergtora Sandvik, "A Legal History: The Emergence of the African Resettlement Candidate in International Refugee Management," International Journal of Refugee Law 22, no. 1 (2010): 29-30; see also Robinson, "Comprehensive Plan of Action."

34 Bonaventure, "Prima Facie Status and Refugee Protection," 1-2.

35 Sten A. Bronee, "The History of the Comprehensive Plan of Action," International Journal of Refugee Law 5, no. 4 (1993): 541.

36 Preparatory Meeting for the International Conference on Indochinese Refugees, Kuala Lumpur, 7-9 March 1989, file 85-29-4-Indochina, part 3, vol. 12498, LAC. At the top of this document it reads "March 9, 1989 The Canadian High Commission."

37 Ibid.

38 Nick Mulder, associate deputy minister/vice-chairman, memorandum to the minister, 10 April 1989, file 85-29-4-Indochina, part 3, vol. 12498, LAC.

39 Nick Mulder, memorandum to the immigration minister, 27 August 1990, file 8620-9, LAC.

40 Ibid.

41 Ibid.

42 Nick Mulder, Associate Deputy Minister/Vice-Chairman, Memorandum to the Minister, April 10, 1989. file 85-29-4Indochina, part 3, vol. 12498, LAC.

43 Nick Mulder to Nancy Hughes Anthony, deputy minister of privatization and regulatory affair, 16 November 1990, file 8620-9, Immigration, Refugees and Displaced Persons-General Designated Classes, LAC. The document also includes the "Regulatory Impact Analysis Statement."

44 Internal/confidential summary of "Tokyo ICG Meeting [Intergovernmental Consultations on the Indochinese Refugee Problem, Tokyo, 14-15 November 1988], 14 November Second Session," 15 November 1988, file 85-29-4-Indochina, part 2; International Conference on Indochinese Refugees, Geneva, 13 and 14 June 1989, file 85-29-4-Indochina, part 4, vol. 12498, LAC; "Basic Country Positions: Comprehensive Plan of Action," internal/confidential summary of "Tokyo ICG Meeting-November 14 Second Session," 15 November 1988; Barbara McDougall to John McDermid, Minister of State, 28 August 1990, file 8620-9, vol. 1992, Immigration, Refugees and Displaced Persons-General Designated Classes, LAC.
(C) Author(s), 2016. This open-access work is licensed under a Creative Commons Attribution-NonCommercial 4.0 International license.
Cette oeuvre en libre accès fait l'object d'une licence Creative Commons Attribution-NonCommercial 4.0 International. 
45 UNHCR, Resettlement Handbook, 2011 ed. (Geneva: United Nations High Commission for Refugees, 2011), 49.

46 Indochinese Consultative Group Meeting, Ottawa, 7-8 April 1988, file 85-29-4-Indochina, part 1, LAC.

47 T. Alexander Aleinikoff, "State-Centered Refugee Law: From Resettlement to Containment," Michigan Journal of International Law 14, no. 1 (1992): 120-38; B. S. Chimni, "From Resettlement to Involuntary Repatriation: Towards a Critical History of Durable Solutions to Refugee Problems," Refugee Survey Quarterly 23, no. 3 (October 2004): 55-73; "The Geopolitics of Refugee Studies: A View from the South," Journal of Refugee Studies 11, no. 4 (1998): $350-74$.

48 Chimni, "From Resettlement to Involuntary Repatriation," 58.

49 Andrew Shacknove, "From Asylum to Containment," International Journal of Refugee Law 5, no. 4 (1993), quoted in Jennifer Hyndman and Wenona Giles, "Waiting for What? The Feminization of Asylum in Protracted Situations," Gender, Place and Culture 18, no. 3 (June 2011): 362.

50 Aleinikoff, "State-Centered Refugee Law," 127.

51 Ibid., 134.

52 Jennifer Hyndman, "A Refugee Camp Conundrum: Geopolitics, Liberal Democracy, and Protracted Refugee Situations," Refuge 28, no. 2 (2011): 12.

53 UNHCR, Resettlement Handbook, 49; Shauna Labman, "Resettlement's Renaissance: A Cautionary Advocacy," Refuge 24, no. 2 (2007): 36; Sandvik, "Legal History," 21. Sandvik suggests that resettlement became the least-preferred durable solution as early as the mid-1980s.

54 David A. Martin, "Chapter vi: The Role of the Office of the un High Commissioner for Refugees," The United States Refugee Admissions Program: Reforms for a New Era of Refugee Resettlement (Migration Policy Institute and the Bertelsman, 8 July 2004), http://2001-2009.state.gov/g/ $\mathrm{prm} / \mathrm{refadm} / \mathrm{rls} / \mathrm{rpts} / 36066 . \mathrm{htm}$.

55 Ibid.,

56 Sandvik, "Legal History," 42-3.

57 Ibid., 43.

58 Ibid.

59 UNHCR, personal interview with author, 5 June 2012.

60 Martin, "Role of the Office of the un High Commissioner for Refugees."

61 See Labman, "Resettlement's Renaissance."

62 UnHCR, Convention Plus Core Group on the Strategic Use of Resettlement, Multilateral Framework of Understandings on Resettlement (Geneva: UNHCR, 21 June 2004); Agenda for Protection, 3rd. ed. (Geneva: UNHCR, October 2003).

63 UNHCR, Resettlement Handbook, 53; see also Martin, "Role of the Office of the un High Commissioner for Refugees."

64 UNHCR, Multilateral Framework of Understanding on Resettlement (Geneva: UNHCR, High Commissioner's Forum, 16 September 2004).

65 Ibid.
66 See UNHCR, Position Paper on the Strategic Use of Resettlement (Geneva: Annual Tripartite Consultations on Resettlement, 6-8 July 2010).

67 Shauna Labman, "At Law's Border: Unsettling Refugee Resettlement" (PhD diss., University of British Columbia, 2012), 109.

68 UNHCR, personal interview with author, 5 June 2012.

69 Joanne Van Selm, "The Strategic Use of Resettlement: Changing the Face of Protection?," Refuge 22, no. 1 (2004): 46.

70 Ibid.

71 UNHCR, personal interview with author, 23 June 2011.

72 UNHCR, personal interview with author, 5 June 2012.

73 Anna Pratt, Securing Borders: Detentions and Deportation in Canada (Vancouver: UBC Press, 2005).

74 Casasola, "Current Trends and New Challenges," 81.

75 Mariana Valverde and Michael S. Mopas, "Insecurity and the Dream of Targeted Governance," in Global Governmentality: Governing International Spaces, ed. William Walters and Wendy Larner, 233-50 (London: Routledge, 2004).

76 Shauna Labman explains, "To overcome the legislative requirement for individual refugee assessments, the Minister's discretion in section 25 of IRPA to grant an exemption from the Act was used to declare the Sudanese and Somalis as prima facie refugees and vulnerable. This permitted CIC to use a singular claim for each group and exempted the refugees from the 'ability to establish' requirement." Labman, At Law's Border, 219.

77 CBSA, personal interview with author, 6 October 2011.

78 Ibid.

79 Ibid.

8 o Ibid.

81 Ibid.

82 CIC, personal interview with author, 21 July 2011.

83 Ibid.

84 Ibid.

85 CBSA, personal interview, 6 October 2011.

86 I encountered the expression "generating efficiencies" in several interviews with officials from CIC, CBSA, and DFAIT.

87 CIC, personal interview with author, 21 July 2011.

88 Ibid.

89 CBSA, personal interview, 3 November 2011.

90 Groups of special humanitarian concern identified by the Us refugee program

91 UNHCR, Resettlement Handbook, 233-4.

92 Ibid., 233-41; ibid. (2004 ed.), chap. 7; UNHCR, Group Profile and Proposal Document, Bhutanese Refugees in Nepal for Group Resettlement Referral to the United States (6 June 2007); UNHCR, Group Profile \& Proposal Document, Myanmar Refugees in Mae La Oon Camp, Thailand (April 2006).

93 Martin, "Role of the Office of the Un High Commissioner for Refugees."

94 Ibid. 
95 UNHCR, personal interview with author, 28 August 2012. 96 Ibid.

97 CCR, personal interview with the author, 2 August 2012; see also Labman, At Law's Border, 218.

98 UNHCR, personal interview with author, 5 June 2012.

99 Jennifer Hyndman, Managing Displacement: Refugees and the Politics of Humanitarianism (Minneapolis: University of Minnesota Press, 2000), 117-47.
100 UNHCR, personal interview with author, 28 August 2012.

Robert C. Batarseh is a PhD candidate in the Political Science program at York University. The author may be contacted at robertbatarseh@gmail.com. 


\title{
Private Sponsorship: \\ Complementary or Conflicting Interests?
}

\author{
SHAUNA LABMAN
}

\section{Abstract}

Canada's Private Sponsorship of Refugees Program commenced before the Indochinese refugee flow began, and it has continued for almost 40 years since it subsided. Although conceived of as a complementary partnership, private sponsorship plays out more as a tug-of-war between the conflicting interests of government and sponsors over selection control and numbers. While guided by additionality, sponsors have been confronted with administrative and regulatory changes that challenge them to do more with less, and the fear that overall Canadian resettlement will reduce if their efforts are not expanded. A federal election and change of government in October 2015 may have reset government-sponsor relations but highlights the vulnerability and interpretative malleability of the program. With the pillars of the Indochinese and now Syrian resettlement efforts bookending the analysis, the article provides a historical and contextual understanding of recent changes to private sponsorship and the tensions and conflicting interests in maintaining a voluntary program premised on the resettlement of additional refugees.

\section{Résumé}

Le Programme de parrainage privé de réfugiés du Canada avait débuté avant l'influx des réfugiés indochinois, et a continué d'exister pendant presque 40 ans depuis la fin de cet influx. Le parrainage privé, bien que conçu comme un partenariat complémentaire, se manifeste en réalité plutôt comme un tiraillement constant entre les intérêts contradictoires du gouvernement et ceux des répondants en ce qui concerne la sélection et le nombre de réfugiés. Malgré le fait que les répondants sont régis par le principe d'additionnalité, ils font face à des changements administratifs ainsi que règlementaires qui exigent qu'ils fassent davantage avec moins de ressources, et se trouvent confrontés à la crainte qu'il se produise une réduction générale dans le nombre de réinstallations au Canada s'ils ne redoublent pas l'ampleur de leurs efforts. L'élection fédérale et le changement du gouvernement en octobre 2015 a sans doute relancé les relations entre le gouvernement et les répondants, mais cela souligne en même temps la vulnérabilité ainsi que l'ambiguité d'interprétation qui caractérise le programme. Avec les piliers des initiatives de réinstallation des réfugiés indochinois dans le passé et ceux des réfugiés syriens dans le présent servant comme balises aux deux extrémités de l'analyse, l'article fournit une perspective historique et contextuelle des changements récents au parrainage privé, et des tensions ainsi qu'intérêts contradictoires qui résident dans le maintien d'un programme volontaire fondé sur le principe d'additionnalité pour la réinstallation de réfugiés supplémentaires.

In the meantime, we would ask that all members of the House reach out to private sponsors and sponsorship agreement holders across this country to make sure that we fill the 1,300 places available.

-Chris Alexander Minister of Citizenship and Immigration, 27 February 2014

$\mathrm{P}$ rivate sponsorship is unique to Canada. Created out of the will of individual Canadians to help refugees and those in need, it was made possible through the willingness of Canadian politicians and immigration officials. The formal program was conceived of almost 40 years 
ago as a complement to the Canadian government program of refugee resettlement. Resettlement is itself situated as a voluntary complement to the government's commitment in international and domestic law to the concept of refugee asylum and the principle of non-refoulement. ${ }^{1}$ Resettlement represents the recognition that not all refugees can access asylum and that certain geographic regions face greater refugee flows than others. For private sponsors, their efforts are framed in the concept of "additionality"-making resettlement available to additional refugees beyond government commitments.

This article traces private sponsorship from its origins in advance of the Indochinese crisis of the 1970s to Canada's Syrian resettlement response in December 2015. Sponsors rely on the government to facilitate their sponsorships as much as the government relies on sponsors to contribute to Canada's humanitarian commitments. Yet, as a voluntary program designed through policy and regulation but no legal obligation, there is an interpretative malleability to the government-sponsor relationship that can lead in different directions, depending on the predilections of the government in power. In recent years resettlement and sponsorship experienced more focused government attention than in the program's entire history. Policy and regulatory changes culminated in a state of flux and arguable crisis. Sponsors faced requests to do more with less, and the threat that overall Canadian resettlement would reduce if their efforts were not expanded. The complementarity of the model risks collapse as it is weighed down by conflicting interests and compromise. With the unfolding of the Syrian tragedy and a change in the Canadian government in 2015, the moment of crisis seemingly abated, but maintenance of private sponsorship's complementary role remains the continual challenge. Additionality can too easily devolve into a relationship of over-reliance and dependence.

\section{Beginnings}

Canada was a country of resettlement long before it became a country of asylum. Through the International Refugee Organization, Canada took in over 100,000 resettlement refugees in the late 1940 s. $^{2}$ This was followed by the admission of approximately 37,000 refugees from Hungary in 1956 and 1957, 11,000 from Czechoslovakia in 1968, and 7,000 Asians expelled from Uganda in 1972.3 Admissions were based on ad hoc decisions and orders-in-council. ${ }^{4}$ They were also clearly ideological, strategic, and entirely selective. 5 However, alongside these mass movement resettlements, individual Canadians were angling to facilitate admissions on a smaller scale.

Both the Mennonite Central Committee (MCC) and the Jewish Immigrant Aid Services (JIAs) of Canada were founded following the First World War to assist in immigration to Canada. ${ }^{6}$ During the Second World War other religious collaborations followed, such as the Canadian Christian Council for the Resettlement of Refugees (1946), the Approved Church Program (1953), and the National Inter-Faith Immigration Committee (1968), to bring in and support additional refugees and displaced persons. 7 These initiatives stood in contrast to Canadian government action on refugee protection. While supporting the United Nations High Commissioner for Refugees (UNHCR) financially since its inception, ${ }^{8}$ playing a lead role in the drafting of the 1951 Convention relating to the Status of Refugees (1951 Convention), 9 and serving on UNHCR's Executive Committee, Canada did not ratify the 1951 Convention or its 1967 Protocol relating to the Status of Refugees until 4 June $1969 .{ }^{10}$ The Canadian government was reluctant to give up absolute sovereign control of its borders that the 1951 Convention requires for refugee admissions. Nor did Canada consider itself a country of first asylum. ${ }^{11}$

Canada's eventual decision to ratify the 1951 Convention presented an opportunity for broader reform of Canadian refugee law. In Canada, a ratified international treaty must be implemented through domestic law to be enforceable. The Canadian government therefore needed to revise its immigration legislation to reflect Canada's acceptance of the 1951 Convention obligations and announced plans to design a new Immigration Act in September $1973 .{ }^{12}$ The legislative review process presented an opportunity for religious groups to lobby for the formalization of the private sponsorship they essentially already facilitated. In 1973, Joseph Kage, national executive vice-president of JiAs, suggested that in looking to revise the Immigration Act, "consideration be given to provisions which would enable individuals or responsible voluntary social agencies to offer sponsorship or co-sponsorship in deserving cases of refugees or other immigrants, which would come under the category of 'humanitarian immigration."'13 Even earlier, in 1967, Kage was pushing for sponsorship. Commenting on the government's 1966 white paper on immigration, Kage wrote, "We also suggest that consideration be given to provisions which would enable individuals or responsible voluntary social agencies to offer sponsorship or co-sponsorship to deserving cases of refugees." 14 For the first time in Canadian law, the 1976 Immigration Act contained provisions for the private sponsorship of refugees (PSR) alongside governmentassisted refugees (GARS). ${ }^{15}$

Private sponsorship was structured to occur through a "Group of Five" or through organizations holding "master agreements" with the government that limited the government's direct involvement with sponsoring groups. ${ }^{16}$ The underlying structure of private sponsorship has remained
(C) Author(s), 2016. This open-access work is licensed under a Creative Commons Attribution-NonCommercial 4.0 International license.
Cette oeuvre en libre accès fait l'object d'une licence Creative Commons Attribution-NonCommercial 4.0 International. 
relatively consistent over the intervening years. There are close to 100 Sponsorship Agreement Holders (sAHs) across Canada. ${ }^{17}$ What has shifted over time is the nature of the sponsorship applications. The program, as conceived, was to formalize the already occurring sponsorships of known individuals to be supported by groups such as JiAs and the MCC. ${ }^{18}$ The legislation came into force as media attention and public outrage grew over the worsening Indochinese "boat people" crisis of the late 1970s. Government officials used the sponsorship provisions as a means of directing engaged Canadians to action. ${ }^{19}$ Interest exploded, and private sponsorship shifted from the resettlement of fewer than 100 known refugees by the spring of $1979^{20}$ to the resettlement of 34,000 privately sponsored Indochinese between 1979 and 1980. ${ }^{21}$ Unlike the earlier wartime efforts that created the push for the program, the Indochinese sponsorship was primarily a sponsorship of strangers. There was no real Indochinese base in Canada. As the crisis subsided, a thriving sponsorship community had clearly arisen across Canada, but the nature of this sponsorship would shift with the interests of the sponsors.

In 1990 the government commenced a review of the sponsorship program. ${ }^{22}$ The resulting report pointed to concern that the program was turning into a supplementary tool for expanded family reunification. The sponsorship structure permits sponsors to either "name" the individuals they wish to sponsor or accept a referral from a visa officer of an individual requiring sponsorship. The ability to specify an individual for sponsorship is understandably appealing and grew as the sponsoring community itself grew with incoming refugees. Tom Denton notes, "Among the refugee-sponsoring community, the demand for familylinked sponsorships is seen as being effectively without limit, because for every refugee who arrives sponsors estimate that at least two more sponsorship requests are generated." ${ }^{23}$ The access that sponsorship provides to broader family reunification heightened when the government cancelled the Assisted Relative class in 2002. ${ }^{24}$ The Assisted Relative class reached beyond the immediate family class (spouse or partner, dependent child, parent, or grandparent ${ }^{25}$ to include extended relatives (uncle or aunt, brother or sister, nondependent son or daughter, nephew or niece, grandson or granddaughter). ${ }^{26}$ By 2003 some estimates put nominations of extended family or close friends at between 95 and 99 per cent of private sponsorship referrals. ${ }^{27}$ Sponsorship looked drastically different from the Indochinese movement of strangers. Additionality was operating but failing to complement government efforts as intended. Naming refugees to sponsor as opposed to government referrals requires the further step of government approval. There has been a high refusal rate of sponsor-referred names (averaging 49 per cent between 1998 and 2007). ${ }^{28}$ Refusals drain resources without achieving resettlement, further thwarting additionality.

\section{Reclaiming Control and Constraining Sponsorship}

The government made attempts to reclaim control of the sponsorship program while encouraging increased refugee sponsorship, often as a trade-off for government assistance. A series of pilot projects with slightly different parameters of blended responsibility sharing were negotiated between the government and sponsoring groups. Blending of private and public support commenced with Project Focus Afghanistan. The project resettled 1,80o Afghan Ismaili refugees between 1994 and 1998. The government provided the first three months of settlement support, with private sponsors using this time to fundraise for the remaining nine months of support-a $3 / 9$ model. ${ }^{29}$ Sponsors selected the refugees, but the cases were counted as GARs. A Special 3/9 Sponsorship Pilot Program for refugees from the former Yugoslavia was similarly designed but with the referrals coming from the government. $3^{\circ}$ With the Sierra Leonean community in 2001, the government offered a $4 / 8$ model where the community could name its own referrals. The Anglican Primate reached a similar agreement with the government in 2009 that likewise followed this $4 / 8$ financial sharing. ${ }^{31} \mathrm{~A}$ blended $3 / 9$ program for Iraqi refugees was announced in March 2011. Another blended 3/9 project with Rainbow Refugee Committee was announced the following week for the sponsorship of lesbian, gay, bisexual, transgendered, and queer/ questioning (LGBTQ) refugees. ${ }^{32}$ This program was extended for an additional two years in March 2015. ${ }^{33}$ A further form of blended support, the Joint Assistance Sponsorship (JAs) program, is included with GAR numbers, but private sponsors provide supplemental, non-financial support to vulnerable refugees with special needs. 34

As the government's agreements with community groups increased, so too did efforts to constrain sponsorship in other directions. The government placed administrative caps on sponsorship submissions by SAHS in 2011 and 2012, with the intended goal of better management. The caps were both global and specific, targeting specific missions (Nairobi, Pretoria, Islamabad, and Cairo), thereby limiting sponsor ability to respond to specific refugees. 35 This was accompanied in December 2011 with regulatory changes to formalize application procedures and limit eligibility for Group of Five and Community Sponsorships to refugees recognized by UNHCR or a state. ${ }^{36}$ Other changes have less directly but still significantly challenged the continuance of private sponsorship. An entire resettlement class, the Source Country class-which recognized certain states where individuals met the refugee definition but were not outside of their home country-was repealed in 2011, highlighting
(C) Author(s), 2016. This open-access work is licensed under a Creative Commons Attribution-NonCommercial 4.0 International license.
Cette oeuvre en libre accès fait l'object d'une licence Creative Commons Attribution-NonCommercial 4.0 International. 
the vulnerability of all resettlement programs to shifting government interests. ${ }^{37} \mathrm{~A}$ reduction in the age of dependents for all immigration classes from under 22 to under 19, announced in 2013, came into effect 1 August 2014, limiting the family members who attach to a sponsorship. $3^{38}$ Whom sponsors could sponsor was increasingly limited.

In addition, in the spring of 2012, the government reformed the Interim Federal Health Program (IFHP) through two orders-in-council. 39 The origins of the program begin in a 1952 order-in-council designed to address the emergency medical needs of those in refugee-like situations following the Second World War. ${ }^{\circ}$ While the program evolved and shifted over the following 60 years, in 2012 it provided health-care coverage to protected persons, government-resettled refugees, privately sponsored refugees, refugee claimants, and refused refugee claimants whose negative decisions were under judicial review or appeal or who were awaiting removal from Canada. Coverage extended until provincial or territorial coverage triggered or the individual left Canada. The 2012 reforms created a tiered system of coverage. Most significant for a discussion of resettlement is that before the 2012 reforms, the IFHP provided basic health coverage, as well as supplemental coverage for prescription drugs, dentistry, and vision care for all resettled refugees. The reforms reduced privately sponsored refugees to services only "if they are of an urgent or essential nature," whereas government-assisted refugees retained extended coverage equivalent to that under provincial and territorial benefits. ${ }^{41}$

Hospitality House Refugee Ministry, a leading sponsorship group based in Winnipeg, Manitoba, challenged the reforms in Federal Court, alleging that the order-in-council breached the contract between the saHs and Citizenship and Immigration Canada (CIC)..$^{2}$ Their underlying concern was that sponsors would now be responsible for the differential health-care costs. ${ }^{43}$ The application failed. Justice O'Reilly found that the agreement did not specify the level of funding to be provided, there was no evidence the order was enacted without regard to sponsors' interests, and even if there was a breach of contract, the breach would give rise to an action for damages but would not invalidate the order by way of application to the Federal Court. Sponsors were left vulnerable to the whim of government change.

While the Hospitality House application was specific to SAHs, another broader Federal Court challenge on the constitutionality of the reforms succeeded in July 2014. Justice Mactavish held the reforms constitute "cruel and unusual treatment" in violation of section 12 of the Canadian Charter of Rights and Freedoms and violate section 15 of the Charter in the differential treatment between refugee claimants from Designated Countries of Origin and those from non-Designated Countries of Origin. The decision gave the federal government four months to remedy the cuts before a declaration of invalidity was triggered. The minister of citizenship and immigration, Chris Alexander, immediately indicated that the decision would be appealed. ${ }^{44}$ On 5 November 2014, at the four-month deadline and having been denied a stay, ${ }^{45}$ the government reluctantly instituted a new Federal Health Program, described as "temporary health-care measures . . . consistent with the Federal Court's ruling." ${ }^{36} 6$ The new measures were not as extensive as the pre-2012 changes and remained tiered in the offering of coverage to different refugee categories. The applicants, arguing that the interim measures failed to meet the identified Charter violations, returned to Justice Mactavish requesting further orders for direction and clarification in relation to the 4 July 2014 order as well as an order compelling the government to comply with the judgment. Justice Mactavish held the requests to be beyond her jurisdiction, given the finality of her original ruling. ${ }^{47}$ The interim measures denied privately sponsored refugees coverage for prescription drugs or supplemental health coverage, both of which remained covered for GARs.

\section{Shifting Responsibility}

Seen in their totality, the changes directly to and affecting private sponsorship highlight a clear divide and increasing animosity between refugee advocates and government refugee policy. Private sponsors in particular have been constrained by the recent regulatory and administrative changes. While the government continued to corner sponsors, it also shifted more responsibility and expectation onto the sponsorship community. In CIC's 2009 annual report to Parliament, the minister highlighted a doubling of privately sponsored Iraqi refugees accepted over the following five years. ${ }^{48}$ In 2010, the government prefaced the legislative package to reform Canada's refugee law with an announced increase to Canada's resettlement program of up to 2,500 spaces per year. ${ }^{49}$ The increase allotted 500 more spaces to government resettlement, with the remaining 2,000 spaces open for private sponsorship. This made sponsors responsible for 80 per cent of the increase. With the 2012 Budget, the government shifted 1,00o refugee spaces from the government-assisted program to private sponsors. $5^{\circ}$ In 2013, the government announced an initial commitment to resettle 1,300 Syrian refugees by the end of $2014^{51}$ This number included 200 GARS, with the remaining 1,100 refugees expected to arrive through private sponsorship over and above the current spaces in the program..$^{2}$ The private sponsorship commitment, made on behalf of sponsors by the Canadian government, was the fifth-largest confirmed pledge for the admission of Syrian refugees received by
(C) Author(s), 2016. This open-access work is licensed under a Creative Commons Attribution-NonCommercial 4.0 International license.
Cette oeuvre en libre accès fait l'object d'une licence Creative Commons Attribution-NonCommercial 4.0 International. 
Table 1. GARs/PSRs ranges and landings 2001-2014

\begin{tabular}{|c|c|c|c|c|c|c|c|c|}
\hline \multirow[b]{2}{*}{ Year } & \multicolumn{3}{|c|}{ GAR } & \multicolumn{3}{|c|}{ PSR } & \multicolumn{2}{|c|}{ Total } \\
\hline & Ranges & Actual & $\%$ change & Ranges & Actual & $\%$ change & Actual & $\%$ change \\
\hline 2001 & 7,300 & 8,679 & & $2,800-4,000$ & 3,576 & & 12,255 & \\
\hline 2002 & 7,500 & 7,505 & -14 & $2,900-4,200$ & 3,041 & -15 & 10,546 & -14 \\
\hline 2003 & 7,700 & 7,508 & 0 & $2,900-4,200$ & 3,252 & 7 & 10,760 & 2 \\
\hline 2004 & 7,400 & 7,411 & -1 & $3,400-4,000$ & 3,116 & -4 & 10,527 & -2 \\
\hline 2005 & $7,300-7,500$ & 7,424 & o & $3,000-4,000$ & 2,976 & -4 & 10,400 & -1 \\
\hline 2006 & $7,300-7,500$ & 7,326 & -1 & $3,000-4,000$ & 3,337 & 12 & 10,663 & 3 \\
\hline 2007 & $7,300-7,500$ & 7,572 & 3 & $3,000-4,500$ & 3,588 & 8 & 11,160 & 5 \\
\hline 2008 & $7,300-7,500$ & 7,295 & -4 & $3,300-4,500$ & 3,512 & -2 & 10,807 & -3 \\
\hline 2009 & $7,300-7,500$ & 7,425 & 2 & $3,300-4,500$ & 5,036 & 43 & 12,461 & 15 \\
\hline 2010 & $7,300-8,000$ & 7,264 & -2 & $3,300-6,000$ & 4,833 & -4 & 12,097 & -3 \\
\hline 2011 & $7,400-8,000$ & 7,363 & 1 & $3,800-6,000$ & 5,584 & 16 & 12,947 & 7 \\
\hline 2012 & $7,500-8,000$ & 5,412 & -26 & $4,000-6,000$ & 4,225 & -24 & 9,637 & -26 \\
\hline 2013 & $6,800-7,100$ & 5,661 & 5 & $4,500-6,500$ & 6,269 & 48 & 11,930 & 24 \\
\hline 2014 & $6,900-7,100$ & 7,573 & 34 & $4,500-6,500$ & 4,560 & -27 & 12,133 & 2 \\
\hline
\end{tabular}

Sources: CIC, Summative Evaluation of Sponsorship, 3.2.1 (2001-6 ranges); CIC, 2007-14 annual reports to Parliament on immigration (2007-14 ranges); CIC, Facts \& Figures 2010 (2001-5); CIC, Facts \& Figures 2014 (2005-14).

Note: Figures 1-3 are based on this table.

UNHCR by June 2014, behind pledges by the United States, Germany, Austria, and Sweden.53 The Canadian government promise meanwhile ranked tenth.

Despite a seemingly continual stream of announced increases to refugee resettlement over the past few years, the actual arrival numbers show a decline. The 2010 announcement of a 2,500 increase amounted to a promised expansion of the resettlement program by 20 per cent. Ultimately there was a drop in resettlement numbers by 26 per cent between 2011 and 2012. In its 2013 annual report, the government explained the 2012 numbers: "Many of CIC's visa offices were affected by instability and heightened security concerns in some parts of the Middle East and Africa."54 Even if this explanation is accepted, by 201142 per cent of resettled refugees were privately sponsored. In comparison, between 2001 and 2008 government resettlement numbers were approximately double private sponsorship numbers, whereas by 2013 the ranges were almost equivalent for each program. The 2013 annual report, did state, "CIC continues to maintain its commitments under the Balanced Refugee Reform Act to increase the annual number of refugees resettled from abroad to as many as 14,500 refugees by 2013 ." Total 2013 resettlement amounted just over 12,00o, and no similar statement of commitment was made in the 2014 annual report. 55

Government resettlement and private sponsorship from 2001 to 2014 is charted in table 1 , as well as the percentage yearly change in admission. Overall resettlement between the two groups differs by just over 100 admissions between 2001 and 2014, but how the numbers fall between sponsors and the government differs significantly. Between 2001 and 2013, the trend was a general decline in government numbers (from 8,679 in 2001 to 5,661 in 2013), while sponsorship numbers almost doubled (from 3,576 in 2001 to 6,269 in 2013).

A similar graphing of GAR and PSR numbers until 2013 in a Library of Parliament research publication on resettlement surmises, "As most of the government's increase to the resettlement target is allocated to private sponsorship (2,000 out of 2,500 spots), the trends evident in Figure 1 are likely to continue." ${ }^{56}$ And yet, this was more than a "trend." It was an intentional and significant reallocation of resettlement numbers from government to private citizens.

The 2014 numbers show a significant drop (27 per cent) in private sponsorship while government numbers realigned with earlier years, hovering between 7,000 and 8,000. The government can increase quotas and announce grand expansions, but it remains up to individual Canadians to voluntarily take on the personal and financial responsibility to sponsor. The Canadian Council for Refugees (CCR) notes, "Canadians have a range of reasons for getting involved in sponsorship, but often a sense of personal connection with a particular region or individual is key (which is why named sponsorships are so important). It is not so clear how broad the motivation is to resettle refugees based on government priorities, particularly if there is a perception that sponsors 


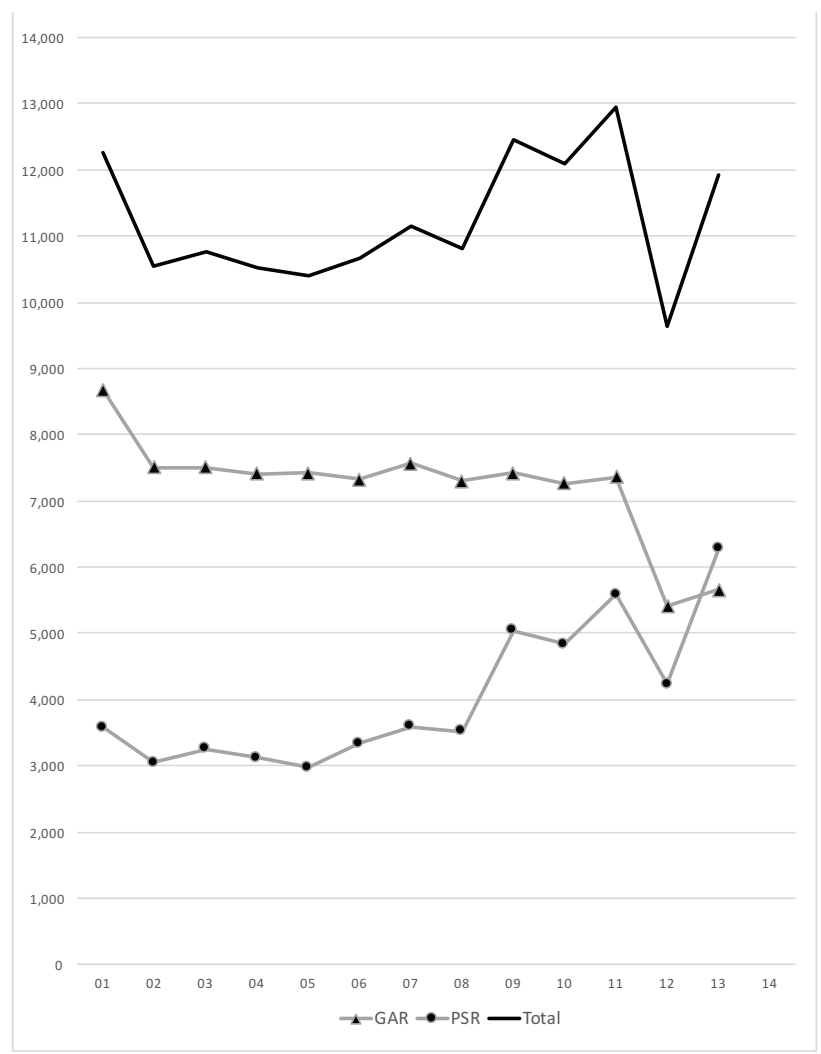

Figure 1. GAR, PSR, and total

are being asked to fill in the gap created by government cutbacks." 57 Additionality depends on the will of sponsors.

A little over a year after the announced doubling of Iraqi refugees, the government offered up the blended 3/9 program for Iraqi refugees, seemingly to encourage the sponsorship it had previously promised and still needing to "fill in the gap." Following the multiple and various pilot projects, the government launched the Blended Visa Office-Referred Program (BVOR) in 2013.58 The program increases the amount of government support from earlier pilot projects but takes back the control over naming that many of the earlier blended models left with sponsors. The program matches private sponsors with refugees referred for resettlement by the United Nations under a cost-sharing model where the government splits financial support with sponsors, each covering six months. As well, the referred refugees are "travel-ready," which means that rather than waiting years for processing, refugees arrive in Canada within one to four months.59 Resettled refugees in this category still receive full IFHP coverage. ${ }^{60}$ While constraining private sponsors' ability to sponsor the refugees they choose, the BVOR program offers the carrot enticement of less financial obligation, more support and faster arrivals. But it requires sponsors to bite and sacrifice the principle of naming with a program that further blurs additionality.

In the first year, the plan was to resettle 200 Iraqi, Iranian, Burmese, Eritrean, and Bhutanese refugees through BVor. ${ }^{61}$ BVOR targets in 2014, increased to 500, were placed not on refugees but on visa offices in Amman, Ankara, Beirut, Cairo, Nairobi, Singapore, and Bogota.62 Actual 2013 numbers totalled 153 and increased to only 177 in 2014. ${ }^{63}$ By 2015, the government goal was to match between 700 and 1,000 refugees with sponsors each year through the program.64 The 1,000 BVOR allocation replaced an equivalent number of GARS moved out in the 2012 Budget. ${ }^{65}$ In a five-minute promotional video for the new program put out by CIC, the narrator begins: "The Government of Canada has introduced a unique program to help refugees. The Blended Visa Office-Referred program makes it easier for private sponsors to provide support ... to refugees in need." The video ends with a refugee speaking directly to the camera: "I want to send message for them. Please, there's many families that are looking for hope to ... to help them." ${ }^{\text {"66 }}$ Ostensibly, this message is speaking to private sponsors.

Sponsors are clearly aware of the protection needs of refugees. Engaging in hands-on and direct settlement assistance, they are the voice of support and advocacy in Canada. The program immerses Canadians in the personal experiences of refugees. ${ }^{67}$ Refugees constitute their friends, family, and community. The video's plea, through its own rhetoric and projection of the refugee, is questionable. It implies that it is the responsibility of private Canadian citizens, rather than the Canadian government, to provide the humanitarian response to protection needs. James Hathaway pointedly notes, "The government should not be permitted to make the implementation of its international burden-sharing obligation largely dependent on the goodwill of the private sector." ${ }^{\prime 8}$ Catherine Dauvergne suggests, "Private sponsorship both allows the government an easy response to domestic pressure to act more humanely and allows it to withdraw from direct responsibility for admission totals ... the obligation is privatized and thus the responsibility of the nation is drastically reduced." ${ }^{\prime \prime} 9$ These concerns are not new, they are the continual challenge of the government-sponsorship relationship.

When the government added sponsorship provisions into the regulations in the 1970s, church groups expressed concern that "the government intended to use the plan as a means of dumping its responsibilities for refugees onto the private sector."7o In the midst of the Indochinese sponsorship, when the government seemingly reneged on a promise to match private sponsorship on a one-to-one basis, ${ }^{71}$ the Standing Conference of Canadian Organizations 
Concerned for Refugees sent a letter in December 1979 to Prime Minister Joe Clark, Minister of External Affairs Flora MacDonald, Secretary of State David MacDonald, and Immigration Minister Ronald Atkey, stating, "We are not prepared to release the government from its obligations." 72 The idea of private sponsorship, from the outset, was one of additionality. Additionality is the shield that protects against the over-reliance and dependence that Hathaway, Dauvergne, and others fear in the privatized offering. Even in 1979 when sponsor-government relations were straining, Employment and Immigration Canada put out a fact sheet for sponsorship that read, "Canadian groups and organizations who are prepared to act as sponsors, supplying the more personalized settlement services needed by displaced and persecuted people, will have a direct influence on the total number of refugees that can come to Canada. This is because refugees assisted in this way are admitted over and above those planned for in the government's annual refugee resettlement plan."73 Government documents continue to recognize this principle of additionality. The Guide to Private Sponsorship states, "Canadian citizens and permanent residents are able to provide additional opportunities for refugees." 74 Yet, after almost 40 years of negotiating their role, sponsors still must reassert additionality.

With low 2014 sponsorship numbers and less than half of the 500 target for BVors met, fears that overall Canadian resettlement would reduce if sponsor efforts were not expanded seemed well-founded. The goal of additionality risks backfiring into a reduction of resettlement numbers: "If private sponsors are unable to meet the targets set by government for blended sponsorships, it has been suggested that the places will go unfilled. Private sponsors are thus put in the unenviable position of needing to work hard to ensure that refugees don't end up deprived of the opportunity for safety and a new life in Canada. Far from adding to the government's numbers of refugees resettled, private sponsors seem to be responsible for ensuring that the government's numbers are not reduced!"75 The concern with the privatization of a responsibility that rests with the state is heightened by the recollection that private sponsorship is particular to Canada. Resettlement is regarded by UNHCR as not only a tool of protection but as a mechanism for international burden or responsibility sharing. ${ }^{76}$ Sponsorship serves not only as a response to domestic pressure but as a response to other states and international calls. As other governments offer support, is it ever right for the Canadian government to point to its private citizens to answer the call?

\section{Syria}

The current unrelenting flow of refugees from Syria echoes the Indochinese need for a response beyond direct asylum.
It is also a strong and recent example of the tendency for the Canadian government to turn to sponsors in response to both domestic questions on Canada's commitments and international calls for humanitarian assistance. In May 2013, an emergency debate on Syria was conducted in the House of Commons. ${ }^{77}$ Questions on resettlement were raised, but UNHCR had not yet recommended that states engage in this solution. In July 2013, the Canadian government announced its intention that 1,300 Syrian refugees would be resettled to Canada by the end of $2014 .^{78}$ UNHCR had requested the resettlement of urgent and vulnerable cases, and Canada committed to resettle 200 vulnerable refugees through the GAR program in 2013 and 2014. The remainder of the announced commitment, 1,100, was to occur through private sponsorship. The CCR responded, "This is causing some surprise as it is not known that any private sponsors had individually or collectively signalled their capacity to take on this number of sponsorships (which represents a financial responsibility of between $\$ 8$ million and $\$ 12$ million)." 79 The CCR raised concerns at that time regarding the inability of private sponsors to resettle from Turkey where many Syrians had fled ${ }^{80}$ and the additional costs resulting from reduced IFHP coverage. Restrictions on Group of Five sponsorships to recognized refugees prevents these sponsorships during mass refugee flows such as Syrian refugees where UNHCR cannot conduct individual status determinations. SAHs further noted the challenge of such a large sponsorship with no advance warning or consultation prior to the media announcement. ${ }^{81}$ Within a few months of the announcement, the CCR added, "Given the delays and barriers in the private sponsorship program, it is not expected that many privately sponsored Syrian refugees will arrive by end of 2014." 82

By October 2013, UNHCR issued a call for countries to admit up to 30,00o Syrian refugees by the end of 2014. In early 2014, the Canadian government faced questions in the House of Commons and from media on Canada's resettlement process for Syrians, compared to the commitments of other countries. Immigration Minister Chris Alexander responded by asking that "all members of the House reach out to private sponsors and sponsorship agreement holders across this country to make sure that we fill the 1,300 places available." ${ }^{83}$ Later his press secretary reiterated, "Hundreds of private sponsorship opportunities remain. We encourage sponsorship agreement holders to do their part to help displaced Syrians as well." ${ }^{84}$ The government message made it clear that the finger was pointed at private sponsors. When UNHCR requested that countries resettle more Syrian refugees, asking states to take 100,000 Syrian refugees in 2015 and 2016, the Canadian Immigrant Settlement Sector Alliance urged Canada to commit to 10,000 refugees by $2016 .{ }^{85}$ In response, Minister Alexander talked about how much
(C) Author(s), 2016. This open-access work is licensed under a Creative Commons Attribution-NonCommercial 4.0 International license.
Cette oeuvre en libre accès fait l'object d'une licence Creative Commons Attribution-NonCommercial 4.0 International. 
more can been done if the GAR program is combined with "innovative forms of private sponsorship." ${ }^{86}$ Sponsorship was clearly and unapologetically front and centre in the government's approach to Syria.

At the same time SAHs, willing to sponsor despite the lack of notice and increased expenses, were sharing with media their frustrations with sponsorship processing and delays. SAHs indicated that privately sponsored Syrians would not arrive in Canada for two to three years ${ }^{87}$ and complained of the "difficulty and costs associated with the process." ${ }^{8}$ In May 2014, the Syrian Canadian Council asserted that none of 1,300 refugees had made it to Canada and that "private sponsorship is almost impossible." ${ }^{89}$ Processing times for private sponsorship applications in Syria's neighbouring countries ranged from 24 months in Beirut to 43 months in Cairo as of July $2014.9^{\circ}$ By the end of June 2014 it was reported that the government was expediting applications for Syrian refugees. ${ }^{91}$

In January 2015, the government announced an additional 10,00o Syrian refugees would be resettled to Canada over the next three years..$^{2}$ In the same announcement, the minister of immigration indicated that since July 2013 more than 1,285 Syrian refugees had been approved for resettlement in Canada and more than 1,075 of those had already arrived by 5 January 2015. These numbers were below the 1,300 promise, even with the government going above their own commitment of 200 and approving the resettlement of 360 Syrians. Private sponsorship numbers were therefore quite high, and significantly above government numbers, but not maximized. Once again, with the announcement of the intended resettlement of 10,000 Syrians over the next three years, the majority of this promise, 60 per cent, was allocated to private sponsorship. Once again, this allocation was made without consulting sponsors. 93

The difficulty with this messaging is that it absolves the government of responsibility for either action or failure. If the numbers are met and the refugees arrive, it is the result of private efforts and not an engaged government response. If the numbers are not met and the refugees do not arrive, blame lands on private sponsors. It has been said that sponsorship is the "political barometer" of refugee support in Canada. 94 The government itself has acknowledged that "the willingness of so many Canadians to give so generously of their time to assist refugees is a visible demonstration of their commitment to continuing Canada's humanitarian tradition."95 A failure to meet the promised numbers therefore leads not only to fewer refugees receiving protection but to a powerful suggestion that resettlement is neither demanded nor supported by Canadian citizens.

And yet the numbers and financial contributions of Canadians tell a different story. Since 1979, private Canadian sponsors have resettled over 225,000 refugees. Canadian private citizens have resettled more refugees than most governments, ranking fourth behind the United States, Canada and Australia. ${ }^{96}$ In 2006, CCR assessed the annual financial costs of private sponsorship at $\$ 79$ million, with an additional volunteer contribution of over 1,600 hours per refugee family. 97 A "Sponsorship Cost Table" prepared by CIC in 2014 estimates the cost of sponsoring a single individual at $\$ 12,600 .^{98}$

The history of private sponsorship in Canada is a proud one. In 1986, UNHCR awarded the people of Canada the Nansen Medal for their resettlement of the Indochinese. 99 While recipients have included private citizens, politicians, royalty, and organizations, the award to the Canadian people is the only instance where the entire population of a country was recognized. In 2012 Australia initiated a private sponsorship program, the Community Proposal Pilot, ${ }^{100}$ after several years of community advocacy, pointing to the Canadian program as a model. ${ }^{101}$ During the 2013 emergency session in the House of Commons on the crisis in Syria, Paul Dewar reminded members of Parliament of the actions of private sponsors, including his mother, then mayor of Ottawa Marion Dewar, during the Indochinese conflict: "They said we must do more. They held local meetings where people-church groups, bowling teams and others-sponsored refugees, to help those people who were on the high seas and who were being left behind ... It was a grassroots movement that said that as Canadians we have something to do ... We went from having a quota of 8,000 refugees for that year. Because of grass roots and because Canadians mobilized and said we could do something about this, it changed to $60,000 . " 102$ There is a powerful, convincing, and inspiring pull to the power of private sponsorship and the legacy of the Indochinese resettlement.

Minister of Immigration Chris Alexander wanted Canada's Syrian response to be "one of our large, national efforts in response to a serious crisis on par with our response to the Iraqi crisis, the Vietnamese boat people, Idi Amin in Uganda in 1972 and the 1956 crackdown in Hungary."103 Responses to the crises in Uganda and Hungary predate the sponsorship program and constitute part of the rationale to introduce the regulations. The Indochinese response cemented the program into the Canadian psyche. But the Indochinese resettlement also weaved through two federal elections in Canada and three changes of the political party in power. The minority Liberal government of Pierre Trudeau made the original pledge in 1979 to accept 5,000 refugees. Following a change in government in May 1979, the minority Conservative government led by Joe Clark increased the number to 8,000 and made the later promise of 50,000 through a government-sponsor matching formula
(C) Author(s), 2016. This open-access work is licensed under a Creative Commons Attribution-NonCommercial 4.0 International license.
Cette oeuvre en libre accès fait l'object d'une licence Creative Commons Attribution-NonCommercial 4.0 International. 
by the end of $1980^{104}$ While sponsorship soared, the government struggled and ultimately opted to maintain the 50,000 resettlement figure by shifting government-assisted refugee spots to privately sponsored refugees. At the time of the government's decision, on 5 December 1979, private sponsorship was at 26,196 refugees, already exceeding its 25,000 portion, whereas the government had resettled only approximately 12,000 refugees. This left a further 11,800 refugees to be resettled, now by private citizens. ${ }^{105}$ In April 1980, the majority Liberal government of Pierre Trudeau re-assumed power. As the new immigration minister, Lloyd Axworthy announced the government's renewed commitment to the Indochinese and increased resettlement targets to 60,000 on 2 April $1980 .{ }^{106}$ The 60,000 target unofficially rebalanced the matching formula between sponsorship and government resettlement. The announcement and swift changes mark the line between politics and law and the role each plays. Shortly after, Gerald Dirks observed, "Any contentiousness associated with refugee admission to Canada in recent years has not arisen due to inadequacies in the legislation but rather has resulted from policy preferences and day-to-day administrative procedures determined by the cabinet and officials of the Employment and Immigration Commission." 107 The law was broad and the policy malleable.

Canada's resettlement of Syrian refugees likewise experienced a change of government in the midst of the initiative. Almost a decade of Conservative leadership ended with the election of the majority Liberal government led by Justin Trudeau on 19 October 2015. Resettlement was a key election issue in 2015, receiving far more prominence than during the elections that spanned the Indochinese crisis, or in the nine federal elections and other refugee crises in between. ${ }^{108}$ During the campaign, Justin Trudeau pledged to bring in 25,000 government-assisted Syrian refugees to Canada by the end of 2015, significantly exceeding competing party promises. ${ }^{109}$ By the end of November, the new government revised its election promise and committed to bringing in 10,000 Syrian refugees by the end of 2015, with the remainder arriving by February 2016. ${ }^{110}$ The initial Liberal election promise stood out on its recommitment to GARs, making government promises for government resettlement instead of promises for private sponsors. By November, with the realities of screening and processing refugees setting in, the revised plan relied heavily on private sponsors: "The government also has several thousand applications in processing for privately sponsored refugees (PSRS) under way, and these will be included as part of the commitment."111 At the close of 2015, Minister McCallum announced that just over 6,000 Syrians, mostly privately sponsored Syrians, had arrived in Canada. ${ }^{12}$ While sponsored refugees

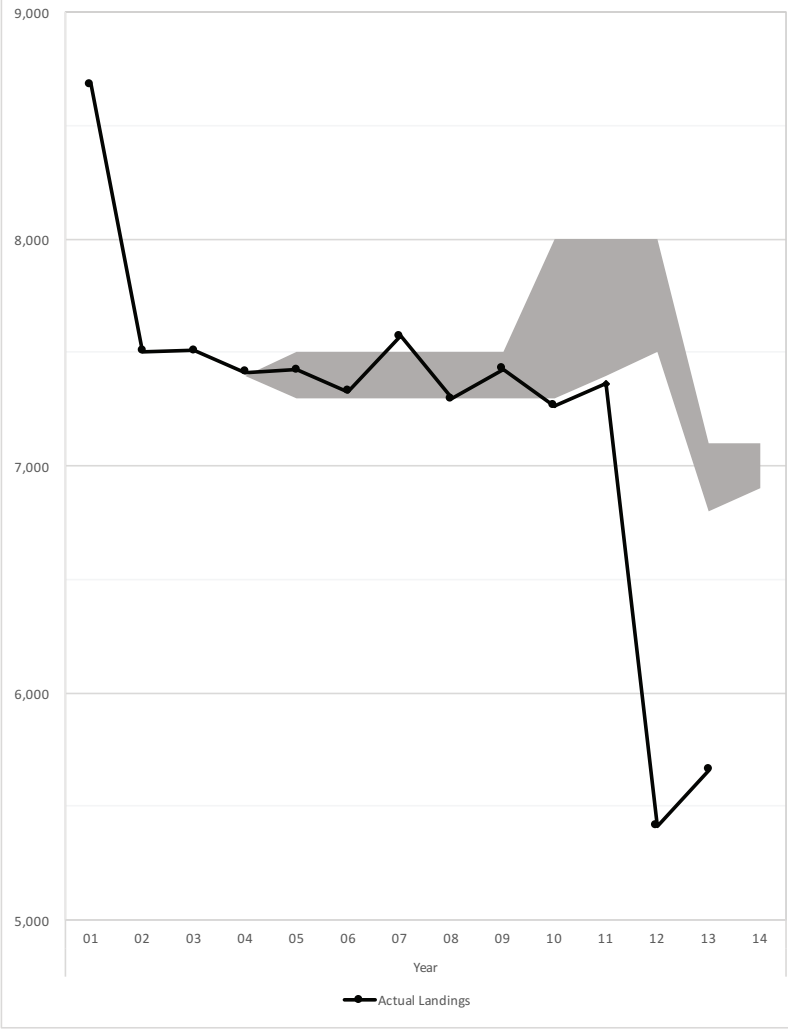

Figure 2. Government-assisted refugees ranges and landings, 2001-2014

will facilitate the February 2016 timeline, the government remains, at the time of writing, committed to 25,000 Syrian GARS in 2016: "The government's commitment to bringing in Syrian refugees will continue in 2016. Given the current initiative includes privately sponsored refugees, this will include taking in more government-assisted refugees (GARs) to reach a total target of 25,000 GARs." 113 What this means for future Canadian resettlement numbers, both GAR and PSR, is difficult to predict.

The previous government's 2010 promise of a 20 per cent increase to resettlement was never met. In 2009 total resettlement numbers sat at 12,461 , while in 2015 the target range was $11,900-15,200 .{ }^{114}$ At the low end, this is no increase at all. At the high end it just passes the 20 per cent increase, but this number includes 1,000 BVOR, a massive leap from the currently released numbers. The BVOR targets may now be reached or surpassed as the crisis in Syria has sparked an unprecedented interest in resettlement and private sponsorship reminiscent of the uprising of sponsorship support during the Indochinese crisis of the 1970s. ${ }^{115}$ Syrian resettlement by both the government and private sponsors will significantly raise overall resettlement. It is questionable, though, whether this level of interest and support will continue as sustainable sponsorship support or a singular 


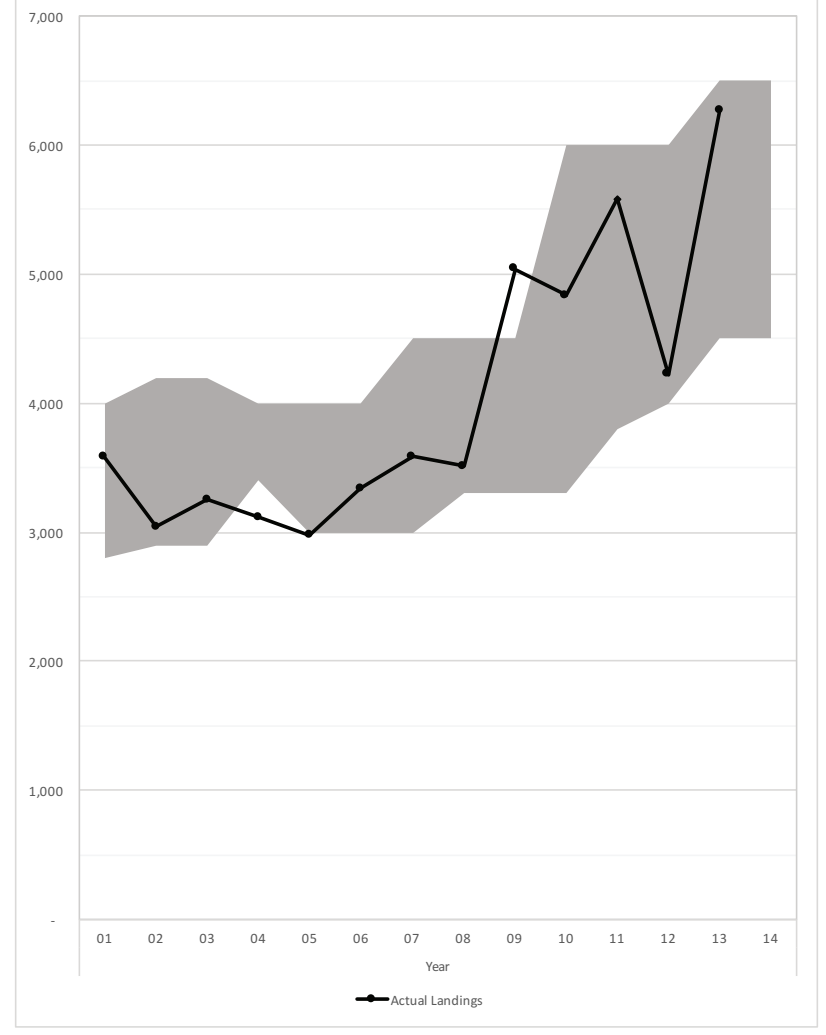

Figure 3. Privately sponsored refugees ranges and landings, 2001-2014

response to a particular moment. Nor, as figures 2 and 3 illustrate, have numbers regularly come close to the upper threshold allowances in the last decade.

There have been reassurances that the Syrian effort will be over and above yearly resettlement targets and recognition that the immense tragedy of the Syrian people cannot overshadow the plight of other refugees in need of protection and resettlement. UNHCR now estimates there are $1,150,300$ refugees in need of resettlement. This is a 50 per cent increase in need from 2012, and projections continue to increase. ${ }^{116}$ Canada's moment of generosity on the Syrian front is a mere drop in the bucket. How Canada will set new targets and balance private and government responsibilities remains to be seen. The Liberal government has indicated that it intends to reverse many of the constraints put on sponsors by the previous government. The mandate letter to the new minister of immigration, refugees and citizenship, John McCallum, includes directions to return the maximum age for dependent children from 19 to 22 , reduce visa application processing times, and fully restore the Interim Federal Health Program. ${ }^{117}$ Whether caps on sponsorship submissions, the limitations on Group of Five and Community Sponsorships, or the shifting focus of the BVoR program continue are unknown.
Sponsorship arose out of a desire to do more. The past decade witnessed a period in which the program operated arguably out of a fear that to do otherwise would amount to less being done. The first comprehensive review of the private sponsorship program in the 1990s cautiously acknowledged, "It remains to be seen whether the resource is renewable, like forests, or whether it more closely resembles gold and, once again mined, is depleted."118 Past policies and numeric shifts suggest a government assumption that sponsorship capacity is unlimited. Sponsors, despite hesitations, complaints, and a frustration at the lack of consultation, continue submitting applications that reaffirm the myth of renewability, even in moments of crisis. If the Syrian crisis brings in new sponsors and resets government-sponsor relations, it is a moment for both sides to assess their role in the program. This piece is not prescriptive, nor are sponsors a single-minded community, but historical understanding and contextual knowledge are necessary to address how to move forward, to reassert additionality, and to maintain incentives for sustainable sponsorship.

\section{Acknowledgments}

This paper benefitted from the exceptional research assistance of Nora Fien and was supported by the University Research Grant Program at the University of Manitoba.

\section{Notes}

1 For a discussion of the general challenge of operating a resettlement program alongside the obligation of asylum, see Shauna Labman, "Queue the Rhetoric: Refugees, Resettlement and Reform," University of New Brunswick Law Journal 62 (2011): 55-63.

2 David Corbett, Canada's Immigration Policy: A Critique (Toronto: University of Toronto Press, 1957), 198-9.

3 Sharryn J. Aiken, "Of Gods and Monsters: National Security and Canadian Refugee Policy," Revue québécoise de droit international 14, no. 2 (2001): 9.

4 Gerald E. Dirks, "A Policy within a Policy: The Identification and Admission of Refugees to Canada," Canadian Journal of Political Science 17, no. 2 (1984): 280; Alan G. Green and David Green, "The Goals of Canada's Immigration Policy: A Historical Perspective," Canadian Journal of Urban Research 13, no. 1 (2004): 102.

5 See Aiken, "Of Gods and Monsters," 9; James C. Hathaway, "Selective Concern: An Overview of Refugee Law in Canada," McGill Law Journal 33, no. 4 (1987-8): 677-8.

6 Howard Adelman, Canada and the Indochinese Refugees (Regina: L. A. Weigl Educational Associates, 1982), 107. An Order in Council, 2 June 1922, permitted Mennonites from the Soviet Union to come to Canada but required that the Canadian Mennonite community take responsibility for the care of the newcomers so that they would 
not become a burden on the state. William Janzen, "The 1979 MCC Canada Master Agreement for the Sponsorship of Refugees in Historical Perspective," Journal of Mennonite Studies 24 (2006): 212.

7 Freda Hawkins, Canada and Immigration: Public Policy and Public Concern (Montreal and Kingston: McGillQueen's University Press, 1972), 304-5.

8 In 1957 Canada became a member of the United Nations Refugee Fund Executive Committee. The Executive Committee of the High Commissioner's Programme was established in 1958 by the Economic and Social Council (ECOSOC) Resolution E/REs/672 (xxv) (30 April 1958), and Canada continued on as a member. UNHCR, "Excom Membership by Date of Admission of Members" (30 June 2009).

9 Laura Madokoro, “Belated Signing': Race-Thinking and Canada's Approach to the 1951 Convention relating to the Status of Refugees" (forthcoming).

10 UNHCR, "States Parties to the Convention relating to the Status of Refugees and the 1967 Protocol," http://www. unhcr.org/protect/PROTECTION/3b73bod63.pdf. Earlier, the 1966 White Paper on Immigration recommended that Canada accede to the 1951 Convention and introduce separate legislation to "help refugees." Department of Manpower and Immigration, White Paper on Immigration (Ottawa: 1966), 54-5.

11 Canada continued to see itself as operating a refugee program directed primarily at resettlement, until the 1990 Annual Report to Parliament on Future Immigration Levels, which acknowledged that it "has become a country of first asylum for thousands of people." Employment and Immigration Canada, Annual Report to Parliament: Immigration Plan for 1991-1995 (Ottawa: EIC, 1990), 5.

12 Office of the Minister of Manpower and Immigration, "Statement by the Honourable Robert Andras, Minister of Manpower and Immigration," 17 Septemeber 1973. Prior to this announcement, a rudimentary system for dealing with resettlement and refugee claims in Canada was implemented through Cabinet documents 27 July 1970 and 16 September 1970 and Operations Memorandum 17 January 1971, amended 19 June 1972. This scheme shaped Canada's response to the Indochinese refugees from May 1975 to December 1978. With thanks to Mike Molloy, former director of Refugee Policy Division, for this point.

13 Joseph Kage, "Stepping Stones towards the New Canadian Immigration Act," Jewish Immigrant Aid Society Information Bulletin no. 347 (20 November 1973), 12.

14 Joseph Kage, "Re-Appraising the Canadian Immigration Policy: An Analysis and Comments on the White Paper on Immigration" (January 1967), 18, Canadian Jewish Congress Charities Committee National Archives.

15 Immigration Act, SC 1976-77, C 52.

16 Barbara Treviranus and Micheal Casasola, "Canada's Private Sponsorship of Refugees Program: A Practitioner's Perspective of Its Past and Future," Journal of International
Migration \& Integration 4 (2003): 184; Janzen, "1979 MCC Canada Master Agreement," 212.

17 Citizenship and Immigration Canada (hereafter CIC), "Private Sponsorship of Refugees Program: Sponsorship Agreement Holders," http://www.cic.gc.ca/english/refugees/sponsor/list-sponsors.asp.

18 The MCC was the first national church body to sign a Master Agreement. Janzen, "1979 MCC Canada Master Agreement," 211.

19 Howard Adelman, "The Policy Maker and the Advocate: Case Studies in Refugee Policy," in Making Knowledge Count: Advocacy and Social Science, ed. Peter HarriesJones (Montreal and Kingston: McGill-Queen's University Press, 1991), 62.

20 Employment and Immigration Canada, Indochinese Refugees: The Canadian Response, 1979 and 1980 (Ottawa: Minister of Supply and Services Canada, 1982), 18.

21 Ibid., 8.

22 Employment and Immigration Canada, "Private Sponsorship of Refugee Program," Refuge 12 (1992): 3.

23 Thomas R. Denton, "Understanding Private Refugee Sponsorship in Manitoba," Journal of International Migration \& Integration 4 (2003): 264.

24 The cancellation of the Assisted Relative category occurred through the repeal of the Immigration Regulations, 1978, SOR/78-172, by the Immigration and Refugee Protection Regulations, sOR/2002-227, s 364(a) that accompanied the introduction of the Immigration and Refugee Protection Act. In a 2004 resolution the Canadian Council for Refugees notes, "Cancellation of the Assisted Relative category has greatly increased the pressure on the Private Sponsorship program." Canadian Council for Refugees, "Assisted Relatives: Resolution number 2" (November 2004), www. ccrweb.ca/en/res/assisted-relatives.

25 Immigration and Refugee Protection Act, sC 2001, c 27, s 12(1); Immigration and Refugee Protection Regulations, $s$ $117(1)$.

26 Immigration Regulations, s 2(1).

27 Denton, "Understanding Private Refugee Sponsorship," 258.

28 CIC, Summative Evaluation of the Private Sponsorship of Refugees Program (2007), 4.0.

29 Ibid., 1.2.1.

30 CIC, A Broader Vision: Immigration Plan (1996 Annual Report to Parliament), (Ottawa: Minister of Supply and Services Canada, 1995), 14.

31 CIC, "Government of Canada and the Anglican Church of Canada Encourage Canadians to Sponsor Refugees," news release, 16 April 2009; CIC, "Canada and Anglican Church Give 50 Refugee Families New Hope,” news release, 13 February 2012.

32 CIC, "Government of Canada to Help Gay and Lesbian Refugees Fleeing Persecution,” news release, 24 March 2011.
(C) Author(s), 2016. This open-access work is licensed under a Creative Commons Attribution-NonCommercial 4.0 International license.
Cette oeuvre en libre accès fait l'object d'une licence Creative Commons Attribution-NonCommercial 4.0 International. 
33 "Rainbow Refugee Assistance Program Extended for 2 Years," свс News, 10 March 2015.

34 Immigration and Refugee Protection Regulations, s 157; CIC, Guide to the Private Sponsorship of Refugees Program (Ottawa: Minister of Public Works and Government Services Canada, 2011), 25.

35 CIC, "Regulations Amending the Immigration and Refugee Protection Regulations and Regulatory Impact Analysis Statement," soR/2012-225, 146:23 Canada Gazette (9 June 2012).

36 CIC, "Notice Requesting Comments on a Proposed Regulatory Amendment That Will Affect the Private Sponsorship of Refugees Program," 145:50 Canada Gazette (10 December 2011); Immigration and Refugee Protection Regulations, s 153(1)(b).

37 CIC, "Regulations Amending the Immigration and Refugee Protection Regulations and Regulatory Impact Analysis Statement," 145:2 Canada Gazette (19 March 2011).

38 CIC, "Regulations Amending the Immigration and Refugee Protection Regulations and Regulatory Impact Analysis Statement," 147:20 Canada Gazette (18 May 2013); CIC, "Regulations Amending the Immigration and Refugee Protection" 148:13 Canada Gazette (18 June 2014).

39 Order Respecting the Interim Federal Health Program, 2012, SI/2012-26 (5 April 2012), 146:9 Canada Gazette (25 April 2012); Order Amending the Order Respecting the Interim Federal Health Program, 2012, SI/2012-49 (28 June 2012) 146:15 Canada Gazette (18 July 2012), replaced the 1957 OIC, effective 30 June 2012.

40 Canadian Doctors for Refugee Care v Canada (AG), 2014 FC 65 para 35.

41 The original Order (si/2012-26) cut coverage for all resettlement refugees, but the amended Order (sI/201249) provided that extended coverage was to be granted to government-assisted refugees, while only basic coverage was to be given to privately sponsored refugees.

42 Hospitality House Refugee Ministry Inc v Canada (AG), 2013 FC 543. In November 2015, Citizenship and Immigration Canada was rebranded as Immigration, Refugees and Citizenship Canada (IRCC).

43 Ibid., para 7.

44 Laura Payton, "Federal Government to Appeal Ruling Reversing 'Cruel' Cuts to Refugee Health,” свс News, 4 July 2014.

45 A request to stay Mactavish's order pending the appeal was denied by Justice Webb on 31 October 2014. Canada (AG) $v$ Canadian Doctors for Refugee Care 2014 FCA 252.

46 CIC, "Temporary Measures for the Interim Federal Health Program" (4 November 2014).

47 Canadian Doctors for Refugee Care v Canada (AG) 2015 FC 149. As discussed below, following the 2015 federal election, the Liberal government announced intentions to fully restore the Interim Federal Health Program. See note 117
48 CIC, Annual Report to Parliament on Immigration, 2009 (Ottawa: CIC, 2009).

49 CIC, "Expanding Canada's Refugee Resettlement Programs," news release, 29 March 2010. Bill C-11, Balanced Refugee Reform Act, was introduced the following day: Hansard: House of Commons Debates, 4oth Parl, 3rd Sess, No 20 (30 March 2010), 1005 (Hon. Jason Kenney, Minister of Citizenship, Immigration and Multiculturalism).

50 Government of Canada, 2012 Federal Budget (29 March 2012) shows the planned reduction in Citizenship and Immigration Canada spending in table 5.1 resulting from this shift.

51 CIC, "Canada to Resettle 1300 Syrian Refugees by End of 2014," news release, 3 July 2013.

52 Ibid.

53 UNHCR, "Finding Solutions for Syrian Refugees: Resettlement and Other Forms of Admission of Syrian Refugees" (11 August 2014).

54 CIC, Annual Report to Parliament on Immigration 2013 (Ottawa: CIC, 2013), 17.

55 CIC, Annual Report to Parliament on Immigration 2014 (Ottawa: CIC, 2014). The 12,00o total includes the GAR and PSR numbers set out below $(11,930)$ as well as 153 Visa Office Referred refugees set out in the 2014 annual report and discussed below.

56 Sandra Elgersma, "Resettling Refugees: Canada's Humanitarian Commitments," pub. no. 2015-11-E (Ottawa: Library of Parliament Research Publications, 2015).

57 Canadian Council for Refugees, "Important Changes in Canada's Private Sponsorship of Refugees Program" (January 2013).

58 CIC, "Blended Visa Office-Referred Program: Sponsoring Refugees" (30 April 2014).

59 Mennonite Central Committee, "Blended vor Initiative: 2014 Update" (2014); cIC, Guide to the Private Sponsorship, 11.

$60 \mathrm{CIC}$, Information Sheet for Interim Federal Health Program Beneficiaries (14 February 2014), 2.

61 CIC, "Blended Visa Office-Referred Program."

62 CIC, "Government of Canada's Immigration Planning Story: Operational Targets by Office (Non-Economic)" (16 April 2014).

63 CIC, Annual Report 2014: Facts \& Figures 2014.

64 CIC, "Blended Visa Office-Referred Program."

65 CIC, "Operational Bulletin 512 (Modified) - February 12, 2014" (12 February 2014). CIC, "Supplementary Information 2015"; CIC, "Departmental Performance Report (for the Period Ending March 31, 2012)" (30 May 2013).

66 CIC, "How to Sponsor a Refugee: Blended Visa OfficeReferred Program," video (28 April 2014), http://www.cic. gc.ca/english/department/media/multimedia/video/vor/ vor.asp.

67 Treviranus and Casasola, "Canada's Private Sponsorship of Refugees Program," 178; UNHCR, Resettlement Handbook (November 2004), 220. 
68 Hathaway, "Selective Concern," 700.

69 Catherine Dauvergne, Humanitarianism, Identity, and Nation: Migration Laws of Australia and Canada (Vancouver: UвC Press, 2005), 93.

70 Adelman, Canada and the Indochinese Refugees, 85.

71 Adelman, "The Policy Maker," 62; Howard Adelman, "Changes in Policy: Background on the Federal Government Decision to Alter Its Position with Respect to the Indochinese Refugees," in The Indochinese Refugee Movement: The Canadian Experience, ed. Howard Adelman (Toronto: Operation Lifeline, 1979), 23.

72 Ibid.; Adelman, "Changes in Policy," 25. Formed in 1978, the Standing Conference of Organizations Concerned for Refugees was the original name of the Canadian Council for Refugees.

73 Employment and Immigration Canada, "Sponsoring Refugees: Facts for Canadian Groups and Organizations" (July 1979), 2, http://cihs-shic.ca/wp-content/uploads/2015/o3/ Sponsoring-Refugees-Facts-for-Canadian-Groups-andOrganizations.pdf.

74 CIC, Guide to the Private Sponsorship, 11. See also CIC, Report on Plans and Priorities 2014-2015, 2.2.2.

75 Canadian Council for Refugees, "Important Changes."

76 "Global Consultations on International Protection, Strengthening and Expanding Resettlement Today: Challenges and Opportunities," 4th Mtg., EC/GC/02/7 (25 April 2002), para 5.

77 House of Commons Debates, 41st Parl, 1st Sess, No 248 (7 May 2013), 1840.

78 CIC, "Canada to Resettle 1,30o Syrian Refugees."

79 Canadian Council for Refugees, "CCR Responds to Government Announcement on Resettlement of Syrian Refugees" (8 July 2013).

80 Sponsorship from Turkey is now possible. CIC initiated a pilot project in 2014, extended through 2015, for sponsorship from Turkey. Refugee Sponsorship Training Program, "Guidelines on Sponsorship of Refugees out of Turkey," http://www.rstp.ca/en/refugee-sponsorship/ latest-policy-program-update/guidelines-turkey/.

81 Ashley Chapman, "Time for Canada to Step Up on Syrian Refugee Crisis, Now," Hill Times, 16 June 2014; Michael Swan, "Syrian Refugee Flow to Canada at a Trickle," Catholic Register, 26 June 2014.

82 Canadian Council for Refugees, "Canadian Immigration Responses to the Syrian Crisis: Backgrounder" (October 2013).

83 House of Commons Debates, (27 February 2014), 1500.

84 Alexis Pavlich, quoted in Debra Black, "Slow Progress Raises Doubts about Government's Syrian Refugee Pledge," Toronto Star, 18 March 2014.

85 Susana Mas, "Syrian Refugees: Canada Urged to Take In 10,000 by 2016," СBC News, 19 June 2014; Canadian Immigrant Settlement Sector Alliance, "CISSA-ACSEI Appeal to Minister Alexander" (4 June 2014).

86 Mas, "Syrian Refugees."
87 Xueting Zhao, "Syrian Refugees Waiting for Canada to Open the Door," Toronto Observer, 27 February 2014.

88 Michelle Zilio, "Canada Has Only Settled 'a Few' Government-Sponsored Syrian Refugees: Alexander," iPolitics, 5 March 2014.

89 Lina Dib, "Un Asks Ottawa to Open Its Doors for Refugees of Syria's Brutal Civil War," Canadian Press, 29 May 2014. In June 2014, both the director of the Syrian Canadian Council of Montreal and the sponsorship director of the Anglican United Refugee Alliance indicated that they had not heard of any of the 1,100 private sponsorship allotment actually arriving in Canada: "Syria's Refugees: Is Canada Keeping Its Promise? A Timeline of As It Happens Coverage," СвC, 26 June 2014 (June 12 audio), http://www.cbc.ca/radio/asithappens/thursdaysupreme-court-of-canada-first-nations-ruling-cbcstrategy-seasick-shark-fisherman-and-more-1.2903421/ syria-s-refugees-is-canada-keeping-its-promise-a-timeline-of-as-it-happens-coverage-1.2903424/.

90 CIC, "Processing Times for Privately Sponsored Refugee Applications" (22 July 2014).

91 Laura Lynch, "Syrian Refugee Applications Quietly Sped Up by Ottawa," свс News, 27 June 2014.

92 Foreign Affairs, Trade and Development Canada, "Helping to Protect the World's Most Vulnerable," news release, 7 January 2015.

93 Loly Rico, president, Canadian Council for Refugees, to Chris Alexander, minister of citizenship and immigration, "Letter concerning Resettlement of Syrian Refugees," 14 January 2015.

94 Gertrude Neuwirth and J. R. Rogge, "Canada and the Indochinese Refugees," in Indochinese Refugees: Asylum and Resettlement, ed. Supang Chantavanich and E. Bruce Reynolds (Bangkok: Institute of Asian Studies, Chulalongkorn University, 1988), 254.

95 Employment and Immigration Canada, "Private Sponsorship," 3 .

96 Treviranus and Casasola, "Canada's Private Sponsorship of Refugees Program," 18o.

97 Canadian Council for Refugees, "The Private Sponsorship of Refugees Program: Current Challenges and Opportunities" (April 2006), 2.

98 Refugee Sponsorship Training Program, "Fact Sheet: Sponsorship Cost Table," March 2014, http://www.rstp.ca/ wp-content/uploads/2014/03/Fact_Sheet_7_3_Sponsorship_Cost_Table_Sept2014.pdf.

99 UNHCR, "Nansen Refugee Award," http://www.unhcr.org/ nansen/503625396.html.

100 Australia, Commonwealth, Department of Immigration and Citizenship, "Australia's Humanitarian Program 201314 and Beyond," information paper (December 2012), 5.

101 Refugee Council of Australia, "Australia's Refugee and Humanitarian Program 2010-11: Community Views on Current Challenges and Future Directions" (February 2010), 3 .
(C) Author(s), 2016. This open-access work is licensed under a Creative Commons Attribution-NonCommercial 4.0 International license.
Cette oeuvre en libre accès fait l'object d'une licence Creative Commons Attribution-NonCommercial 4.0 International. 
102 House of Commons Debates, 41st Parl, 1st Sess, No 248 (7 May 2013) 2000.

103 Steven Chase, "Canada to Boost Efforts to Help Syrian Refugees," Globe and Mail, 4 July 2014.

104 Ninette Kelley and Michael J. Trebilcock, The Making of the Mosaic: A History of Canadian Immigration Policy (Toronto: University of Toronto Press, 1998), 407.

105 “Onus Put on Public Groups, Ottawa Won't Sponsor More Refugees," Globe and Mail, 6 December 1979; Adelman, "Changes in Policy," 23.

106 "Ottawa Revamps Refugee Program, Increases 1980 Quota by 10,0oo," Globe and Mail, 3 April 1980.

107 Dirks, "Policy within a Policy," 299.

108 See, for example, Laura Payton, "Election Issues 2015: A Maclean's Primer on Syrian Refugees," Maclean's, 3 September 2015; "Stephen Harper Suggests Canada Will Do More to Help Syrian Refugees," СвC News, 10 September 2015; Andy Blatchford, "Canada Election 2015: Syrian Refugee Crisis Re-emerges on Campaign Trail,” Huffington Post Canada, 8 September 2015; "Election Primer: The Refugee Crisis, Four Things to Know before You Vote," Globe and Mail, 16 October 2015.

109 Liberal Party, "Syrian Refugees," https://www.liberal.ca/ realchange/syrian-refugees. The party platform did not attach a deadline to the commitment but the timeline was clearly put forward during the campaign. The New Democratic Party promised to bring 10,000 Syrian refugees to Canada by year end, and the Conservative Party promised to resettle 10,00o Syrians by 2017.

110 Government of Canada, "Canada Offers Leadership on the Syrian Refugee Crisis," news release, 24 November 2015.

111 Ibid.

112 Joe Friesen, "Liberals Fall Short of Year-End Goal for Refugee Resettlement," Globe and Mail, 31 December 2015.
113 Government of Canada, "Canada Offers Leadership on the Syrian Refugee Crisis."

114 CIC, "Supplementary Information to the 2015 Immigration Levels Plan."

115 Ratna Omidvar, "Private Sponsors Build a Nation-and Leave a Legacy," Globe and Mail, 16 November 2015; Caroline Barghout, "Image of Alan Kurdi Dead on a Beach Moves Winnipeg Woman to Help Syrian Refugees," СвС News, 25 November 2015.

116 UNHCR, UNHCR Refugee Resettlement Trends 2015 (June 2015), 7.

117 Prime Minister of Canada, "Minister of Immigration, Refugees and Citizenship Mandate Letter," http://pm.gc. $\mathrm{ca} / \mathrm{eng} / \mathrm{minister-immigration-refugees-and-citizenship-}$ mandate-letter. On 16 December 2015 the Government of Canada announced that it would not pursue its appeal on the Interim Federal Health Program case and formally confirmed that all Syrian refugees, government and privately sponsored, were eligible for supplementary health coverage. Statement from the minister of immigration, refugees and citizenship, and the minister of justice and attorney general of Canada, Ottawa (16 December 2015); Government of Canada, "Interim Federal Health Program Coverage for Syrian Refugees," backgrounder, 16 December 2015.

118 Employment and Immigration Canada, Annual Report to Parliament: Immigration Plan for 1991-1995 Year Two (Ottawa: EIC, 1991), 22.

Shauna Labman is an assistant professor in the Faculty of Law at the University of Manitoba. She may be contacted at shauna.labman@umanitoba.ca. 


\title{
The Indochinese Refugee Movement: An Exploratory Case Study of the Windsor Experience
}

\author{
GIOVANA ROMA
}

\begin{abstract}
Following the fall of Saigon in 1975, thousands fled Indochina in small boats to attain political asylum in neighbouring countries. Canada played a leading role in the resettlement of thousands of Indochinese refugees, and a significant part of this national effort was led by the city of Windsor, Ontario. This article examines Windsor's local efforts to sponsor and integrate Indochinese refugees into Canadian society. In late 1977, Windsor Mayor Bert Weeks established an ad hoc committee on Indochinese refugees. Together with volunteers from local faith communities and non-governmental organizations, the city created a vast resettlement network and assumed the sponsorship of several families, well before the wave of refugees arrived in 1979. As an exploratory work, this article provides evidence of Windsor's pivotal role in shaping the Canadian response to the Indochinese refugee crisis and may challenge the national narrative that large Canadian cities led refugee resettlement efforts. This study is timely, as important lessons can be drawn from the Windsor experience.
\end{abstract}

\section{Résumé}

À la suite de la chute de Saigon en 1975, des milliers de réfugiés ont fui l'Indochine dans des petites embarcations en quête d'asile politique dans les pays voisins. Le Canada a joué un rôle de premier plan dans la réinstallation de milliers de réfugiés indochinois, et une partie importante de cette initiative nationale était menée par la municipalité de Windsor, en Ontario. Cet article examine les initiatives locales de la part de Windsor en matière de parrainage et intégration des réfugiés indochinois à la société canadienne. Vers la fin de l'année 1977, Bert Weeks, maire de Windsor, avait établi un comité spécial pour les réfugiés indochinois. En collaboration avec des volontaires issus de communautés religieuses locales et des organismes non gouvernementaux, la municipalité avait créé un vaste réseau dédié à la réinstallation et entrepris le parrainage de plusieurs familles, bien avant l'influx des réfugiés en 1979. En tant que recherche exploratoire, cet article fournit des preuves du rôle déterminant de la municipalité de Windsor dans la formulation de la réaction canadienne à la crise des réfugiés indochinois, et pourrait mettre en question le discours national selon lequel le rôle principal pour les initiatives de réinstallation des réfugiés revenait aux grandes métropoles canadiennes. Cette étude est donc pertinente, étant donné qu'il y a des leçons importantes que l'on pourrait tirer de l'expérience de Windsor.

\section{Introduction}

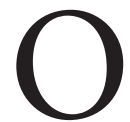
n 30 April 1975, the South Vietnam capital of Saigon was captured by Communist forces, marking the end of the Vietnam War. Cambodia and Laos quickly followed suit, and soon after, all of Indochina was ruled by Communist regimes. ${ }^{1}$ It was the beginning of a new, capricious regional order, which sparked a mass exodus of refugees. Approximately 135,000 Vietnamese fled the country before Saigon collapsed, sparking a humanitarian crisis of global proportions. 
Over 2 million people fled the Indochinese countries of Vietnam, Laos, and Cambodia over the next decade, and approximately 20 million were displaced at one point or another. ${ }^{2}$ Thousands fled in small boats, crossing pirateridden waters in hopes of finding safety in neighbouring countries. In this context, Canada played a leading role in the resettlement of thousands of Indochinese refugees, accepting an estimated 60,00o between 1979 and 1980, and anywhere from 130,000 to 150,000 refugees in total. ${ }^{3}$ At the forefront of this national initiative is the small city of Windsor, Ontario.

In late 1977, Windsor Mayor Bert Weeks established an "ad-hoc committee on Indochinese refugees." Together with volunteers from the local faith communities and non-governmental organizations, the City of Windsor created a vast refugee network and assumed the sponsorship of several families, well before the "flood of refugees" arrived in 1979. This article examines Windsor's local efforts to sponsor and integrate Indochinese refugees into Canadian society and provides evidence that Windsor may have served as a model to other Canadian resettlement efforts, by leading in the resettlement of Indochinese refugees in late 1977-well before the large Canadian cities began to organize themselves in 1979.

\section{Research Methodology}

This case study focuses on the City of Windsor's Indochinese refugee resettlement efforts from 1977 to the early 1990s. Michael Molloy coordinated the Indochinese refugee movement in 1979 and 1980. As president of the Canadian Immigration Historical Society, Michael stumbled upon the Windsor story by chance, as he was digging through national archival records on the Indochinese refugee crisis. There he found a memorandum to Minister Cullen, which cited Windsor's efforts in assisting refugee families. From this, Michael recruited me-a research associate at the University of Windsor-to track down additional clues of the city's precedent-setting involvement in refugee resettlement.

This is an exploratory study, which serves as a cursory introduction to the Windsor experience. Several studies evaluate the Canadian response to the Indochinese refugee crisis. Of note are Neuwirth and Clark (1981), Adelman (1982), Lanphier (1983), Chan and Indra (1987). ${ }^{4}$ However, few have written about the experiences at the local levels. Although some sources mention Windsor in passing, no published study provides an in-depth look at the city's Indochinese resettlement model. 5 Such a study is warranted, especially given the evidence that the Windsor program was ahead of its time and received national and regional attention. As is the case with most exploratory studies, the article leaves a lot of questions unanswered. Its main aim is to unveil an untold piece of local (and national) history by exploring the City of Windsor's resettlement model and its possible reach. While the study is not meant to draw firm conclusions, it provides evidence that suggests the Windsor model was avant-garde in its response to the Indochinese movement, and challenges the national narrative that large Canadian cities led refugee resettlement efforts in the late 1970 and early 1980s. It is hoped that future research can help confirm these suggestions.

For this article, case study research of the Windsor model was conducted from November 2014 to March 2015. Primary and secondary sources were used. Primary sources include archival research and semi-structured informal interviews. First, a number of archives were consulted in order to find primary documents that illuminate the historical period under analysis, starting from 1974 (before the fall of Saigon) to the early 199os. The archival documents used in this study originate from the Windsor Community Archives at the Windsor Public Library; the Windsor Star Archives; the Edmonton Catholic Social Services; the Catholic Diocese of London; Library and Archives Canada; and personal manuscripts from interviewees. ${ }^{6}$

Next, semi-structured, informal interviews were conducted with eight individuals who were involved in the local resettlement program. Interviewees include volunteers who were directly involved with the process, those close to the leaders of resettlement efforts, and local Indochinese refugees. Interviews were conducted in English, by the author, in person and by telephone. Respondents were selected using the snowballing technique, in which interviewees were suggested by participants. Information gleaned from eight interviews is included in this study.

Secondary information-in the form of peer-reviewed journal articles, government reports, theses, and newspaper articles-provides historical context and an overview of literature on the subject. These texts were obtained through online research databases and local archives. Other individuals and organizations involved in local resettlement were also consulted, including local churches and nongovernmental organizations. ${ }^{7}$

There were several limitations to this study. Since Windsor's active role in the resettlement of Indochinese refugees occurred 40 years ago, many organizations have permanently closed, and their records have either been destroyed or lost. As the home of Father Warden, St. Joseph's Catholic Church housed most records associated with the Mayor's Ad Hoc Committee and the Windsor Friendship Families. However, this church has since been closed, and all archival records, excluding sacramental certificates, have been destroyed. Another setback in the collection of research is that several leaders involved in the Windsor project,
(C) Author(s), 2016. This open-access work is licensed under a Creative Commons Attribution-NonCommercial 4.0 International license.
Cette oeuvre en libre accès fait l'object d'une licence Creative Commons Attribution-NonCommercial 4.0 International. 
including Mayor Bert Weeks and Father Warden have passed away. In order to mitigate these gaps, interviews were conducted with individuals who knew the actors well during this time. Interviewees included Mayor Weeks's former commissioner of finance, his executive assistant, and his daughter. Primary sources, including committee minutes, ${ }^{8}$ letters of correspondence, and local newspaper articles were also used to substantiate interviews.

To commence, this article provides an explanation of the Windsor Indochinese resettlement model, which is broken down into two crucial elements: (1) the Mayor's Ad Hoc Committee on Indochinese Refugees and (2) the Friendship Families. The Windsor model is then situated in the greater historical context, in order to analyze its possible impact and offer suggestions for future research.

\section{Windsor's Indochinese Resettlement Program}

Windsor's manufacturing economy and strong unions gave the New Democratic Party a large support base. As a result, the city boasts one of the first welfare systems in the country and is the home of respected non-profit organizations including United Way and the Windsor Coalition for Development. 9 In the time leading up to the Indochinese refugee movement, Windsor had already played an important role in the resettlement of refugees from Hungary, Hong Kong, Czechoslovakia, Uganda, and Chile, establishing a basis for resettlement efforts to come. ${ }^{10}$

Between 1978 and 1993, the Windsor area resettled over 1,900 government-sponsored Indochinese refugees. ${ }^{11}$ The city's role in the resettlement of hundreds of Indochinese refugees can be divided into two, complementary developments: (1) the Mayor's Ad Hoc Committee on Indochinese Refugees and (2) the Friendship Families program.

First, the Mayor's Ad Hoc Committee on Indochinese Refugees was established in late 1977 by Mayor Bert Weeks. ${ }^{12}$ The committee operated out of the City of Windsor and included city councillors, members of the local faith communities, local and regional representatives from the Canadian government, members from the University of Windsor, and the public school boards. Key members of the committee included Frank Chauvin, a local police detective and humanitarian; Herald Bastien, immigration manager for Windsor and Essex County; Ralph Talbot, the local settlement counsellor for the Canada Employment Centre; André Pilon, settlement director for the Ontario Region at Employment and Immigration Canada (Toronto); and leaders of the faith communities, including Reverend Tom Lever and Father Robert Warden.

Windsor's resettlement efforts came at a critical time during Canada's immigration history. The mass exodus of Indochinese refugees occurred between mid-1978 and 1980, with the majority of refugees arriving to Canada between 1979 and 1980. ${ }^{13}$ However, Mayor Weeks established the Mayor's Ad Hoc Committee on Indochinese Refugees towards the end of 1977, well before the majority of refugees arrived. In this respect, Windsor was at least one year ahead of the rest of Canada in preparing for the Indochinese refugees. Testimonies from people who knew Mayor Weeks confirmed that he planned ahead. Ed Agnew, for example, said, "There is no question that [Weeks] would be the type of person who would think in advance." 14 What is more, the Government of Canada tabled a new Immigration Act in 1976, which introduced a novel concept of private refugee sponsorship, whereby civil society organizations or groups of individuals could sponsor the admission of refugees and members of designated classes. Canada's Private Refugee Sponsorship Program was officially launched in July $1978,{ }^{15}$ giving any "Group of Five" or more people the ability to sponsor refugees, so long as its members were Canadian citizens and/or permanent residents 19 years of age or older. ${ }^{16}$

The Mayor's Committee was established at the end of 1977, before the Government of Canada's Private Sponsorship Program was fully operative. It was thus created to ease the transition and integration of government-sponsored refugees into Canadian society. Sponsoring organizations did not have to sign a formal agreement to help in resettlement efforts. ${ }^{17}$ The group's initial goal was to resettle 20 Indochinese refugee families, ${ }^{18}$ and on 21 September 1978 the committee reported that 11 refugees had already arrived. The Mayor's Ad Hoc Committee would later be referred to as the Windsor-Essex Refugee Committee-an evolution of the Windsor Committee, which included communities in the surrounding area. ${ }^{19}$

The success of the committee was greatly due to the leadership of Mayor Weeks and Father Warden, and thus a description of the committee cannot be complete without a brief description of each. Albert "Bert" Weeks was a watchmaker who moved to Windsor from Montreal as a young man in the late 1940s. During an interview, his daughter, Elaine Weeks, recalled how her father often said he moved to Windsor because "it would be a good place to be mayor." ${ }^{20}$ After living in Windsor for only two years, Weeks grew frustrated with corruption in the city. According to an article in the Windsor Star, "The city was in turmoil. For one, the Windsor Police Department was rotten from the top down. Gambling operations and prostitution dominated the city streets. And at one point, police constables downtown routinely directed customers to these illegal joints along Pitt Street."21

Weeks decided to put an end to the criminality by organizing a Citizens' Action Committee. Together, the group conducted a risky investigation in order to find sufficient
(C) Author(s), 2016. This open-access work is licensed under a Creative Commons Attribution-NonCommercial 4.0 International license.
Cette oeuvre en libre accès fait l'object d'une licence Creative Commons Attribution-NonCommercial 4.0 International. 
evidence to bring down the police force. Weeks and the Citizens' Action Committee succeeded, and the provincial government removed the Windsor police chief and his deputy. ${ }^{22}$

After a close race in 1975, Bert Weeks finally got his wish of becoming mayor. During his tenure, he accomplished many memorable feats for the city. Weeks was a socialist concerned with the welfare of the people; but, at the same time, he was a great businessman. ${ }^{23}$ Edward "Ed" Agnew knew Mayor Weeks very well, having worked as the city's commissioner of finance for many years. In an interview with Agnew, Weeks is described as a strong businessman who sought out new partnerships and international linkages for the city. In June 1977, Weeks arranged a business trip to Europe, in order to negotiate such opportunities. Ed Agnew went with him. According to Agnew, Mayor Weeks had already decided to respond to the Indochinese refugees during this time, as he had asked Ed to be involved during their trip. ${ }^{24}$ Indeed, the Mayor's Ad Hoc Committee on Indochinese Refugees was created shortly after.

Father Robert Warden was a priest at St. Joseph's Catholic Church and, at this time, the co-founder and executive director at the Windsor Coalition for Development. Mayor Weeks was not a very religious person; however, Father Warden shared the same sense of civic duty and humanitarianism. As a result, the two were quite close. In fact, the mayor "appointed him as a liaison between the department heads and his office." 25 Many were displeased with this arrangement, but Weeks knew that Father Warden shared the same socialist values and was a dominant figure in the faith community who was deeply involved with the labour movement of the Canadian Auto Workers (CAW) at the time. These networks would prove to be useful in garnering public support and cooperation for the city's humanitarian initiatives. ${ }^{26}$ Archival records also indicate that Father Warden acted as an unofficial director of the mayor's committee, as many letters of correspondence were addressed to his office. ${ }^{27}$

Next, the Friendship Families program was created by the Mayor's Ad Hoc Committee on Indochinese Refugees to complement government sponsorship. Volunteer families were recruited from at least 10 different religious congregations, local non-governmental organizations, and the general public to help welcome newcomers and integrate them into Canadian society. ${ }^{28}$

Friendship Families greeted newcomers at the airport and helped them settle into their new homes. Refugees were then given "at least three days to rest and relax, before visiting with people from the congregations." 29 They were given an orientation session into Canadian life, and accompanied to file for Social Insurance Numbers and the Ontario
Health Insurance Plan (OHIP). Volunteers aided the new Windsorites with finding suitable employment, and helped them complete basic errands, including grocery shopping and the compilation of forms and applications. Perhaps most importantly, the local volunteers helped the refugee children settle into their new schools, often helping the children with their homework.The Friendship Families gained just as much from the experience as the refugees did, with one family claiming, "It has been an education on how the other half of the world lives."30

Significant sponsor "families" included members from Most Precious Blood Parish, Knox Presbyterian Church, Glenwood United Church, and St. Joseph's Church. The University of Windsor's Department of Political Science also sponsored a family with cooperation from other departments, and provided the financial resources to put them up in a house on Sunset Street, the campus artery. ${ }^{31}$ In 1980, the Windsor-Essex YMCA also became involved with resettlement efforts, under the coordination of Madeline Harden. The local branch provided funding mainly for recreational activities and English language classes, with money obtained from the Regional Settlement Office's Immigrant Settlement and Adaptation Program budget. ${ }^{32}$

Despite the relative success of the Windsor program, the experience of resettling the Indochinese refugees into "Rose City" was not all roses. At the time, Ralph Talbot was the counsellor at Canada Employment Centre's Windsor branch and an active member of the mayor's committee. In a report written by him for the Canadian Immigration Historical Society, Ralph explains how initially the Windsor community was hesitant about "adding a large group of visible minorities to the workforce." 33 As a result, he, the mayor, and "local church leaders from all denominations" met to discuss a strategy that would boost political and social support. The mayor's committee emerged from these meetings.

In an interview, Talbot describes a memorable moment at the beginning of the refugee program that shook the Windsor group. A local family was at the airport to welcome a group of refugees. It was the dead of winter, and when the group got off the airplane, they were dressed in thin clothes and sandals, many also in poor health. This event was a rude awakening and made the Windsor resettlement leaders realize that more people from the community had to be involved in this important endeavour. In Ralph's words, "It lit the fire and sparked the community." 34

Moreover, in 1978 the city was not as ethnically diverse as it is now, and there were unfortunate manifestations of racism. 35 In 1981, for example, a 15-year-old Vietnamese boy was hospitalized in the Intensive Care Unit, after being severely beaten at W. D. Lowe Secondary School. ${ }^{36}$ Ralph Talbot further indicated that racism was present even within the
(C) Author(s), 2016. This open-access work is licensed under a Creative Commons Attribution-NonCommercial 4.0 International license.
Cette oeuvre en libre accès fait l'object d'une licence Creative Commons Attribution-NonCommercial 4.0 International. 
offices of the local Canada Employment Centre, as became evident when a young Indochinese refugee he had hired suddenly quit. After pressing for an explanation, the young man admitted that he had been subject to "slurs of racial, cultural nature . . by a few of the staff." 37 Racism was a problem all sponsor communities were facing, however, and was not limited to Windsor.

In addition, some locals felt that Windsor was ignoring its own people, arguing that the support that refugees received outweighed the support given to native Windsorites in need. A member of the Windsor Housing Authority declared, "Vietnamese 'boat people' have no business taking up space in public housing units." Instead, he believed that Windsor had "a responsibility to Canadian citizens first."38 Yet, regardless of criticisms and setbacks, the Windsor community was largely very accepting of the Indochinese refugees, and there are several accomplishments worth noting.

According to a report issued by Employment and Immigration Canada, Windsor ranked fifth in the province for the number of refugees resettled between 1979 and 1980.39 In addition, Windsor was "able to maintain an $85 \%$ employment rate within the first 6-8 months of arrival for heads of households, for several years in the early 1980's."40

It would seem that the Windsor program also proved successful in integrating children into the education system. In separate interviews, Amy and Yung Hoang describe their experiences as refugee children integrating into the Canadian school system in 1980. Yung explained how the help he received from volunteers at the Knox Presbyterian Church in Leamington "profoundly affected him." Yung was one year behind in school, and when the church realized this, volunteers spent the entire summer teaching him the Grade 1 curriculum, so that by September, he would be in the same class as his age-cohort. He describes his family's "integration into the Canadian education system" as "pretty seamless" and told how this tremendous help set the course for who they are today-all successful professionals. ${ }^{41} \mathrm{His}$ sister Amy reinforced this sentiment and said, "Our family could not have been successful without the help of the community." Amy added that the Presbyterian Church became "like a second family" to the Hoangs, and the Reid family, in particular, remains a part of their lives. ${ }^{42}$

This sentiment was also echoed by Hai Nguy, a former boat person and important member of the local Vietnamese community. Mr. Nguy described how locals often commented on the achievements of Vietnamese children at school. His two children, who escaped with him and his wife, are both successful professionals. ${ }^{43}$

Moreover, the Windsor resettlement program was an original model, created by the mayor and members of the Mayor's Ad Hoc Committee. This assumption was confirmed in an interview with Ralph Talbot: I asked whether the committee was based on any pre-existing models; Ralph immediately and confidently said, "No. The program was our idea." 44 These findings challenge the current narrative that large Canadian cities, like Ottawa and Toronto, were the first to resettle Indochinese refugees. ${ }^{45}$ Mr. Talbot confirmed this theory and stated that while large Canadian cities were the leaders in resettling large numbers of refugees, Windsor was the leader in resettlement. Indeed, other Canadian resettlement projects such as Operation Lifeline and Project 4000 were developed later.

By the summer of 1979, the number of escapees reaching the shores of Southeast Asia reached record numbers, and Canadians, overwhelmed by the tragic media reports, decided enough was enough. Howard Adelman, a professor at York University in Toronto, was stunned by the humanitarian emergency and decided to do something about it. He called a meeting with the aim of writing a letter to the new minister of employment and immigration, Ron Atkey, and invited "a local Catholic priest, two rabbis, an alderman and ministers from the Anglican and United Churches to his house to discuss the crisis." To his surprise, André Pilon and Bob Parkes-civil servants from the Ontario settlement office of Citizenship and Immigration Canada-knocked on his door and asked to join. Mr. Pilon told the group about the new private sponsorship provision in the 1976 Immigration Act-a provision not many quite yet understood-and suggested that the group use it to "actually [do] something." 46 Dick Beddoes, a columnist for the Globe and Mail, heard about the event from a graduate student who sat in on the meeting. Beddoes decided to write about it, dubbing the initiative "Operation Lifeline." The rest is history. Requests to join Adelman's team came pouring in, and within less than two weeks, there were 68 chapters of Operation Lifeline across the country.

At the same time, Ottawa Mayor Marion Dewar was troubled by the plight of the Southeast Asian boat people. She organized a meeting with local leaders and civil servants and was informed that half of the Canadian quota to resettle 8,00o refugees had been reached. In an article written by Peter Goodspeed, Ms Dewar reflects on her decision: "I said, 'You've only got 4,0oo left? We'll take them."'47 Thus, Project 4000 was born.

In 1980, Ottawa was discussing the creation of a Friendship Program to "match Canadian families or individuals with government-sponsored refugees." 48 The Ottawa Friendship Program was a joint effort of Project 400o, the Ottawa-Carleton Immigrant Services Organization (ociso), and the Catholic Immigration Services (CIS), and was later renamed Canadian Friends. According to Pat Marshall from the Ontario Host Coordination Project, a consultant
(C) Author(s), 2016. This open-access work is licensed under a Creative Commons Attribution-NonCommercial 4.0 International license.
Cette oeuvre en libre accès fait l'object d'une licence Creative Commons Attribution-NonCommercial 4.0 International. 
by the name of Max Brem was researching refugee needs for Employment and Immigration Canada between 1981 and 1982, and promoted the Canadian Friends Program. Employment and Immigration decided to fund the initiative, renaming it the Host Program, and by the mid-1980s, it had expanded across the country. 49

While Operation Lifeline and Ottawa's Canadian Friends Program are well-known, they were established in 1979 and 1980 respectively-well after the Windsor program had already been established. Is it possible that the Windsor experience was used as a model? This exploratory study suggests that it was, and that the Windsor program received both national and regional attention.

\section{Windsor's Committee on Indochinese Refugees: A Model?}

\section{National Attention}

In 1977, Bud Cullen, Canadian minister of employment and immigration, announced that Canada would establish a program to admit 50 refugees from Southeast Asia per month, and an agreement was negotiated with Quebec, in this regard. On 13 January1978, Deputy Minister Jack Manion wrote Cullen to notify him of Quebec's agreement, also informing him that the mayor of Windsor had expressed an interest in assisting Indochinese refugees:

You will be interested to learn that we have been contacted by two groups that are interested in assisting small boat escapees to settle here. The Canadian Catholic Organization for Development \& Peace, operating from the Office of Archbishop Carney of Vancouver, has expressed an interest in setting up a nationwide program of assistance for boat escapees. At the same time, a committee recently established by the Mayor of Windsor has also expressed interest in assisting. We plan to give these groups every possible encouragement as they could be instrumental in generating broader public support for this program as well as in assisting individual refugee families to establish themselves here. ${ }^{50}$

This letter demonstrates that Windsor was one of the very first cities to organize itself in anticipation of the Indochinese refugee movement. This indication is confirmed in a June 1978 telex from Canadian immigration officers in Singapore, which thanked the Windsor committee, stating, "Windsor was the leading city in sponsoring refugees." ${ }_{11}$

André Pilon's presence at the Windsor Committee meetings is also extremely significant. Mr. Pilon was Citizenship and Immigration Canada's settlement director for the Ontario Region. As such, he oversaw operations across the province and reported any developments back to the federal offices in Ottawa. His physical presence and involvement with the Windsor group, along with his colleague Bob Parkes, illustrates that the Windsor model was of interest beyond the local level..$^{2} \mathrm{Mr}$. Pilon was most likely intrigued about the Windsor program and transferred his observations to the national ministry and the rest of the province. In fact, Ralph Talbot explained how Mr. Pilon and his Toronto office promoted and encouraged the Windsor Employment Office to carry on their work on the refugee file. They were pleased with the project that originated from Windsor and worked with others to transfer the model elsewhere. Over a year later, in the summer of 1979, André Pilon showed up at Howard Adelman's home-again, with Bob Parkes-for a meeting, which now marks the genesis of Operation Lifeline. It was Pilon who suggested the group use the new private sponsorship provision of the 1976 Immigration Act to resettle boat people locally. 53 Within days, the news of Operation Lifeline spread throughout Canada. Mr. Talbot also recalls from his collaboration with the Toronto office that, because of their dedication, the Ontario region and Mr. Pilon's team led in advising headquarters about resettlement initiatives between 1979 and 1980 .

Further evidence of Windsor's outreach is found in a letter from Employment and Immigration Canada to Father Robert Warden on 21 July 1978. The letter announces that 11 families have been selected for Canadian resettlement from a small boat anchored at Singapore, named the cys Hope, and acknowledges the Mayor's Ad Hoc Committee on Indochinese Refugee group's "willingness . . to help the small boat escapees establish in Windsor." As such, Employment and Immigration Canada requested that Windsor take in three families, in addition to a 17-year-old boy, whose parents "could only pay for his escape." 54 A telex issued "on behalf of the United National High Commissioner for Refugees" compliments this letter and confirms that refugees from this group landed in Windsor in September 1978.55 This letter and telex also illustrate that Windsor initiated the resettlement of refugees well before the massive refugee movement commenced in 1979.

Furthermore, in October 1978, a boat carrying 2,500 refugees from Vietnam was refused entry into Malaysia. The Hai Hong remained anchored off the coast, without sufficient food, water, or medical supplies..$^{6}$ On 14 November 1978, Mayor Bert Weeks wrote to Bud Cullen to update him on the activities of the Mayor's Ad Hoc Committee. (A copy was sent to then Prime Minister Pierre Trudeau and local members of Parliament.) The main purpose of the letter, however, was to urge the Canadian government to do something about the Hai Hong crisis. The mayor wrote, "While we recognize the effort already being made by your Government on behalf of Indo-Chinese refugees, a special gesture of humanitarianism would appear to be warranted in this situation. If Canada would for example, announce a willingness to accept an additional 500 persons, beyond the numbers already agreed to, it could serve to inspire other countries to act on behalf of the remainder." 57
(C) Author(s), 2016. This open-access work is licensed under a Creative Commons Attribution-NonCommercial 4.0 International license.
Cette oeuvre en libre accès fait l'object d'une licence Creative Commons Attribution-NonCommercial 4.0 International. 
A few days later, Minister Cullen announced that Canada would accept 604 Hai Hong refugees. Other countries followed suit, as per Weeks's prediction..$^{8}$ Was Minister Cullen influenced by Mayor Weeks's letter? Interviewees say he probably was. ${ }^{59}$ The letter also proves that Minister Cullen and Mayor Weeks had already been in contact earlier in the year, as the mayor cites past correspondence.

In sum, these primary sources are significant, as they demonstrate that the Windsor model did, indeed, receive national attention and suggest the possibility that Windsor may have very well influenced Canadian policy. It would be interesting to explore this last point in greater depth through additional research.

\section{Regional Attention}

As one of the first cities to organize itself in anticipation of the flood of Indochinese refugees, the Windsor program received regional attention, particularly from Edmonton, Alberta. In October 1978, Alice Colak from the Catholic Services of Edmonton wrote to churches throughout the city, alerting them to the growing refugee crisis and the possibility of sponsoring refugees under the new sponsorship program created by the 1976 Immigration Act. The letter explains how committees have already been established throughout the nation to assist resettlement of refugees in Canada, and cites Windsor as a prime example. The letter also encloses an article about the "project in Windsor, Ontario."6o

The public reception of the Windsor resettlement model must have been favourable because on 23 November 1978 , Father Warden was invited to be a lead speaker at a workshop organized by the Edmonton Catholic Immigrant Services and Social Justice Commission, regarding the "Sponsorship of Vietnamese Refugees." Father Warden was to inform the audience about the experiences of the Windsor "Committee Concerning Vietnamese Refugees." ${ }^{1}$

Between late 1979 and the early 1980s, Ralph Talbot also recalls attending several conferences across the province to promote the Windsor experience, in addition to Calgary (Alberta) and Quebec. These gatherings took place in order to understand what was happening across the country and to share best practices. Mr. Talbot remembers jokingly telling other representatives that the national response started in Windsor: "We did it before you," he would say in good humour.

These pieces of primary information confirm that the Windsor program may have very well been used as a model for other communities. Unfortunately, sources that discuss Windsor's Friendship Families program are in short supply. From the information obtained, however, it would seem that the program was a precursor to Canada's Host
Program and Operation Lifeline. The extent to which the Windsor model influenced these well-known initiatives, however, is unknown and would be a fascinating topic for future studies.

\section{Concluding Remarks}

This article has described the Windsor resettlement program during the Indochinese refugee movement, comprising both the Mayor's Ad Hoc Committee on Indochinese Refugees and the Friendship Families program. It has demonstrated how the Windsor program gained national and regional attention, and may have served as a model for communities beyond even Ontario, predominantly in Alberta. Several conclusions and lessons can be learned from this case study experience.

First, Windsor's local efforts to sponsor and integrate Indochinese refugees into Canadian society seem to have been ground-breaking. This article has illustrated how the Windsor model-comprising the Mayor's Ad Hoc Committee on Indochinese Refugees and the Friendship Families program - was an original and avant-garde model, as it was organized well before the "flood of refugees" arrived in 1979. This evidence challenges the national narrative that large Canadian cities led in resettling the boat people. What is more, archival documents have illustrated that this local model received national and regional attention and may have inspired national action from the minister of employment and immigration, Bud Cullen. It was also instrumental in gaining wider public support in the country, particularly in Edmonton. Indeed, Windsor was pivotal in shaping the Canadian response to the Indochinese refugee crisis.

Although the community was legally responsible for the well-being of the refugees only one year from their arrival, the friendships and bonds that grew out of the Windsor resettlement initiatives lasted a lifetime. There are important lessons and best practices that can be drawn from Windsor's seminal efforts. These lessons include the importance of strong leadership, community engagement, and multilevel partnerships. Future studies could compare local Canadian models or explore the extent to which the Windsor model was transferred elsewhere.

By recounting this untold piece of local history, I hope readers have a greater appreciation for the important role localized communities play in forging responses to humanitarian crises. Today, the world is facing another humanitarian crisis of global proportions, and Canada is leading in resettlement efforts. ${ }^{62}$ I would encourage all those working towards this end to be cognizant of the impact of their efforts and to preserve their records, so that historians will be able to measure their impact for generations to come. 


\section{Notes}

1 Peter Duschinsky, "The Human Side of the Fall of Saigon," CIHS Bulletin 73 (April 2015): 1-16, http://cihs-shic.ca/wpcontent/uploads/2015/04/Bulletin-73-Final-with-Milburncorrection.pdf.

2 Ibid.

3 Employment and Immigration Canada, "Part 1: Indochinese Refugees: The Canadian Response, 1979 and 1980," http://cihs-shic.ca/wp-content/uploads/2015/o3/Indochinese-Refugees-Cdn-Response-report-EnG.pdf, 5. See also Michael Lanphier, "Refugee Resettlement: Models in Action," International Migration Review 17, no. 1 (1983): 6.

4 Gertrud Neuwirth and Lynn Clark, "Indochinese Refugees in Canada: Sponsorship and Adjustment," International Migration Review 15, nos. 1-2 (1981): 131-40; Howard Adelman, Canada and the Indochinese Refugees (Regina: L. A. Weigl Educational Associates, 1982); Michael Lanphier, "Refugee Resettlement: Models in Action," International Migration Review 17, no. 1 (1983): 4-33; Kwok B. Chan and Doreen Marie Indra, Uprooting, Loss and Adaptation: The Resettlement of Indochinese Refugees in Canada (Ottawa: Canadian Public Health Association, 1987).

5 Linda Marshall writes about the resettlement of the Indochinese refugees in Windsor, Ontario; however, she does so from a social work perspective. The focus of the work is to evaluate needs of the local Indochinese refugees, not the actual model itself. See Linda Marshall, "An Exploratory Study on the Resettlement of the Indochinese Refugees in Windsor, Ontario" (MA thesis, University of Windsor, 1981).

6 The Windsor Star has a digital archive available online for all publications; however only editions published after 1980 are indexed. Editions preceding this date are indexed in the Windsor Public Library's card catalogue.

7 These organizations include the Windsor Coalition for Development, the local branch of Citizenship and Immigration Canada, the Windsor Essex County Local Immigration Partnership (WELIP), the local YMCA, and the Multicultural Council of Windsor and Essex County.

8 I am extremely grateful to Ralph Talbot for providing me with committee minutes from his personal files. Unfortunately, the City of Windsor archives office was not able to retrieve these files.

9 Dr. Ron Wagenberg, professor emeritus of political science, University of Windsor, in discussion with the author, 4 December 2014.

10 Best of the Times Magazine, 2006 Edition (Windsor: Walkerville Publishing 2006), 402.

11 The total number of resettled refugees is much higher, when privately sponsored refugees are taken into account. Unfortunately, I could not acquire a number of private sponsorships. Such a task requires access to the records of all private sponsors, including churches, non-governmental organizations, and groups of five or more. The groups I contacted did not keep these files on record. The number of 1,903 government-sponsored refugees is taken from the personal records of Ralph Talbot.

12 The first official, documented meeting of the Mayor's Committee took place on 15 March 1978 (see Marshall, "Exploratory Study"). However, multiple testimonies indicate that the mayor had, indeed, organized the group as early as late 1977 .

13 Frank Frost, "Vietnam, ASEAN and the Indochinese Refugee Crisis," Southeast Asian Affairs 7 (1980): 347-67.

14 Ed Agnew,former commissioner of finance at the City of Windsor, in discussion with the author, 8 December 2014.

15 Canadian Immigration Historical Society, "A Chronology of the Indochinese Refugee Movement 1975-80," http:// cihs-shic.ca/wp-content/uploads/2015/o3/A-Chronologyof-the-Indochinese-Refugee-Movement-1975.pdf.

16 For a schematic outline of the Canadian sponsorship system, see the Canadian Immigration Historical Society, "Sponsorship System," http://cihs-shic.ca/wp-content/ uploads/2015/o3/Sponsorship-Chart-1978-corrected.pdf.

17 "First Vietnamese Refugees May Be Here Next Month," Windsor Star, 8 August 1978.

18 "Mayor's Committee:Vietnamese Refugees," minutes, 22 June 1978. From the personal records of Ralph Talbot.

19 Ralph Talbot,former Canada Employment Centre counsellor, in discussion with the author, 28 November 2014.

20 Elaine Weeks,daughter of Bert Weeks, in discussion with Michael Molloy and Giovanna Roma, 17 November 2014.

21 "Former Mayor Bert Weeks Possessed Vision, Courage," Windsor Star, 17 December 2010.

22 Ibid.

23 Agnew, in discussion with the author; Weeks, in discussion with Molloy and Roma, 2014.

24 Ed Agnew added that he respectfully declined the offer of being directly involved with the Committee on Indochinese Refugees because at that time, he was too busy with his own job at the City. Agnew, in discussion with the author.

25 Ibid.

26 Ibid.

27 The Indochinese Refugee Newsletters, issued by the Conservative minister of immigration, lists the Windsor Mayor's Committee on Refugees as an organization involved with refugees. The address associated with the committee is St. Joseph's Church, 4258 Seminole Street, Windsor. (See Indochinese Newsletter 1, no. 13, 18 October 1979). A second letter, from the office of Employment and Immigration Canada, Ottawa, addresses Father Robert Warden, Mayor's Ad Hoc Committee on Indo Chinese Refugees, at his church office at 686 Marentette Avenue.

28 "First Vietnamese Refugees," Windsor Star.

29 "Mayor's Committee: Vietnamese Refugees," minutes, 21 September 1978. From the personal records of Ralph Talbot.

30 Susan Semenak, "Refugee Family Ends Journey with Big Step into Citizenship," Windsor Star, 11 December 1981.
(C) Author(s), 2016. This open-access work is licensed under a Creative Commons Attribution-NonCommercial 4.0 International license.
Cette oeuvre en libre accès fait l'object d'une licence Creative Commons Attribution-NonCommercial 4.0 International. 
31 Wagenberg, in discussion with the author.

32 Talbot, in discussion with the author; Marshall, "Exploratory Study," 16. I also spoke to the current general manager of settlement and integration, who was able to confirm the YMCA's past involvement.

33 Ralph Talbot, "South East Asian Refugee Settlement in Windsor, on," for the Canadian Immigration Historical Society, 2013.

34 Talbot, in discussion with the author.

35 Ibid.; see also Ralph Talbot, "Racists Hurt Themselves," Windsor Star, 31 August 1982.

36 Marshall, "Exploratory Study," 19; "Racism: Air Needs to Be Cleared," Windsor Star, 25 March 1981, p. 8.

37 Talbot, in discussion with the author.

38 "WHA Official Blasts Housing of Refugees," Windsor Star, 22 November 1979.

39 Employment and Immigration Canada, "Part 2: Indochinese Refugees."

40 Talbot, "South East Asian Refugee Settlement."

41 Yung Hoang is a professional engineer and an engineering director at Amec Foster Wheeler, Nuclear Canada, Toronto. Amy is a teacher at the David Suzuki School in Windsor, Ontario. Their sister Stephanie is an interior designer and their brother Adam works in information technology. Yung Hoang, in discussion with the author, 12 March 2015.

42 Amy Hoang, teacher, in discussion with the author, 16 March 2015.

43 Hai Nguy, owner of Hai-Ho Furniture, in discussion with the author, 16 March 2015.

44 Talbot, in discussion with the author.

45 The concept of a "narrative" was borrowed from conversations with Prof. Michael Molloy.

46 Peter Goodspeed, "Can Canada Duplicate Its Boat People Rescue with Syrian Refugees?” Toronto Star, 26 September 2014, http://www.thestar.com/news/atkinsonseries /2014/o9/26/can_canada_duplicate_its_boat_people_rescue_with_syrian_refugees.html.

47 Ibid.

48 Pat Marshall, "From Friends to Hosts to Friends," CIHS Bulletin 55 (2009): 1-3.

49 Ibid.

50 Jack L. Manion, deputy minister, to Bud Cullen, minister of employment and immigration, 13 January 1978, Refugees and Displaced Persons, Special Movements, Indochinese, file 8700-15, vol. 1838, RG 76, Library and Archives Canada.

51 Committee Minutes, 8 June 1978; see Marshall, "Exploratory Study," 7.

52 Both Pilon and Parkes were present at a Mayor's Committee meeting on 22 June 1978.

53 Goodspeed, "Can Canada Duplicate Its Boat People Rescue."

54 Employment and Immigration Canada to Father Robert Warden, 21 July 1978.

55 Y. Y. Kim, resident representative, on behalf of the United Nations high commissioner for refugees, telex, 4 July 1978. Letter obtained from an anonymous source.

56 Dara Marcus, “The Hai Hong Incident: One Boat's Effect on Canada's Policy towards Indochinese Refugees," Canadian Immigration and Historical Society, http://cihs-shic. ca/wp-content/uploads/2013/10/Marcus_IMRC_Submission.pdf.

57 Mayor Bert Weeks to Bud Cullen, minister of employment and immigration, 14 November 1978.

58 Dara Marcus, "Saving Lives: Canada and the Hai Hong," Bout de Papier 28, no. 1 (2013): 26.

59 Indeed, Mayor Weeks's daughter, Elaine, says that the fact Cullen announced his decision regarding the Hai Hong just days after receiving her father's letter "probably wasn't a coincidence." Minister Cullen represented the SarniaLambton riding from 1968 to 1984 (a riding in Southwestern Ontario, like Windsor), and he would have certainly known Mayor Weeks, as well as the city's humanitarian reputation.

60 Alice Colak, Edmonton Interfaith Immigration Committee, Catholic Social Services, Edmonton, 26 October 1978.

61 Catholic Social Services of Edmonton, "Sponsorship of Vietnamese Refugees," 13 November 1978.

62 Adrian Edwards, "Needs Soar as Number of Syrian Refugees Tops 3 Million," UNHCR, 29 August 2014, http://www .unhcr.org/53ff76c99.html.

Giovanna Roma was a research associate at the University of Windsor from 2013 to 2015. The author may be contacted at giovannaroma2@gmail.com 


\title{
Book Reviews
}

\author{
From the Land of Shadows: War, Revolution and the Making of the Cambodian Diaspora \\ $\sim$ \\ Khatharya Um \\ New York: New York University Press, 2015, 329 pp.
}

\author{
Southeast Asian Migration: People on the Move in Search of Work, Refuge and Belonging \\ $\sim$ \\ Edited by Khatharya Um and Sofia Gaspar \\ Chicago: Sussex Academic, 2016, 230 pp.
}

$\mathrm{S}$ outheast Asia is a place of diverse cultures, peoples, and histories. The books under review here add breadth and depth to the lives of people in and/or from that region of the world. Today, Southeast Asia is imbued with meanings of home and homeland for thousands of people living abroad, from Hmong to Vietnamese and from Filipinos to Cambodians.

Since the 1970s, many books have been published about the Southeast Asian diaspora. Khatharya Um's From the Land of the Shadows is one of the latest to address what happened specifically in Cambodia in the 1970s under the Khmer Rouge and the subsequent dispersal of Cambodian refugees around the world, following one of the deadliest genocides in human history. Organized into three parts and seven chapters, this book provides coherence and continuity to our understanding of the experiences of Cambodians in Southeast Asia and the lives of Cambodian Americans in the United States. Many Cambodian Americans are looking back on that tragic saga and searching for new meanings to anchor their identities. Like other Southeast Asian refugee immigrants, they are at crossroads where longing for the past is central to their ongoing identity development and formation. That past, although filled with difficult memories, is inseparable from their lives in the present. "For the younger-generation diasporas, 'return' is not just going back to the past," Um writes, "but addressing the past in order to go beyond it, to pay homage to the painful history and the challenges of exile but also to the internal strengths of the diasporic communities" (251). For many, what constitutes this painful history is still vivid in their minds. Nearly "two million of the country's estimated seven million people" (2) perished from hard labour, disease, starvation and execution and 600,000 Cambodians were forced to flee their ancestral homeland. Over 100,000 would end up in the United States as refugees, fleeing the Vietnam War and Khmer Rouge atrocities.

Through Khatharya Um's telling, what happened in Cambodia is not an isolated event. From her analysis, we see that the disparate histories of nations are linked in ways that are not always immediately obvious. Indeed, there are many layers to the larger story in Cambodia, all of which Um did an admirable job of untangling. Individual accounts, obtained from extensive interviews of adult and child survivors, are overlaid with political divisions within Cambodia; regional tensions encompassing Cambodia, Vietnam, and China; and colonial interests buttressed by French and American foreign policies. The conflicts in Southeast Asia, spanning decades starting in the 1940s, are local, regional, and international. Evidence of the magnitude of the violence and its aftermath are still visible in the form of physical, emotional, and psychological scars on the bodies of survivors, including children. In this regard, the chapter titled "The Children of Angkar" is especially compelling. The voices of those who lived through the conflicts in Southeast Asia as young children are given far too little emphasis in scholarly writing. I find the memories of Um's interviewees (who are now adults) to be an important dimension of Cambodian American history. The resilience of these individuals is remarkable and a testament to people's capacity to rise from the ashes of history.

Um gives clarity to a very complex history. Um is herself a Khmer who is now contributing to higher education through research and teaching at the University of California-Berkeley. This is an important note to consider within the context of the history of scholarship on Southeast Asia 
in general, and Cambodia Americans in particular. The gaze on Southeast Asia has traditionally been a Western one. What contributions can indigenous scholars add to the burgeoning scholarship on the history of Southeast Asia and on the Southeast Asian American experiences? Within the framework of Asian American studies, how visible are the stories of Cambodian Americans? These are perplexing interdisciplinary questions that Um takes into consideration in framing her work. I applaud her for placing the narratives of her informants at the confluence of competing local, national, and global stories. In this highly textured book, we can see how central the Cambodian American experience is to the exploration of open-ended concepts such as home, homeland, exile, belonging, and return.

Within the last five decades, how has Southeast Asian migration added to the debate on the meaning of transnational? How are they a part of the modern flow of people that has challenged our understanding of national borders, or of home and homeland? More specifically, how are Southeast Asians rebuilding their lives outside of Southeast Asia? These questions are central to Southeast Asian Migration: People on the Move in Search of Work, Refuge and Belonging. Nine chapters explore a broad range of issues related to Southeast Asian communities in Europe, the Middle East, Southeast Asia, and the United States. "Of the world's 105.5 million migrant workers, an estimated 14 million are from Southeast Asia, of whom 9 million are from the Philippines." The chapters in this volume reflect this staggering number; four out of the nine chapters are devoted to the lives of Filipinos living in Italy, France, United Arab Emirates, and the United States. The remaining five chapters focus on Vietnamese families in Poland; Hmong American individuals whose identities straddled several countries simultaneously; Cambodian migrant workers in Thailand; displaced Southeast Asian refugees living at the Burmese-Thai border; and political activism among younger generations of Cambodians in the West, especially the United States.

Based on original ethnographic fieldwork research, South east Asian Migration is aimed at a vast audience that includes "academicians, advocates, policy makers, and concerned citizens" (3). As the editors cogently note, the lives explored in this anthology are diverse, complex, and dynamic. Taken together, the chapters highlight key themes, concepts, and issues that continue to generate discussion and debate in the field of migration and/or Southeast Asian diasporic studies. One concept in particular is that of generation. Who are the first generation? Who constitute the 1.5 generation? And who are the 1.8 generation? Why do these distinctions matter? As the contributors have collectively affirmed, they matter because generational differences are an important dimension to our understanding of the complex changes that accompany adaption as people incorporate new values, ideals, and traditions into family and community life. Generational differences in attitude, or in the rate of acquisition of host country languages, for example, are sources of tensions that can permanently alter the dynamics of the family (e.g., chapters by Asuncion Fresnoza-Flot and Grazyna Szymańska-Matusiewicz). For the first generation, there is a robust desire to retain their cultural heritage as much as possible. People's outlooks are still informed by the teachings of their parents and grandparents. Much of their identity is invested in traditional practices linked to the "homeland." For their children, the concern is no longer solely about preserving self and culture, but more about inserting themselves strategically in the present. How do they fit into modern society as citizens of the world? How can they adapt so that they can take advantage of the opportunities not readily available to their parents? Moreover, can ideas of family be redefined, as people acquire new awareness and sensibilities, to include interracial marriages, or even gay and lesbian partnerships? What's to become of their identities as Southeast Asians learn to be Polish, Italians, Americans, or Emirati?

As the case studies in this volume suggest, Southeast Asians have established vibrant communities in many places around the world. In turn, they also are having to face perplexing issues head on. For example, in many of the communities cited, it is necessary for people across generations to reassess their sense of place and belonging. What can we learn about how they are asserting themselves in order to claim their place in their respective communities? Belonging is achieved through social integration and collective responses to both internal and external pressures. On the one hand, belonging is a bodily experience: it is visceral and intimately personal. On the other, it is political, grounded in ideas of birth, nationality, and citizenship. Belonging is embedded in the narratives of individuals regarding who they are, where they live, where they came from, and what they hope to become. Belonging is thus a fluid and elusive concept, informed by everyday decisions and choices as people live out their lives. The experiences of Southeast Asian migrants represent an important dimension to our understanding of the consequences of the global flow of people in the 21st century. Their stories of change and infinite possibilities are a global story. The voices emanating from this anthology reveal the balancing act (10) required of all of us as contemporaries in a world marked by fascinating changes.

Vincent K. Her, associate professor of anthropology at the University of Wisconsin-La Crosse, can be reached at vher@ uwlax.edu.
(C) Author(s), 2016. This open-access work is licensed under a

Creative Commons Attribution-NonCommercial 4.0 International license.
Cette oeuvre en libre accès fait l'object d'une licence Creative Commons Attribution-NonCommercial 4.0 International. 


\section{Migration by Boat: Discourses of Trauma, Exclusion and Survival \\ Edited by Lynda Mannik \\ New York: Berghahn Books, 2016, 290 pp.}

\section{"W} hat are the Rights of Man and the Liberties of the World but Loose-Fish?", quipped Herman Melville in Moby-Dick. Migration by Boat: Discourses of Trauma, Exclusion and Survival elaborates this query. This impressive collection of essays, centred on migration, borders, identities, and humanitarian ideals is both theoretically astute and ethnographically rich. Each contribution is solid and together they challenge readers to rethink the politics of migration.

Human rights became a global force with the founding of the United Nations after the Second World War, and yet this volume documents the countless ways that our humanity remains a slippery commodity, our rights a "Loose-Fish" that is fair game to take or squander. The Universal Declaration of Human Rights addresses freedom of movement and asserts in Articles 13 and 14 respectively that "everyone has the right to leave any country, including his own" and that "everyone has the right to seek and enjoy in other countries asylum from persecution." Refugees have been accorded a distinct legal status under international law since 1951. The principle of non-refoulement is an essential component of this status, articulated in the statement in Article 33(1) of the United Nations Convention relating to the Status of Refugees that "no Contracting State shall expel or return a refugee in any manner whatsoever to the frontiers of territories where his life or freedom would be threatened." Member states are obligated to aid asylum-seekers at their borders. The Un International Convention on the Rights of Migrant Workers and Their Families (adopted in 1990 and entered into force in 2003) also emphasizes that human rights apply to all migrants and their families. Despite this rhetoric of rights, sovereign nations increasingly imperil migrants and avoid humanitarian action through devious tactics that include depoliticizing migration, deflecting would-be migrants and asylum-seekers through policies of deterrence and enforcement, exorbitant visa costs, complex bureaucracies, and tightened security measures. Asylum-seekers and "irregular migrants" have been routinely returned to the desperate situations they have fled. Others are held in offshore detention camps. A rhetoric of fear, voiced by political actors and echoed in the media, presents migrants as threats to state borders and national security. The rights of refugees and migrants are further negated through strategies that result in statelessness and invisibility. Categories, such as "offshore entry persons," "excludable aliens," and "irregular" or "Illegal migrants" strip individuals of rights and trap migrants and asylum-seekers in a perilous limbo. Perhaps even more alarming, many of those lost at sea remain nameless and uncounted, disappeared between shores that offer only policies of violence, hopelessness, rejection, and neglect.

The chapters in Migration by Boat employ interdisciplinary perspectives in order to cast a wide net and bring to light the human drama of migration across bodies of water. Particular attention is focused on the perils of those who have come to be known as "boat people." An overarching concern of contributing authors for human life and dignity and a challenge to indifference lend both urgency and timeliness to the text. Despite the right to safe passage for "ships of all States" specified by the United Nations Convention on the Law of the Seas (Article 17) and the obligation of "masters of ships" to "proceed with all possible speed to the rescue of persons in distress" (Article 98), Europe has fortified itself against migrants, militarizing its southern seaboard in an effort to deter migrant travel. Chapters in this volume estimate that some 30,000 individuals have perished trying to reach its borders by sea since 2000. This number has risen significantly since the volume went to press. Similarly, an estimated 2,000 migrants are thought to have drowned en route to Australia between 2000 and 2013. Australia has responded to asylum-seeker boats with policies of interception and detention.

Migration by Boat documents flows of migrants traveling across water and approaches this topic through creative and varied themes. Articles include a review of children's literature on the "home children" in Canada that offers a reinvigorated appreciation for the role that children's books play in forming a nation's collective memory. A chapter by Kim Tao discusses efforts by the Australian National Maritime Museum to restore and display the Vietnamese fishing boat Tu Do-a boat that brought 31 refugees to Australia in 1977 after the fall of Saigon. Tao offers a riveting account of the boat-builder's daring flight and 3,700-mile journey from Vietnam to Australia and demonstrates the power that material artifacts hold in communicating ideals of freedom and courage. Tao also notes that such stories of heroic perseverance can help shape public opinion regarding contemporary border policies. A chapter by volume editor Lynda Mannik details events surrounding the arrival of the Amelie, a freighter crowded with Sikh refugees, that
(C) Author(s), 2016. This open-access work is licensed under a Creative Commons Attribution-NonCommercial 4.0 International license.
Cette oeuvre en libre accès fait l'object d'une licence Creative Commons Attribution-NonCommercial 4.0 International. 
dropped anchor in the tiny fishing hamlet of Charlesville, Nova Scotia, in 1987. Some village residents greeted the refugees with sandwiches and tea before they were "whisked away and relocated" by government agents. Mannik revisits the "social drama" that ensued, contrasting an overwhelmingly negative discourse of breached borders and national threat with the simple hospitality offered by Charlesville residents. In a similar juxtaposition, Linda Briskman and Michelle Dimasi detail efforts by residents of the Australian Territory of Christmas Island to rescue men, women, and children from the wreck of the Janga, an asylum-seeker boat that was dashed to pieces in stormy weather. While dominant Australian narratives cast shipwrecked migrants as unwelcome invaders, residents of Christmas Island reacted with compassion and sought to aid and comfort survivors. Articles on art installations and performances, museum exhibits, the protests of mothers of migrant children "disappeared" in transit, as well as discussions of works of fiction help to clarify the often nightmarish labyrinth of hostility and fleeting moments of hospitality encountered by asylumseekers. The volume is organized in four sections: "Embedded Memories for Public Consumption," "The Artist and the Illegal Migrant," "Media, Politics and Representation" and "Stories of Smuggling, Trauma and Rescue."

The breadth of topics in this volume holds the reader's attention while maintaining an unwavering focus on the most basic rights of life and liberty. The slipperiness of human rights, however, lies in the fact that sovereign states are responsible for creating the infrastructure through which these rights are made possible. Readers may desire more emphasis on the structural violence that propels desperate citizens to risk all on the open seas or the smug complicity of those who fortify their borders and darken the lighthouses, orchestrating crimes against humanity as "accidents." To the editor's credit, no single, simple cause or solution is presented. Readers will do well to consider the entire volume and to reflect on the powerful image of boats made of rotted planks, weighted beyond capacity with the fragile aspirations of our children. Who has the courage to offer safe harbour? The authors assembled here are not counting on sovereign states to take the lead.

This is a collection that is both useful (for classroom or curatorial purposes) as well as transformative. Authors draw on nearly a century of social science theory, including Hannah Arendt, Victor Turner, Giorgio Agamben, and Jacques Derrida, without contrivance or pretense. But perhaps the most satisfying quality in this collection results from the ways that each author engages a community beyond academia. There is a prevailing concern for actions, metaphors, or images that transform. Too often, when grave violations of human rights are acknowledged at all, readers are left with a sense of helpless despair. How can safe migration be facilitated? How can new arrivals be incorporated into the social body and national identity? These chapters detail specific effects that individual acts, narratives, protests, exhibits, or performances can have, shifting public perception and, perhaps, changing public policy. The volume seeks to make visible those who have been lost at sea or swallowed in the gaps and holes of global discourses of population management, national identity, and state security. It also charts immediate and strategic ways in which individuals and their communities might hold fast the Rights of Man after all, even in these turbulent and cynical times.

Diana M. Dean is community faculty at Metropolitan State University in Saint Paul, Minnesota. The author can be contacted atdiana.dean@metrostate.edu.

\title{
Unsettled: Cambodian Refugees in the New York City Hyperghetto
}

\author{
n \\ Eric Tang \\ Philadelphia: Temple University Press, 2015, 220 pp.
}

$\mathrm{E}$ ric Tang's Unsettled: Cambodian Refugees in the New York City Hyperghetto is an important contribution to the literature on Southeast Asian refugees in the United States. As the title conveys, the book challenges the image of Cambodian refugees in the Bronx section of New York City as "saved," or resettlement as a "solution," either to the war in Indochina or to what Tang characterizes as a "veritable war" against the poorest residents of America's cities. The term hyperghetto, which Tang takes from sociologist Loïc Wacquant, refers to the idea that the poorest urban residents are no longer seen as useful by the state or corporate America. Instead of being recruited into the lowest levels of the workforce, they can only be held captive, imprisoned by harsh regulation in the welfare system and physically disciplined and controlled by an increasingly militarized police. ${ }^{1}$
(C) Author(s), 2016. This open-access work is licensed under a Creative Commons Attribution-NonCommercial 4.0 International license.
Cette oeuvre en libre accès fait l'object d'une licence Creative Commons Attribution-NonCommercial 4.0 International. 
Just over half of Cambodian refugees, survivors of the Khmer Rouge atrocities of displacement, forced labour camps, starvation, and mass executions, and years in terrible conditions in refugee camps in Thailand, found themselves relocated to these poor and violent inner city landscapes. Tang argues that contrary to some analyses, Cambodians were not racialized into the underclass-rather they were seen as different from the other residents of the hyperghetto, a pattern he terms "refugee exceptionalism." Cambodians were resettled there, but only temporarily, until they would inevitably be "saved" and leave. Their supposed ability to do so positions them in sharp contrast to the so-called undeserving domestic minorities, and justifies the harsh treatment by the hyperghetto. Refugees are doubly rescued, from us imperialist policies that brought war to Cambodia, and from us domestic policies that enslave those in the inner cities. The rub here is that, for most Cambodians in the Bronx, the redemptive storyline never plays out; they are trapped in the violent captivity of the urban centre.

Tang constructs the argument by telling the story of a woman named Ra Pronh, her husband Heng, and their seven children. Her story describes her forced marriage to Heng under the Khmer Rouge regime, her life in the refugee camps, and resettlement in the Bronx in 1986. Crucial to this telling is the concept of "refugee temporality," Tang's notion that across all these circumstances there is no turning point, no freedom, but rather a familiar ongoing sense of entrapment that Ra resists through continual movement. Chapter 2 focuses on housing, following Ra and her family as they move through a series of appalling unheated, substandard apartments. Chapter 3 analyzes Ra's family's dependence on and resistance to the welfare system, especially after the changes to the system in 1996 . Here Tang draws on his own engagement with the community by working with the Young Leaders Project to resist these changes.

Chapter 4 analyzes workfare and the "welfare trap." Workfare was supposed to take so much of the recipients" time they could not "cheat" with outside cash employment, while at the same time welfare did not provide enough income to survive. Instead $\mathrm{Ra}$ and others choose homebased, sweatshop production, what Tang in chapter 5 calls "the sweatshops of the neoplantation." Here Tang makes the good point that discussions of "global cities" or the "third worlding" of us cities usually focus on ethnic enclaves and miss the global sweatshop workers of the hyperghetto. Finally, chapter 6, "Motherhood," focuses on the destruction of family by the combined social service and criminal justice systems. Ra, in striking out at a man she perceives as threatening her daughter, is convicted of assault. Then, after saying in a counselling session that she had hit her child, she is restricted from access to her youngest son. Tang analyzes the violence of the hyperghetto as gendered, where Black women are cast as deviants, criminals, and "bad mothers." Cambodian women do not suffer quite the same casting but are subjected to a different form of racist gendering-the need to be saved from their own backward culture. In the conclusion, $\mathrm{Ra}$ is injured in a traffic accident, becomes eligible for Supplemental Security Income (a federal income supplement), and is finally relieved of the stress of needing multiple forms of income. At the time the book was written, five of the seven children had full-time jobs and two had finished undergraduate university degrees, but Tang cautions that the "specter of chronic unemployment and welfare dependency still loomed" (168). Only the child who had become a hair stylist in Manhattan felt he was on a path to long-term economic security.

Tang is writing against earlier work on refugees in the United States, which focused on cultural groups without giving adequate consideration to the context where they were resettled. Indeed this is the key contribution of the book. At the same time, Unsettled could have benefitted from including some references to Cambodian cultural models-not as a reified, static system, but as one source of ideas from which $\mathrm{Ra}$ and others who left Cambodia as adults are no doubt drawing. Instead Tang seems to go to great lengths to avoid this approach. When the Cambodians he is trying to help organize have their own ideas about how to stage a protest, Tang turns to Paulo Freire on education (108-9); or when discussing resistance he introduces the idea of "blues epistemology," which critiques "linear progressive narratives" (133). These concepts may be fruitful sources for understanding the hybrid cultural world of Cambodians in the Bronx, yet surely $\mathrm{Ra}$ is also using concepts of social hierarchy and Buddhist notions of cyclical time drawn from the cognitive map from her youth. Buddhism appears only once in the text, when Ra's daughter says about a Buddha image in the living room, "We never forget religion." Understanding Ra's choices, within the limits of the hyperghetto world, would have benefitted from considering her cultural roots. Tang's work thus complements earlier work by Nancy Smith-Hefner, Aihwa Ong, and others; taken together with and contrasted with these works, Tang's book helps flesh out our understanding of the lives of Cambodians in the United States. ${ }^{2}$

Finally, on sexual violence, Tang writes, "Khmer Rouge soldiers routinely raped Cambodian women" (139). In the early historical work on the period, rape was said to have never occurred, since the Khmer Rouge punished those who violated the strict code of conduct for their own cadre with death. We know from first-person accounts published later that rape did occur, but most often when the crime could be hidden, such as just before women were to be executed. From my knowledge of this literature, it is inaccurate to call this
(C) Author(s), 2016. This open-access work is licensed under a Creative Commons Attribution-NonCommercial 4.0 International license.
Cette oeuvre en libre accès fait l'object d'une licence Creative Commons Attribution-NonCommercial 4.0 International. 
"routine." Tang also represents all Khmer Rouge era "forced" marriages as negative and violent, citing Peg Levine's work; but in fact she takes issue with this characterization, even questioning the word forced. Part of Ra's "captivity" is that she remained in such a marriage, but Levine points out that the majority of such marriages endured, partly because of the bonds created by the struggle to survive the Khmer Rouge era. ${ }^{3}$

\section{Notes}

1 Loïc Wacquant, "Deadly Symbiosis: When Ghetto and Prison Meet and Mesh," Punishment and Society 3, no. 1 (2001): 95-133.
2 Nancy Smith-Hefner, Khmer American: Identity and Moral Education in a Diasporic Community (Berkeley: University of California Press, 1999); Aihwa Ong, Buddha Is Hiding: Refugees, Citizenship and the New America (Berkeley: University of California Press, 2003).

3 Peg Levine, Love and Dread in Cambodia: Weddings, Births, and Ritual Harm under the Khmer Rouge (Singapore: National University of Singapore Press, 2010).

Judy Ledgerwood is director, Center for Southeast Asian Studies, and professor, Department of Anthropology, at Northern Illinois University. She may be contacted at jledgerw@niu .$e d u$.

\section{Across the Seas: Australia's Response to Refugees-A History

\author{
$\infty$ \\ Klaus Neumann \\ Carlton, AUs: Black, 2015, 352 pp.
}

$\mathrm{I}$ n his latest book, Klaus Neumann takes us on a very exciting tour through the deeps and shallows of Australia's history of migration and asylum policies between 1901 and 1977 and sets out how subsequent administrations in Canberra have dealt with refugees intending to reach the "lucky country." Not only is Neumann's book very timely, given the record numbers of displaced people around the entire globe, but also, by covering the gamut of key global events and domestic stimuli for Australia's more recent refugee policies, his go-to compendium fills a gaping hole in the accessible academic literature.

Against popular belief that Australia is the most soughtafter refuge among the world's displaced people, Neumann shows that for most of the 2oth century, Australia was not a preferred destination for refugees, simply because it was deemed too remote and expensive to reach. More importantly, Australia, which at the time had an even more ethnically homogeneous population than its distant motherland, was not open to people with the "wrong" skin colour or the "wrong" religion. Too robust were the fears "of infiltration by professional trouble makers, whether Jewish terrorists or Communists agents, [who] will arouse the natural suspicion of all who wish to see Australia kept Australian" (93). Even before migration and border control became as sophisticated as it is today, there were many ways to block the entry of unwanted people. With expensive landing fees in placeit would have been useful if this book had contextualized them with current costs - that all migrants, other than a few who were exempt, had to pay upon embarkation, Australia made sure that those who were simply too poor could not enter (although not long ago, public opinion also deemed that being too wealthy was inappropriate for a "deserving" refugee).

Neumann tells of Chinese stowaways, East German ballerinas, KGB spies, and others whose arrival in Australia was not necessarily the end of an enduring venture. One of the most illuminating stories is that of the publicist Walter Stolting. A non-practising Jew from Germany, Stolting fell under the 1935 Nuremberg laws, under which Jewish Germans no longer had the same rights as non-Jewish Germans. In order to escape the Nazis and save his life, he came to Australia, only to be viewed as a potentially pro-German enemy alien and interned in a camp, which later circumscribed his employment options.

Despite the prevailing anti-Jewish sentiment, even after the news about the Holocaust had come through, Australia did agree to take in German and, later on, also Polish Jews (yes, there was a clear hierarchy of the desirability of the persecuted). According to Neumann, the prime motivation was not humanitarian, but rather Australia's urge to keep pace with its peers. Later in the book he presents a similar argument about the slow abolition of the White Australia policy; he considers politicians feared the negative effect it had on Australia's reputation around the globe.

Whereas chapter 1 lays out how Australia attempted to prevent the arrival of refugees, subsequent chapters show how Australia, particularly when there was a labour shortage, slowly, and not without severe setbacks, started to open 
up to refugee populations other than the blond and blueeyed "beautiful Balts," who were assumed the least likely to encounter problems in becoming "ideal 'New Australians." Given that politicians dreamed of a bigger Australia after the Second World War, even though Australian fertility was then below replacement levels and the ennoblement of motherhood (to use the lingo of that time) would prove insufficient to boost population growth and therefore economic development, Australian decision-makers had to change their approach to refugees. With the help of the International Refugee Organisation (IRO), which Neumann denotes as a "child of the Cold War" (99), Australia started looking for people with certain nationalities and professions among the millions of displaced Europeans. The intake of more than 100,000 displaced people in the late 1940 s signalled the end of Australia's exclusive preference for British migrants, but refugees who migrated under the IRO schemes had to work and live as directed, or risk deportation (121). This cherry-picking meant that many maimed survivors of the war and less socially desirable people, such as single mothers and their children, were screened out.

Chapters 3 and 4 detail Australia's different approaches in immigration policies under Menzies and Whitlam to subsequent refugee populations, including the Hungarians who came after the 1956 Uprising and the Czechoslovakians who left after the 1968 Prague Spring, as well as some Russian defectors. Next to those European refugees, at this time Australia began to be confronted with resettlement requests from other refugees, not just those from the Asia-Pacific region, such as the West Papuans, followed a decade later by the East Timorese who rejected the annexation of their homelands by Indonesia, and eventually the Vietnamese after the fall of Saigon, but also substantial refugee flows from political crises in Uganda and Chile. Because there was no consistent asylum policy, these refugee groups faced very different treatment. Some were allowed in but had to pledge to refrain from political activity related to their homelands, while others, such as the West Papuans who had crossed the border into Papua New Guinea (then an Australian colony, which did not become independent until 1975), were not allowed resettlement in Australia.

The last chapter focuses on the domestic challenges that the Fraser government faced after the first arrivals of Vietnamese asylum-seeker boats in Darwin and the rapid public mood-swing from compassion to panic. Under the Fraser administration tens of thousands of people from Indochina were eventually resettled in Australia, yet after the 1977 federal election, in which refugee issues seemed to have played a significant role, Fraser was concerned that popular xenophobic sentiment, spurred on by the media, could get easily out of control. As is widely known, many subsequent Australian prime ministers have not shared any such concern at all.

Reading Neumann's account, one cannot but wonder about the many historical parallels, whether it be the widespread ignorance among administrators of political developments overseas, or the good-character tests inflicted on people randomly, the interpretation of which is usually left to the discretion of bureaucrats. In fact, a primary strength of this book is that it subtly points out the many earlier versions of the punitive excrescences of Australia's current refugee policy, such as the ongoing separation of family members. In much the same way that refugees face negative security assessments from the Australian Security Intelligence Organisation nowadays, suspicious aliens, even as far back as the late 1930s, had to defend their innocence without knowing exactly what organizations like the Commonwealth Investigation Branch was holding against them, because "the government did not reveal the reasons for someone's internment," making it "difficult for the internees to successfully convince the tribunal they were loyal to Australia or would cause no harm if released" (60).

Neumann has done a great job of digging up very insightful facts and figures from the archives, but he has also collected very illustrative stories and anecdotes from refugees and their biographical writings (which would make good follow-up reading too) to show what bureaucratic decisions meant for individuals confronted with them. Neumann refrains from making any moralistic conclusions, preferring to leave this to his readers. Even though it deals with some rather gloomy material, Neumann's account is well written in an easy style and with a hint of irony, which make the book a real page-turner.

Antje Missbach is senior research fellow at Monash University, Melbourne. The author may be contacted at antje.missbach@ monash.edu. 


\title{
Real Queer? Sexual Orientation and Gender Identity Refugees in the Canadian Refugee Apparatus
}

\author{
$\sim$ \\ David A. B. Murray \\ London: Rowman \& Littlefield, 2016, 183 pp.
}

$R$ eal Queer? offers a critical analysis of the Canadian refugee determination system or what David Murray refers to as the "Canadian Refugee Apparatus" (CRA) (9), specifically focusing on the complex ways in which sexual orientation and gender identity (SOGI) refugee claimants become unique targets of state control. The product of an intensive ethnographic study of sogi refugee claimants (primarily from Africa and the Caribbean), refugee support groups, and the Immigration and Refugee Board (IRB) in Toronto, the study provides detailed and critical insights into the politics of the refugee claims-making and adjudication process-as part of a larger state assemblage of surveillance, management and removal of migrants. Across the book's eight chapters, Murray investigates how the CRA-through its range of constituted subjects and relations-anchors a state-sponsored system of truth-making and violent ruling of precarious claimant subjects/populations, based on arbitrary distinctions between $\mathrm{real} / \mathrm{credible}$ and fake/bogus sogI refugee claimants.

Murray situates this investigation in relation to the state's homonationalist discourse, or what he terms "the queer migration to liberation nation narrative" (3), whereby Canada is discursively projected as a safe haven for queers escaping persecution in their countries of origin. This narrative, Murray argues, is crucially hinged on the "newish migrant identity category" (5) of the sogi refugee claimant, who is folded into national-normativity by the CRA through a discourse of "inaugural homonationalism" (53). Moreover, Murray demonstrates how the homonationalist imperative works by requiring documentary evidence from various actors, including soGI refugee claimants, brokering organizational bodies, and the IRB. These various forms of evidence align claimants with Western-centric constructs of sogI, constituting the refugee claimant as a potential citizen. For example, chapters 2 and 4 focus on the Personal Information Form (PIF) and letters from sogI refugee support groups respectively-documents that mediate and are key to establishing the credibility of sogi refugee claimants. Both chapters demonstrate the hailing force of homonationalism as claimants learn how to use the PIF to make their stories intelligible to the IRB and as support groups establish their own credibility as "document brokers" (83) with the power to assist the IRB's powers of interrogation and ruling. Drawing on the work of Miriam Ticktin, ${ }^{1}$ Murray argues that these "regimes of care and their documents" (83) enable homonationalism and enact various forms of surveillance that have violent and exclusionary effects.

Similarly, chapter 6 focuses critically on expert reports and national documentation packages (governmental, non-governmental, and media reports), as a "bureaucratic archive of sexuality" (119) that underwrites the CRA's homonationalist project. Murray queers this archive, arguing that these documents problematically reproduce countries in the Global South as repressive, based on the presumption of "cross-cultural intelligibility" (119) of gender and sexuality. His analysis does not necessarily suggest that claimants' countries of origin are tolerant of diverse sogI, but cautions "against assuming transnationally uniform meanings of socio-sexual identity terms like 'gay,' 'lesbian' and 'transgender"' (125). Furthermore, Murray shows how even the misreadings of his own work by the IRB serve to transform/straighten complex scholarly analyses into essentializing evidence about persecution or tolerance-as the only two qualifiers through which the claimant's credibility can be assessed. We also see how the CRA's homonationalist discourse hinges on the re-mobilization of colonial scripts, which naturalize predominantly racialized nation states of the Global South as anti-queer and intolerant.

Chapters 4 and 5 deepen this argument by highlighting the interconnections between discourse and affect in constructing and adjudicating the distinction between real and bogus refugee claimants. Through analysis of participant observation data of refugee claimants' hearings, discussions with Refugee Determination Board (RDB) members, and a publication by a former director of the IRB, Murray demonstrates how RDB members employ a certain "calculus" (110) of affective and linguistic disciplining to determine a claimant's credibility. Through his analysis of pauses, silences, disciplinary comments, sighs, and other non-verbal cues, Murray argues persuasively that "emotional and sensorial assessments" (113) presume a universal understanding of emotional registers such as love, loss, and trauma. Especially in chapter 5 , we glimpse the sogi refugee claimant as a particular kind of homonationalist subject, who coheres around very specific registrations of potentiality and precarity and who is fetishized within the ritual of the hearing.

While the book demonstrates the exceptional hailing force of the CRA's homonationalist project, it also offers critical insight into the "adaptive agency" (9) of refugee claimants as they navigate the determination process. These
(C) Author(s), 2016. This open-access work is licensed under a Creative Commons Attribution-NonCommercial 4.0 International license.
Cette oeuvre en libre accès fait l'object d'une licence Creative Commons Attribution-NonCommercial 4.0 International. 
sites of agency demonstrate that while homonationalism is pervasive and proliferating, it is never complete. Chapter 3, "How to Be Gay (Refugee Version)," is quite instructive in this regard. Analyzing the rehearsals for a public play-which begins with a complex narrative and aesthetic but, through several disciplinary rehearsals, ends with the straightened speech and conduct of the "real" gay character-Murray carefully illustrates "how a performance of a gay male self that does not reflect the experiences and privileges of a hegemonic gay cultural identity . . . renders the performer suspect, that is, not 'really' gay" (76). As such, the chapter highlights how refugee claimants attempt to frustrate the encompassing and coercive force of the statebased determination process-and thus its protocols of intelligibility about sexuality and gender-while realizing that they remain constrained within an epistemic border zone that heightens their precarity. Further challenges to the CRA's homonationalist discourse can be found in Murray's findings that claimants have complicated relationships to Western conceptions of gender and sexuality, have complex stories about their decisions to file refugee claims in Canada, and have complex affective orientations toward their countries of origin and Canada. These findings suggest that claimant-subjects are never completely folded into homonationalist discourse.
Overall, the book makes a solid contribution to the interrelated fields of queer migration and sogi refugee studies in the Canadian context, especially so in its focus on how the figure of the sogI refugee claimant occupies an ambivalent relationship to homonationalism. One central question it raises is how we conceptualize the agency of "the claimant"-as a subject who is stranded within the border zone produced by the CRA, especially if this subject is at once a site of "incommensurability" (57) and "potentiality" (45)? This question is central to understanding the question mark in the book's title, as it pushes us to think critically about what it means for claimants to simultaneously speak within, outside of, and against the hegemonic framework of intelligibility about gender and sexuality.

Note

1 M. Ticktin, Casualties of Care: Immigration and the Politics of Humanitarianism in France (Berkeley: University of California Press, 2011).

Amar Wahab is assistant professor in gender and sexuality at York University. The author may be contacted at awahab@ yorku.ca.

\title{
Navigating a River by Its Bends: A Comparison of Cambodian Remigration
}

\author{
$\infty$ \\ Gea Wijers \\ Amsterdam: vu University Press, 2013, 197 pp.
}

$N$ Tavigating a River by Its Bends is the book version of Gea Wijers's doctoral dissertation. It comprises a collection of authored or co-authored articles and book chapters based on multi-sited fieldwork conducted between 2010 and 2011 in France, the United States, and Cambodia. The study examines the life trajectories of firstgeneration Cambodian French and Cambodian American returnees and explores how they made use of their special forms of social capital when engaging in "institutional entrepreneurism" upon return to Cambodia. The study revolves around those Cambodians who arrived in America or France before 1979 and who subsequently returned to Cambodia with hopes of helping to rebuild their country after the signing of the Paris Peace Accords in 1991.

Dr. Wijers also asked in what ways refugee settlement policies in Long Beach, California, and Lyon, France, affected the abilities of these Cambodians to adapt both to life in exile and life upon return to their homeland. Of particular interest for the study was the question of how transnational networks and experiences from exile might influence returnees' chances of establishing themselves back in Cambodia.

The interviews were analyzed using several key concepts such as that of "embeddedness," by which Wijers means the process by which legitimacy is created in social networks. This notion underlies the author's interest in the returnees' transnational webs of relations and their ability to mobilize social capital upon return to Cambodia.

The author presents a valuable historical overview of the various groups of refugees that have spent large parts of their lives in either France or the United States. She also describes how the social, cultural, and political climate of each country at the time of resettlement and the different modes of reception have influenced how these groups have 
evolved and adapted. She notes how these differences are then played out in the way returnees from each country have tended to be perceived in Cambodia and how, against this background, they have tried to navigate the social landscape upon return to their native country.

Wijers notes how Cambodian American returnees have tended not to reintegrate into the entrenched patronclientelism that endures in Cambodia and that they have often become active in civil society advocacy organizations, thereby positioning themselves as critics of, rather than participants in, Cambodian norms and networks. She contrasts this with the Cambodian French returnees' preference for trying to influence the system from within after they returned, often by accepting positions in government or the civil service, usually as supporters or members of the royalist opposition party FUNCINPEC.

Wijers concludes that the social capital acquired overseas by Cambodians returning from the United States or France is not an unmitigated bonus for gaining legitimacy back in their homeland. She notes that although the knowledge, experience, and social networks returnees gained from living in other countries offer some advantages, these people also struggle for recognition as "real Khmers" back in Cambodia. Without a strong foothold in local patron-client networks, their loyalties may be called into question. Wijers observes that, over time, many therefore find themselves forced to demonstrate allegiances to power-holders in order to secure their own social survival.

Further, the author points out that the geopolitical position of the returnees' respective host countries also affects how they tended to be viewed upon return to Cambodia. If they failed to maintain their Khmer language skills while away, this could further limit their opportunities for reintegrating.

There are many interesting and insightful passages in this book. The information is clearly presented, and it is easy to follow the author's arguments. Wijers more than adequately fulfils her humble ambition of "filling a gap" in research on this topic and, in fact, makes original contributions to our knowledge about the kinds of problems that returneesnot only to Cambodia-face after spending years in other countries.

However, as noted above, this is a doctoral dissertation comprising several published articles loosely drawn together by an introduction and some general concluding remarks. As such, the book contains considerable repetition, some of which is, indeed, verbatim, with several quotations, for instance, recurring in two places in the book. The volume would, therefore, have benefitted from some purposeful revision geared toward eliminating redundant text.

My second concern with this work is about the methodology and use of interview material. After reading the introduction, I was anticipating some reasonably "thick description" of the lives of at least a few of the author's interlocutors. I imagined that there would be one or two more elaborate life stories, or sections of them, included to illustrate the more general points that the book makes about the opportunities and constraints refugees experience in a host country and upon return to their native country. Chapter 5 is the richest in ethnographic data but, overall, it would have strengthened this work considerably to hear more detail about the people themselves and the intricacies of their everyday lives. For instance, the author tells us about the lack of a sense of community among Cambodians living in France; yet there is little ethnographic detail, such as descriptions of the relationships or tensions between individuals or households through work, schooling, kinship connections, and so on. In general, the quotations from interlocutors seem to be mainly opinions or generalizations, which the author sometimes, rather uncritically, accepts as fact, but they give little information about the complexity of these refugees' own personal experience.

Finally, the book's subtitle, "A Comparison of Cambodian Returnees' Contributions to the Transformation of Cambodia," is somewhat misleading. The reader may expect a work focusing on Cambodia's dramatic transformation in recent decades and the ways in which these groups of returnees have helped bring this about. In fact, the book says little about the particular ways in which the country has been transformed under Prime Minister Hun Sen's leadership and, if anything, simply shows that neither of these groups of returnees has been able to exert much influence in the process of creating the Cambodia we see today.

Notwithstanding these reservations, this work is praiseworthy as a piece of original research that enriches our understanding of the factors influencing the possibilities as well as limitations that refugees may experience upon returning to their homeland.

Alexandra Kent is associate professor of social anthropology at the Nordic Institute of Asian Studies, Copenhagen. The authormay be contacted at alixkent@yahoo.co.uk. 